\title{
Task 21 - Development of Systems Engineering Applications for Decontamination and Decommissioning Activities
}

\author{
Semi-Annual Report \\ April 1 - September 30, 1998 \\ By \\ Thomas A. Erickson \\ RECEIVED \\ MAR 081999 \\ OSTI
}

Work Performed Under Contract No.: DE-FC21-94MC31388

For

U.S. Department of Energy

Office of Fossil Energy

Federal Energy Technology Center

P.O. Box 880

Morgantown, West Virginia 26507-0880

By

Energy \& Environmental Research Center

University of North Dakota

P. O. Box 9018

Grand Forks, North Dakota 58202-9018 


\section{DISCLAIMER}

Portions of this document may be illegible in electronic image products. Images are produced from the best available original document. 


\section{TABLE OF CONTENTS}

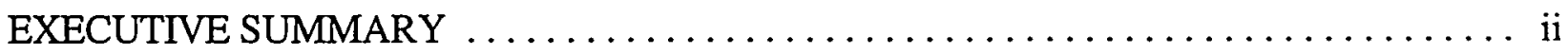

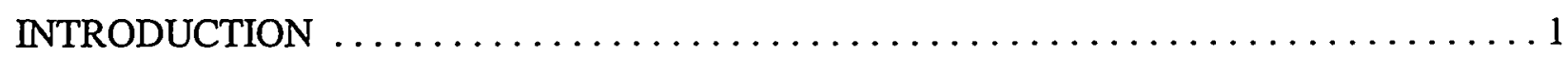

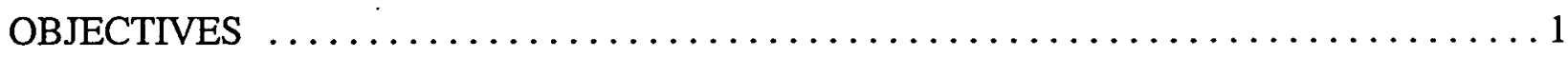

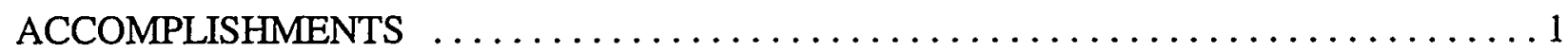

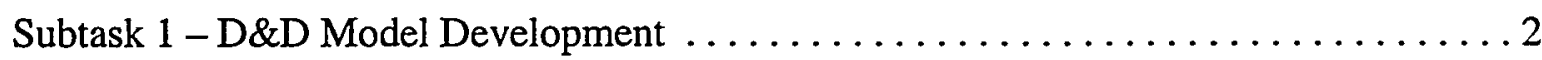

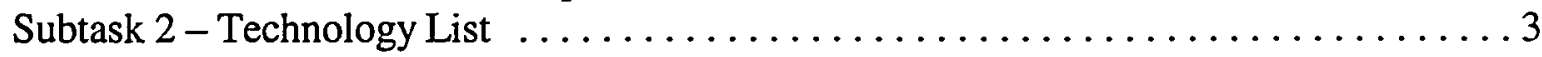

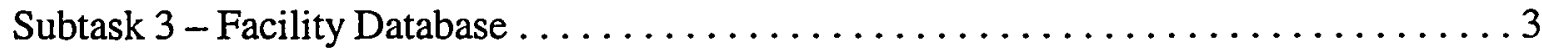

Subtask 4 - Incorporation into a User Model $\ldots \ldots \ldots \ldots \ldots \ldots \ldots \ldots \ldots \ldots$

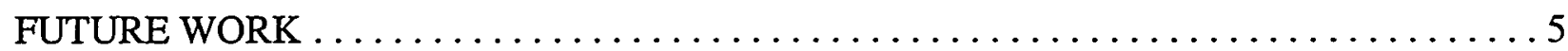

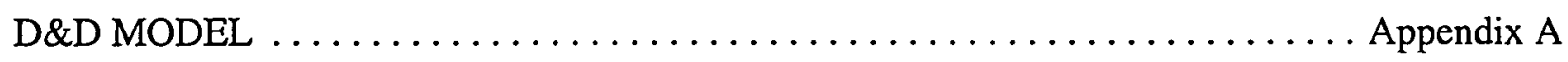

D\&D TECHNOLOGIES ASSESSMENT: TECHNOLOGY LIST $\ldots \ldots \ldots \ldots$ Appendix B

FACIITIES DATABASE STRUCTURE $\ldots \ldots \ldots \ldots \ldots \ldots \ldots \ldots \ldots$ Appendix $C$

COMPARISON OF MODEL EQUATIONS AND DATABASE VARIABLES .... Appendix D

COST AND SECONDARY WASTE INFORMATION $\ldots \ldots \ldots \ldots \ldots \ldots \ldots$ Appendix E 


\section{TASK 21 - DEVELOPMENT OF SYSTEMS ENGINEERING APPLICATIONS FOR DECONTAMINATION AND DECOMMISSIONING ACTIVITIES}

\section{INTRODUCTION}

Over the last 20 years, the use of systems engineering has been recognized as a powerful tool to aid industry in developing better products in shorter periods of time. More recently, systems engineering has been recognized for its ability to help in developing programs and projects much broader than a single technology. One of the major strengths of systems engineering is its ability to bring together industrial partners, stakeholders, and the public interest.

Within this project, a systems engineering approach is being applied to optimally identify and link potential decontamination and decommissioning (D\&D) technologies with the needs of the sites. The key is to fully understand the cost and waste generation factors for each technology within each scenario (facility, group of facilities, site, Y).

\section{OBJECTIVES}

The objectives of this task are to:

- Develop a model (paper) to estimate the cost and waste generation of cleanup within the Environmental Management (EM) complex.

- Identify technologies applicable to D\&D operations within the EM complex.

- Develop a database of facility information as linked to project baseline summaries (PBSs).

The above objectives are carried out through the following four subtasks: Subtask 1D\&D Model Development, Subtask 2 - Technology List, Subtask 3 - Facility Database, and Subtask 4 - Incorporation into a User Model.

\section{ACCOMPLISHMENTS}

A significant amount of work has been accomplished within the last six months as discussed below by subtask. 


\section{Subtask 1 - D\&D Model Development}

A model was developed to encompass all aspects of D\&D operations within the EM complex. The D\&D model developed is shown in Appendix A.

The model includes the following stages of D\&D:

- Precharacterization

- Decontamination

- Cutting and sizing

- Postcharacterization

- Demolition

- Disposal

- Surveillance and maintenance

- Worker safety and health

- Temporary utilities

Each of the above stages are further divided into material types and surface types shown below:

- Material types

- Concrete

- Metal

- Wood

- Lead brick

- Asbestos

- Transite

- Surface types

- Floors

- Walls

- Ceilings

- Structural steel

- Tubing

- Piping

- Pipe lagging

- Glove boxes

The model developed is extremely complex in application but simplistic in design. Many of the operations are simplified to allow the minimal amount of information necessary to perform the calculations.

The paper model was provided to Alias Group Inc. for inclusion into its overall EM modeling efforts as discussed in Subtask 4. 


\section{Subtask 2 - Technology List}

The ability to predict the costs and waste generation rates for cleanup of the EM complex depends upon the technologies available for application to the cleanup effort. Significant emphasis has been placed by the Office of Science \& Technology on the development of new technologies and seeking out existing technologies for application. In addition to identifying the technologies, cost and performance information is necessary to allow accurate predictions for a given technology.

Version 2.1 of the technology list was provided to the U.S. Department of Energy (DOE) in September 1998. Version 2.1 as submitted can be found in Appendix B and is summarized below.

A total of 533 technologies have been identified for use in EM D\&D activities, with 126 considered alternative (innovative) and 407 considered baseline. To date, only the innovative technology status reports (ITSRs) generated to summarize the results of technology evaluations within the D\&D focus area (DDFA) large-scale demonstration project (LSDP) program appear to provide reasonable cost data. The work breakdown structure (WBS) of the ITSRs is a structured methodology that attempts to include the cost for all facets of utilizing a technology from mobilization to operation, maintenance, decontamination, and eventual demobilization. Even the costs of human factors such as productivity loss and personal protective equipment (PPE), set up of support equipment, and disposal of PPE are included.

Data for determination of fixed and variable costs as well as secondary waste generation (where applicable) were found in 44 ITSRs prepared for DDFA-sponsored LSDPs. Among these, however, only 22 covered technologies that are suitable for use in the current version of the D\&D model.

\section{Subtask 3 - Facility Database}

The facility database houses the information related to the sites, facilities, and PBSs. In addition, it houses all of the technology information generated in Subtask 2. Work within this subtask is divided between searching out the necessary information and developing a relational database that can be accessed by the model coder (Alias Group Inc.).

Locating information related to facilities, sites, and PBSs has proven to be extremely difficult. There is no single site that houses all of the information necessary to make accurate predictions, and, to date, much of the information necessary to operate the model across the entire EM complex is lacking. When essential data cannot be found, engineering estimates are developed to fill the information void. The following summarizes the information within the facilities database.

Presently, there are 76 PBSs encompassing deactivation and decommissioning activities at the DOE EM sites. Among the 76 D\&D PBSs, only 35 entail facility D\&D, while 39 of the PBSs do not list a single facility or release site. There are 1893 properties classified as facilities, 2298 

It is worth noting that there were many matches where the facility description given for a PBS matched verbatim the property description given in the FIMS. More commonly though, matches were made using identification codes. It was apparent that many buildings had at least one alias or their mission may have changed between population of the FIMS and generation of the PBSs.

The database structure to hold all of the facility information is shown in Appendix C. The structure is extremely complex to allow various links to be formed between the technologies, needs, PBSs, and facilities. The comparison of variable names within the model and the field names in the database is shown in Appendix D.

\section{Subtask 4 - Incorporation into a User Model}

As mentioned previously, the paper model and facility database have been provided to Alias Group Inc. for inclusion into its overall EM complex model. It is noted that the user interface necessary to operate the model will be extremely complex to allow the user full control of the model. Upon completion, the computer model will allow the user to match technologies and needs, estimate the costs and wastes associated within a given scenario, plan deployment opportunities, and optimize the overall planning of D\&D activities across the EM complex.

\section{FUTURE WORK}

The following activities are expected to continue through the next six months of this task:

- D\&D Model Development

- Based on user feedback, modify and enhance the model

- Add in additional model features as requested, such as work plan acceleration and capping and monitoring

- Technology List

- Develop cost and performance information for the database as new ITSRs are completed.

- Add in new technologies as they are identified

- Add in international technologies

- Facility Database

- Continue tracking information about facilities and their relationships to the PBSs

- Update the database with new needs and PBS information as it becomes available

- Perform database analyses to aid in the linkage and work package exercises

- Incorporation into a User Model

- Provide all updates to Alias Group Inc. for inclusion into the computer model

- Participate in meetings to present the model and related information 
APPENDIX A

\section{D\&D MODEL}




\section{TABLE OF CONTENTS}

\begin{tabular}{|c|c|}
\hline .0 & asic Model Information \\
\hline & Concrete \\
\hline & 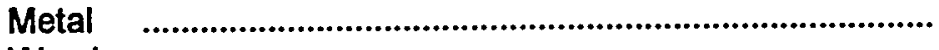 \\
\hline .0 & 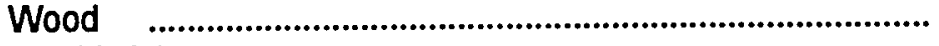 \\
\hline & . \\
\hline & (1) \\
\hline & 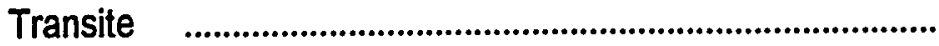 \\
\hline & Surveillance \& Maintenance \\
\hline & Safety \& Health \\
\hline & ry Utilities \\
\hline
\end{tabular}


LEGEND

The following convention is used to differentiate between variables used in the D\&D Model equations.

Function of facility type

Function of facility

Specific to technology 


\subsection{Basic Model Information}

\subsection{General}

a) Area Total Wall

$=\sqrt{\text { Size }} \times$ Height $\times 4 \times(1+$ Wall Multiplier $)$

b) AreaV Wall

$=\sqrt{\text { Size }} \times$ Height $\times 4 \times(1+$ Wall Multiplier $/ 2))$

Reflects area of only one side of a common wall

c) Area Total Ceiling

= Size

d) Area Total Floor

= Size

\subsection{Structural Steel}

a) Length Small Structural Steel

$=\sqrt{\text { Size }} \times(\sqrt{\text { Size/Small Structural Steel Factor }}+1)$

b) Length Large Structural Steel

$=(\sqrt{\text { Size }} /$ Large Structural Steel Factor +1$) \times(\sqrt{\text { Size }} /(3 \times$ Large Structural Steel Factor $)+1) \times$ Height

\subsection{Tubing}

a) Length Tubing

$=$ Size $\times$ Tubing Factor

\section{$1.4 \quad$ Small Piping}

a) Length Small Piping

$=$ Size $\times$ Small Pipe Factor

\subsection{Large Piping}

a) Length Large Piping

$=$ Size $\times$ Large Pipe Factor

\subsection{Ducting}

a) Length Ducting

$$
=\text { Size } \times \text { Ducting Factor }
$$

\subsection{Lead Brick}

a) Number Lead Bricks 
$=$ Size $\times$ Lead Brick Factor

\subsection{Glove Boxes}

a) Number Glove Boxes

$=$ @round(Size $\times$ Box Factor)

\subsection{Asbestos - Pipe Lagging and Other}

a) Length Small Pipe Lagging

$=$ Length Small Piping $\times$ Small Pipe Lagaing Factor

b) Length Large Pipe Lagging

$=$ Length Large Piping $\times$ Large Pipe Lagging Factor

c) Area Insulation

$=\sqrt{\text { Size }} \times 4 \times$ Height

\subsection{Transite}

a) Area Transite

$=$ Size $\times$ Transite Factor

\subsection{CONCRETE}

\section{$2.1 \quad$ Basic Information}

\subsubsection{Walls}

a) Area Concrete Wall

$=$ Area Total Wall $\times \%$ area concrete wall

b) AreaV Concrete Wall

$=$ AreaV Wall $\times \%$ area concrete wall

c) Area HR Thin Wall

$=$ Area Concrete Wall $\times \%$ area HR Thin Wall

d) AreaV HR Thin Wall

$=$ AreaV Concrete Wall $\times \%$ area HR Thin Wall

e) Area HR Thick Wall

$=$ Area Concrete Wall $\times \%$ area HR Thick Wall

f) AreaV HR Thick Wall

$=$ AreaV Concrete Wall $\times \%$ area HR Thick Wall

g) Area MR Thin Wall

= Area Concrete Wall $\times \%$ area MR Thin Wall

h) AreaV MR Thin Wall 
$=$ AreaV Concrete Wall $\times \%$ area MR Thin Wall

i) Area MR Thick Wall

$=$ Area Concrete Wall $\times \%$ area MR Thick Wall

j) AreaV MR Thick Wall

$=$ AreaV Concrete Wall $\times \%$ area MR Thick Wall

k) Area UnR Thin Wall

$=$ Area Concrete Wall $\times \%$ area UnR Thin Wall

I) AreaV UnR Thin Wall

$=$ AreaV Concrete Wall $\times \%$ area UnR Thin Wall

m) Area UnR Thick Wall

$=$ Area Concrete Wall $\times \%$ area UnR Thick Wall

n) AreaV UnR Thick Wall

$=$ AreaV Concrete Wall $\times \%$ area UnR Thick Wall

\subsubsection{Ceilings}

a) Area Concrete Ceiling

$=$ Area Total Ceiling $\times \%$ area concrete ceiling

b) Area HR Thin Ceiling

$=$ Area Concrete Ceiling $\times \%$ area HR Thin ceiling

c) Area HR Thick Ceiling

$=$ Area Concrete Ceiling $\times \%$ area HR Thick ceiling

d) Area MR Thin Ceiling

$=$ Area Concrete Ceiling $\times \%$ area MR Thin Ceiling

e) Area MR Thick Ceiling

$=$ Area Concrete Ceiling $\times \%$ area MR Thick Ceiling

f) Area UnR Thin Ceiling

$=$ Area Concrete Ceiling $\times \%$ area UnR Thin Ceiling

g) Area UnR Thick Ceiling

$=$ Area Concrete Ceiling $\times \%$ area UnR Thick Ceiling

\subsubsection{Floors}

a) Area Concrete Floor

$=$ Area Total Floor $\times \%$ area concrete floor

b) Area HR Thin Floor

$=$ Area Concrete Floor $\times \%$ area HR Thin Floor

c) Area HR Thick Floor

$=$ Area Concrete Floor $\times \%$ area HR Thick Floor 
d) Area MR Thin Floor

= Area Concrete Floor $\times \%$ area MR Thin Floor

e) Area MR Thick Floor

$=$ Area Concrete Floor $\times \%$ area MR Thick Floor

f) Area UnR Thin Floor

$=$ Area Concrete Floor $\times \%$ area UnR Thin Floor

g) Area UnR Thick Floor

$=$ Area Concrete Floor $\times \%$ area UnR Thick Floor

\subsection{Pre-Characterization}

\subsubsection{Walls}

Perform for each contaminant (contaminant specific variables are: contaminant factor)

Rad

Organic

Inorganic

Mercury

a) Cost Concrete Wall Pre-Char.

$=($ Cost Avg $\times$ Area Concrete Wall $\times \%$ area contaminated walls $\times$ contaminant factor $)+$ deployment cost

\subsubsection{Ceilings}

Perform for each contaminant (contaminant specific variables are: contaminant factor)

Rad

Organic Inorganic

Mercury

a) Cost Concrete Ceiling Pre-Char.

$=($ Cost Avg $\times$ Area Concrete Ceiling $\times \%$ area contaminated ceilings $\times$ contaminant factor $)+$ deployment cost

\subsubsection{Floors}

Perform for each contaminant (contaminant specific variables are: contaminant factor)

Rad

Organic

Inorganic

Mercury

a) Cost Concrete Floor Pre-Char.

$=($ Cost Avg $\times$ Area Concrete Floor $\times \%$ area contaminated floors $\times$ contaminant factor $)+$ deployment cost

\subsection{Decontamination}




\subsubsection{Walls}

Perform a to e for each contaminant (contaminant specific variables are: depth of contamination walls\&ceilings, contaminant factor)

Rad

Organic

Inorganic

Mercury

a) Number Passes Walls

= @trunc(depth contamination walls\&ceilings / thickness removed per pass) + 1

b) Depth Concrete Wall Removed

$=$ Number of Passes Walls $\times$ thickness removed per pass

c) Weight Primary Waste Concrete Wall Decon

$=$ Area Concrete Wall $\times \%$ area contaminated walls $\times$ contaminant factor $\times$ depth concrete wall removed $x$ concrete density

d) Weight Secondary Waste Concrete Wall Decon

$=$ Area Concrete Wall $\times \%$ area contaminated walls $\times$ contaminant factor $\times$ number passes walls $\times$ (sec. waste gen. rate / production rate)

e) Cost Concrete Wall Decon

$=($ Area Concrete Wall $\times \%$ area contaminated walls $\times$ contaminant factor $\times$ number passes walls $\times$ Cost Avg) + deployment cost

f) Average depth concrete wall removed

$=$ sum [depth concrete wall removed (contaminant) $\times$ contaminant factor ]

\subsubsection{Ceilings}

Perform a to e or each contaminant (contaminant specific variables are: depth of contamination walls\&ceilings, contaminant factor)

\section{Rad}

Organic

Inorganic

Mercury

a) Number Passes Ceilings

= @trunc(depth contamination walls\&ceilings / thickness removed per pass) + 1

b) Depth Concrete Ceiling Removed

$=$ Number Passes Ceilings $\times$ thickness removed per pass

c) Weight Primary Waste Concrete Ceiling Decon

$=$ Area Concrete Ceiling $\times \%$ area contaminated ceilings $\times$ contaminant factor $\times$ depth

concrete ceiling removed $\times$ concrete density

d) Weight Secondary Waste Concrete Ceiling decon

$=$ Area Concrete Ceiling $\times \%$ area contaminated ceilings $\times$ contaminant factor $\times$ number passes ceilings $\times$ (sec. waste gen. rate / production rate)

e) Cost Concrete Ceiling Decon 
$=$ (Area Concrete Ceiling $\times \%$ area contaminated ceilings $\times$ contaminant factor $\times$ number passes ceilings $\times$ Cost Avg) + deployment cost

f) Average depth concrete ceiling removed

$=$ sum [depth concrete ceiling removed (contaminant) $\times$ contaminant factor ]

\subsubsection{Floors}

Perform a to e for each contaminant (contaminant specific variables are: depth of contamination floors, contaminant factor)

Rad

Organic

Inorganic

Mercury

a) Number Passes Floors

= @trunc(depth of contamination floors / thickness removed per pass) + 1

b) Depth Concrete Floor Removed

$=$ Number Passes Floors $\times$ thickness removed per pass

c) Weight Primary Waste Concrete Floor Decon

$=$ Area Concrete Floor $\times \%$ area contaminated floors $\times$ contaminant factor $\times$ depth concrete floor removed $x$ concrete density

d) Weight Secondary Waste Concrete Floor Decon

$=$ Area Concrete Floor $\times \%$ area contaminated floors $\times$ contaminant factor $\times$ number passes floors $\times$ (sec. waste gen. rate / production rate)

e) Cost Concrete Floor Decon

$=$ (Area Concrete Floor $\times \%$ area contaminated floors $\times$ contaminant factor $\times$ number passes floors $\times$ Cost Avg) + deployment cost

f) Average depth concrete floor removed

$=$ sum [depth concrete floor removed (contaminant) $\times$ contaminant factor]

\subsection{Post-Characterization}

\subsubsection{Walls}

Perform for each contaminant (contaminant specific variables are: contaminant factor)

Rad

Organic

Inorganic

Mercury

a) Cost Concrete Wall Post-Char.

$=($ Cost Avg $\times$ Area Concrete Wall $\times \%$ area contaminated walls $\times$ contaminant factor $)+$ deployment cost

\subsubsection{Ceilings}

Perform for each contaminant (contaminant specific variables are: contaminant factor)

Rad

Organic 
Inorganic

Mercury

a) Cost Concrete Ceiling Post-Char.

$=($ Cost Avg $\times$ Area Concrete Ceiling $\times \%$ area contaminated ceilings $\times$ contaminant factor $)+$ deployment cost

\subsubsection{Floors}

Perform for each contaminant (contaminant specific variables are: contaminant factor)

Rad

Organic

Inorganic

Mercury

a) Cost Concrete Floor Post-Char.

$=($ Cost Avg $\times$ Area Concrete Floor $\times \%$ area contaminated floors $\times$ contaminant factor $)+$ deployment cost

\subsection{Cutting/Sizing/Demolition}

\subsubsection{Walls}

a) Cost Concrete Wall Hot Spot Removal (for rad only)

$=$ (Area HR Thin Wall $\times \%$ area contaminated walls $\times$ contaminant factor $\times \%$ hot spots walls $\times$ Cost Avg $\times 16+$ deployment cost) +

(Area HR Thick Wall $\times \%$ area contaminated walls $\times$ contaminant factor $\times \%$ hot spots walls $\times$ Cost Avg $\times 33.6+$ deployment cost +

(Area MR Thin Wall $\times \%$ area contaminated walls $\times$ contaminant factor $\times \%$ hot spots walls $\times$ Cost Avg $\times 12+$ deployment cost) +

(Area MR Thick Wall $\times \%$ area contaminated walls $\times$ contaminant factor $\times \%$ hot spots walls $\times$ Cost Avg $\times 25.6+$ deployment cost +

(Area UnR Thin Wall $\times \%$ area contaminated walls $\times$ contaminant factor $\times \%$ hot spots walls $\times$ Cost Avg $\times 8+$ deployment cost +

(Area UnR Thick Wall $\times \%$ area contaminated walls $\times$ contaminant factor $\times \%$ hot spots walls $\times$ Cost Avg $\times 16.8+$ deployment cost)

b) Cost Concrete Wall Demolition

$=(($ AreaV $H R$ Thin Wall $\times(1-(\%$ area contaminated walls $\times \%$ hot spots walls $\times$ contaminant factor) )) $\times$ Cost Avg $\times 2+$ deployment cost +

((AreaV HR Thick Wall $\times(1-(\%$ area contaminated walls $\times \%$ hot spots walls $\times$ contaminant factor))) $\times$ Cost Avg $\times 6+$ deployment cost +

(AreaV MR Thin Wall $\times(1-(\%$ area contaminated walls $\times \%$ hot spots walls $\times$ contaminant factor))) $\times$ Cost Avg $\times 1.5+$ deployment cost $)+$

((AreaV MR Thick Wall $\times(1-(\%$ area contaminated walls $\times \%$ hot spots walls $\times$ contaminant factor))) $\times$ Cost Avg $\times 4.5+$ deployment cost $)+$

((AreaV UnR Thin Wall $\times(1-(\%$ area contaminated walls $\times \%$ hot spots walls $\times$ contaminant factor))) $\times$ Cost Avg $\times 1+$ deployment cost $)+$

((AreaV UnR Thick Wall $\times((1-(\%$ area contaminated walls $\times \%$ hot spots walls $\times$ contaminant factor))) $\times$ Cost Avg $\times 3+$ deployment cost)

\subsubsection{Ceilings}


a) Cost Concrete Ceiling Hot Spot Removal (rad only)

$=($ Area HR Thin Ceiling $\times \%$ area contaminated ceilings $\times$ contaminant factor $\times \%$ hot spots ceilings $\times$ Cost Avg $\times 16+$ deployment cost) +

(Area HR Thick Ceiling $\times \%$ area contaminated ceilings $\times$ contaminant factor $\times \%$ hot spots ceilings $\times$ Cost Avg $\times 33.6+$ deployment cost +

(Area MR Thin Ceiling $\times \%$ area contaminated ceilings $\times$ contaminant factor $\times \%$ hot spots ceilings $\times$ Cost Avg $\times 12+$ deployment cost +

(Area MR Thick Ceiling $\times \%$ area contaminated ceilings $\times$ contaminant factor $\times \%$ hot spots ceilings $\times$ Cost Avg $\times 25.6+$ deployment cost) +

(Area UnR Thin Ceiling $\times \%$ area contaminated ceilings $\times$ contaminant factor $\times \%$ hot spots ceilings $\times$ Cost Avg $\times 8+$ deployment cost) +

(Area UnR Thick Ceiling $\times \%$ area contaminated ceilings $\times$ contaminant factor $\times \%$ hot spots ceilings $\times$ Cost Avg $\times 16.8+$ deployment cost)

b) Cost Concrete Ceiling Demolition

$=(($ Area HR Thin Ceiling $\times(1-(\%$ area contaminated ceilings $\times \%$ hot spots ceilings $\times$ contaminant factor))) $\times$ Cost Avg $\times 2+$ deployment cost $)+$

((Area HR Thick Ceiling $\times(1-(\%$ area contaminated ceilings $\times \%$ hot spots ceilings $\times$ contaminant factor))) $\times$ Cost Avg $\times 6+$ deployment cost +

((Area MR Thin Ceiling $\times(1-(\%$ area contaminated ceilings $\times \%$ hot spots ceilings $\times$ contaminant factor) )) $\times$ Cost Avg $\times 1.5+$ deployment cost $)+$

((Area MR Thick Ceiling $\times(1-(\%$ area contaminated ceilings $\times \%$ hot spots ceilings $\times$ contaminant factor) )) $\times$ Cost Avg $\times 4.5+$ deployment cost $)+$

((Area UnR Thin Ceiling $\times(1$ - (\% area contaminated ceilings $\times \%$ hot spots ceilings $\times$ contaminant factor) )) $\times$ Cost Avg $\times 1+$ deployment cost $)+$

(Area UnR Thick Ceiling $\times((1-(\%$ area contaminated ceilings $\times \%$ hot spots ceilings $\times$ contaminant factor))) $\times$ Cost Avg $\times 3+$ deployment cost)

\subsubsection{Floors}

a) Cost Concrete Floor Hot Spot Removal (rad only)

$=($ Area HR Thin Floors $\times \%$ area contaminated floors $\times$ contaminant factor $\times \%$ hot spots

floors $\times$ Cost Avg $\times 16+$ deployment cost) +

(Area HR Thick Floors $\times \%$ area contaminated floors $\times$ contaminant factor $\times \%$ hot spots floors $\times$ Cost Avg $\times 33.6+$ deployment cost +

(Area MR Thin Floors $\times \%$ area contaminated floors $\times$ contaminant factor $\times \%$ hot spots

floors $\times$ Cost Avg $\times 12+$ deployment cost) +

(Area MR Thick Floors $\times \%$ area contaminated floors $\times$ contaminant factor $\times \%$ hot spots

floors $\times$ Cost Avg $\times 25.6+$ deployment cost) +

(Area UnR Thin Floors $\times \%$ area contaminated floors $\times$ contaminant factor $\times \%$ hot spots floors $\times$ Cost Avg $\times 8+$ deployment cost +

(Area UnR Thick Floors $\times \%$ area contaminated floors $\times$ contaminant factor $\times \%$ hot spots

floors $\times$ Cost Avg $\times 16.8+$ deployment cost)

b) Cost Concrete Floor Demolition

$=(($ Area HR Thin Floor $\times(1-(\%$ area contaminated floors $\times \%$ hot spots floors $\times$

contaminant factor $))) \times$ Cost Avg $\times 2+$ deployment cost $)+$

((Area HR Thick Floor $\times(1-(\%$ area contaminated floors $\times \%$ hot spots floors $\times$ contaminant factor))) $\times$ Cost Avg $\times 6+$ deployment cost) +

((Area MR Thin Floor $\times(1-(\%$ area contaminated floors $\times \%$ hot spots floors $\times$ contaminant factor))) $\times$ Cost Avg $\times 1.5+$ deployment cost +

((Area MR Thick Floor $\times(1-(\%$ area contaminated floors $\times \%$ hot spots floors $\times$ contaminant factor))) $\times$ Cost Avg $\times 4.5+$ deployment cost + 
((Area UnR Thin Floor $\times(1-(\%$ area contaminated floors $\times \%$ hot spots floors $\times$ contaminant factor) )) $\times$ Cost Avg $\times 1+$ deployment cost +

(Area UnR Thick Floor $\times((1$ - $(\%$ area contaminated floors $\times \%$ hot spots floors $\times$

contaminant factor))) $\times$ Cost Avg $\times 3+$ deployment cost

\subsection{Disposal}

\subsubsection{Walls}

a) Weight Concrete Wall Hot Spots (rad only)

$=(($ AreaV HR Thin Wall $\times$ (thickness HR Thin $-(2 \times$ depth concrete wall removed $)))+$ (AreaV HR Thick Wall $\times$ (thickness HR Thick - $(2 \times$ depth concrete wall removed))) + (AreaV MR Thin Wall $\times$ (thickness MR Thin - $(2 \times$ depth concrete wall removed $)))+$ (AreaV MR Thick Wall $\times$ (thickness MR Thick $-(2 \times$ depth concrete wall removed)) ) + (AreaV UnR Thin Wall $\times$ (thickness UnR Thin $-(2 \times$ depth concrete wall removed)) ) + (AreaV UnR Thick Wall $\times$ (thickness UnR Thick $-(2 \times$ depth concrete wall removed)))) $\times$ ( $\%$ area contaminated walls $\times$ contaminant factor $\times \%$ hot spots walls $\times$ concrete density)

b) Cost Concrete Wall Hot Spot Waste Transport

$=$ weight concrete wall hot spots $\times$ transport cost $(\mathrm{rad}) \times$ distance $(\mathrm{rad})$

c) Cost Concrete Wall Hot Spot Waste Disposal

$=$ weight concrete wall hot spots $\times$ primary waste disposal cost (rad)

d) Weight Free Release Concrete Wall

$=(((($ AreaV HR Thin Wall $\times$ thickness HR Thin $)+$

(AreaV HR Thick Wall $\times$ thickness HR Thick) +

(AreaV MR Thin Wall $\times$ thickness MR Thin) +

(AreaV MR Thick Wall $\times$ thickness MR Thick) +

(AreaV UnR Thin Wall $\times$ thickness UnR Thin) +

(AreaV UnR Thick Wall $\times$ thickness UnR Thick)) -

( $\%$ area contaminated walls $\times$ Area Concrete Wall $\times$ average depth concrete wall removed)) $\times$ concrete density) - weight concrete wall hot spots

e) Cost Free Release Concrete Wall Disposal

$=$ Weight Free Release Concrete Wall $\times$ CD disposal cost

Perform f to i for each contaminant (contaminant specific variables are: transport cost, distance, primary waste disposal cost)

Rad

Organic

Inorganic

Mercury

f) Cost Concrete Wall Decon Primary Waste Transport

$=$ Weight Primary Waste Concrete Wall Decon $\times$ transport cost (contaminant) $\times$ distance (contaminant)

g) Cost Concrete Wall Decon Primary Waste Disposal

$=$ Weight Primary Waste Concrete Wall Decon $\times$ primary waste disposal cost (contaminant)

h) Secondary waste disposed on site. No allowance for contaminated HEPA filters.

i) Cost Concrete Wall Decon Secondary Waste Disposal 
$=$ Weight Secondary Waste Concrete Wall Decon $\times$ sec. . waste disposal cost

\subsubsection{Ceilings}

a) Weight Concrete Ceiling Hot Spots (rad only)

$=(($ Area HR Thin Ceiling $\times$ (thickness HR Thin - depth concrete ceiling removed $))+$ (Area HR Thick Ceiling $\times$ (thickness HR Thick - depth concrete ceiling removed)) + (Area MR Thin Ceiling $\times$ (thickness MR Thin - depth concrete ceiling removed)) + (Area MR Thick Ceiling $\times$ (thickness MR Thick - depth concrete ceiling removed)) + (Area UnR Thin Ceiling $\times$ (thickness UnR Thin - depth concrete ceiling removed)) + (Area UnR Thick Ceiling $\times$ (thickness UnR Thick - depth concrete ceiling removed))) $x$ ( $\%$ area contaminated ceilings $\times$ contaminant factor $\times \%$ hot spots ceilings $\times$ concrete density)

b) Cost Concrete Ceiling Hot Spot Waste Transport

$=$ weight concrete ceiling hot spots $\times$ transport cost $(\mathrm{rad}) \times$ distance $(\mathrm{rad})$

c) Cost Concrete Ceiling Hot Spot Waste Disposal

$=$ weight concrete ceiling hot spots $\times$ primary waste disposal cost $(\mathrm{rad})$

d) Weight Free Release Concrete Ceiling

$=(((($ Area HR Thin Ceiling $\times$ thickness HR Thin $)+$

(Area HR Thick Ceiling $\times$ thickness HR Thick) +

(Area MR Thin Ceiling $\times$ thickness MR Thin) +

(Area MR Thick Ceiling $\times$ thickness MR Thick) +

(Area UnR Thin Ceiling $\times$ thickness UnR Thin) +

(Area UnR Thick Ceiling $\times$ thickness UnR Thick)) -

(\% area contaminated ceilings $\times$ Area Concrete Ceiling $\times$ average depth concrete ceiling removed)) $\times$ concrete density) - weight concrete ceiling hot spots

e) Cost Free Release Concrete Ceiling Disposal

$=$ Weight Free Release Concrete Ceiling $\times$ CD disposal cost

Perform $\mathrm{f}$ to $\mathrm{i}$ for each contaminant (contaminant specific variables are: transport cost, distance, primary waste disposal cost)

Rad

Organic

Inorganic

Mercury

f) Cost Concrete Ceiling Decon Primary Waste Transport $=$ Weight Primary Waste Concrete Ceiling Decon $\times$ transport cost (contaminant) $\times$ distance (contaminant)

g) Cost Concrete Ceiling Decon Primary Waste Disposal

$=$ Weight Primary Waste Concrete Ceiling Decon $\times$ primary waste disposal cost (contaminant)

h) Secondary waste disposed on site. No allowance for contaminated HEPA filters.

i) Cost Concrete Ceiling Decon Secondary Waste Disposal

$=$ Weight Secondary Waste Concrete Ceiling Decon $\times$ sec. waste disposal cost 


\subsubsection{Floors}

a) Weight Concrete Floor Hot Spots (rad only) $=(($ Area HR Thin Floor $x$ (thickness HR Thin - depth concrete floor removed $))+$ (Area HR Thick Floor $\times$ (thickness HR Thick - depth concrete floor removed)) + (Area MR Thin Floor $\times$ (thickness MR Thin - depth concrete floor removed)) + (Area MR Thick Floor $\times$ (thickness MR Thick - depth concrete floor removed)) + (Area UnR Thin Floor $\times$ (thickness UnR Thin - depth concrete floor removed)) + (Area UnR Thick Floor $\times$ (thickness UnR Thick - depth concrete floor removed))) $\times$ ( $\%$ area contaminated floors $\times$ contaminant factor $\times \%$ hot spots floors $\times$ concrete density)

b) Cost Concrete Floor Hot Spot Waste Transport

$=$ weight concrete floor hot spots $\times$ transport cost $(\mathrm{rad}) \times$ distance $(\mathrm{rad})$

c) Cost Concrete Floor Hot Spot Waste Disposal

$=$ weight concrete floor hot spots $\times$ primary waste disposal cost (rad)

d) Weight Free Release Concrete Floor $=(((($ Area HR Thin Floor $\times$ thickness HR Thin $)+$ (Area HR Thick Floor $\times$ thickness HR Thick) + (Area MR Thin Floor $\times$ thickness MR Thin) + (Area MR Thick Floor $\times$ thickness MR Thick) + (Area UnR Thin Floor $\times$ thickness UnR Thin) + (Area UnR Thick Floor $\times$ thickness UnR Thick)) (\% area contaminated floors $\times$ Area Concrete Floor $\times$ average depth concrete floor removed) $) \times$ concrete density) - weight concrete floor hot spots

e) Cost Free Release Concrete Floor Disposal

$=$ Weight Free Release Concrete Floor $\times$ CD disposal cost

Perform $f$ to $i$ for each contaminant (contaminant specific variables are: transport cost, distance, primary waste disposal cost)

Rad

Organic

Inorganic

Mercury

f) Cost Concrete Floor Decon Primary Waste Transport

$=$ Weight Primary Waste Concrete Floor Decon $\times$ transport cost (contaminant) $\times$ distance (contaminant)

g) Cost Concrete Floor Decon Primary Waste Disposal

$=$ Weight Primary Waste Concrete Floor Decon $\times$ primary waste disposal cost (contaminant)

h) Secondary waste disposed on site. No allowance for contaminated HEPA filters.

i) Cost Concrete Floor Decon Secondary Waste Disposal

$=$ Weight Secondary Waste Concrete Floor Decon $\times$ sec. waste disposal cost

\subsection{METAL}

\subsection{Basic Information}

\subsubsection{Walls/Ceilings}



a) Area Metal Wall
$=$ Area Total Wall $\times \%$ area metal wall
b) Area Metal Ceiling
$=$ Area Total Ceiling $\times \%$ area metal ceiling

\subsubsection{Structural Steel}

a) Area Small Structural Steel

$=$ Length Small Structural Steel $\times$ area/length small SS $\quad$ (area/length from reference)

b) Area Large Structural Steel

$=$ Length Large Structural Steel $\times$ area/length large SS $\quad$ (area/length from reference)

c) Weight Small Structural Steel

$=$ Length Small Structural Steel $\times$ weight/length small SS $\quad$ (weight/length from reference)

d) Weight Large Structural Steel

= Length Large Structural Steel $\times$ weight/length large SS (weight/length from reference)

e) Number Cuts Small Structural Steel

= @trunc(Length Small Structural Steel / 2)

f) Number Cuts Large Structural Steel

= @trunc(Length Large Structural Steel / 2)

\subsubsection{Tubing}

a) Area Tubing

$=$ Length Tubing $\times$ area/length $\mathrm{T}$

(outside surface area)

(area/length from reference)

b) Weight Tubing

$=$ Length Tubing $\times$ weight/length $T$

(weight/length from reference)

c) Number Cuts Tubing

= (C)trunc(Length Tubing / 2)

\subsubsection{Small Piping}

a) Area Small Piping Outside

$=$ Length Small Piping $\times$ area/length OSP

(area/length from reference)

b) Area Small Piping Inside

$=$ Length Small Piping $\times$ area/length ISP

(area/length from reference)

c) Weight Small Piping

$=$ Length Small Piping $\times$ weight/length SP $\quad$ (weight/length from reference)

d) Number Cuts Small Piping

= @trunc(Length Small Piping / 2) 


\subsubsection{Large Piping}

a) Area Large Piping Outside

$=$ Length Large Piping $\times$ area/length OLP

(area/length from reference)

b) Area Large Piping Inside

$=$ Length Large Piping $\times$ area/length OLP $\quad$ (area/length from reference)

c) Weight Large Piping

$=$ Length Large Piping $\times$ weight/length LP $\quad$ (weight/length from reference)

d) Number Cuts Large Piping

= @irunc(Length Large Piping / 2)

\subsubsection{Ducting}

a) Area Ducting Inside

$=$ Length Ducting $\times$ area/length ID

(for assumed depth and width)

b) Area Ducting Outside

$=$ Length Ducting $\times$ area/length $O D$

c) Weight Ducting

$=$ Length Ducting $\times$ weightlength $\mathrm{D} \quad$ (from reference for given depth and width)

d) Number Cuts Ducting

= @trunc(Length Ducting / 2)

\subsubsection{Glove Boxes}

a) Area Glove Box Inside

$=$ Number Glove Boxes $\times$ area/box 1 (for assumed depth and width)

b) Area Glove Box Outside

$=$ Number Glove Boxes $\times$ area/box 0

c) Weight Glove Boxes

$=$ Number Glove Boxes $\times$ weight/box $\quad$ (from reference for given depth and width)

\subsection{Pre-Characterization}

\subsubsection{Walls}

Perform for each contaminant (contaminant specific variables are: contaminant factor)

Rad

Organic

Inorganic

Mercury

a) Cost Metal Wall Pre-Char.

$=($ Cost Avg $\times$ Area Metal Wall $\times \%$ area contaminated walls $\times$ contaminant factor $)+$ deployment cost 


\subsubsection{Ceilings}

Perform for each contaminant (contaminant specific variables are: contaminant factor)

Rad

Organic

Inorganic

Mercury

a) Cost Metal Ceiling Pre-Char.

$=($ Cost Avg $\times$ Area Metal Ceiling $\times \%$ area contaminated ceilings $\times$ contaminant factor $)+$ deployment cost

\subsubsection{Structural Steel}

Perform for each contaminant (contaminant specific variables are: contaminant factor)

Rad

Organic

Inorganic

Mercury

a) Cost Small Structural Steel Pre-Char.

$=($ Cost Avg $\times$ Area Small Structural Steel $\times \%$ area contaminated small SS $\times$ contaminant factor) + deployment cost

b) Cost Large Structural Steel Pre-Char.

$=($ Cost Avg $\times$ Area Lange Structural Steel $\times \%$ area contaminated large SS $\times$ contaminant factor) + deployment cost

\subsubsection{Instrument Tubing}

Perform for each contaminant (contaminant specific variables are: contaminant factor)

Rad

Organic

Inorganic

Mercury

a) Cost Tubing Pre-Char.

$=($ Cost Avg $\times$ Area Tubing $\times \%$ area contaminated $\mathbf{T} \times$ contaminant factor $)+$ deployment cost

\subsubsection{Small Piping}

Perform for each contaminant (contaminant specific variables are: contaminant factor)

Rad

Organic Inorganic

Mercury

a) Cost Inside Small Piping Pre-Char.

$=($ Cost Avg $\times$ Area Small Piping Inside $\times \%$ area contaminated ISP $\times$ contaminant factor $)+$ deployment cost

b) Cost Outside Small Piping Pre-Char.

$=($ Cost Avg $\times$ Area Small Piping Outside $\times \%$ area contaminated OSP $\times$ contaminant factor $)+$ deployment cost 


\subsubsection{Large Piping}

Perform for each contaminant (contaminant specific variables are: contaminant factor)

Rad

Organic

Inorganic

Mercury

a) Cost Inside Large Piping Pre-Char.

$=($ Cost Avg $\times$ Area Large Piping Inside $\times \%$ area contaminated ILP $\times$ contaminant factor $)+$ deployment cost

b) Cost Outside Large Piping Pre-Char.

$=($ Cost Avg $\times$ Area Large Piping Outside $\times \%$ area contaminated OLP $\times$ contaminant factor $)+$ deployment cost

\subsubsection{Ducting}

Perform for each contaminant (contaminant specific variables are: contaminant factor)

Rad

Organic

Inorganic

Mercury

a) Cost Inside Ducting Pre-Char.

$=($ Cost Avg $\times$ Area Ducting Inside $\times \%$ area contaminated ID $\times$ contaminant factor $)+$ deployment cost

b) Cost Outside Ducting Pre-Char.

$=($ Cost Avg $\times$ Area Ducting Outside $\times \%$ area contaminated OD $\times$ contaminant factor $)+$ deployment cost

\subsubsection{Glove Boxes}

Perform for each contaminant (contaminant specific variables are: contaminant factor)

Rad

Organic

Inorganic

Mercury

a) Cost Inside Glove Box Pre-Char.

$=($ Cost Avg $\times$ Area Glove Box Inside $\times \%$ area contaminated IGB $\times$ contaminant factor $)+$ deployment cost

a) Cost Outside Glove Box Pre-Char.

$=($ Cost Avg $\times$ Area Glove Box Outside $\times \%$ area contaminated OGB $\times$ contaminant factor $)+$ deployment cost

\subsection{Decontamination}

\subsubsection{Walls}

Perform for each contaminant (contaminant specific variables are: contaminant factor)

Rad 
Organic

Inorganic

Mercury

a) Weight Secondary Waste Metal Wall Decon

$=$ Area Metal Wall $\times \%$ area contaminated wall $\times$ contaminant factor $\times(s e c$. waste gen. rate $/$ production rate)

b) Cost Metal Wall Decon

$=($ Area Metal Wall $\times \%$ area contaminated wall $\times$ contaminant factor $\times$ Cost Avg $)+$ deployment cost

\subsubsection{Ceilings}

Perform for each contaminant (contaminant specific variables are: contaminant factor)

Rad

Organic

Inorganic

Mercury

a) Weight Secondary Waste Metal Ceiling decon

$=$ Area Metal Ceiling $\times \%$ area contaminated ceiling $\times$ contaminant factor $\times$ (sec. waste gen. rate / production rate)

b) Cost Metal Ceiling Decon

$=($ Area Metal Ceiling $\times \%$ area contaminated ceiling $\times$ contaminant factor $\times$ Cost Avg $)+$ deployment cost

\subsubsection{Structural Steel}

Perform for each contaminant (contaminant specific variables are: contaminant factor)

Rad

Organic

Inorganic

Mercury

a) Cost Small Structural Steel Decon

$=$ (Area Small Structural Steel $\times \%$ area contaminated small SS $\times$ contaminant factor $\times$ Cost Avg) + deployment cost

b) Cost Large Structural Steel Decon

$=$ (Area Large Structural Steel $\times \%$ area contaminated large SS $\times$ contaminant factor $\times$ Cost Avg) + deployment cost

c) Weight Secondary Waste Small Structural Steel Decon

$=$ Area Small Structural Steel $\times \%$ area contaminated small SS $\times$ contaminant factor $\times$ (sec. waste gen. rate / production rate)

d) Weight Secondary Waste Large Structural Steel Decon

$=$ Area Large Structural Steel $\times \%$ area contaminated large SS $\times$ contaminant factor $\times$ (sec. waste gen. rate / production rate)

\subsubsection{Glove Boxes}

Perform for each contaminant (contaminant specific variables are: contaminant factor) Rad 
Organic

Inorganic

Mercury

a) Weight Secondary Waste Inside Glove Box Decon

$=$ Area Glove Box Inside $\times \%$ area contaminated IGB $\times$ contaminant factor $\times$ (sec. waste gen . rate / production rate)

b) Weight Secondary Waste Outside Glove Box Decon

$=$ Area Glove Box Outside $\times \%$ area contaminated OGB $\times$ contaminant factor $\times$ (sec. waste gen. rate / production rate)

c) Cost Inside Glove Box Decon

$=($ Area Glove Box Inside $\times \%$ area contaminated IGB $\times$ contaminant factor $\times$ Cost Avg $)+$ deployment cost

d) Cost Outside Glove Box Decon

$=($ Area Glove Box Outside $\times \%$ area contaminated OGB $\times$ contaminant factor $\times$ Cost Avg $)+$ deployment cost

\subsection{Post-Characterization}

\subsubsection{Walls}

Perform for each contaminant (contaminant specific variables are: contaminant factor)

$\operatorname{Rad}$

Organic

Inorganic

Mercury

a) Cost Metal Wall Post-Char.

$=($ Cost Avg $\times$ Area Metal Wall $\times \%$ area contaminated walls $\times$ contaminant factor $)+$ deployment cost

\subsubsection{Ceilings}

Perform for each contaminant (contaminant specific variables are: contaminant factor)

Rad

Organic

Inorganic

Mercury

a) Cost Metal Ceiling Post-Char.

$=($ Cost Avg $\times$ Area Metal Ceiling $\times \%$ area contaminated ceilings $\times$ contaminant factor $)+$ deployment cost

\subsubsection{Structural Steel}

Perform for each contaminant (contaminant specific variables are: contaminant factor)

Rad

Organic

Inorganic

Mercury

a) Cost Small Structural Steel Post-Char. 
$=($ Cost Avg $\times$ Area Small Structural Steel $\times \%$ area contaminated small SS $\times$ contaminant factor) + deployment cost

b) Cost Large Structural Steel Post-Char.

$=($ Cost Avg $\times$ Area Large Structural Steel $\times \%$ area contaminated large $\mathbf{S S} \times$ contaminant factor) + deployment cost

\subsubsection{Glove Boxes}

Perform for each contaminant (contaminant specific variables are: contaminant factor)

Rad

Organic

Inorganic

Mercury

a) Cost Inside Glove Box Post-Char.

$=($ Cost Avg $\times$ Area Glove Box Inside $\times \%$ area contaminated IGB $\times$ contaminant factor $)+$ deployment cost

b) Cost Outside Glove Box Post-Char.

$=($ Cost Avg $\times$ Area Glove Box Outside $\times \%$ area contaminated OGB $\times$ contaminant factor $)+$ deployment cost

\subsection{Cutting/Sizing/Demolition}

\subsubsection{Walls}

a) Cost Metal Wall Cutting/Sizing/Demolition

$=($ Area Metal Wall $\times$ Cost Avg $\times 1.9)+$ deployment cost

\subsubsection{Ceilings}

a) Cost Metal Cutting/Sizing/Demolition

$=($ Area Metal Ceiling $\times$ Cost Avg $\times 1.7)+$ deployment cost

\subsubsection{Structural Steel}

a) Cost Cutting/Sizing Small Structural Steel

$=($ Number Cuts Small Structural Steel $\times$ Cost Avg $\times 0.725)+$ deployment cost

b) Cost Cutting/Sizing Large Structural Steel

$=($ Number Cuts Large Structural Steel $\times$ Cost Avg $\times 2.077)+$ deployment cost

\subsubsection{Instrument Tubing}

a) Cost Cutting/Sizing Tubing

$=($ Number Cuts Tubing $\times$ Cost Avg $\times 0.0345)+$ deployment cost

\subsubsection{Small Piping}


a) Cost Cutting/Sizing Small Piping

$=($ Number Cuts Small Piping $\times$ Cost Avg $\times$ 0.681) + deployment cost

\subsubsection{Large Piping}

a) Cost Cutting/Sizing Large Piping

$=$ (Number Cuts Large Piping $\times$ Cost Avg $\times 2.505)+$ deployment cost

\subsubsection{Ducting}

a) Cost Cutting/Sizing Ducting

$=($ Number Cuts Ducting $\times$ Cost Avg $\times$ 0.965) + deployment cost

\subsubsection{Glove Boxes}

a) Cost Cutting/Sizing/Demolition Glove Boxes

$=($ Number Glove Boxes $\times$ Cost Avg $\times$ 5.327 $)+$ deployment cost

\subsection{Disposal}

\subsubsection{Walls}

a) Weight Metal Wall Cutting/Sizing (based on assumed metal gauge or thickness) $=$ Area Metal Wall $\times$ metal density

b) Cost Metal Wall Cutting/Sizing Disposal

$=$ Weight Metal Wall Cutting/Sizing $\times$ CD disposal cost

c) Secondary waste disposed of on site. No allowance for contaminated HEPA filters.

Perform d for each contaminant

Rad

Organic

Inorganic

Mercury

d) Cost Metal Wall Decon Secondary Waste Disposal

$=$ Weight Secondary Waste Metal Wall Decon $\times$ sec. waste disposal cost

\subsubsection{Ceilings}

a) Weight Metal Ceiling Cutting/Sizing (based on assumed metal gauge or thickness) $=$ Area Metal Ceiling $\times$ metal density

b) Cost Metal Ceiling Cutting/Sizing Disposal

$=$ Weight Metal Ceiling Cutting/Sizing $\times$ CD disposal cost

c) Secondary waste disposed of on site. No allowance for contaminated HEPA filters.

Perform d for each contaminant 
$\operatorname{Rad}$

Organic

Inorganic

Mercury

d) Cost Metal Ceiling Decon Secondary Waste Disposal

$=$ Weight Secondary Waste Metal Ceiling Decon $\times$ sec. waste disposal cost

\subsubsection{Structural Steel}

a) Cost Small Structural Steel Cutting/Sizing Disposal

$=$ Weight Small Structural Steel $\times$ CD disposal cost

b) Cost Large Structural Steel Cutting/Sizing Disposal

$=$ Weight Large Structural Steel $\times$ CD disposal cost

c) Secondary waste disposed of on site. No allowance for contaminated HEPA filters.

Perform $d$ and $e$ for each contaminant

Rad

Organic

Inorganic

Mercury

d) Cost Small Structural Steel Decon Secondary Waste Disposal

$=$ Weight Secondary Waste Small Structural Steel Decon $\times$ sec. waste disposal cost

e) Cost Large Structural Steel Decon Secondary Waste Disposal

$=$ Weight Secondary Waste Large Structural Steel Decon $\times$ sec. waste disposal cost

\subsubsection{Instrument Tubing}

a) Cost Tubing Cutting/Sizing Disposal

$=$ Weight Tubing $\times$ CD disposal cost

\subsubsection{Small Piping}

a) Cost Small Piping Cutting/Sizing Disposal

$=$ Weight Small Piping $\times$ CD disposal cost

\subsubsection{Large Piping}

a) Cost Large Piping Cutting/Sizing Disposal

$=$ Weight Large Piping $\times$ CD disposal cost

\subsubsection{Ducting}

a) Cost Ducting Cutting/Sizing Disposal

$=$ Weight Ducting $\times$ CD disposal cost 


\subsubsection{Glove Boxes}

a) Cost Glove Box Cutting/Sizing Disposal $=$ Weight Glove Boxes $\times$ CD disposal cost

b) Secondary waste disposed of on site. No allowance for contaminated HEPA filters.

Perform $\mathrm{c}$ and $\mathrm{d}$ for each contaminant

Rad

Organic

Inorganic

Mercury

c) Cost Inside Glove Box Decon Secondary Waste Disposal

$=$ Weight Secondary Waste Inside Glove Box Decon $\times$ sec. waste disposal cost

d) Cost Outside Glove Box Decon Secondary Waste Disposal

$=$ Weight Secondary Waste Outside Glove Box Decon $\times$ sec. waste disposal cost

\subsection{Wood}

\subsection{Basic Information}

a) Area Wood Wall

$=$ Area Total Wall $\times \%$ area wood wall

b) Area Wood Ceiling

$=$ Area Total Ceiling $\times \%$ area wood ceiling

c) Area Wood Floor

$=$ Area Total Floor $\times \%$ area wood floor

\subsection{Pre-Characterization}

\subsubsection{Walls}

Perform for each contaminant (contaminant specific variables are: contaminant factor)

Rad

Organic

Inorganic

Mercury

a) Cost Wood Wall Pre-Char.

$=($ Cost Avg $\times$ Area Wood Wall $\times \%$ area contaminated walls $\times$ contaminant factor $)+$ deployment cost

\subsubsection{Ceilings}

Perform for each contaminant (contaminant specific variables are: contaminant factor)

Rad

Organic

Inorganic

Mercury 
a) Cost Wood Ceiling Pre-Char.

$=($ Cost Avg $\times$ Area Wood Ceiling $\times \%$ area contaminated ceilings $\times$ contaminant factor $)+$ deployment cost

\subsubsection{Floors}

Perform for each contaminant (contaminant specific variables are: contaminant factor)

Rad

Organic

Inorganic

Mercury

a) Cost Wood Floor Pre-Char.

$=($ Cost Avg $\times$ Area Wood Floor $\times \%$ area contaminated floors $\times$ contaminant factor $)+$ deployment cost

\subsection{Cutting/Sizing/Demolition}

\subsubsection{Walls}

a) Cost Wood Wall Cutting/Sizing/Demolition

$=($ Area Wood Wall $\times$ Cost Avg $)+$ deployment cost

\subsubsection{Ceilings}

a) Cost Wood Ceiling Cutting/Sizing/Demolition

$$
=(\text { Area Wood Ceiling } \times \text { Cost Avg })+\text { deployment cost }
$$

\subsubsection{Floors}

a) Cost Wood Floor Cutting/Sizing/Demolition

$=($ Area Wood Floor $\times$ Cost Avg $)+$ deployment cost

\subsection{Disposal}

\subsubsection{Walls}

a) Weight Wood Wall Cutting/Sizing CD Waste

$=$ Area Wood Wall $\times$ wood wall density $\times(1-\%$ area contaminated walls $)$

[ $2 \times 4$ const., $16^{n}$ center, $1 / 2^{n}$ dry wall]

b) Cost Wood Wall Cutting/Sizing CD Waste Disposal

$=$ Weight Wood Wall Cutting/Sizing CD Waste $\times$ CD disposal cost

Perform $c, d$ and e for each contaminant

Rad

Organic

Inorganic

Mercury

c) Weight Wood Wall Cutting/Sizing Primary Waste 
$=$ Area Wood Wall $\times$ wood wall density $\times \%$ area contaminated walls $\times$ contaminant factor

d) Cost Wood Wall Cutting/Sizing Primary Waste Transport

$=$ Weight Wood Wall Cutting/Sizing Primary Waste $\times$ transport cost (contaminant) $\times$ distance (contaminant)

e) Cost Wood Wall Cutting/Sizing Primary Waste Disposal

$=$ Weight Wood Wall Cutting/Sizing Primary Waste $\times$ primary waste disposal cost

(contaminant)

\subsubsection{Ceilings}

a) Weight Wood Ceiling Cutting/Sizing CD Waste

$=$ Area Wood Ceiling $\times$ wood ceiling density $\times(1-\%$ area contaminated ceilings $)$

[ $2 \times 4$ const., $16^{\prime \prime}$ center, $1 / 2^{n}$ dry ceiling]

b) Cost Wood Ceiling Cutting/Sizing CD Waste Disposal

$=$ Weight Wood Ceiling Cutting/Sizing CD Waste $\times$ CD disposal cost

Perform $c, d$ and $e$ for each contaminant

$\operatorname{Rad}$

Organic

Inorganic

Mercury

c) Weight Wood Ceiling Cutting/Sizing Primary Waste

$=$ Area Wood Ceiling $\times$ wood ceiling density $\times \%$ area contaminated ceilings $\times$ contaminant factor

d) Cost Wood Ceiling Cutting/Sizing Primary Waste Transport

$=$ Weight Wood Ceiling Cutting/Sizing Primary Waste $\times$ transport cost (contaminant) $\times$ distance

e) Cost Wood Ceiling Cutting/Sizing Primary Waste Disposal

$=$ Weight Wood Ceiling Cutting/Sizing Primary Waste $\times$ primary waste disposal cost

(contaminant)

\subsubsection{Floors}

a) Weight Wood Floor Cutting/Sizing CD Waste

$=$ Area Wood Floor $\times$ wood floor density $\times(1-\%$ area contaminated floors $)$

[ $2 \times 6$ const., $16^{\prime \prime}$ center, $3 / 4^{\prime \prime}$ flooring]

b) Cost Wood Floor Cutting/Sizing CD Waste Disposal

$=$ Weight Wood Floor Cutting/Sizing CD Waste $\times$ CD disposal cost

Perform $c, d$ and e for each contaminant

Rad

Organic

Inorganic

Mercury

c) Weight Wood Floor Cutting/Sizing Primary Waste 
$=$ Area Wood Floor $\times$ wood floor density $\times \%$ area contaminated floors $\times$ contaminant factor

d) Cost Wood Floor Cutting/Sizing Primary Waste Transport

$=$ Weight Wood Floor Cutting/Sizing Primary Waste $\times$ transport cost (contaminant) $\times$ distance (contaminant)

e) Cost Wood Floor Cutting/Sizing Primary Waste Disposal

$=$ Weight Wood Floor Cutting/Sizing Primary Waste $\times$ primary waste disposal cost (contaminant)

\subsection{LEAD BRICK}

\subsection{Basic Information}

a) Weight Lead Bricks

$=$ Number Lead Bricks $\times$ weight/brick

b) Area Lead Bricks

$=$ Number Lead Bricks $\times$ Lead Brick Area

\subsection{Pre-Characterization}

Perform for rad contaminant only

a) Cost Lead Brick Pre-Char.

$=($ Cost Avg $\times$ Area Lead Bricks $\times \%$ lead bricks contaminated $\times 1.25)+$ deployment cost

\subsection{Decontamination}

Perform for rad contaminant only

a) Cost Lead Brick Decon

$=($ Area Lead Bricks $\times \%$ lead bricks contaminated $\times$ Cost Avg $\times 1.25)+$ deployment cost

b) Weight Primary Waste Lead Brick Decon

$=$ Number Lead Bricks $\times \%$ lead bricks contaminated $\times$ Volume $\times$ lead density

where Volume $=(2 \times \mathrm{L} \times \mathrm{W} \times$ thickness removed per pass $)+(2 \times \mathrm{L} \times(\mathrm{H}-(2 \times$ thickness removed per pass $)) \times$ thickness removed per pass $)+(2 \times \mathrm{W}-(2 \times$ thickness removed per pass $)) \times(\mathrm{H}-(2$ $x$ thickness removed per pass)) $\times$ thickness removed per pass)

c) Weight Secondary Waste Lead Brick Decon

$=$ Area Lead Bricks $\times \%$ lead bricks contaminated $\times$ (sec. waste gen. rate $/$ production rate $)$

\subsection{Post-Characterization}

Perform for rad contaminant only

a) Cost Lead Brick Post-Char. $=($ Cost Avg $\times$ Area Lead Bricks $\times \%$ lead bricks contaminated $\times 1.25)+$ deployment cost

\subsection{Cutting/Sizing/Demolition}

a) Cost Lead Brick Removal

$=($ Number Lead Bricks $\times$ Cost Avg) + deployment cost 


\subsection{Disposal}

Perform for rad contaminant only

a) Secondary waste disposed of on site. No allowance for contaminated HEPA filters.

b) Cost Lead Brick Decon Primary Waste Transport

$=$ Weight Primary Waste Lead Brick Decon $\times$ transport cost $(\mathrm{rad}) \times$ distance $(\mathrm{rad})$

c) Cost Lead Brick Decon Primary Waste Disposal

$=$ Weight Primary Waste Lead Brick Decon $\times$ primary waste disposal cost (rad)

d) Cost Lead Brick Decon Secondary Waste Disposal

$=$ Weight Secondary Waste Lead Brick Decon $\times$ sec. waste disposal cost

e) Cost Active Lead Brick Transport

$=$ weight/brick $\times$ Number Lead Bricks $\times \%$ lead bricks contaminated $\times \%$ active bricks $\times$ transport cost (rad) $\times$ distance (rad)

f) Cost Active Lead Brick Disposal

$=$ weight/brick $\times$ Number Lead Bricks $\times \%$ lead bricks contaminated $\times \%$ active bricks $\times$ primary waste disposal cost (rad)

g) Cost Decon Lead Brick Disposal

$=$ (Weight Lead Bricks - Weight Primary Waste Lead Brick Decon - (Number Lead Bricks $\times \%$ lead bricks contaminated $\times \%$ active bricks $\times$ weight/brick)) $\times$ disposal cost lead brick

\subsection{ASBESTOS}

\subsection{Basic Information}

a) Weight Small Pipe Lagging

$=$ Length Small Pipe Lagging $\times$ weight/length lagging SP

b) Weight Large Pipe Lagging

$=$ Length Large Pipe Lagging $\times$ weight/length lagging LP

c) Weight Insulation

$=$ Area insulation $\times$ weight/area insulation

\subsection{Pre-Characterization}

a) Cost Small Pipe Lagging Pre-Char.

$=($ Cost Avg $\times$ Length Small Pipe Lagging $)+$ deployment cost

b) Cost Large Pipe Lagging Pre-Char.

$=($ Cost Avg $\times$ Length Large Pipe Lagging $)+$ deployment cost

c) Cost Insulation Pre-Char.

$=($ Cost Avg $\times$ Area Insulation $)+$ deployment cost 


\subsection{Decontamination}

a) Decontamination is equivalent to removal.

b) Cost Small Pipe Lagging Decon

$=($ Length Small Pipe Lagging $\times$ Cost Avg $\times 1)+$ deployment cost

c) Cost Large Pipe Lagging Decon

$=($ Length Large Pipe Lagging $\times$ Cost Avg $\times 2)+$ deployment cost

d) Cost Insulation Decon

$=($ Area Insulation $\times$ Cost Avg $)+$ deployment cost

\subsection{Post-Characterization}

a) Cost Small Pipe Lagging Post-Char.

$=($ Cost Avg $\times$ Length Small Pipe Lagging $)+$ deployment cost

b) Cost Large Pipe Lagging Post-Char.

$=($ Cost Avg $\times$ Length Large Pipe Lagging $)+$ deployment cost

c) Cost Insulation Post-Char.

$=($ Cost Avg $\times$ Area Insulation $)+$ deployment cost

\subsection{Cutting/Sizing/Demolition}

a) Asbestos lagging and insulation should have been removed in decontamination process.

\subsection{Disposal}

a) Cost Small Pipe Lagging Primary Waste Transport

$=$ Weight Small Pipe Lagging $\times$ transport cost (inorganic) $\times$ distance (inorganic)

b) Cost Large Pipe Lagging Primary Waste Transport

$=$ Weight Large Pipe Lagging $\times$ transport cost (inorganic) $\times$ distance (inorganic)

c) Cost Insulation Primary Waste Transport

$=$ Weight Insulation $\times$ transport cost (inorganic) $\times$ distance (inorganic)

d) Cost Small Pipe Lagging Primary Waste Disposal

$=$ Weight Small Pipe Lagging $\times$ primary waste disposal cost (inorganic)

e) Cost Large Pipe Lagging Primary Waste Disposal

$=$ Weight Large Pipe Lagging $\times$ primary waste disposal cost (inorganic)

f) Cost Insulation Primary Waste Disposal

$=$ Weight Insulation $\times$ primary waste disposal cost (inorganic)

\subsection{TRANSITE}




\subsection{Basic Information}

a) Weight Transite

$=$ Area Transite $\times \underline{\text { weightarea } T}$

\subsection{Pre-Characterization}

a) Cost Transite Pre-Char.

$=($ Cost Avg $\times$ Area Transite $)+$ deployment cost

\subsection{Decontamination}

a) Cost Transite Decon

$=($ Area Transite $\times$ Cost Avg $)+$ deployment cost

\subsection{Post-Characterization}

a) Cost Transite Post-Char.

$=($ Cost Avg $\times$ Area Transite $)+$ deployment cost

\subsection{Cutting/Sizing/Demolition}

a) Transite should have been removed in decontamination process.

\subsection{Disposal}

a) Cost Transite Primary Waste Transport

$=$ Weight Transite $\times$ transport cost (inorganic) $\times$ distance (inorganic)

b) Cost Transite Primary Waste Disposal

$=$ Weight Transite $\times$ primary waste disposal cost (inorganic)

\subsection{Surveillance \& Maintenance}

a) for years < PBS start

S\&M cost $=$ Size $\times \underline{\text { cost } / y r-a r e a ~ S M} \times($ PBS Start - year $)$

b) for years > PBS End

$S \& M$ cost $=0$

c) for years $>$ PBS Start and < PBS End

S\&M cost $=$ Sum [Size $\times$ cost/yr-area SM $\times(($ PBS End - PBS Start +1$)-$ $($ year - PBS Start + 1))/(PBS End - PBS Start + 1)]

for year = PBS Start to PBS End 


\section{APPENDIX B}

\section{D\&D TECHNOLOGIES ASSESSMENT: TECHNOLOGY LIST}




\title{
D\&D TECHNOLOGIES ASSESSMENT: TECHNOLOGY LIST (Version 2.1)
}

\author{
Draft Final Technical Report
}

Prepared for:

Dr. Paul Hart

Decontamination \& Decommissioning Area Leader

Federal Energy Technology Center

U.S. Department of Energy

3610 Collins Ferry Road

PO Box 880, Mail Stop E06

Morgantown, WV 26507-0880

Prepared by:

Thomas A. Erickson

Mark A. Musich

David J. Murray

Steven J. Cisney

Erin M. O'Leary

Energy \& Environmental Research Center

PO Box 9018

Grand Forks, ND 58202-9018

Carey Butler

Robert Vagnetti

Waste Policy Institute

1224 Pineview Drive

Morgantown, WV 26505

September 1998 


\section{TABLE OF CONTENTS}

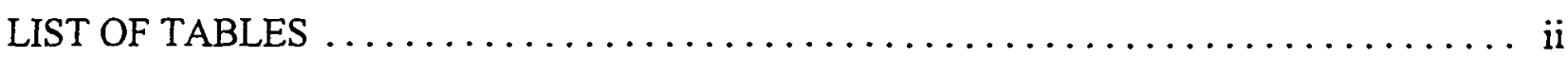

$1.0 \quad$ INTRODUCTION $\ldots \ldots \ldots \ldots \ldots \ldots \ldots \ldots \ldots \ldots \ldots \ldots \ldots \ldots \ldots \ldots \ldots \ldots \ldots$

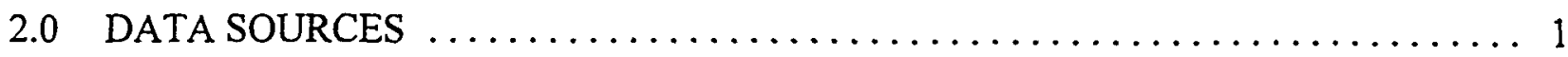

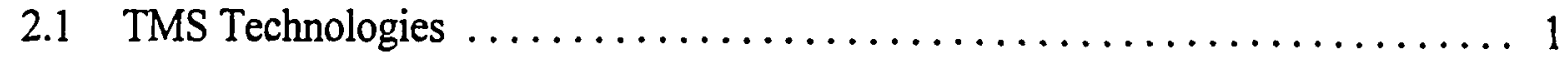

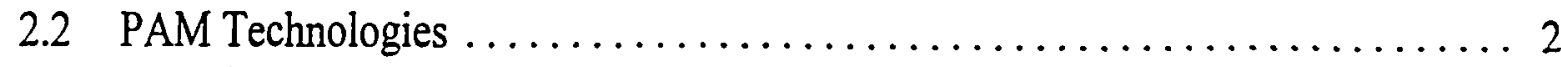

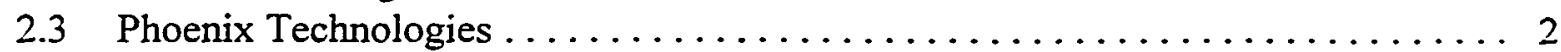

2.4 Nonselected LSDP Technologies $\ldots \ldots \ldots \ldots \ldots \ldots \ldots \ldots \ldots \ldots \ldots \ldots \ldots \ldots \ldots \ldots \ldots$

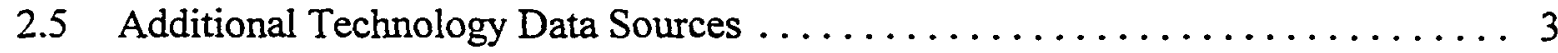

2.5 .1 TechKnow Database ........................... 3

2.5.2 Remediation Technologies Screening Matrix and Reference Guide

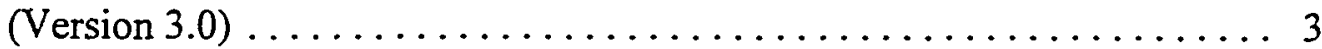

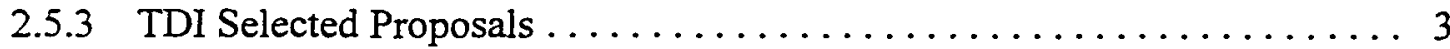

2.5.4 GWRTAC Technical Documents ....................... 3

2.5.5 EPA ORD/ATTIC ................................ 3

2.5.6 Envirotrade Technology Summaries .................... 4

2.5.7 Remediation Technologies Screening Matrix and Reference Guide . ..... 4

2.5.8 ENVIRO-ACCESS Environmental Technologies Fact Sheets $\ldots \ldots \ldots 4$

2.6 Innovative Technology Summary Reports $\ldots \ldots \ldots \ldots \ldots \ldots \ldots \ldots$

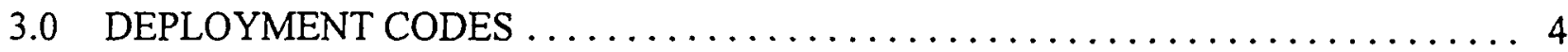

3.1 Development of Deployment Codes $\ldots \ldots \ldots \ldots \ldots \ldots \ldots \ldots \ldots \ldots \ldots$

3.2 Listing of Deployment Codes $\ldots \ldots \ldots \ldots \ldots \ldots \ldots \ldots \ldots \ldots \ldots$

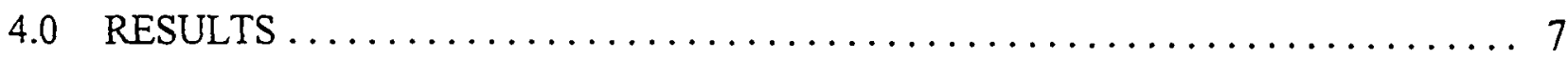

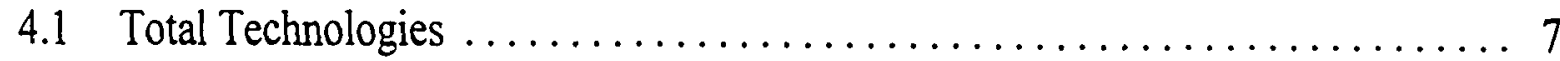

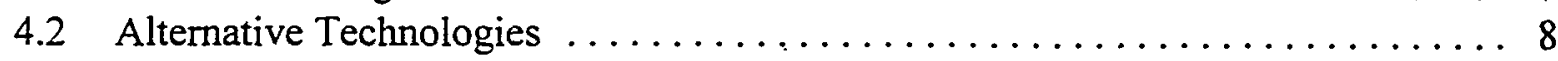

4.3 Baseline Technologies $\ldots \ldots \ldots \ldots \ldots \ldots \ldots \ldots \ldots \ldots \ldots \ldots \ldots \ldots$

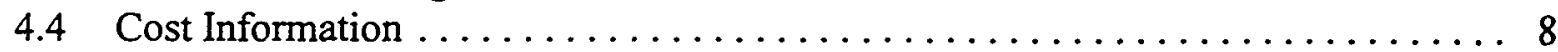

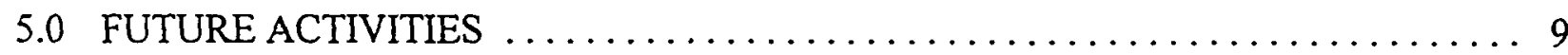

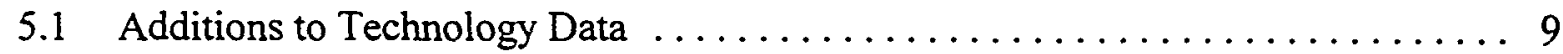

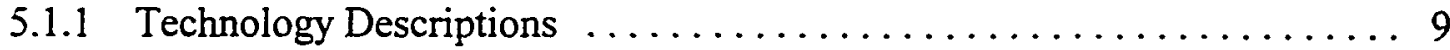

5.1 .2 Operating Rates and Capabilities $\ldots \ldots \ldots \ldots \ldots \ldots \ldots \ldots \ldots \ldots$

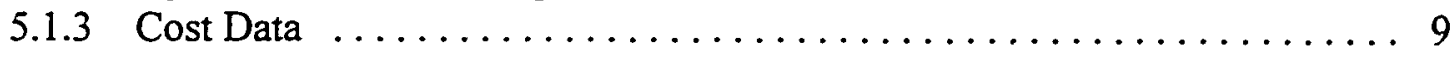

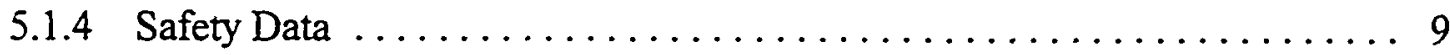

5.1.5 Operability and Maintainability Data $\ldots \ldots \ldots \ldots \ldots \ldots \ldots \ldots, \ldots$

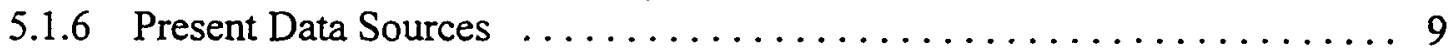

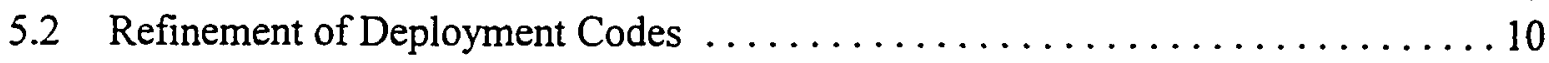



Appendix B

A3. ECC CODES Appendix C A4. ASSUMPTIONS Appendix D A5. COST AND SECONDARY WASTE INFORMATION Appendix E

\section{LIST OF TABLES}

1 Deployment Code Listing 5 


\section{D\&D TECHNOLOGIES ASSESSMENT: TECHNOLOGY LIST (Version 2.1)}

\subsection{INTRODUCTION}

This report describes and summarizes the results obtained by the Energy \& Environmental Research Center (EERC) after collecting and examining the available data concerning technologies applicable to decontamination and decommissioning (D\&D). A total of 533 technologies have been identified for use in D\&D activities. Among these, 126 are termed alternative technologies, which have received U.S. Department of Energy (DOE) funding for research, development, or demonstration, and the remaining 407 are termed baseline. For each technology, a series of deployment codes were developed which identify the capabilities of the technology. Data for determination of fixed and variable costs were as well as associated secondary waste generation rates found in 44 Innovative Technology Summary Reports (ITSRs). Of these, only 22 covered technologies suitable for use in the current version of the model. Section 2 of this report reviews the sources of data used for information concerning the technologies. Section 3 describes the deployment codes used both for technologies and remediation needs. Section 4 presents a summary of the results obtained to date, and Section 5 discusses future activities.

To make the Technology List upgradable and easily accessible for searching and inclusion in other data management systems, it has been placed into an Excel spreadsheet format. A copy of the spreadsheet is attached in the disk holder at the back of this document, and hard copies of each of the sheets are in the appendices.

\subsection{DATA SOURCES}

The following sources were used to collect information about the technologies in Version 2.1 of the Technology List created by the EERC.

\subsection{TMS Technologies}

The Technology Management System (TMS) was created for EM-50 to aid in the tracking of alternative technologies and to make the information more accessible to the sites for identifying cleanup technologies. The TMS database is available on the World Wide Web.

The TMS database provides a structured mechanism for assessing the status of a particular technology development effort, but lacks information about the performance of that technology. Where fully populated, the TMS system provides good descriptions of the technologies, but, commonly, backup information sources were used to gather the specifics.

For this activity, TMS datasheets were initially retrieved from the Office of Science and Technology (OST) TMS web site on February 2, 1998, and updated datasheets were retrieved on 


\section{DRAFT}

February 12, February 26, March 2, and March 3, 1998. Only those technologies listed as D\&D or related technologies are included in Version 2.1 of the D\&D Technology List.

\subsection{PAM Technologies}

The EM-40 Preferred Alternatives Matrices (PAM) Rev. 2 (June 30, 1997) was retrieved from the World Wide Web. PAM is an effort by DOE's Office of Environmental Restoration (EM-40) to determine the commercial state of practice and provide a tool for field elements when selecting a technology remedy. The PAM study also performed an analysis similar to the deployment codes in this study. In most cases, the information on the technologies is minimal in this report; however, their preferred decontamination technology (PDT) analysis was used to gather additional information about the technologies.

\subsection{Phoenix Technologies}

The DOE Federal Energy Technology Center (FETC) Phoenix D\&D Technology Module Version 1.0 database, which was furnished on CD-ROM, is a searchable compendium of nuclear $D \& D$-related data. The module currently contains six categories of D\&D technologies, namely cutting tools, decontamination processes, dismantling techniques, safety equipment, robotics, and waste-handling methods. Module 1 is severely lacking in supporting information for the technologies, and much of the analysis for this study relied on sound engineering judgment without backup information about the technologies.

The Phoenix technologies are the largest group, since different sizes or models of the same technology are listed as separate technologies. This decision was based on the fact that in the future each size or model of a technology may have its distinct deployment code.

Technology Module Version 2.0 was briefly reviewed. Although the number of technologies had grown considerably, the types of technologies did not fit the current version of the D\&D model.

\subsection{Nonselected LSDP Technologies}

Copies and summary tables of the technology evaluation forms were reviewed for each of the large-scale demonstration projects (LSDPs). In addition, Links to DOE Site Decommissioning Projects (particularly LSDPs) were followed and examined for any further information they may contain. Technologies were included in the Technology List based on these sheets; however, because supporting information was lacking, the technologies were only included for the exact purpose they were reviewed within the LSDPs. No judgment was made as to additional uses for these technologies beyond the strict confines of the original LSDP intentions. 


\section{DRAFT}

\subsection{Additional Technology Data Sources}

In addition, the following information sources were examined in relation to the information required by the Needs Analysis. While numerous technologies were represented, these sources did not appear to contain any information that was not already available. In addition, the information in many of the sources was 1 to $1 \frac{1 / 2}{2}$ years old. None of these data have been used for Version 2.1 of the Technology List.

\subsubsection{TechKnow Database}

TechKnow is an on-line database which allows Internet users to share and receive technical solutions to environmental problems. Technologies are categorized by contaminant, media, and name. Profiles of technologies include summaries, development and intellectual property status, and cost. Licensing availability and contact information are also included.

\subsubsection{Remediation Technologies Screening Matrix and Reference Guide (Version 3.0)}

To assist the remedial project manager (RPM) in the remediation evaluation process and to enhance technology transfer among federal agencies, the Federal Remediation Technologies Roundtable developed this web site to combine the unique features of several agency publications into a single information source.

\subsubsection{TDI Selected Proposals}

The Technology Deployment Initiative (TDI) mission is to deploy technologies and processes that reduce the DOE Environmental Management (EM) costs, accelerate site cleanup, and support Ten-Year Plan goals and schedules. The selected proposals contain technology descriptions, but no data.

\subsubsection{GWRTAC Technical Documents}

Available on-line, GWRTAC includes technology status, evaluation, overview, and information reports. All data are from 1996 to present. These are primarily groundwater remediation technologies.

\subsubsection{EPA ORD/ATTIC}

The U.S. Environmental Protection Agency (EPA) Office of Research \& Development Alternative Treatment Technology Information Center (ORD/ATTIC) is a comprehensive computer database system providing up-to-date information on innovative treatment technologies. ATTIC Version 2.1 provides access to several independent databases, as well as a mechanism for retrieving full-text documents of key literature. This database is primarily concerned with hazardous waste cleanup. 


\section{DRAFT}

\subsubsection{Envirotrade Technology Summaries}

Maintained by the National Technology Transfer Center, this is a database that maintains descriptions and graphics on worldwide waste sites and technologies. The database contains information from federal and university laboratories.

\subsubsection{Remediation Technologies Screening Matrix and Reference Guide}

Developed by the Federal Remediation Technologies Roundtable and containing information from seven government agencies, this guide is intended to allow the reader to gather essential descriptive information on the respective treatment technologies. It incorporates cost and performance data to the maximum extent available. These technologies are applicable for common pollutants, but the section on radionuclides contained no data.

\subsubsection{ENVIRO-ACCESS Environmental Technologies Fact Sheets}

These fact sheets display various commercial environmental technologies available through Quebec Enterprises. These technologies were developed in Canada and are primarily concerned with the remediation of commercial sites, with no particular application to D\&D.

\subsection{Innovative Technology Summary Reports}

Reports on LSDPs called ITSRs were retrieved from two FTP sites and through the DOE FETC home page. In the LSDPs, innovative. (alternative) and baseline technologies were tested in performance of actual D\&D activities. The ITSRs were created as summaries of these comparisons. Concise technology descriptions and discussions of both objective and subjective observations were given. All of the reports covered observed costs, performance, secondary waste generation, ALARA and safety, and ease of use and implementation. For current purposes, the cost information and secondary waste generation data presented were of greatest interest.

\subsection{DEPLOYMENT CODES}

\subsection{Development of Deployment Codes}

Deployment codes (also called PDT or environmental condition criteria [ECC] codes) are a systematic assignment of code numbers that correspond to a particular application of a technology within the $D \& D$ area. The assignment of a deployment code serves to differentiate one type of application from another. The codes are assigned beginning with the most general and becoming more and more specific as further levels are assigned. It should be noted that a deployment code can be used both to describe a cleanup need that exists and a technology that is potentially available for use in that situation. For this assessment, the deployment codes were developed for five levels of differentiation. As a result, the deployment code for a particular situation consists of a series of five 2-digit numbers.

\subsection{Listing of Deployment Codes}

Table 1 shows the deployment codes by level, category, and code number. 


\section{DRAFT}

\section{TABLE 1}

Deployment Code Listing

\begin{tabular}{llc}
\hline Level & \multicolumn{1}{c}{ Categories } & Code \\
\hline & Blank (Insufficient information/no applicable subcategories) & 99 \\
$00 \quad$ Decommissioning categories & \\
Other & 00 \\
Facility construction & 01 \\
& Decommissioning residue & 02 \\
& Material types & \\
Other & 00 \\
Concrete/masonry/brick & 01 \\
Metal & 02 \\
Wood & 03 \\
Asbestos/transite & 04 \\
Solids/debris & 05 \\
Sludge & 06 \\
Liquid & 07
\end{tabular}

02 Process types

Characterization 01

Decontamination . 02

Cutting \& sizing $\quad$. $\quad 03$

Demolition $\quad 04$

Material disposition 05

Worker safety \& health $\quad 06$

Remote tooling/automation $\quad 07$

$\begin{array}{ll}\text { Treatment } & 08\end{array}$

03 Process subtypes

\section{Characterization}

Large/complex areas 01

Internal characterization (pipes, ducts, process equipment) 02

Inaccessible areas (confined space, behind walls, containers) 03

Structural integrity inspection $\quad 04$

Buried objects 05

Equipment components, walls, ceilings, irregular floors 06

Concrete decontamination subtypes

Floors

Walls \& ceilings

Metal decontamination subtypes

Lead bricks

Equipment/glove boxes/dismantled piping 10

Sheet metal/structural Steel/steel liners 11

$\begin{array}{ll}\text { System piping/tank internals } & 12\end{array}$

Concrete cutting $\&$ sizing subtypes 
TABLE 1 (continued)

\begin{tabular}{|c|c|c|}
\hline \multirow[t]{5}{*}{ Level } & Categories & Code \\
\hline & Heavily reinforced & 13 \\
\hline & Unreinforced & 14 \\
\hline & Walls \& floors & 15 \\
\hline & \multicolumn{2}{|l|}{ Metal cutting \& sizing subtypes } \\
\hline & Instrument tubing & 16 \\
\hline & Large-diameter piping & 17 \\
\hline & Small-diameter piping & 18 \\
\hline & Flat stock \& pressure vessels & 19 \\
\hline & Structural steel & 20 \\
\hline & Lead bricks & 21 \\
\hline \multicolumn{3}{|c|}{ Demolition subtypes } \\
\hline & Reinforced & 22 \\
\hline & Lightly reinforced & 23 \\
\hline & Nonreinforced & 24 \\
\hline & Stack & 25 \\
\hline & Structure & 26 \\
\hline & Sheathing intact & 27 \\
\hline & Sheathing removed & 28 \\
\hline \multicolumn{3}{|c|}{ Disposition subtypes } \\
\hline & Handling & 29 \\
\hline & Sorting & 30 \\
\hline & Packaging & 31 \\
\hline & Recycle & 32 \\
\hline & Waste minimization/disposal & 33 \\
\hline \multicolumn{3}{|c|}{ Worker safety \& health subtypes } \\
\hline & Hazards monitoring/control (including air monitoring) & 34 \\
\hline & Personnel-monitoring equipment & 35 \\
\hline & Personnel protective equipment & 36 \\
\hline \multicolumn{3}{|c|}{ Treatment subtypes } \\
\hline & Organic contaminants & 37 \\
\hline & Inorganic contaminants & 38 \\
\hline & Radioactive contaminants & 39 \\
\hline & Mixed low-level waste ( $L L W$ )/organic & 40 \\
\hline & Mixed LLW/inorganic & 41 \\
\hline & Asbestos/transite & 42 \\
\hline & Lead & 43 \\
\hline 04 & \multirow{2}{*}{\multicolumn{2}{|c|}{$\begin{array}{l}\text { Condition categories } \\
\text { Concrete decontamination categories }\end{array}$}} \\
\hline & Concrete decontamination categories & \\
\hline & Large areas & 01 \\
\hline & Small areas & 02 \\
\hline
\end{tabular}




\section{DRAFT}

TABLE 1 (continued)

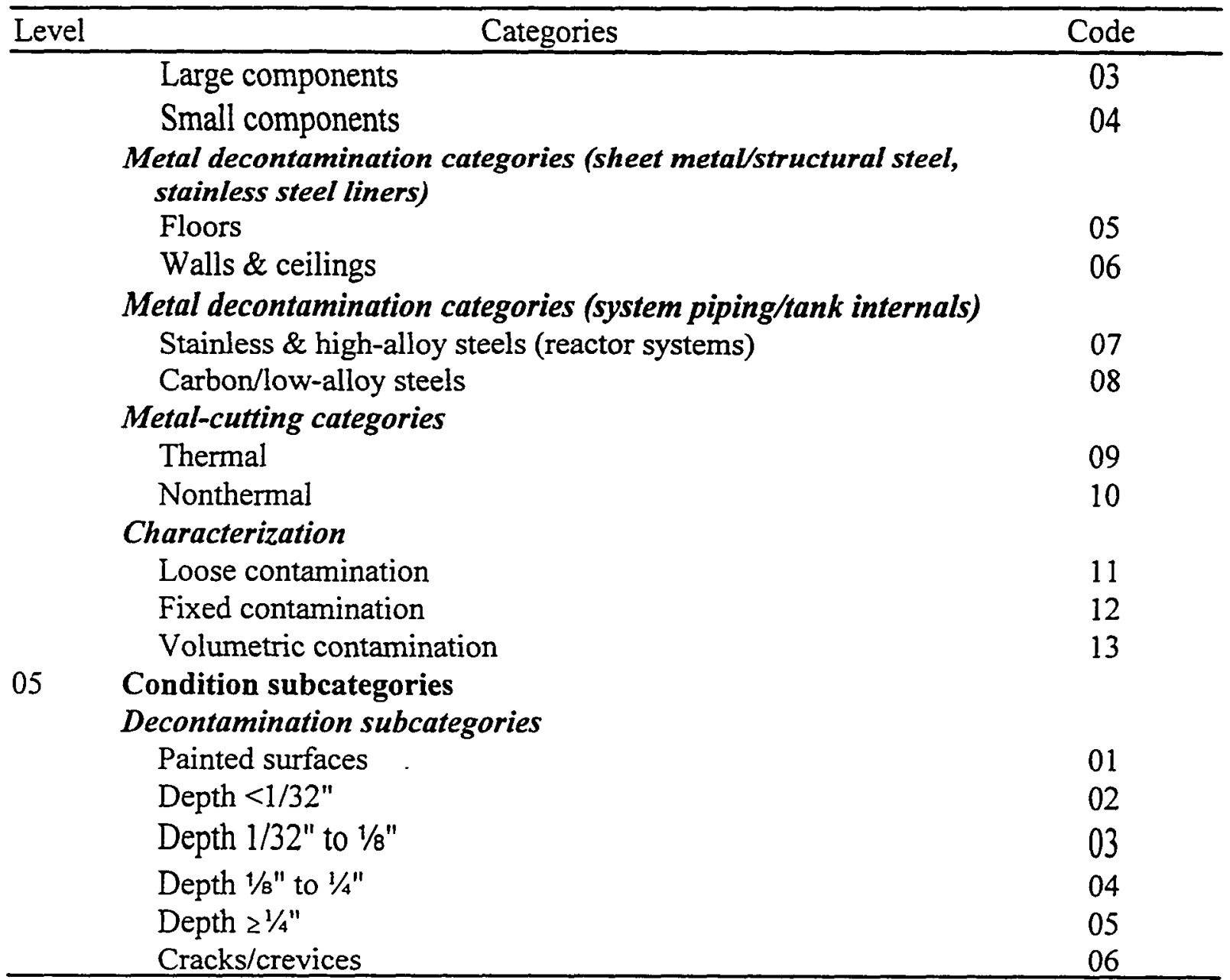

\subsection{RESULTS}

\subsection{Total Technologies}

A total of 533 technologies are available for consideration in future D\&D planning. Of these, 92 are TMS technologies, 109 are PAM technologies, 244 are Phoenix database technologies, 60 are technologies that were considered but not selected for the LSDPs, 13 are technologies from ODS Table 0.9.1, and 15 are baseline technologies from the ITSRs.

The large number of technologies and the relatively incomplete associated information made it difficult to eliminate all duplicates in the technology spreadsheet. Duplicates primarily exist for the baseline technologies. This difficulty is compounded by inconsistencies in naming technologies in the various data sources, e.g., TMS compared to LSDP. 


\subsection{Alternative Technologies}

The 92 TMS technologies were classified as alternative technologies. In addition, 21 technologies in the Phoenix database that were not considered to be commercially available and the 13 technologies from ODS Table 0.9.1 were also included in this category.

\subsection{Baseline Technologies}

All 109 PAM technologies were considered to be commercially available and were listed as baseline technologies. In addition, 223 technologies from the Phoenix database were also identified as commercially available and were likewise considered to be baseline technologies. Also, all of the technologies reviewed but not selected for the LSDPs were included.

\subsection{Cost Information}

The cost information presented in the ITSRs for the alternative and baseline technologies tended to be thorough but was not always complete or accurate. It was to be presented in a format defined by a work breakdown structure which was not rigorously followed in all cases. A common fault was to apparently neglect the cost of disposal of materials. Further, if a given baseline technology was used in several ISTRs, the costs were not always consistently presented. Also, within the same ISTR, a piece of equipment having the same ownership status can be presented as needing transport to the site in one instance and not in another.

Lacking all of the information available to the authors of the ISTRs, the apparent errors were dealt with using reasonable engineering judgment. An effort was made to include costs consistently. No significant attempt was made to create or include information that the ITSR authors omitted. Adjustments were made, for example, when loading, unloading, and on-site transport of the demonstrated technology was obviously warranted but not included by the ITSR authors.

Cost information presented in the reports was condensed to a format consistent with the model developed at the EERC. The cost information used by the model was essentially broken down to fixed and variable costs and is presented in Appendix E. Fixed costs were considered to be those associated with equipment (technology) transport, decontamination, setup and dismantlement, etc., at the building/site. The variable costs were those which depended on the duration and quantity of work done at the building/site. Costs such as the purchase of major equipment or, in some cases, transport to the area where there are presumed to be more than one building/site to be dealt with have not yet been made consistent with the model or the model altered to use those data.

The model currently deals with secondary waste generation rates on a kilogram per hour basis. When given, the secondary waste generation rates in the ITSRs were reported on a volume basis. Where those wastes comprised PPE and other such materials, a density of 64 kilograms per cubic meter was assumed. Secondary waste generation used in the model is also presented in Appendix A5. In some cases, the secondary waste information was reported as a cost of disposal. That information was included directly in the variable cost entered for the technology. 


\subsection{FUTURE ACTIVITIES}

Two areas where further work will prove fruitful in the future are additions to the data that are available for each technology and refinement of the deployment codes.

\subsection{Additions to Technology Data}

The following are areas where further definition and supplemental data are needed for many of the technologies in order to make sound decisions concerning their applicability.

\subsubsection{Technology Descriptions}

This information is required principally for assessing the application of the technology within D\&D and to facilitate development of the deployment code.

\subsubsection{Operating Rates and Capabilities}

Operating rate and capabilities data are required for calculation of operating cost and calculation of waste (primary and secondary) volumes.

\subsubsection{Cost Data}

Cost data (e.g., operating, maintenance, capital waste disposal, waste transport, etc.) are required for calculation of Process economics.

\subsubsection{Safety Data}

This information is necessary to allow comparison of technology choices based on a qualitative rather than just quantitative (cost) basis.

\subsubsection{Operability and Maintainability Data}

This information is necessary to allow comparison of technology choices based on a qualitative rather than just quantitative (cost) basis.

\subsubsection{Present Data Sources}

TMS technology information has principally been found on the OST Information Inventory. Several D\&D TMS technology overviews are deficient in either a technical or a general description. Further, this database was not developed to provide safety, operability, and maintainability data. The Information Inventory needs to be updated or the principal investigators or vendors for the TMS technologies should be queried directly. 


\section{DRAFT}

The PAM database provided limited information on operating rates and capabilities and cost data. No information is available for safety, operability, and maintainability data. PAM does provide reference sources for each technology.

The Phoenix Decision Support Tool Module 1.0 was totally deficient in technology descriptions. Sporadic information was provided for operating rates and cost data. The developer of the Phoenix database may have to be queried for this information or the vendors may have to be queried directly.

The nonselected LSDP technology information was found on the LSDP evaluation forms. These forms provided abbreviated technology descriptions only. Data for operating rates and capabilities, cost, safety, operability, and maintainability were not available and will have to be obtained directly from vendors.

\subsection{Refinement of Deployment Codes}

Further work is needed in this area, particularly in obtaining an exact match between the hierarchy of technology codes and the hierarchy of need codes. Presently, it is uncertain whether the hierarchy used for development of need deployment codes is identical to the hierarchy that was used for the development of technology deployment codes. Without identical hierarchy, it is possible that a need could appear not to have a potential solution when relying on deployment codes for need and technology matches. Similarly, without any needs to match a technology, it would appear that a technology was developed for an unspecified application.

The current information concerning available $D \& D$ technologies is presented in spreadsheet form. The spreadsheet has six pages, which contain the following information:

A.1 Read Me First: This contains introductory material and further description of other pages.

A.2 Selected Technologies: This is a list of selected technologies and their characteristics.

A.3 ECC Codes: This is another list of selected technologies with their accompanying deployment (PDT) codes.

A.4 Assumptions: This lists the assumptions for each group of technologies (TMS, PAM, etc.) and a description of the deployment codes. 


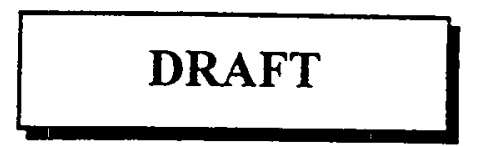

APPENDIX A

\section{A1. READ ME FIRST}




\section{Version 2.1}

The following series of spreadsheels outline the current list of technologies considered to be in the D\&D focus area portfolio. This list was developed for the D\&D Needs Analysis. The following describes the various sheets within this file.

\section{Selected Technologies}

Contains the technologies included in version 2.1 of this list as finalized on 3/23/98. The data sources included and the assumptions made in generating this list can be found later in the spreadsheet. This sheet contains the technology name and identifiers as well as the information related to the commercial availability of the technology and the vendor contacts.

\section{Deployment Codes}

For every lechnology at least one set of Preferred Deployment Technology (PDT) codes exists. These codes describe where the technology can be applied within the D\&D Focus Area. For many technologies, multiple PDT's exist.

\section{Assumptions}

Contains the description for the system used to assign PDT's as well as a list of assumptions for each of the data sources examined to date. Knowledge of these assumptions are essential for proper interpretation of the information within this file.

LSDP's not in TMS

Contains LSDP technologies that could not be found within the TMS system. These technologies are to be researched further.

Non-Selected Technologies

Contains technologies that were originally added to the list but have since been removed. This is strictly for tracking purposes. These technologies

were removed due to discontinued funding or very poor performance/applicability to D\&D. This list contains technologies that require further

information gathering including whether they were evaluated during LSOP's but rejected or potentially duplicated technologies with subtle title changes.

\section{Data Sources}

Contains a list of all of the data sources used in the development of this list to date. Contains data sources that were used as well as those that were not used for various reasons.

\section{Replicated Deployment Codes}

Deployment codes were assigned to D\&D technologies. Particularly in the case of PAM treatment technologies, codes chosen to characterize technologies exceeded the actual limits of the codes. When extraneous codes were converted to ' 99 ', many effectively became duplicates. These duplicates were moved to this sheet. 


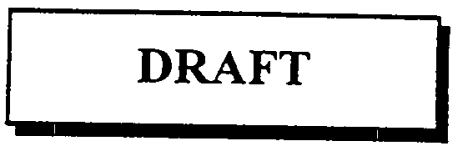

APPENDIX B

\section{A2. SELECTED TECHNOLOGIES}


D\&DLs12.1 1 x3

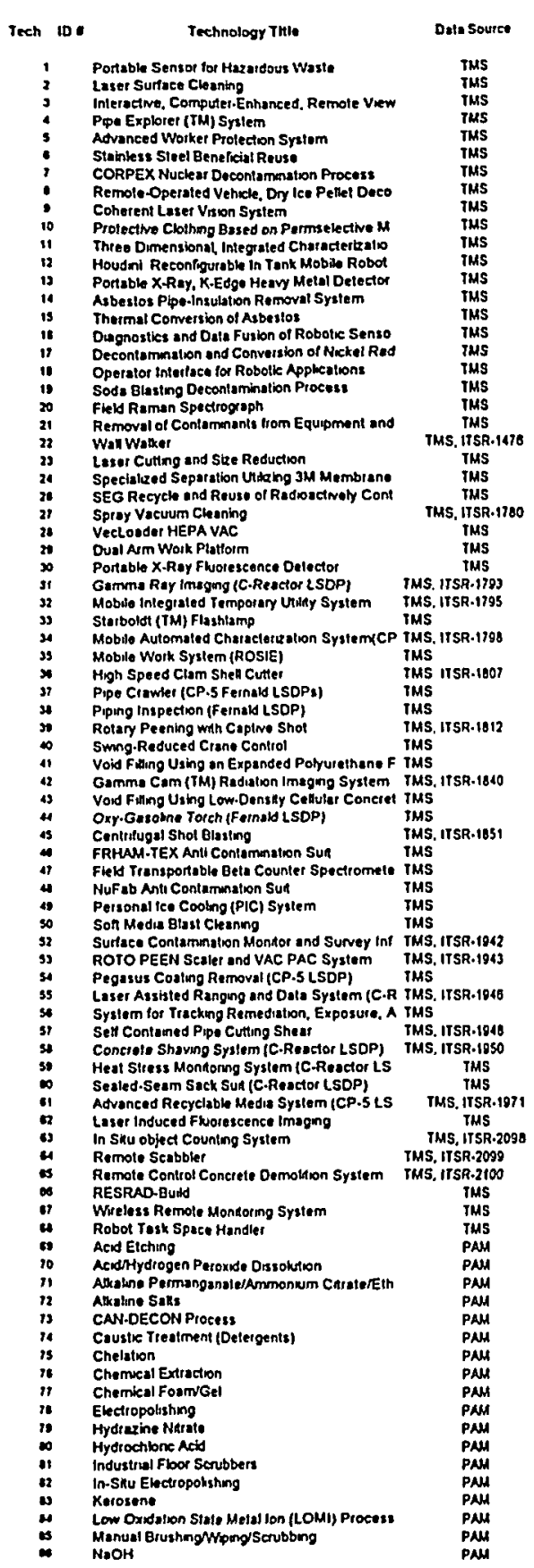

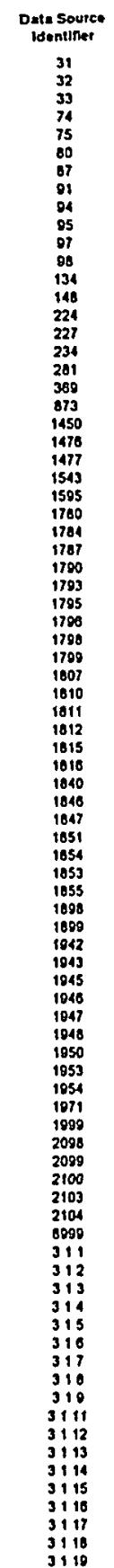

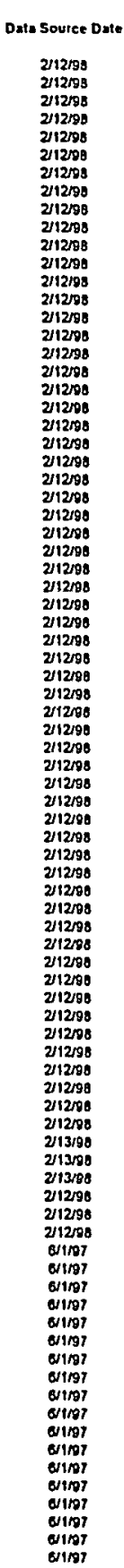

18 Dasto Reterence Intustly Partners 1997

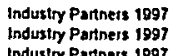

Industry Partinen 1997

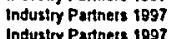

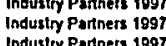

Industry Pastnees 1997

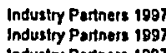
Indusily Pastnese 1997 Indusustry Portners 1098

Industry Patinese 1007 - Decommessioning Hand Methods of R Decommisstoning Hand

Decommisistibning Hand -Procedour bor

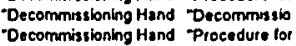
Decommissiboning Hend

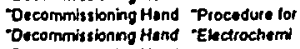

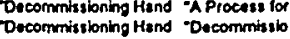
Docommissibning Hand a process tor

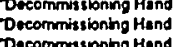

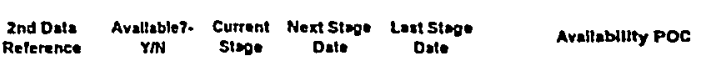

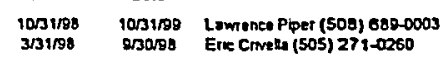

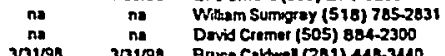

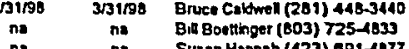

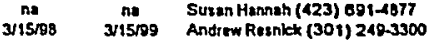

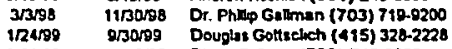

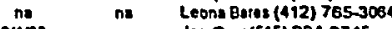

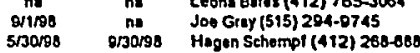

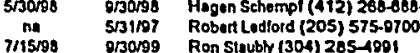

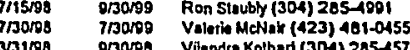
$n$ and
nat
and

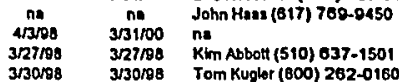

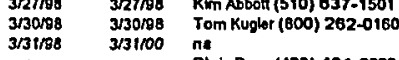

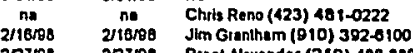

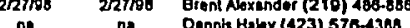

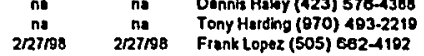

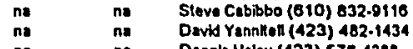

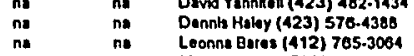
na

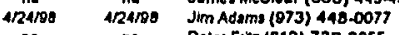

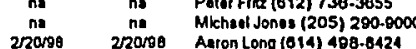

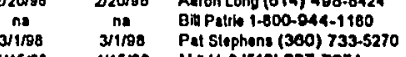

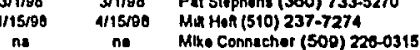

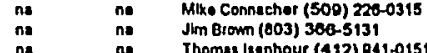

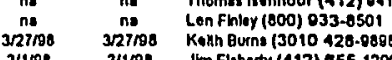

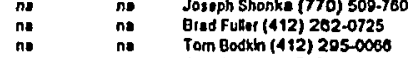

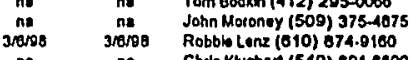

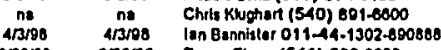

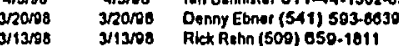

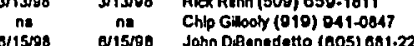
no no Date Emoro: (317) 208-7053 no no Toby Dunne (888) 273-2511

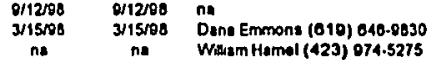

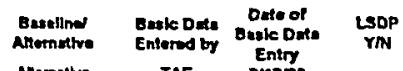

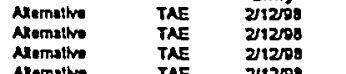

Nemelice

Metrative

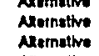

Nernalve

Nemative

Metrative

Metmaive

Metrativo

Metrative

Mrensane

Metralive

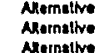

Metrnitive

Matersan:

Morstitis

Marmans:

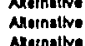

Merrative

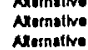

Metring

Mernative

Nestralive

Nemsilite

MAstrative

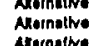

Maturative

Metrative

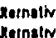

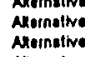

Mernotren

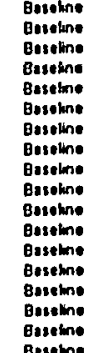


DSOL st2.1 ×13

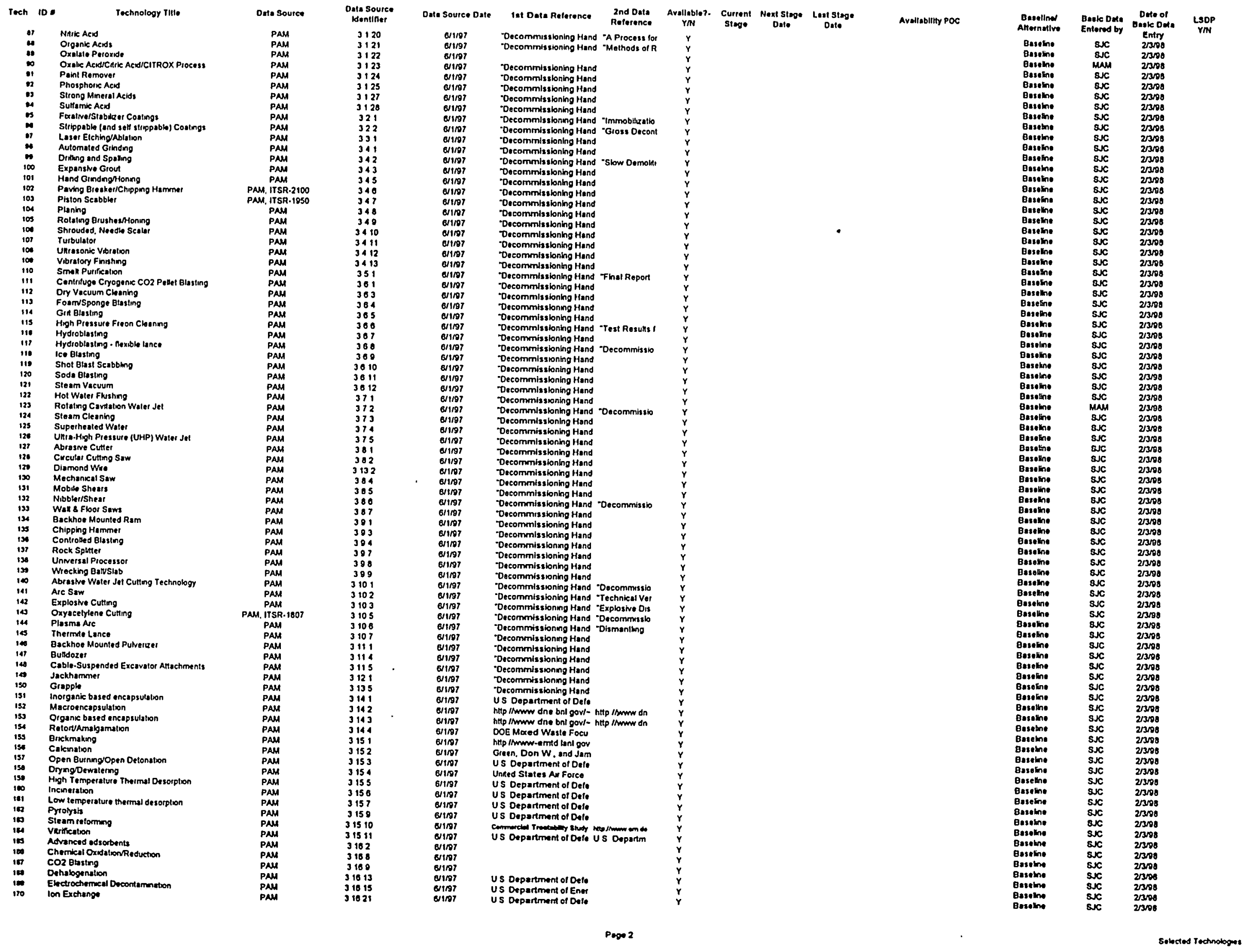


DSDLSL2-1 18/3

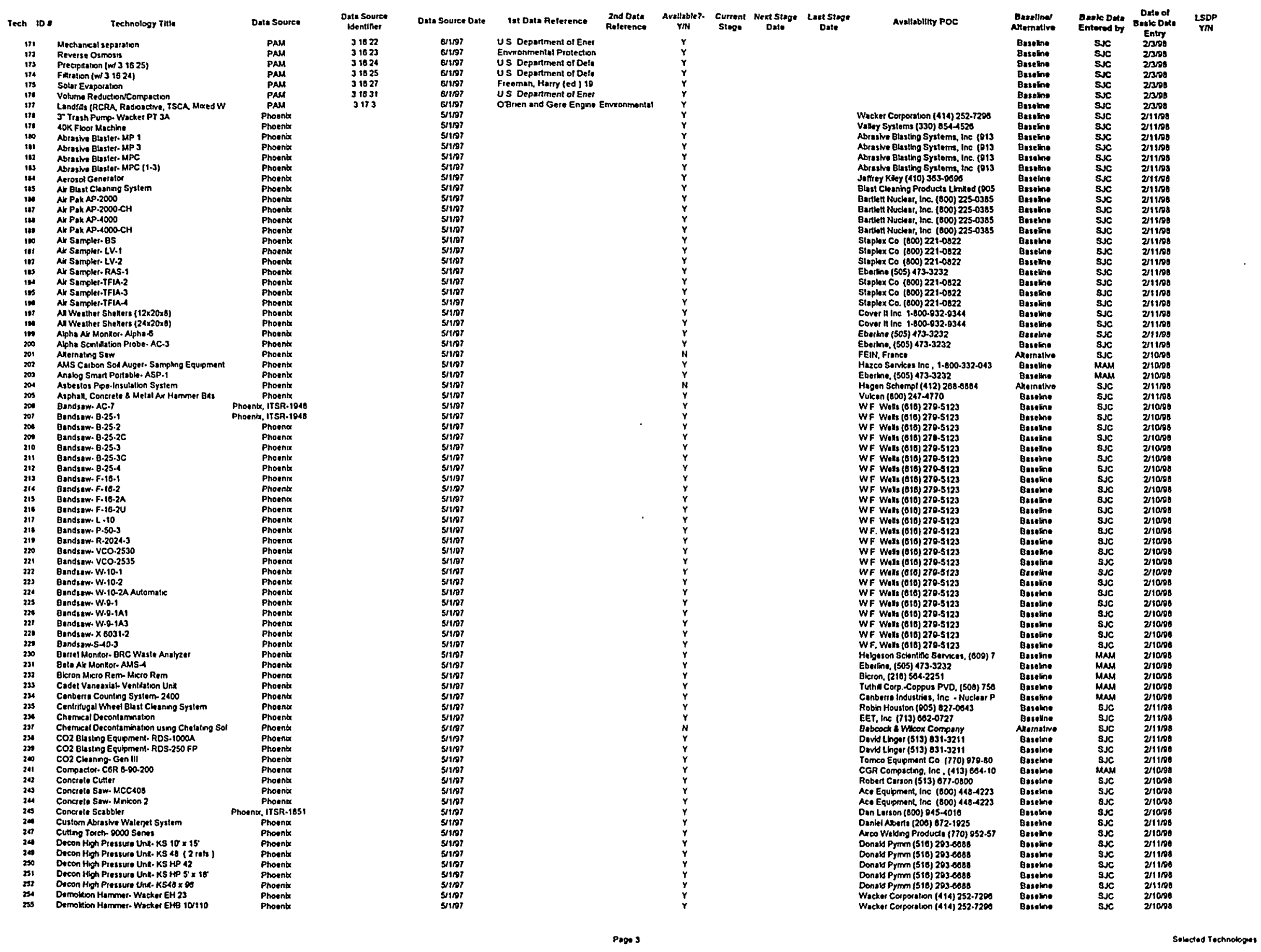




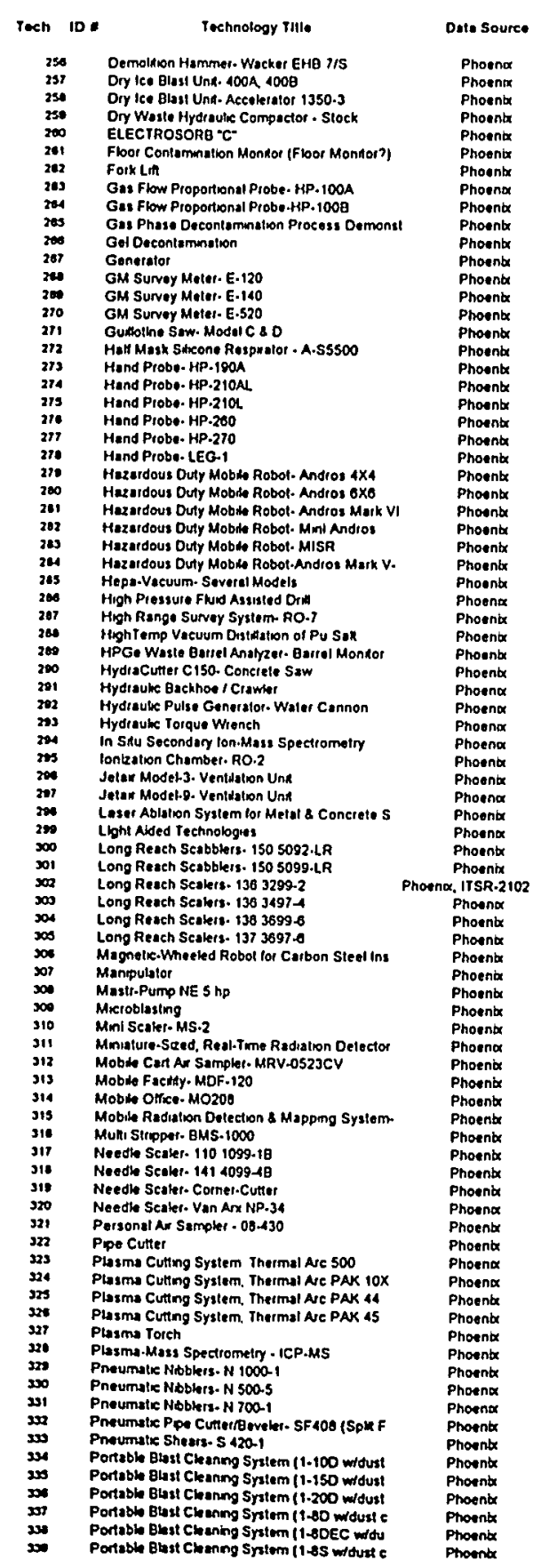

Onte Source
Identlfiner

2nd Das:
Refterence

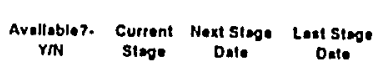

Avellebility POC

Wacker Corporstion (414) 252.7290

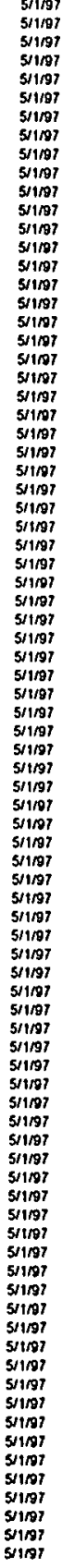

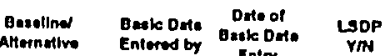

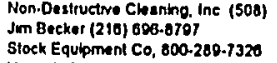

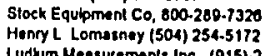

Eberthere, (5055) 173.3232

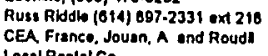

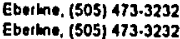

Eberthe, (1505) 473.-3232 Hazco Services inc, 1-600.-332.043

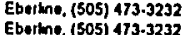

Ebortho, $(1505) 173.3232$

Ebet/fho, (1505) 173.323232

Eberthod, (505) 473-3232

Robort Perduo (423) 463.0228
Robort Parduo $(423)(433.0228$

Roberd Pardue (1423) (483.022

Robort Patduo (423) 493.022

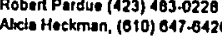

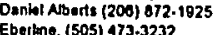

Eduardo Gorcib, (505) 687.0704

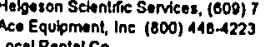

Local Rontal Co

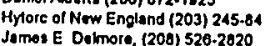
Eberthose (505) 473.-3232 526 -2020

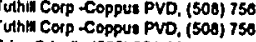
Kick Civediat (305) 271.0250 Den Lerson (800) PAS.4010 Dan Latson 1800$)$ P155-1010 Den Lesson (800) 015-1010

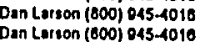

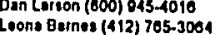

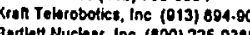

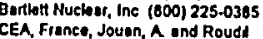
Eberims, (1505) 473.32322 Eng-Kin Soun, (516) 341.5407

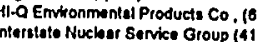

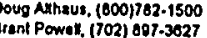
monon-Macedonste Ine (800) 550 Dan Lasison (800) 045-4018

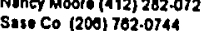

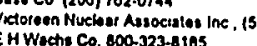

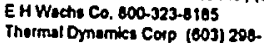
Therrmel Oy namites Corp (003) 2003.

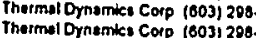
AF, Frence

Robert Houx, (515) 294.0482 Trumpt. Ine (880) 074.8220

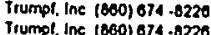
E HWachs Co $800-3232.0185$
Trumpl, ine $(800) 074.8220$ Damon Matcconsthy. Ine (800) 558 .

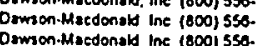

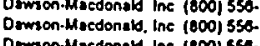




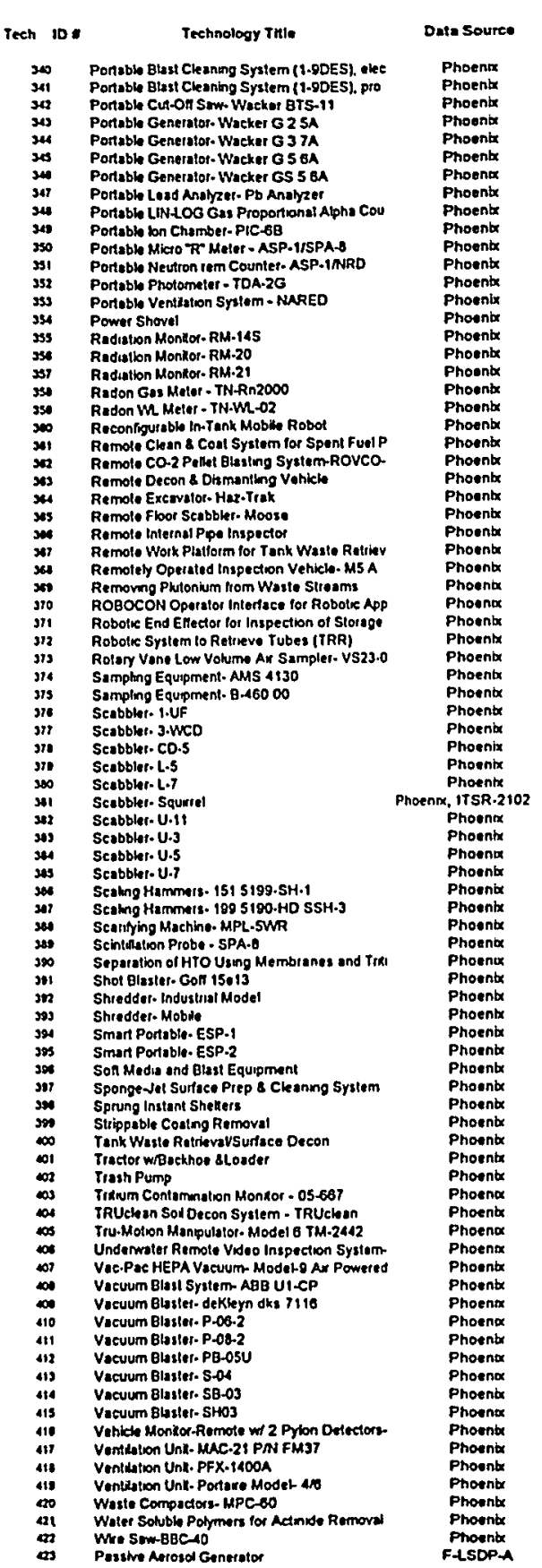

Deta Source

Dats Source Dato int Dato Reterences

2 2nd Data
Relerence.

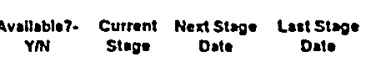

Avestebstity POC

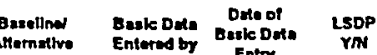

Dimzon-Mredonats. inc 18000$) 558$.

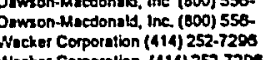

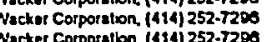

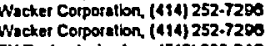
TN Terchnoboloter ine, (512) 338-010

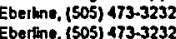
Ebertine, (505) $473-3232$ Ebertinse, (505) $473-3232$

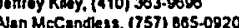

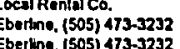
Eberhino, (505) 473-.3232

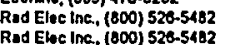
Bruce Thompeson (112) 765-3054 Ocanesering Tecthnologises (7113) 57

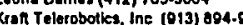
Nency Moore (1 12) 282.0725 Leona Barmes (412) 705-3004 Kran Tolie obotice, Inc. (013) 004-00

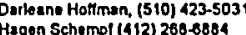
Ocerneesting Tecthologites $(713) 57$ HII-Q Emmtonmental Produdes co.

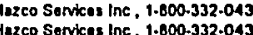

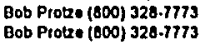

Joo Compotelofo (800) 030.3320

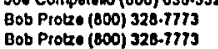

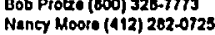
Bob Protexe (800) 320.7773

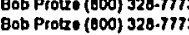

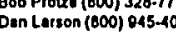

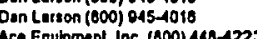

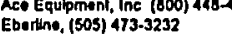

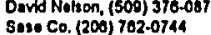
Jacobion Co. (1812) (584.8789, SS1 Shroddh ho Bystems, (503) 882 . Ebothe, (505) 473.3232

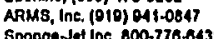
Sponge. Jot inc 800.778.8435
Micheol Dewoy, 800.528.0809 Bartiat Nuchar, Inc (800) 225.0365 Dentive Abertis (200) 072.1025 Local Rentalco

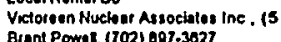

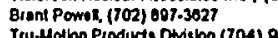

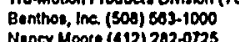

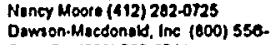

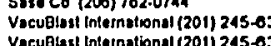

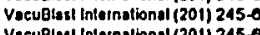
VacuBisst International (201) 245.03

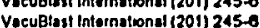
Xelex tne. (1008) 74585054 Tuthin Copp.Coppus PVD. (1508) 750 John Zmmetr, (318) 397-6165

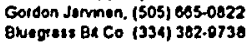

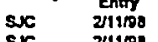

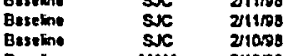

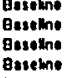

anteme

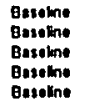

Easulno
gateme 
DEDL $112-1 \times 14$

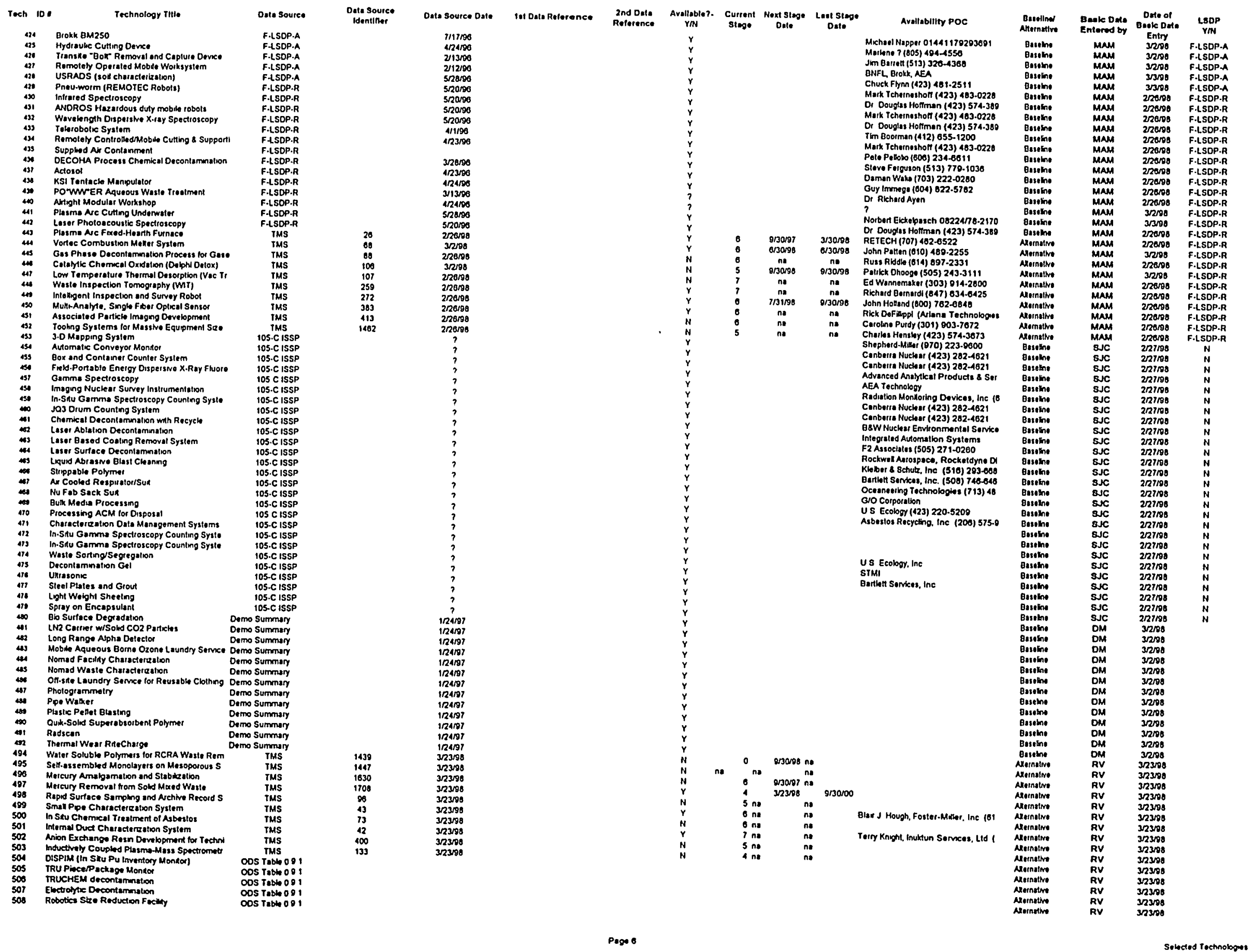


DSDL212-1 x13

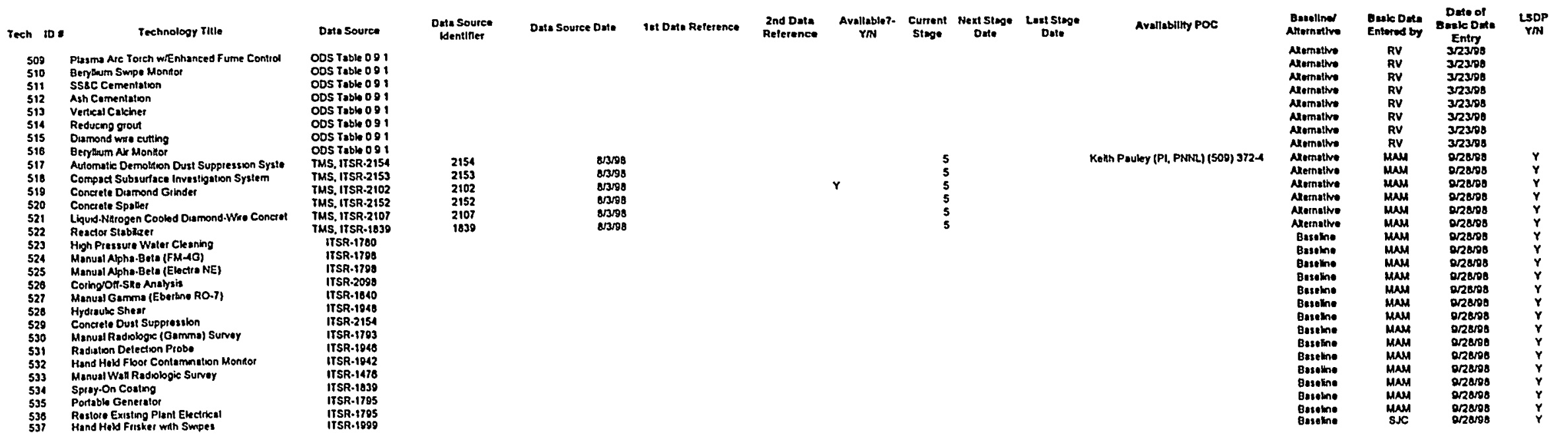


APPENDIX C

\section{A3. ECC CODES}




\begin{tabular}{|c|c|c|c|c|c|c|c|c|c|c|c|}
\hline Teeh ID & Technology Titto & Dats Source & $\begin{array}{l}\text { Data Source } \\
\text { Identifier }\end{array}$ & $\begin{array}{l}(00) \\
\text { Decommissloning } \\
\text { Categories }\end{array}$ & $\begin{array}{l}\text { (01) Material } \\
\text { Types }\end{array}$ & $\begin{array}{l}\text { (02) Process } \\
\text { Types }\end{array}$ & $\begin{array}{l}\text { (03) Process } \\
\text { Sub-Types }\end{array}$ & $\begin{array}{l}\text { (04) Condition } \\
\text { Calegories }\end{array}$ & $\begin{array}{l}\text { (05) Condition } \\
\text { Sub. } \\
\text { Categories }\end{array}$ & $\begin{array}{l}\text { Basic Data } \\
\text { Entered By }\end{array}$ & Comment \\
\hline$i$ & Portable Sensor for Hazardous Wasto & TMS & 31 & 01 & 01 & 01 & 01 & 11 & 99 & TAE & Sample acquisition system is very poorty defined \\
\hline$i$ & Portable Sensor lor Hazardous Wasto & TMS & 31 & 01 & 02 & 01 & Di & 11 & 99 & TAE & Samplo acquisitition system is very poorty defined \\
\hline 1 & Pontable Sensor for Hazardous Wasto & TMS & 31 & 01 & 03 & 01 & 01 & 11 & 99 & TAE & Sample acquisition system is very poorty defined \\
\hline 1 & Porlable Sensor for Hazardous Wasto & TMS & 31 & 01 & 01 & 01 & 01 & 12 & 99 & TAE & Sample nequisstion system is very poorly defined \\
\hline 1 & Portablo Sensor for Hazardous Wasto & TMS & 31 & 01 & 02 & 01 & 01 & 12 & 99 & TAE & Sample acquisition system is very poorty defined \\
\hline 1 & Portable Sensor lor Hazardous Wasto & TMS & 31 & 01 & 03 & 01 & 01 & 12 & 99 & TAE & Sample acquisition system ls very poorty delinod \\
\hline 1 & Porlable Sensor for Hazardous Wasto & TMS & 31 & 02 & 05 & 01 & 01 & 11 & 99 & TAE & Sample acquisision system is very poorty defined \\
\hline 1 & Portable Sensor lor Hazardous Wasto & TMS & 31 & 02 & 08 & 01 & 01 & 11 & 99 & TAE & Samplis acquislition system is very poorty defined \\
\hline$i$ & Portable Sensor lor Hazardous Wasto & TMS & 31 & 02 & 07 & 01 & 01 & 11 & 99 & TAE & Sample acquelsititon syslem is vary poorty dofinad \\
\hline$i$ & Portable Sensor lor Hazrrdous Wasto & TMS & 31 & 02 & 05 & 01 & 01 & 12 & 99 & TAE & Semplo acquistition system is very poorly defined \\
\hline$i$ & Portablo Sensor for Hazardous Wasto & TMS & 31 & 02 & D6 & 01 & of & 12 & 99 & TAE & Samplo acquisition system is vary poorty defined \\
\hline 1 & Portable Sensor for Hazardous Wasto & TMS & 31 & 02 & 07 & 01 & 01 & 12 & 99 & TAE & Samplo acquisition system is very pootty defined \\
\hline 2 & Laser Surface Cleaning & TMS & 32 & 01 & 01 & 02 & 07 & 01 & 01 & TAE & \\
\hline 2 & Laser Surface Cleaning & TMS & 32 & 01 & 01 & 02 & 07 & 02 & 01 & TAE & \\
\hline 2 & Laser Surfaco Cleaning & TMS & 32 & 01 & ot & 02 & 08 & 01 & 01 & TAE & \\
\hline 2 & Laser Surface Cleaning & TMS & 32 & 01 & 01 & 02 & 08 & 02 & 01 & TAE & \\
\hline 2 & Laser Surface Cleaning & TMS & 32 & 01 & 02 & 02 & 11 & 03 & 01 & TAE & \\
\hline 2 & Laser Surface Cleaning & TMS & 32 & 01 & 02 & 02 & 11 & 04 & 01 & TAE & \\
\hline 3 & $\begin{array}{l}\text { Interactive, Computer-Enhanced, Remoto Viewing } \\
\text { Systom }\end{array}$ & TMS & 33 & 01 & $\infty 0$ & 07 & 99 & 99 & 99 & TAE & Does not fit within PDT very well \\
\hline 4 & Pipe Explorer (TM) System & TMS & 74 & 01 & 02 & 01 & 02 & 12 & 99 & TAE & \\
\hline 4 & Pipe Explorer (TM) Systom & TMS & 74 & 01 & 02 & 01 & 02 & 11 & 99 & TAE & \\
\hline 5 & Advanced Worker Prolection System & TMS & 75 & 01 & $\infty$ & 06 & 36 & 99 & 99 & TAE & \\
\hline 6 & Stainless Steal Benoficial Reuse & TMS & 80 & 02 & 02 & 05 & 32 & 99 & 99 & TAE & \\
\hline 7 & CORPEX Nuclear Decontamination Process & TMS & 87 & 01 & 01 & 02 & 07 & 01 & 01 & TAE & \\
\hline 7 & CORPEX Nudear Decontamination Process & TMS & 87 & 01 & 01 & 02 & 07 & 02 & 01 & TAE & \\
\hline 7 & CORPEX Nudear Decontamination Process & TMS & 87 & 01 & 01 & 02 & 08 & 01 & 01 & TAE & \\
\hline 7 & CORPEX Nuclear Decontamination Process & TMS & 87 & 01 & 01 & 02 & 08 & 02 & 01 & TAE & \\
\hline 7 & CORPEX Nueloar Decontamination Process & TMS & 87 & 01 & 02 & 02 & 10 & 03 & 09 & TAE & \\
\hline 7 & CORPEX Nuclear Decontamination Process & TMS & 87 & 01 & 02 & 02 & 10 & 04 & 01 & TAE & \\
\hline 7 & CORPEX Nucloar Decontamination Process & TMS & 87 & 01 & 02 & 02 & 11 & 05 & 01 & TAE & \\
\hline 7 & CORPEX Nuclear Decontamination Process & TMS & 87 & 01 & 02 & 02 & 11 & 08 & 01 & TAE & \\
\hline 8 & $\begin{array}{l}\text { Remote-Operated Vehide, Dry Ice Pellet } \\
\text { Decontamination System }\end{array}$ & TMS & 91 & 01 & 01 & 02 & 07 & 01 & 01 & TAE & \\
\hline $\mathbf{B}$ & $\begin{array}{l}\text { Remote-Operated Vehicle, Dy I Ice Pellet } \\
\text { Pecontgmination System }\end{array}$ & TMS & 91 & 01 & 01 & 02 & 07 & 01 & 02 & TAE & \\
\hline 9 & Coherent Laser Vision System & TMS & 94 & 01 & $\infty 0$ & 07 & 89 & 99 & 99 & TAE & \\
\hline 10 & $\begin{array}{l}\text { Prolective Clohing Based on Permselective } \\
\text { Membrane and Carbon Adsorption }\end{array}$ & TMS & 85 & 01 & $\infty$ & $\infty$ & 89 & 99 & 99 & TAE & \\
\hline 11 & $\begin{array}{l}\text { Three Dimensional, Integraled Characterization } \\
\text { and Archiving System (3D-1CAS) }\end{array}$ & TMS & 97 & 01 & 01 & 01 & 01 & 11 & 99 & TAE & \\
\hline 11 & Three Dimensional, Inlegraled Characterization & TMS & 97 & 01 & 02 & 01 & 01 & 11 & 99 & TAE & \\
\hline 11 & $\begin{array}{l}\text { Three Dimensional, Integraled Characterization } \\
\text { and Arctiving System (3D.ICAS) }\end{array}$ & TMS & 97 & 01 & 03 & 01 & 01 & 11 & 99 & TAE & \\
\hline 11 & $\begin{array}{l}\text { Three Dimensional, Inlegrated Charactorization } \\
\text { and Archiving System (3D-ICAS) }\end{array}$ & TMS & 97 & 01 & 01 & 01 & 01 & 12 & 99 & TAE & \\
\hline 11 & $\begin{array}{l}\text { Three Dimensional, Integrated Characterization } \\
\text { and Archiving System (3D-1CAS) }\end{array}$ & TMS & 97 & 01 & 02 & 01 & 01 & 12 & 99 & TAE & \\
\hline 11 & $\begin{array}{l}\text { Three Dimensionat, Integrated Characterization } \\
\text { and Archiving System (3D-ICAS) }\end{array}$ & TMS & 97 & 01 & 03 & 01 & 09 & 12 & $\theta 9$ & TAE & \\
\hline 12 & Houdini: Reconfigurable in Tank Mobile Robot & TMS & 98 & 02 & 06 & 05 & 29 & 99 & 99 & TAE & \\
\hline 12 & Houdinil: Reconfigurable In Tank Mobilo Robot & TMS & 98 & 01 & $\infty$ & 07 & 99 & 89 & 99 & TAE & \\
\hline 13 & Portable X-Ray, K-Edge Heayy Metal Detector & TMS & 134 & 01 & $\infty$ & 01 & 02 & 89 & 99 & MAM & \\
\hline 14 & Asbestos Pipo-Insulation Removal System & TMS & 146 & 01 & 04 & 05 & 31 & 99 & 99 & TAE & \\
\hline 14 & Asbestos Pipo-Insulation Removal System & TMS & 148 & 01 & 04 & 05 & 29 & 89 & 98 & TAE & \\
\hline 15 & Thermal Conversion of Asbestos & TMS & 224 & 01 & 04 & 08 & 12 & 89 & 89 & TAE & \\
\hline 16 & Diagnostics and Data Fusion of Robobic Sensors & TMS & 227 & 01 & $\infty$ & 07 & 99 & 89 & 99 & TAE & \\
\hline 17 & Decontamination and Conversion of Nickel & TMS & 234 & 01 & 02 & 05 & 32 & 99 & $\theta 9$ & TAE & \\
\hline
\end{tabular}


Toch 10

Technology Titio

Decontaminatlon and Conversion of Nickol

Soda Blasting Decontamination Process

Soda Blasting Docontemination Procoss

Soda Blasting Decontaminalion Process

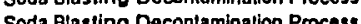

Spoctrograph

Removal of Contaminants trom Equipment and

Oobris, and Wasto Minimization Using

Romoval of Contaminants trom Equipment and

Dobris, and Wasto Minimization Using

TECHXTRACT

21 Removal of Contaminants trom Equipment and Debris, and Wasto Minimization Using$$
\text { TECHXTRAC }
$$

22 Wall Walker

TiMS Specialized Separation Uttlzing $3 \mathrm{~m}$ Membrano Technology

Decontamination of Process Equipment Using

SEG Rocyclo and Rouse of Radioactively Contaminated Scrap Metal

Spray Vacuum Cloaning

Vocloor HEPA VAC

Dual Am Work Plattom

Portabla X.Ray Fluorascence Detector

Gamma Ray Imaging (C.Reactor LSOP)

Gamma Ray Imaging (C-Reactor LSOP)

Gamma Ray Imaging (C-Rea

Moblo Ihlegraled Tomporany Uthly System

Slarboldt (rM) Flashlamp

Mobila Automated Characterization SystemiCP.5

Mobila Work System (ROSIE)

High Speed Clam Shell Cutler

Pipe Crawer (CP.5 Femald LSDPs)

Pipo Crawler (CP.5 Femald LSDPs)

Rotary Poening wh Caplive Shot

Rotary Peening with Captive Shat

Rotar Peening with Captive Shot

Rolar Peeting

Swing.Reduced Crane Control

Void Filling Using an Expanded Polyurethane

Foam Cam (TMY) Radiation Imaging System

Gamma Cam (TM) Radiation Imaging System

Gamma Cam (TM) Radiation lmaging System

Vory Fas Using Low. Densily Cellular

Oxy-Gasoline Torch (Fenald LSDP)

Centrfugat Shot Blasting

TMS

TMS

TMS

TMS
Data Source

Deta Source

(00)

(01) Material (02) Process (03) Process (04) Condition (05) Condillon

TMS
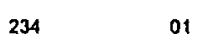

02

05

01
01
01
01
01
01
01
01
01
01

Sub.Types Categories Sub.

Basle Date Comment
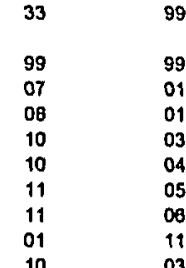

99
99
01
01
02
02
0
0
9
0

TAE

TAE

TAE

TAE

TAE

TAE

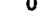

02

10

04

06

TAE

05

02

99

TAE

$\begin{array}{llllll}01 & 01 & 02 & 08 & 01 & 05\end{array}$

1478
1477
1543

01
01

$\begin{array}{ll}02 & 08 \\ 03 & 99 \\ 08 & 39\end{array}$

01
89
99

9

TAE

594

02

10

99

99

TAE

01

02

os

32

99

99

TAE 


\begin{tabular}{|c|c|c|c|c|c|c|c|c|c|c|c|}
\hline Tech ID & Technology Title & Datz Source & $\begin{array}{l}\text { Data Source } \\
\text { Identhier }\end{array}$ & $\begin{array}{c}(00) \\
\text { Decommissioning } \\
\text { Categories }\end{array}$ & $\begin{array}{l}\text { (01) Material } \\
\text { Types }\end{array}$ & $\begin{array}{l}\text { (02) Process } \\
\text { Types }\end{array}$ & $\begin{array}{l}\text { (03) Process } \\
\text { Sub-Types }\end{array}$ & $\begin{array}{l}\text { (04) Condition } \\
\text { Categories }\end{array}$ & $\begin{array}{l}\text { (05) Condltion } \\
\text { Sub. } \\
\text { Categories }\end{array}$ & $\begin{array}{l}\text { Basie Data } \\
\text { Entered By }\end{array}$ & Comment \\
\hline 48 & FRHAM-TEX Anti Contamination Suil & TMS & 1854 & 01 & oo & $\infty$ & 38 & 99 & 99 & TAE & \\
\hline 47 & Field Transportable Beta Counter Spectrometer & TMS & 1853 & 01 & 00 & 01 & 01 & 11 & 99 & TAE & \\
\hline 47 & Field Transportabio Beta Counter Spectrometor & TMS & 1853 & 01 & Do & 01 & 01 & 12 & 99 & TAE & \\
\hline 48 & Nu-Fab Anti Contamination Suit & TMS & 1855 & 01 & 00 & 06 & 38 & 99 & 99 & TAE & \\
\hline 49 & Personal tco Cooling (PIC) Systorn & TMS & 1898 & 01 & 00 & DB & 38 & 99 & 99 & TAE & \\
\hline $\mathbf{5 0}$ & Soh Media Blast Cleaning & TMS & 1899 & 01 & 01 & 02 & 07 & 01 & 01 & TAE & \\
\hline 50 & Soft Media Blast Cleaning & TMS & 1899 & 01 & 01 & 02 & 08 & 01 & 01 & TAE & \\
\hline 50 & Son Media Blast Cleaning & TMS & 1899 & 01 & 02 & 02 & 11 & 05 & 01 & TAE & \\
\hline 50 & Son Media Btast Cleaning & TMS & 1899 & 01 & 02 & 02 & 11 & $0 \theta$ & 01 & TAE & \\
\hline 52 & $\begin{array}{l}\text { Surface Contamination Monitor and Survoy } \\
\text { information Managoment System (SCWUSIMS) }\end{array}$ & TMS & 1942 & 01 & 01 & 01 & 01 & 01 & 89 & TAE & \\
\hline 53 & ROTO PEEN Scalor and VAC PAC Systom & TMS & 1943 & 09 & 01 & 02 & 07 & 01 & 01 & TAE & \\
\hline 53 & ROTO PEEN Scaler and VAC PAC System & TMS & 1943 & 01 & 01 & 02 & 07 & 02 & 01 & TAE & \\
\hline 53 & ROTO PEEN Scaler and VAC PAC System & TMS & 1943 & 01 & 01 & 02 & 08 & 01 & 01 & TAE & \\
\hline 53 & ROTO PEEN Scaler and VAC PAC Systom & TMS & 1943 & 01 & 01 & 02 & 08 & 02 & 01 & TAE & \\
\hline 53 & ROTO PEEN Scaler and VAC PAC System & TMS & 1943 & 01 & 02 & 02 & 11 & 05 & 01 & TAE & \\
\hline 53 & ROTO PEEN Scaler and VAC PAC Systom & TMS & 1943 & 01 & 02 & 02 & 11 & 08 & 01 & TAE & \\
\hline 54 & Pegasus Coating Removal (CP.5 LSDP) & TMS & 1945 & 01 & 01 & 02 & 07 & 01 & 01 & TAE & \\
\hline 54 & Pegasus Coating Removal (CP.5 LSDP) & TMS & 1945 & 01 & 01 & 02 & 07 & 02 & 01 & TAE & \\
\hline 54 & Pegasus Coating Removal (CP.5 LSDP) & TMS & 1945 & 01 & 01 & 02 & 08 & 01 & 01 & TAE & \\
\hline 54 & Pegasus Coaling Removal (CP.5 LSDP) & TMS & 1945 & 01 & 01 & 02 & 11 & 05 & 01 & TAE & \\
\hline 54 & Pegasus Coaling Removal (CP.5 LSDP) & TMS & 1945 & 01 & 02 & 02 & 11 & 06 & 01 & TAE & \\
\hline 55 & Laser Assisted Ranging and Data System (C. & TMS & 1948 & 01 & 00 & 01 & 01 & 99 & 99 & TAE & \\
\hline 56 & $\begin{array}{l}\text { Reactor LSOP) } \\
\text { System for Tracking Remodiation, Exposure, }\end{array}$ & TMS & 1947 & 01 & $\infty$ & 08 & 99 & 99 & 99 & TAE & \\
\hline & Activities and Materials (STREAM) & & 1019 & & & & & & & & ' \\
\hline 57 & Self Contained Pipe Cutting Shoar & TMS & 1948 & 01 & 02 & 03 & 99 & 99 & 99 & TAE & \\
\hline 58 & Concrete Shaving System (C.Reactor LSDP) & TMS & 1950 & 01 & 01 & 02 & 07 & 01 & 03 & TAE & \\
\hline 59 & Heat Stress Monitonng System (C.Reactor LSOP) & TMS & 1953 & 01 & 00 & $\infty$ & 35 & 99 & 99 & TAE & \\
\hline 60 & Sealod-Seam Sack Suil (C-Reactor LSDP) & TMS & 1954 & 01 & 00 & 08 & 38 & 99 & 99 & TAE & \\
\hline 64 & Advenceod Recydablo Media System (CP.5 LSDP) & TMS & 1971 & 01 & 01 & 02 & 07 & 01 & 99 & TAE & \\
\hline 61 & Advanced Reeyclablo Media System (CP.5 LSDP) & TMS & 1971 & 01 & 01 & 02 & 07 & 02 & 99 & TAE & \\
\hline 69 & Advanced Reeyclablo Media System (CP.5 LSDP) & TMS & 1971 & 01 & 01 & 02 & 08 & 01 & 99 & TAE & \\
\hline 61 & Advanced Reeyclablo Media System (CP.5 LSDP) & TMS & 1971 & 01 & 01 & 02 & 08 & 02 & 99 & TAE & \\
\hline 61 & Advanced Recyclablo Modia System (CP-5 LSDP) & TMS & 1971 & 01 & 02 & 02 & 10 & 04 & 99 & TAE & \\
\hline 62 & $\begin{array}{l}\text { Ground Based Laser Induced fluorescence } \\
\text { Imaging }\end{array}$ & TMS & 1999 & 01 & 01 & 01 & 01 & 01 & 99 & TAE & \\
\hline 63 & In Situ object Counting Systom & TMS & 2098 & 01 & 01 & 01 & 01 & 99 & 99 & MAM & \\
\hline 64 & Remote Scabbler & TMS & 2099 & 01 & 01 & 02 & 07 & 01 & 99 & MAM & \\
\hline 65 & Remole Control Concrete Demolition System & TMS & 2100 & 01 & 01 & 04 & 99 & 89 & 99 & MAM & \\
\hline 68 & RESRAD-Build & TMS & 2103 & 01 & 00 & 06 & 34 & 99 & 99 & TAE & \\
\hline 68 & RESRAD-Build & TMS & 2103 & 01 & 00 & 08 & 35 & 89 & 99 & TAE & \\
\hline 67 & Wireloss Remoto Monitoring System & TMS & 2104 & 01 & 00 & 08 & 34 & 99 & 89 & TAE & \\
\hline 67 & Wireloss Remolo Monitoring System & TMS & 2104 & 01 & $\infty$ & 08 & 35 & 99 & 89 & TAE & \\
\hline 60 & Robot Task Space Handler & TMS & 8999 & 01 & 00 & 07 & 99 & 99 & 89 & TAE & \\
\hline 69 & Acid Elcting & PAM & $3 \div 1$ & 01 & 01 & 02 & 07 & 01 & 03 & suc & polential \\
\hline 69 & Acid Etching & PAM & 3.1. & 01 & 01 & 02 & 07 & 02 & 03 & sJC & potential \\
\hline 69 & Acid Etcting & PAM & 311 & 01 & 01 & 02 & 08 & 01 & 03 & sje & potential \\
\hline 69 & Acid Etching & PAM & 311 & 01 & 04 & 02 & 08 & 02 & 03 & So & polentlal \\
\hline 69 & Acid Etching & PAM & 311 & 02 & 05 & 08 & 39 & 99 & 99 & MAM & polontial \\
\hline 69 & Acid Etching & PAM & 311 & 02 & 05 & 08 & 43 & 99 & 99 & MAM & potential \\
\hline 69 & Acid Etching & PAM & 3.11 & 02 & 05 & 08 & 99 & 99 & 99 & MAM & potential \\
\hline 70 & Acidryydrogen Peroxide Dissolution & PAM & 312 & 01 & 02 & 02 & 09 & 99 & 99 & s.sc & polontial \\
\hline $\begin{array}{l}70 \\
70\end{array}$ & 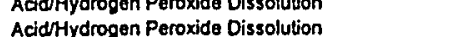 & PAM & 312 & 02 & 05 & 08 & 37 & 99 & 99 & MAM & potential \\
\hline 70 & $\begin{array}{l}\text { AcididHydrogen Peroxide Dissolution } \\
\text { AcidHon }\end{array}$ & PAM & 312 & 02 & 05 & 08 & 38 & 99 & 99 & MAM & polential \\
\hline 70 & AdidtHydrogen Peroxide Dissolution & PAM & 312 & 02 & 05 & 08 & 39 & 99 & 89 & MAM & polential \\
\hline 70 & AcidrHydragen Peroxido Dissolution & PAM & 312 & 02 & 05 & 08 & 10 & 99 & 99 & MAM & polential \\
\hline 70 & AcidHydrogen Peroxido Dissolution & PAM & 312 & 02 & 05 & 08 & 41 & 99 & 99 & MAM & polential \\
\hline 70 & Acidnydrogen Peroxide Dissolution & PAM & 312 & 02 & 05 & 08 & 43 & 99 & 99 & MAM & polential \\
\hline 70 & AcidHydrogen Peroxide Dissolution & PAM & 3.12 & 02 & 05 & 08 & 99 & 99 & 99 & MAM & potentiat \\
\hline
\end{tabular}




\begin{tabular}{|c|c|c|c|c|c|c|c|c|c|c|c|}
\hline Toch 10 & Technology Tillo & Dats Source & $\begin{array}{l}\text { Data Sourco } \\
\text { Identinar }\end{array}$ & $\begin{array}{c}100) \\
\text { Decommissloning } \\
\text { Catogorlos }\end{array}$ & $\begin{array}{l}\text { (01) Matertal } \\
\text { Types }\end{array}$ & $\begin{array}{l}\text { (02) Process } \\
\text { Types }\end{array}$ & $\begin{array}{l}\text { (03) Process } \\
\text { Sub-Types }\end{array}$ & $\begin{array}{l}\text { (04) Condition } \\
\text { Catcoorlos }\end{array}$ & $\begin{array}{l}\text { (05) Condtition } \\
\text { Sub. } \\
\text { Categories }\end{array}$ & $\begin{array}{l}\text { Basic Data } \\
\text { Entered By }\end{array}$ & Comment \\
\hline 71 & $\begin{array}{l}\text { Alkahno Pemanganate/Ammonium } \\
\text { Cltrato/EIhylenediaminotetraacetic Acid (APACE) } \\
\text { Procoss }\end{array}$ & PAM & 313 & 01 & 02 & 02 & 12 & 07 & 99 & sıc & potential \\
\hline 72 & Alkaline Salls & PAM & 314 & 02 & 05 & 08 & 38 & 99 & 99 & MAM & potential \\
\hline 72 & Alkaline Salts & PAM & 314 & 02 & 05 & 08 & 39 & 89 & 99 & MAM & potential \\
\hline 72 & Alkalino Salts & PAM & 314 & 02 & 05 & 08 & 41 & 99 & 99 & MAM & potential \\
\hline 72 & Alkatine Salts & PAM & 314 & 02 & 05 & 08 & 43 & 99 & 99 & MAM & potonlial \\
\hline 72 & Alkalino Salts & PAM & 314 & 02 & 05 & 08 & 89 & 89 & 69 & MAM & potontlat \\
\hline 73 & CAN.DECON Process & PAM & 315 & 01 & 02 & 02 & 12 & 07 & 99 & sic & polentles \\
\hline 73 & CAN.DECON Process & PAM & 3.15 & 01 & 02 & 02 & 12 & 08 & 99 & SJC & potential \\
\hline 74 & Caustic Treatment (Detergents) & PAM & 316 & 01 & 02 & 02 & 10 & 03 & 99 & SנC & probable \\
\hline 74 & Caustic Trealment (Delergents) & PAM & 318 & 01 & 02 & 02 & 11 & 05 & 02 & sJC & probable/probable \\
\hline 74 & Caustic Treatment (Detergents) & PAM & 316 & 01 & 02 & 02 & 11 & $\infty 6$ & 02 & SJC & probable/probable \\
\hline 74 & Caustic Troatment (Dotergents) & PAM & 318 & 02 & 05 & 08 & 37 & 99 & 99 & MAM & potential \\
\hline 74 & Caustic Treatment (Detergents) & PAM & 316 & 02 & 05 & 08 & 40 & 89 & 99 & MAM & polentlal \\
\hline 75 & Chelation & PAM & 317 & 01 & 01 & 02 & 07 & 01 & 03 & SAC & probabla \\
\hline 75 & Chelation & PAM & 317 & 01 & 02 & 02 & 10 & 03 & 99 & sic & potential \\
\hline 75 & Cholation & PAM & 317 & 02 & 05 & 08 & 38 & 99 & 99 & MAM & $\begin{array}{l}\text { poriential } \\
\text { potential }\end{array}$ \\
\hline 75 & Chelation & PAM & 317 & 02 & 05 & 08 & 39 & 89 & 99 & MAM & potential \\
\hline 75 & Cholalion & PAM & 317 & $\mathrm{O2}$ & 05 & 08 & 41 & 89 & 99 & MAM & polential \\
\hline 75 & Chelation & PAM & 317 & 02 & 05 & 08 & 43 & 99 & 89 & MAM & potential \\
\hline 75 & Chelation & PAM & 317 & 02 & 05 & $O B$ & 99 & 99 & 99 & MAM & potential \\
\hline 78 & Cherrical Extraction & PAM & 318 & 01 & 01 & 02 & 07 & 01 & 03 & SSC & potential \\
\hline 78 & Chemical Extraction & PAM & 318 & 01 & 01 & 02 & 07 & 01 & 04 & Suc & potential \\
\hline 76 & Chemical Extraction & PAM & 318 & 01 & 01 & 02 & 07 & 02 & 04 & SJC & potential \\
\hline 76 & Chemical Extraction & PAM & 318 & 01 & 01 & 02 & 08 & 01 & 04 & ssc & polential \\
\hline 76 & Chemical Extraction & PAM & 3.18 & 01 & 01 & 02 & 08 & 02 & 04 & sJC & potential \\
\hline 78 & Chemical Extraction & PAM & 318 & 01 & 02 & 02 & 11 & 05 & 02 & SJC & probabio/ \\
\hline 76 & Chemical Extraction & PAM & 310 & 02 & 05 & $\mathrm{OB}$ & 37 & 99 & 99 & MAM & polentlat \\
\hline 78 & Chemical Extraction & PAM & 318 & 02 & 05 & 08 & 38 & 89 & 99 & MAM & potential \\
\hline 76 & Chemical Extraction & PAM & 318 & 02 & 05 & 08 & 39 & 89 & 99 & MAM & potontisi \\
\hline 78 & Chemical Extraction & PAM & 318 & 02 & 05 & 00 & 40 & 99 & 99 & MAM & $\begin{array}{l}\text { potentibal } \\
\text { potentiol }\end{array}$ \\
\hline 78 & Chemical Extraction & PAM & 318 & 02 & 05 & 08 & 41 & 99 & 99 & MAM & potontial \\
\hline 78 & Chemical Extraction & PAM & 318 & 02 & 05 & 08 & 43 & 89 & 99 & MAM & polential \\
\hline 76 & Chemical Extraction & PAM & 318 & 02 & 05 & $O B$ & 89 & 89 & 99 & MAM & potential \\
\hline 77 & Chemical Foam/Gol & PAM & 319 & 01 & 01 & 02 & 07 & 01 & 03 & SSC & potential \\
\hline 77 & Chemical Foam/Gel & PAM & 319 & 01 & 01 & 02 & 07 & 02 & 03 & SJC & potentlal \\
\hline 77 & Chemical Foam/Gel & PAM & 3.19 & 01 & 01 & 02 & 08 & 01 & 03 & Suc & $\begin{array}{l}\text { potennal } \\
\text { polential }\end{array}$ \\
\hline 77 & Chemical FoamvGel & PAM & 319 & 01 & 01 & 02 & 08 & 02 & 03 & 2uc & $\begin{array}{l}\text { polennal } \\
\text { potential }\end{array}$ \\
\hline 77 & Chemical Foam/Gel & PAM & 319 & 01 & 02 & 02 & 10 & 03 & 99 & Ssc & probablo \\
\hline 77 & Chemical FoamGel & PAM & 319 & 02 & 05 & 08 & 37 & 89 & 99 & MAM & potential \\
\hline 77 & Chemical Foam/Gel & PAM & 319 & 02 & 05 & 08 & 38 & 99 & 99 & MAM & polential \\
\hline 77 & Chemical Foam/Gol & PAM & 319 & 02 & 05 & 08 & 39 & 89 & 99 & MAM & $\begin{array}{l}\text { polennual } \\
\text { potential }\end{array}$ \\
\hline 77 & Chemical Foam/Gel & PAM & 3.19 & 02 & 05 & 08 & 40 & 89 & 99 & MAM & potentilat \\
\hline 77 & Chemical Foam/Gel & PAM & 319 & 02 & 05 & 08 & 11 & 89 & 89 & MAM & $\begin{array}{l}\text { poletential } \\
\text { pol }\end{array}$ \\
\hline 77 & Chemical Foam/Gel & PAM & 319 & 02 & 05 & 08 & 43 & 99 & 99 & MAM & potontial \\
\hline 77 & Chemical FoamuGel & PAM & 319 & 02 & 05 & 08 & 99 & 99 & 99 & MAM & polential \\
\hline 78 & Electropolishing & PAM & 3111 & 01 & 02 & 02 & 09 & 89 & 99 & Suc & polential \\
\hline 78 & Electropolishing & PAM & 3111 & 01 & 02 & 02 & 10 & 04 & 89 & SJC & Sotential \\
\hline 78 & $\begin{array}{l}\text { Electropolishing } \\
\text { Els }\end{array}$ & PAM & 39.11 & 02 & 05 & 08 & 37 & 99 & 99 & MAM & $\begin{array}{l}\text { polendal } \\
\text { polentizi }\end{array}$ \\
\hline 78 & Electropotishing & PAM & 3111 & 02 & 05 & 08 & 38 & 89 & 99 & MAM & $\begin{array}{l}\text { polieneat } \\
\text { polentiat }\end{array}$ \\
\hline 78 & Electropolishing & PAM & 3111 & 02 & 05 & 08 & 39 & 99 & 99 & MAM & $\begin{array}{l}\text { polential } \\
\text { potential }\end{array}$ \\
\hline 78 & Electropolishing & PAM & 3911 & 02 & 05 & OB & 40 & 99 & 99 & MAM & potontial \\
\hline 78 & Electropolishing & PAM & 31.11 & 02 & 05 & 08 & 41 & 99 & 99 & MAM & polential \\
\hline 78 & Electropolishing & PAM & 31.11 & 02 & 05 & 08 & 43 & 99 & 99 & MAM & potential \\
\hline 78 & Electropolishing & PAM & 31.11 & 02 & 05 & 08 & 99 & 89 & 89 & MAM & $\begin{array}{l}\text { poternial } \\
\text { polential }\end{array}$ \\
\hline 79 & Hydrazino Nitrato & PAM & 3.1.12 & 01 & 02 & 02 & 12 & 89 & 99 & SJC & polential \\
\hline 78 & Hydrazine Nitrate & PAM & 31.12 & 02 & 05 & 00 & 39 & 99 & 99 & MAM & potontial \\
\hline 80 & Hydrochloric Acid & PAM & 3.113 & 01 & 02 & 02 & 12 & 07 & 99 & Suc & polentist \\
\hline BO & Hydrocthoric Adid & PAM & 31.13 & 01 & 02 & 02 & 12 & 08 & 99 & Suc & potential \\
\hline
\end{tabular}




\begin{tabular}{|c|c|c|c|c|c|c|c|c|c|c|c|}
\hline Tech ID & Technology Title & Data Souree & $\begin{array}{l}\text { Data Source } \\
\text { Identifier }\end{array}$ & $\begin{array}{c}(00) \\
\text { Decommissioning } \\
\text { Categories }\end{array}$ & $\begin{array}{l}\text { (01) Material } \\
\text { Types }\end{array}$ & $\begin{array}{l}\text { (02) Process } \\
\text { Types }\end{array}$ & $\begin{array}{l}\text { (03) Process } \\
\text { Sub-Types }\end{array}$ & $\begin{array}{l}\text { (10) Condition } \\
\text { Categories }\end{array}$ & $\begin{array}{l}\text { (05) Condition } \\
\text { Sub. } \\
\text { Categories }\end{array}$ & $\begin{array}{l}\text { Basic Dita } \\
\text { Entered 8y }\end{array}$ & Comment \\
\hline 80 & Hydrochloric Acid & PAM & 3.9.13 & 02 & 05 & 08 & 39 & 99 & 99 & MAM & potential \\
\hline 80 & Hydrochloric Acid & PAM & 3.1.13 & 02 & 05 & 08 & 43 & 99 & 99 & MAM & potontial \\
\hline 80 & Hydrochloric Acid & PAM & 3.1.13 & 02 & 05 & 08 & 99 & 99 & 99 & MAM & potential \\
\hline 81 & Industrial Floor Scrubbers & PAM & 3.1.14 & 01 & 01 & 02 & 07 & 01 & 03 & sJc & probablo \\
\hline 81 & Industrial Floor Scrubbers & PAM & 3.1.14 & 01 & 01 & 02 & 07 & 02 & 03 & SIC & potential \\
\hline 82 & In-Situ Electropolishing & PAM & 31.15 & 01 & 02 & 02 & 10 & 03 & 99 & SJC & potential \\
\hline 82 & In-Situ Electropolishing & PAM & 3.1.15 & 01 & 02 & 02 & 12 & 07 & 99 & SIC & potential \\
\hline 83 & Kerosene & PAM & 3.1.18 & 02 & 05 & 08 & 39 & 99 & 89 & MAM & potentlal \\
\hline 84 & Low Oxidation State Melal lon (LOMI) Procoss & PAM & 3.1.17 & 01 & 02 & 02 & 12 & 07 & 99 & SUC & potential \\
\hline 84 & Low Oxidalion State Metal Ion (LOMI) Process & PAM & 3.1.17 & 01 & 02 & 02 & 12 & 08 & 99 & SUC & potentlal \\
\hline 85 & Manual Brushing Wiping/Serubbing & PAM & 3.1.18 & 01 & 01 & 02 & 07 & 02 & 03 & sJc & polential \\
\hline 85 & Manual Brushing Wiping/Scrubbing & PAM & 3.1.18 & 01 & 01 & 02 & 08 & 02 & 03 & SNC & potential \\
\hline 88 & $\mathrm{NaOH}$ & PAM & 3.1.19 & 01 & 02 & 02 & 12 & 89 & 99 & SSC & potential \\
\hline 86 & $\mathrm{NaOH}$ & PAM & 3.1.19 & 02 & 05 & 08 & 37 & 99 & 99 & MAM & potontial \\
\hline 86 & $\mathrm{NaOH}$ & PAM & 3.1.19 & 02 & 05 & 08 & 40 & 99 & 99 & MAM & polential \\
\hline 87 & Nitric Acld & PAM & 3.120 & 01 & 02 & 02 & 12 & 99 & 99 & SJC & potontial \\
\hline 87 & Nitric Acid & PAM & 3.1.20 & 02 & 05 & 08 & 37 & 99 & 99 & MAM & potential \\
\hline 87 & Nitric Acid & PAM & 3.1 .20 & 02 & 05 & 08 & 39 & 99 & 99 & MAM & potental \\
\hline 87 & Nitric Acid & PAM & 31.20 & 02 & 05 & $O B$ & 40 & 99 & 99 & MAM & polentlal \\
\hline 88 & Organic Acids & PAM & 31.21 & 01 & 02 & 02 & 10 & 03 & 99 & SJC & potential \\
\hline 88 & Organic Acids & PAM & 3121 & 01 & 02 & 02 & 11 & 05 & 02 & SJC & potontialy \\
\hline 88 & Organic Acids & PAM & 3.121 & 02 & 05 & 08 & 38 & 99 & 99 & MAM & polentual \\
\hline 88 & Organic Acids & PAM & 31.21 & 02 & 05 & 08 & 41 & 99 & 89 & MAM & potential \\
\hline 88 & Organic Acids & PAM & 31.21 & 02 & 05 & 08 & 43 & 99 & 99 & MAM & polontlal \\
\hline $8 B$ & Organic Aclds & PAM & 3.121 & 02 & 05 & 08 & 99 & 99 & 99 & MAM & potential \\
\hline 89 & Oxalate Peroxide & PAM & 3.1 .22 & 02 & 05 & 08 & 39 & 99 & 99 & MAM & potential \\
\hline 90 & Oxalic Acid/Cithe Acid/CITROX Process & PAM & 3123 & 01 & 02 & 02 & 12 & 07 & 99 & SJC & polentlal \\
\hline 91 & $\begin{array}{l}\text { Pant Remover } \\
\text { Pallo }\end{array}$ & PAM & 3124 & 01 & 01 & 02 & 07 & 01 & 03 & SuC & probablo \\
\hline 91 & Paint Remover & PAM & 3124 & 01 & 01 & 02 & 07 & 02 & 03 & SJC & probablo \\
\hline 91 & Paint Remover & PAM & 3124 & 01 & 01 & 02 & 08 & 01 & 03 & Suc & polential \\
\hline 91 & Paint Remover & PAM & 3124 & 01 & 01 & 02 & OB & 02 & 03 & Suc & potential \\
\hline 81 & Paint Remover & PAM & 3124 & 02 & 05 & OB & 37 & 99 & 99 & MAM & potential \\
\hline 91 & Paint Remover & PAM & 3124 & 02 & 05 & OB & 40 & 99 & 99 & MAM & potenllal \\
\hline 81 & Paint Remover & PAM & 3.124 & 02 & 05 & 08 & 43 & 99 & 99 & MAM & potentlal \\
\hline 91 & Paint Remover & PAM & 3.124 & 02 & 05 & $0 B$ & 89 & 99 & 89 & MAM & polentlal \\
\hline 92 & Phosphoric Acid & PAM & 3.1 .25 & 01 & 02 & 02 & 12 & 08 & 89 & SJC & potentlal \\
\hline 93 & Strong Mineral Acids & PAM & 31.27 & 01 & 02 & 02 & 10 & 03 & 99 & SuC & potenlial \\
\hline 93 & Strong Mineral Acids & PAM & 31.27 & 01 & 02 & 02 & 11 & 05 & 02 & S.JC & polentiall \\
\hline 93 & Strong Mineral Acids & PAM & 3.1.27 & 01 & 02 & 02 & 12 & 89 & 99 & suc & potential \\
\hline 93 & Strong Mineral Acids & PAM & 3.127 & 02 & 05 & 08 & 37 & 99 & 99 & MAM & polential \\
\hline 93 & Strong Mineral Acids & PAM & 3.1 .27 & 02 & 05 & OB & 38 & 99 & 99 & MAM & potentlal \\
\hline 93 & Strong Mineral Acids & PAM & 3.1.27 & 02 & 05 & 08 & 40 & 89 & 99 & MAM & polential \\
\hline 93 & Strong Mineral Acids & PAM & 3127 & 02 & 05 & 00 & 41 & 99 & 99 & MAM & potentlal \\
\hline 94 & Sullamic Acid & PAM & 3.1.28 & 01 & 02 & 02 & 12 & 08 & 99 & SJC & potentzal \\
\hline 94 & Sultamic Acid & PAM & 31.28 & 02 & 05 & 08 & 37 & 89 & 99 & MAM & potential \\
\hline 94 & Sulfamic Acid & PAM & 3128 & 02 & 05 & 08 & 38 & 89 & 99 & MAM & potential \\
\hline 94 & Sulfamic Add & PAM & 3128 & 02 & 05 & 08 & 39 & 99 & 99 & MAM & potonlial \\
\hline 94 & Sullamic Add & PAM & 3128 & 02 & 05 & 08 & 40 & 99 & 89 & MAM & polential \\
\hline 94 & Sulfamic Acid & PAM & 31.28 & 02 & 05 & 08 & 41 & 99 & 99 & MAM & potential \\
\hline 94 & Sulfamic Adid & PAM & 3.1 .28 & 02 & 05 & 08 & 43 & 99 & 99 & maM & potential \\
\hline 94 & Sulfamic Acid & PAM & 3.1 .28 & 02 & 05 & 08 & 99 & 99 & 99 & MAM & potentiat \\
\hline 95 & Fixalive/Stabilzer Coatings & PAM & 321 & 01 & 01 & 02 & 07 & 01 & 03 & SJC & probable \\
\hline 95 & Fixative/Slabilizer Coatings & PAM & $32 i$ & 01 & 01 & 02 & 07 & 02 & 03 & SJC & potential \\
\hline 95 & Fixative/Slabilizer Coatings & PAM & 321 & 01 & 01 & 02 & 08 & 01 & 03 & SJC & potential \\
\hline & Fixative/Slabilizer Coatings & PAM & 321 & 01 & 01 & 02 & 08 & 02 & 03 & SJC & potential \\
\hline 96 & $\begin{array}{l}\text { Strippablo (and sell-strippable) Coatings } \\
\text { S }\end{array}$ & PAM & 322 & 01 & 01 & 02 & 07 & 01 & 03 & SJC & potential \\
\hline 96 & Strippable (and selli-strippable) Coatings & PAM & 322 & 01 & 01 & 02 & 07 & 02 & 03 & SJC & potental \\
\hline 98 & Strippablo (and sell-strippablo) Coatings & PAM & 322 & 01 & 01 & 02 & 08 & 01 & 03 & SJC & potential \\
\hline 96 & Strippablo (and sell-strippable) Coatings & PAM & 322 & 01 & 01 & 02 & 08 & 02 & 03 & SJC & potontial \\
\hline 97 & Laser Elcting/Ablation & PAM & 3.3.1 & 01 & 01 & 02 & 07 & 01 & 03 & SJC & polential \\
\hline
\end{tabular}


(00) (01) Materiat (02) Procoss (03) Process (04) Conditlon (05) Condilton Basle Data Comment

Automaled Grinding Automated Ginin

Dnill and Spal

Dill and Spall

Expansivo Grout

Expansive Grout

Expansiva Groul

Expansive Groul

Expansive Grout

Expansive Grout

Expansiva Grou

Expansive Grout

Hand Grindingl Honing Hammor

Paving Brakerichipping Hamm

Paving

Paving Breaker/Chrpping Hamme

Piston Scabblor

Piston Scabbler

Planing

Rotating Brushes/Honing

Rotating Brushes/Honing

Rotating Brushes/Honing

Shoded Nedro Salor

Shrouded, Needla Scalar

Turbulator

Ulirasonic Vibration

Vibratory Finishing

Smelt Purification
Smelt Purication

Centrihuge Cryogenic $\mathrm{CO} 2$ Pellet Blasting

Centituge Cryogenic CO2 Poliet Blasting

Centruga Cryogenc CO2 Pollat Blasting

Contuge Cyon

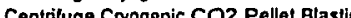

Centruge Crogenic $\mathrm{CO} 2$ Pellet Elasting

Catogorios
Identifier

Types Types Sub-Types Calegories
Sus

categories.

Entered By

Foarn/Sponge
Grit Elasting

Grit Blasting

Got Blasung

Grit Blasting

Gnt Blasting

Gnt Blasting

Grit Blasting

Grit Blasting

Gnt Elasting

Grit Blasting

Grit Blasting

Gnt Blasting

High Pressure Froon Cleaning

High Prossur Froon Cleaning

\begin{tabular}{ll} 
PAM & 341 \\
PAM & 341 \\
PAM & 342 \\
PAM & 342 \\
PAM & 343 \\
PAM & 343 \\
PAM & 343 \\
PAM & 343 \\
PAM & 343 \\
PAM & 343 \\
PAM & 343 \\
PAM & 343 \\
PAM & 343 \\
PAM & 343 \\
PAM & 343 \\
PAM & 345 \\
PAM & 346 \\
PAM & 346 \\
PAM & 346 \\
PAM & 346 \\
PAM & 347 \\
PAM & 347 \\
PAM & 347 \\
PAM & 347 \\
PAM & 348 \\
PAM & 349 \\
PAM & 349 \\
PAM & 349 \\
PAM & 3410 \\
PAM & 34.10 \\
PAM & 3410 \\
PAM & 3411 \\
PAM & 3412 \\
PAM & 3413 \\
PAM & 351 \\
PAM & 351 \\
PAM & 361 \\
PAM & 369 \\
PAM & 361 \\
PAM & 361 \\
PAM & 361 \\
PAM & 361 \\
PAM & 361 \\
PAM & 363 \\
PAM & 364 \\
PAM & 365 \\
PAM & 365 \\
PAM & 365 \\
PAM & 365 \\
PAM & 36.5 \\
PAM & 365 \\
PAM & 365 \\
PAM & 365 \\
PAM & 365 \\
PAM & 365 \\
PAM & 385 \\
PAM & 365 \\
PAM & 365 \\
PAM & 366 \\
PAM & 366 \\
& 366 \\
& \\
\hline
\end{tabular}

$\begin{array}{lll}01 & 02 & 02 \\ 01 & 02 & 02 \\ 01 & 01 & 02 \\ 01 & 01 & 02 \\ 01 & 01 & 02 \\ 01 & 01 & 02 \\ 01 & 01 & 02 \\ 01 & 01 & 02 \\ 01 & 01 & 03 \\ 01 & 01 & 03 \\ 01 & 01 & 04 \\ 01 & 01 & 04 \\ 01 & 01 & 04 \\ 01 & 01 & 04 \\ 01 & 01 & 02 \\ 01 & 01 & 02 \\ 01 & 01 & 02 \\ 01 & 01 & 02 \\ 01 & 01 & 02 \\ 01 & 01 & 02 \\ 01 & 01 & 02 \\ 01 & 01 & 02 \\ 01 & 01 & 02 \\ 01 & 02 & 02 \\ 01 & 02 & 02 \\ 01 & 02 & 02 \\ 01 & 02 & 02 \\ 01 & 01 & 02 \\ 01 & 01 & 02 \\ 01 & 01 & 02 \\ 01 & 02 & 02 \\ 01 & 02 & 02 \\ 01 & 02 & 02 \\ 01 & 02 & 02 \\ 01 & 02 & 02 \\ 01 & 01 & 02 \\ 01 & 01 & 02 \\ 01 & 02 & 02 \\ 01 & 02 & 02 \\ 01 & 02 & 02 \\ 01 & 02 & 02 \\ 01 & 02 & 02 \\ 01 & 01 & 02 \\ 01 & 02 & 02 \\ 01 & 01 & 02 \\ 01 & 01 & 02 \\ 01 & 01 & 02 \\ 01 & 02 & 02 \\ 01 & 02 & 02 \\ 01 & 02 & 02 \\ 01 & 02 & 02 \\ 01 & 02 & 02 \\ 01 & 02 & 02 \\ 01 & 02 & 02 \\ 01 & 02 & 02 \\ 02 & 05 & 08 \\ 02 & 05 & 08 \\ 01 & 01 & 02 \\ 01 & 01 & 02 \\ 01 & 01 & 02\end{array}$

\begin{tabular}{|c|c|c|c|c|}
\hline+1 & 05 & 02 & s.tc & probable/prelened \\
\hline 11 & 06 & 02 & SJC & prolerred/preferred \\
\hline 08 & 02 & 03 & SIC & potential \\
\hline 08 & 02 & 04 & SJC & potontial \\
\hline 07 & 01 & 03 & SJC & polential \\
\hline 07 & 01 & 04 & S.JC & potential \\
\hline 07 & 02 & 03 & SJC & polential \\
\hline 07 & 02 & 04 & SJC & potontist \\
\hline 14 & 99 & 99 & Suc & potontial \\
\hline 15 & 99 & 99 & S.JC & potentiat \\
\hline 23 & 99 & 99 & SJC & probablo \\
\hline 24 & 99 & 99 & S.JC & probablo \\
\hline 25 & 89 & 99 & SJC & probablo \\
\hline 28 & 99 & 99 & S.JC & probablo \\
\hline 07 & 01 & 03 & ssc & potential \\
\hline 07 & 01 & 03 & S.JC & potential \\
\hline or & 01 & 04 & SJC & potentisl \\
\hline 07 & 02 & 03 & SJC & probable \\
\hline 07 & 02 & 04 & sJc & probablo \\
\hline $\begin{array}{l}07 \\
07\end{array}$ & 01 & 03 & SJC & probable \\
\hline 07 & 01 & 04 & SJC & probabla \\
\hline 07 & 02 & 03 & suc & potential \\
\hline 07 & 02 & 04 & SJC & potential \\
\hline 09 & 99 & $\begin{array}{l}94 \\
99\end{array}$ & SJC & $\begin{array}{l}\text { porenalu } \\
\text { probale }\end{array}$ \\
\hline 12 & 07 & 99 & SJC & probable \\
\hline 12 & 08 & 99 & SJC & potential \\
\hline 12 & 99 & 99 & s.c & probable \\
\hline 07 & 02 & 03 & suc & potontial \\
\hline 08 & 01 & 03 & suc & potenvial \\
\hline 08 & 02 & 03 & SJC & probablo \\
\hline 10 & 04 & 89 & suc & potential \\
\hline 10 & $\begin{array}{l}04 \\
04\end{array}$ & 99 & s.sc & $\begin{array}{l}\text { polentual } \\
\text { potontial }\end{array}$ \\
\hline 10 & 04 & 99 & SJC & potontal \\
\hline 10 & 03 & 99 & S.JC & $\begin{array}{l}\text { polential } \\
\text { polat }\end{array}$ \\
\hline 10 & 04 & 99 & s.JC & potentlal \\
\hline 07 & 01 & 03 & Suc & polential \\
\hline 07 & 02 & 03 & sıc & polential \\
\hline 09 & 99 & 99 & SJC & probablo \\
\hline to & 03 & 99 & S.JC & $\begin{array}{l}\text { probabio } \\
\text { potentisa }\end{array}$ \\
\hline 10 & 04 & 89 & SJC & probablo \\
\hline 11 & 05 & 02 & SJC & probable/polential \\
\hline 11 & 06 & 02 & S.JC & probablo/potential \\
\hline 07 & 01 & 03 & SJC & polential \\
\hline 10 & 03 & 99 & SJC & polential \\
\hline 07 & 01 & 03 & suc & probable \\
\hline 08 & 01 & 03 & SJC & potential \\
\hline 08 & 02 & 03 & $\mathrm{suc}$ & potential \\
\hline 09 & 99 & 99 & sJc & probable \\
\hline 10 & 03 & 99 & suc & probablo \\
\hline 11 & 04 & 89 & suc & probablo \\
\hline 11 & 05 & 02 & SJC & probabiol \\
\hline 11 & $\infty$ & 02 & SJC & potentialpotential \\
\hline 12 & 07 & 99 & Sנc & probablo \\
\hline 12 & 08 & 99 & SJC & potential \\
\hline 12 & 99 & 99 & SJC & $\begin{array}{l}\text { porendal } \\
\text { probablo }\end{array}$ \\
\hline 43 & 99 & 99 & MAM & $\begin{array}{l}\text { probablo } \\
\text { probos }\end{array}$ \\
\hline 89 & 89 & 89 & MAM & polential \\
\hline 07 & 01 & 03 & Suc & potentisl \\
\hline 07 & 02 & 03 & SJC & probablo \\
\hline 08 & 01 & 03 & sJC & probsble \\
\hline
\end{tabular}




\begin{tabular}{|c|c|c|c|c|c|c|c|c|c|c|c|}
\hline Tech 10 & Technology Title & Data Source & $\begin{array}{l}\text { Dats Source } \\
\text { Identifier }\end{array}$ & $\begin{array}{l}(00) \\
\text { Decommissioning } \\
\text { Categories }\end{array}$ & $\begin{array}{l}\text { (01) Material } \\
\text { Types }\end{array}$ & $\begin{array}{l}\text { (02) Process } \\
\text { Types }\end{array}$ & $\begin{array}{l}\text { (03) Process } \\
\text { Sub-Types }\end{array}$ & $\begin{array}{l}\text { (04) Condition } \\
\text { Categories }\end{array}$ & $\begin{array}{l}\text { (05) Condition } \\
\text { Sub- } \\
\text { Calegories }\end{array}$ & $\begin{array}{l}\text { Basle Data } \\
\text { Entered By }\end{array}$ & Comment \\
\hline 115 & High Pressure Freon Cleaning & PAM & 368 & 01 & 01 & 02 & 08 & 02 & 03 & suc & probable \\
\hline 116 & Hydroblasting & PAM & 367 & 01 & 01 & 02 & 07 & 01 & 03 & SUC & probablo \\
\hline 116 & Hydroblasting & PAM & 38.7 & 01 & 01 & 02 & 07 & 02 & 03 & SJC & probablo \\
\hline 116 & Hydroblasting & PAM & 38.7 & 01 & 01 & 02 & 08 & 01 & 03 & SJC & probable \\
\hline 118 & Hydroblasting & PAM & 3.8 .7 & 01 & 01 & 02 & 08 & 02 & 03 & Suc & probable \\
\hline 116 & Hydroblasting & PAM & 38.7 & 01 & 02 & 02 & 09 & 99 & 99 & SJC & probablo \\
\hline 116 & Hydroblasting & PAM & 3.6 .7 & 09 & 02 & 02 & 10 & 03 & 99 & SIC & potential \\
\hline 116 & Hydroblasting & PAM & 3.6 .7 & 01 & 02 & 02 & 11 & 05 & 02 & SJC & $\begin{array}{l}\text { porobablot } \\
\text { pros }\end{array}$ \\
\hline 116 & Hydroblasting & PAM & 38.7 & 02 & 05 & 08 & 43 & 99 & 99 & MAM & probablio \\
\hline 116 & Hydroblasting & PAM & 36.7 & 02 & 05 & 08 & 99 & 99 & 99 & MAM & polential \\
\hline 117 & Hydroblasting - fexible lance & PAM & 3.6 .8 & or & 02 & 02 & 12 & 07 & 99 & suc & polential \\
\hline 117 & Hydroblasting - flexible lance & PAM & 3.68 & 01 & 02 & 02 & 12 & OB & 99 & Suc & probablo \\
\hline 117 & Hydroblasting - fexible lance & PAM & 3.68 & 01 & 02 & 02 & 12 & 99 & 89 & ssc & potential \\
\hline 117 & Hydroblasting - Raxibla lanco & PAM & 3.6 .8 & 02 & 05 & 08 & 43 & 99 & 99 & MAM & probable \\
\hline 117 & Hydroblasting - noxibto tanco & PAM & 3.6 .8 & 02 & 05 & OB & 99 & 99 & 89 & MAM & potential \\
\hline 198 & 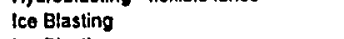 & PAM & 389 & 01 & 01 & 02 & 07 & 01 & 03 & SJC & potential \\
\hline 118 & Ice Blasting & PAM & 3.69 & 01 & 01 & 02 & 07 & 02 & 03 & sJc & potential \\
\hline 118 & Ieo Elasting & PAM & 36.9 & 01 & 01 & 02 & 08 & 01 & 03 & SJC & potential \\
\hline 198 & leo Blasting & PAM & 36.9 & 01 & 01 & 02 & 08 & 02 & 03 & SJC & polential \\
\hline 118 & leo Blasting & PAM & 36.9 & 01 & 02 & 02 & 10 & 03 & 89 & SJC & polential \\
\hline 118 & Ico Elasting & PAM & 3.69 & 01 & 02 & 02 & 11 & 05 & 02 & Suc & potential/potential \\
\hline 118 & Ico Blasting & PAM & 3.69 & 01 & 02 & 02 & 11 & 08 & 02 & SJC & polentiaupotential \\
\hline 118 & Ico Blasting & PAM & 3.68 & 02 & 05 & 00 & 43 & 99 & 99 & MAM & $\begin{array}{l}\text { probablo } \\
\text { poitenial }\end{array}$ \\
\hline 118 & Ice Blasting & PAM & 3.8.9 & 02 & 05 & 00 & 99 & 89 & 89 & MAM & $\begin{array}{l}\text { probablo } \\
\text { potential }\end{array}$ \\
\hline 119 & Shot Blast Scabbling & PAM & 36.10 & 01 & 01 & 02 & 07 & 01 & 03 & SJC & $\begin{array}{l}\text { polential } \\
\text { probable }\end{array}$ \\
\hline 119 & Shot Blast Scabbling & PAM & 38.10 & 01 & 02 & 02 & 11 & 05 & 02 & SJC & $\begin{array}{l}\text { probabio } \\
\text { probablof }\end{array}$ \\
\hline 119 & Shol Blast Scabbling & PAM & 3810 & 02 & 05 & OB & 43 & 99 & 99 & MAM & probablo \\
\hline 119 & Shat Blast Scabbling & PAM & 3610 & 02 & 05 & 08 & 99 & 99 & 99 & MAM & potontlal \\
\hline 120 & Soda Blasting & PAM & 38.11 & 01 & 01 & 02 & 07 & 02 & 03 & SUC & potential \\
\hline 120 & Soda Blasting & PAM & 3611 & 01 & 01 & 02 & 08 & 01 & 03 & SuC & potontlal \\
\hline 120 & Soda Blasting & PAM & 3611 & 01 & 01 & 02 & 08 & 02 & 03 & SJC & $\begin{array}{l}\text { polonal } \\
\text { polontal }\end{array}$ \\
\hline 120 & Soda Blasting & PAM & 3811 & 02 & 05 & 08 & 43 & 99 & 99 & MAM & $\begin{array}{l}\text { polctinal } \\
\text { probablo }\end{array}$ \\
\hline 120 & Soda Blasling & PAM & 3811 & 02 & 05 & 08 & 99 & 99 & 99 & MAM & $\begin{array}{l}\text { probable } \\
\text { polentlal }\end{array}$ \\
\hline 121 & Steam Vacuum & PAM & 36.12 & 01 & 01 & 02 & 07 & of & 03 & SJC & $\begin{array}{l}\text { potenulal } \\
\text { polentlal }\end{array}$ \\
\hline 121 & Steam Vacuum & PAM & 36.12 & 01 & 01 & 02 & 07 & 02 & 03 & SJC & potential \\
\hline 121 & Sloam Vacuum & PAM & 3612 & 01 & 01 & 02 & 08 & 01 & 03 & SJC & potential \\
\hline 121 & Sleam Vacuum & PAM & 3012 & 01 & 01 & 02 & 08 & 02 & 03 & SUC & potental \\
\hline 121 & Sleam Vacuum & PAM & 36.12 & 02 & 05 & 08 & 43 & 99 & 99 & MAM & probable \\
\hline 129 & Sleam Vacuum & PAM & 36.12 & 02 & 05 & 08 & 99 & 99 & 89 & MAM & polentiat \\
\hline 122 & Hol Water Flushing & PAM & 37.1 & 02 & 05 & $0 B$ & 43 & 89 & 99 & MAM & probablo \\
\hline 122 & Hol Water Flushing & PAM & 37.1 & 02 & 05 & 08 & B9 & 99 & 89 & MAM & polential \\
\hline 123 & Rotating Cavitation Water Jet & PAM & 372 & 01 & 02 & 02 & 12 & 07 & 89 & SJC & probablo \\
\hline 123 & Rotating Cavitation Water Jet & PAM & 372 & 01 & 02 & 02 & 12 & 08 & 99 & suc & probsble \\
\hline 123 & Rotating Cavitation Water Jet & PAM & 37.2 & 01 & 02 & 02 & 12 & 99 & 89 & SIC & probablo \\
\hline 123 & Rotating Cavitation Waler Jet & PAM & 372 & 02 & 05 & 08 & 43 & 99 & 99 & MAM & probablo \\
\hline 123 & Rotating Cavitation Water Jet & PAM & 3.72 & 02 & 05 & 08 & 89 & 99 & 99 & MAM & potential \\
\hline 124 & Steam Cleaning & PAM & 37.3 & 04 & 01 & 02 & 07 & 02 & 03 & SJC & potendisi \\
\hline 124 & Sleam Cleaning & PAM & 37.3 & 01 & 01 & 02 & 00 & 01 & 03 & Suc & polentlal \\
\hline 124 & Steam Cleaning & PAM & $\begin{array}{l}373 \\
373\end{array}$ & 01 & 01 & 02 & 08 & 02 & 03 & SJC & potential \\
\hline 124 & Sleam Cleaning & PAM & 373 & 01 & 02 & 02 & 10 & 03 & 99 & SUC & potontisal \\
\hline 124 & Stoam Cleaning & PAM & 373 & 02 & 05 & 08 & 43 & 89 & 89 & MAM & probable. \\
\hline 124 & Sleam Cleaning & PAM & 3.73 & 02 & 05 & 08 & 99 & 89 & 98 & MAM & potentlial \\
\hline 125 & Supetheated Water & PAM & 3.7 .4 & 01 & 01 & 02 & 07 & 01 & 03 & SJC & potential \\
\hline 125 & Superheated Water & PAM & 374 & 01 & 01 & 02 & 07 & 02 & 03 & SJC & potential \\
\hline 125 & Superheated Water & PAM & 37.4 & 01 & 01 & 02 & 08 & 01 & 03 & SJC & potontial \\
\hline 125 & Superheated Water & PAM & 3.74 & 01 & 01 & 02 & 08 & 02 & 03 & SJC & potential \\
\hline 125 & Superteated Water & PAM & 37.4 & 02 & 05 & 08 & 43 & 89 & 99 & MAM & probable \\
\hline 125 & Supertiested Water & PAM & 37.4 & 02 & 05 & 08 & 89 & 99 & 99 & MAM & potential \\
\hline 128 & Utro. High Pressure (UHP) Water Jot & PAM & 37.5 & 01 & 01 & 02 & 07 & 01 & 04 & SJC & potontial \\
\hline 126 & Ultua. High Pressuro (UHP) Water Jot & PAM & 375 & 01 & 01 & 02 & 07 & 02 & 04 & SuC & potential \\
\hline
\end{tabular}




\begin{tabular}{|c|c|c|c|c|c|c|c|c|c|c|c|}
\hline Toch & Technology THIO & Datu Source & $\begin{array}{l}\text { Dala Source } \\
\text { Identifier }\end{array}$ & $\begin{array}{c}(00) \\
\text { Decommissioning } \\
\text { Calegories }\end{array}$ & $\begin{array}{l}\text { (01) Malertal } \\
\text { Types }\end{array}$ & $\begin{array}{l}\text { (02) Procoss } \\
\text { Typos }\end{array}$ & $\begin{array}{l}\text { (D)\} Process: } \\
\text { Sub-Typos }\end{array}$ & $\begin{array}{l}\text { (04) Condition } \\
\text { Categortos }\end{array}$ & $\begin{array}{l}\text { (05) Conditton } \\
\text { Sub. } \\
\text { Calogories }\end{array}$ & $\begin{array}{l}\text { Basic Data } \\
\text { Entered By }\end{array}$ & Comment \\
\hline 128 & Ullra-High Prossure (UHP) Water Jot & PAM & 375 & 01 & 01 & 02 & 08 & 01 & 04 & suc & potential \\
\hline 128 & Ullira-High Prossuro (UHP) Wator Jal & PAM & 375 & 01 & 01 & 02 & 08 & 02 & 04 & SJC & polential \\
\hline 126 & Ulira-High Pressure (UHP) Walor Jet & PAM & 375 & 01 & 02 & 02 & 09 & 99 & 99 & SJC & probable \\
\hline 128 & Ullira.High Pressure (UHP) Water Jot & PAM & 375 & 01 & 02 & 02 & 10 & 03 & 99 & sJc & potential \\
\hline 128 & Ultra-High Pressuro (UHP) Water Jot & PAM & 375 & 01 & 02 & 02 & 11 & 05 & 02 & SJC & probable/potential \\
\hline 128 & Ulltra.High Pressure (UHP) Water Jat & PAM & 37.5 & 09 & 02 & 02 & 11 & 06 & 02 & SJC & polentiavpotential \\
\hline 128 & Ulira-High Prossuro (UHP) Wator Jot & PAM & 3.75 & 02 & 05 & 08 & 43 & 99 & 99 & MAM & probablo \\
\hline 128 & Utra. High Prossure (UHP) Wator Jat & PAM & 375 & 02 & 05 & 08 & 99 & 99 & 99 & MAM & potential \\
\hline 127 & - Abrasive Cuttor & PAM & 301 & 01 & 02 & 03 & 98 & 10 & 99 & suc & potential \\
\hline $\begin{array}{l}127 \\
127\end{array}$ & Abrasive Cutter & PAM & $38 i$ & 01 & 02 & 03 & 17 & 10 & 89 & SJC & prelorred \\
\hline 127 & Abrasivo Cutter & PAM & 301 & 01 & 02 & 03 & 98 & 10 & 99 & SJC & potential \\
\hline 128 & Cireular Cutting Saw & PAM & 382 & 01 & 02 & 03 & 17 & 10 & 99 & SJC & potential \\
\hline 128 & Circular Cutting Saw & PAM & 382 & 01 & 02 & 03 & 18 & 10 & 99 & SJC & probable \\
\hline 128 & Cireular Cutting Saw & PAM & 382 & 01 & 02 & 03 & 19 & 10 & 99 & SJC & potenual \\
\hline 128 & Circular Cutting Saw & PAM & 382 & 01 & 01 & 03 & 99 & 99 & 99 & MAM & \\
\hline 129 & Diamono Wiro & PAM & 3.132 & 01 & 01 & 04 & 22 & 99 & 99 & SUC & potential \\
\hline 129 & Diamond Wiro & PAM & 3132 & 01 & 01 & 04 & 23 & 99 & 99 & Suc & probabla \\
\hline $\begin{array}{l}129 \\
129 \\
-120\end{array}$ & Diamond Wiro & PAM & 3132 & 01 & 01 & 04 & 24 & 99 & 99 & SJC & probable \\
\hline 129 & Diamond Wiro & PAM & 3132 & 01 & 02 & 04 & 27 & 99 & 99 & SIC & potential \\
\hline 129 & Diamond Wiro & PAM & 3132 & 01 & 02 & 04 & 28 & 99 & 89 & SJC & potential \\
\hline 129 & Diamond Wiro & PAM & 3132 & 01 & 01 & 03 & 99 & 99 & 99 & MAM & \\
\hline 130 & Mechanical Saw & PAM & 384 & 01 & 02 & 03 & 17 & 10 & 99 & suc & potentlal \\
\hline 130 & Mechanical Saw & PAM & 384 & 01 & 02 & 03 & 18 & 10 & 99 & SJC & probablo \\
\hline 130 & Mechanical Saw & PAM & 384 & 01 & 02 & 03 & 19 & 10 & 99 & SuC & polential \\
\hline 131 & Mobile Shears & PAM & 385 & 01 & 02 & 03 & 18 & 10 & 99 & SJC & probable \\
\hline 131 & Mobilo Shears & PAM & 385 & 01 & 02 & 03 & 17 & 10 & 99 & SJC & potential \\
\hline 131 & Mobile Shears & PAM & 385 & 01 & 02 & 03 & 18 & 10 & 99 & SJC & probablo \\
\hline 131 & Mobile Shears & PAM & 385 & 01 & 02 & 03 & 19 & 10 & 99 & SJC & potential \\
\hline 131 & Mobile Shears & PAM & 385 & 01 & 01 & 04 & 22 & 99 & 89 & SJC & polential \\
\hline 131 & Mobile Shears & PAM & 385 & 01 & 01 & 04 & 23 & 99 & 99 & SJC & probabio \\
\hline $\begin{array}{l}131 \\
131\end{array}$ & Mobilo Shears & PAM & 385. & 01 & 01 & 04 & 24 & 99 & 89 & SJC & potential \\
\hline 131 & Mobile Shears & PAM & 385 & 01 & 01 & 04 & 20 & 99 & 99 & Ssc & potential \\
\hline 131 & Mobile Shears & PAM & 385 & 01 & 02 & 04 & 28 & 99 & 89 & SJC & probable \\
\hline 131 & Moblo Shears & PAM & 385 & 01 & 03 & 04 & 27 & 99 & 99 & sJC & potontial \\
\hline 131 & Mobile Shears & PAM & 385 & 01 & 03 & 04 & 28 & 89 & 99 & SJC & probable \\
\hline 132 & Nibbler/Shear & PAM & 388 & 01 & 02 & 03 & 18 & 10 & 99 & SJC & probable \\
\hline 132 & Nibbler/Shear & PAM & 386 & 01 & 02 & 03 & 17 & 10 & 89 & SJC & probable \\
\hline 132 & Nibbler/Shear & PAM & 380 & 01 & 02 & 03 & 18 & 10 & 99 & SJC & probable \\
\hline 132 & Nibbler/Shear & PAM & 386 & 01 & 02 & 03 & 19 & 10 & 99 & suc & potential \\
\hline 133 & Wall \& Floor Saws & PAM & 387 & 01 & 01 & 03 & 14 & 99 & 99 & Suc & potontlal \\
\hline 133 & Wall \& Floor Saws & PAM & 387 & 01 & 01 & 03 & 15 & 99 & 89 & SJC & probablo \\
\hline 133 & Wall \& Floor Saws & PAM & 387 & 01 & 01 & 04 & 23 & 99 & 99 & suc & potential \\
\hline 133 & Wall \& Floor Saws & PAM & 387 & 01 & 01 & 04 & 24 & 99 & 99 & suc & potential \\
\hline 133 & Wall \& Floor Saws & PAM & 387 & 01 & 03 & 04 & 28 & 99 & 99 & sJC & probable \\
\hline 134 & Backhoo Mounted Ram & PAM & 3.91 & 01 & 01 & 03 & 13 & 99 & 99 & S.JC & probable \\
\hline 134 & Backhoe Mounled Rarn & PAM & 391 & 01 & 01 & 03 & 14 & 89 & 99 & Ssc & prolerred \\
\hline 134 & Backhoe Mounted Ram & PAM & 399 & 01 & 01 & 03 & 15 & 99 & 99 & S.JC & probablo \\
\hline 134 & Backhoe Mounled Ram & PAM & 391 & 01 & 01 & 04 & 22 & 99 & 99 & suc & probablo \\
\hline 134 & Backhoe Mounled Ram & PAM & 391 & 01 & or & 04 & 23 & 99 & 99 & SJC & probsblo \\
\hline 134 & Backhoo Mountod Ram & PAM & 39.1 & 01 & 01 & 04 & 24 & 99 & 99 & Suc & preferred \\
\hline 134 & Backhoe Mounled Ram & PAM & 3.8 .1 & 01 & 01 & 04 & 25 & 99 & 99 & SJC & polential \\
\hline $\begin{array}{l}134 \\
134\end{array}$ & Backhoo Mounted Ram & PAM & $\begin{array}{l}3.0 .1 \\
391\end{array}$ & 01 & 01 & 04 & 20 & 99 & 99 & SIC & probablo \\
\hline 134 & Backhoo Mounled Rarn & PAM & 391 & 01 & 02 & 04 & 27 & 99 & 99 & SJC & polontial \\
\hline 134 & Backhoo Mounled Ram & PAM & 391 & 01 & 02 & 04 & 28 & 99 & 99 & sJC & potential \\
\hline 134 & Backhoo Mounted Ram & PAM & 3.91 & 09 & 03 & 04 & 27 & 99 & 99 & SJC & probatio \\
\hline 134 & Backhoo Mountod Ram & PAM & 391 & 01 & 03 & 04 & 28 & 99 & 99 & suc & probable \\
\hline 135 & Chipping Hammer & PAM & 393 & 01 & 09 & 03 & 15 & 99 & 99 & Suc & polential \\
\hline 138 & & PAM & 394 & 01 & 01 & 03 & 14 & 89 & 99 & ssc & polontial \\
\hline 138 & Controlled Blasting & PAM & 384 & 01 & 09 & 04 & 22 & 99 & 99 & suc & polential \\
\hline 138 & Controted Blasting & PAM & 3.94 & 01 & 01 & 04 & 23 & 99 & 99 & suc & potontial \\
\hline
\end{tabular}




\begin{tabular}{|c|c|c|c|c|c|c|c|c|c|c|c|}
\hline Tech ID & Technology Tule & Data Source & $\begin{array}{l}\text { Data Source } \\
\text { Identifier }\end{array}$ & $\begin{array}{c}(00) \\
\text { Decommissioning } \\
\text { Calegories }\end{array}$ & $\begin{array}{c}\text { (01) Material } \\
\text { Types }\end{array}$ & $\begin{array}{l}\text { (02) Process } \\
\text { Types }\end{array}$ & $\begin{array}{l}\text { (03) Process } \\
\text { Sub-Types }\end{array}$ & $\begin{array}{l}\text { (04) Condition } \\
\text { Categories }\end{array}$ & $\begin{array}{l}\text { (05) Condition } \\
\text { Sub- } \\
\text { Categories }\end{array}$ & $\begin{array}{l}\text { Basle Data } \\
\text { Entered By }\end{array}$ & Comment \\
\hline 136 & Controlied Blasting & PAM & 3.9 .4 & 01 & 01 & 04 & 24 & 99 & 99 & suc & polential \\
\hline 136 & Controlled Blasting & PAM & 3.9.4 & 01 & 09 & 04 & 25 & 99 & 99 & SJC & potential \\
\hline 136 & Controlled Blasting & PAM & 3.9 .4 & 01 & 09 & 04 & 28 & 99 & 99 & ssc & potential \\
\hline 137 & Rock Splitter & PAM & 3.9 .7 & 01 & 01 & 04 & 22 & 99 & 99 & suc & potential \\
\hline 137 & Rock Splittor & PAM & 3.9 .7 & 01 & 01 & 04 & 23 & 99 & 99 & sJc & potential \\
\hline 137 & Rock Splitter & PAM & 39.7 & 01 & 01 & 04 & 24 & 99 & 99 & Ssc & potential \\
\hline 137 & Rock Splittor & PAM & 3.9 .7 & 01 & 01 & 04 & 25 & 99 & 99 & sJc & potential \\
\hline 138 & Universal Processor & PAM & 3.88 & 01 & 01 & 03 & 14 & 99 & 99 & SJC & potential \\
\hline 138 & - Universal Procossor & PAM & 3.9 .8 & $0 t$ & of & 03 & 15 & 99 & 99 & SJC & potental \\
\hline 139 & Wrecking BaluSlab & PAM & 3.8 .9 & 01 & 01 & 03 & 13 & 99 & 99 & SJC & potential \\
\hline 139 & Wrecking Ball/slab & PAM & 3.9 .9 & 01 & 01 & 03 & 14 & 99 & 99 & sJc & polential \\
\hline 139 & Wrocking Ballusiab & PAM & 3.9 .9 & 01 & 01 & 03 & 15 & 89 & 99 & sJc & probablo \\
\hline 139 & Wrecking BaluSlab & PAM & 3.9 .9 & 01 & 01 & 04 & 23 & 89 & 99 & SJC & probable \\
\hline 139 & Wrecking BaluSlab & PAM & 3.9.9 & 01 & 01 & 04 & 24 & 99 & 89 & sJc & probable \\
\hline 139 & Wrocking Ball/Slab & PAM & 3.9 .9 & 01 & 01 & 04 & 25 & 99 & 99 & SJC & potential \\
\hline 139 & Wrecking BatuSlab & PAM & 3.9 .9 & 01 & 01 & 04 & 28 & 99 & 89 & ssc & preferred \\
\hline 139 & Wrecking Baluslab & PAM & $\mathbf{3 . 9 . 9}$ & 01 & 02 & 04 & 27 & 99 & 99 & SJC & polential \\
\hline 140 & Abrasive Water Jel Cultino Technology & PAM & 3.10 .1 & 01 & 02 & 03 & 17 & 10 & 99 & SJC & probable \\
\hline 141 & Arc Saw & PAM & 3102 & 01 & 02 & 03 & 17 & 09 & 99 & SJC & potential \\
\hline $14 t$ & Arc Saw & PAM & 3.102 & 01 & 02 & 03 & 18 & 09 & 99 & SJC & probable \\
\hline 141 & Arc Saw & PAM & 3.102 & 01 & 02 & 03 & 19 & 09 & 99 & SJC & probable \\
\hline 142 & Explosive Culting & PAM & 3.103 & 01 & 01 & 03 & 14 & 89 & 99 & SJC & potential \\
\hline 142 & Explosive Cutting & PAM & 3103 & 01 & 02 & 04 & 27 & 99 & 99 & SJC & potential \\
\hline 142 & Explosive Cutting & PAM & 3.103 & 01 & 02 & 04 & $2 \theta$ & 99 & 99 & SJC & potentlal \\
\hline 143 & Oxyacelylene Cutting & PAM & 3105 & 01 & 02 & 03 & 16 & 09 & 99 & sJc & probablo \\
\hline 143 & Oxyacelyleno Cutting & PAM & 3.105 & 01 & 02 & 03 & 17 & 09 & 99 & suc & probablo \\
\hline 143 & Oxyacetylone Cutting & PAM & 3.105 & 01 & 02 & 03 & 18 & 00 & 99 & SJC & probable \\
\hline 143 & Oxyacelylene Cutting & PAM & 3105 & 01 & 02 & 03 & 19 & 09 & 99 & sJC & probablo \\
\hline 144 & $\begin{array}{l}\text { Plasma Arc } \\
\text { nath }\end{array}$ & PAM & 3.108 & 01 & 02 & 03 & 18 & 09 & 99 & SNC & potontral \\
\hline 144 & Plasma Arc & PAM & 3.106 & 01 & 02 & 03 & 17 & 09 & 99 & s.c & probable \\
\hline 144 & Plasme Arc & PAM & 3.106 & 01 & 02 & 03 & 10 & 09 & 89 & SJC & potential \\
\hline 144 & Plasma Are & PAM & 3106 & 01 & 02 & 03 & 10 & 09 & 89 & SJc & probable \\
\hline 145 & Themite Lance & PAM & 310.7 & 01 & 02 & 03 & 17 & 09 & 99 & SJC & potontlal \\
\hline 145 & Therrite Lanco & PAM & 3.107 & 01 & 02 & 03 & 19 & 09 & 99 & SJC & probablo \\
\hline 146 & Backhoo Mounted Pulverizer & PAM & 311.1 & 01 & 01 & 04 & 22 & 99 & 98 & Suc & polontial \\
\hline 146 & Backhoo Mounted Pulverizer & PAM & 3.11 .1 & 01 & 01 & 04 & 23 & 99 & 89 & SJC & potential \\
\hline 146 & Backhoo Mounted I & PAM & 3.11 .1 & 01 & 01 & 04 & 24 & 89 & 99 & sJc & potential \\
\hline 146 & Backhoo Mounted Pulverizer & PAM & 3.111 & 01 & 01 & 04 & 25 & 99 & 98 & SJC & potentlal \\
\hline 146 & Backhoo Mounted Pulverizer & PAM & 311.1 & 01 & 01 & 04 & 28 & 89 & 89 & SJC & probablo \\
\hline 147 & Bulldozer & PAM & 3.114 & 01 & 02 & 04 & 27 & 89 & 89 & SJC & probabio \\
\hline 147 & Bulldozer & PAM & 3.114 & 01 & 02 & 04 & 28 & 99 & 89 & SJIC & probable \\
\hline 147 & Bulldozer & PAM & 3114 & 01 & 03 & 04 & 27 & 99 & 89 & SJc & probablo \\
\hline 147 & Bulldozer & PAM & 3114 & 01 & 03 & 04 & 28 & 89 & 99 & SJC & probablo \\
\hline 148 & Cablo Suspended Exeavator Attachments & PAM & 3.11 .5 & 01 & 02 & 04 & 27 & 89 & 89 & SJC & probablo \\
\hline 148 & Cablo Suspended Excavator Attachments & PAM & 311.5 & 01 & 02 & 04 & 28 & 89 & 89 & SJC & probablo \\
\hline 148 & Cablo Suspendod Excavator Attachmenls & PAM & 3115 & 01 & 03 & 04 & 28 & 89 & 89 & SJC & probablo \\
\hline 149 & Jackhammer & PAM & 3.12 .1 & 01 & 01 & 04 & 28 & 89 & 89 & SJC & polontial \\
\hline 150 & Grapplo & PAM & 3135 & 01 & 02 & 04 & 27 & 89 & 99 & sJC & prelorred \\
\hline 150 & Grapplo & PAM & 3.135 & 01 & 02 & 04 & 28 & 99 & 99 & s.JC & proforred \\
\hline 150 & Grapplo & PAM & 3135 & 01 & 03 & 04 & 27 & 99 & 89 & SJC & preferted \\
\hline 150 & Grappla & PAM & 3135 & 01 & 03 & 04 & 28 & 99 & 99 & SJC & proforred \\
\hline 151 & Inorganic based encapsulation & PAM & 3141 & 02 & 05 & 08 & 37 & 99 & 99 & MAM & probablo \\
\hline 151 & Inorganic besed encapsulation & PAM & 3.141 & 02 & 05 & $\mathbf{O B}$ & 38 & 99 & 89 & MAM & probablo \\
\hline 151 & Inorganic based encapsulation & PAM & 3.14 .1 & 02 & 05 & 08 & 39 & 99 & 99 & MAM & probablo \\
\hline 151 & Inorganic besed encapsulation & PAM & 3.141 & 02 & 05 & 08 & 10 & 99 & 99 & MAM & probablo \\
\hline 151 & Inorganic based oncapsulation & PAM & 314.9 & 02 & 05 & $O B$ & 41 & 99 & 99 & MAM & probablo \\
\hline 151 & Inorganic based encapsulation & PAM & 3.14 .1 & 02 & 05 & 08 & 42 & 99 & 99 & MAM & potontial \\
\hline 151 & Inorganic based encapsulation & PAM & 3.141 & 02 & $\infty$ & 08 & 39 & 99 & 99 & MAM & probable \\
\hline $15 i$ & Inorganic basod encapsulation & PAM & 3.14 .1 & 02 & 07 & 08 & 39 & 99 & 99 & MAM & potential \\
\hline 152 & Macroencapsulation & PAM & 3.142 & 02 & 05 & 08 & 43 & 99 & 99 & MAM & potential \\
\hline
\end{tabular}




\begin{tabular}{|c|c|c|c|c|c|c|c|c|c|c|c|}
\hline Tech ID & Technology This & Data Source & $\begin{array}{l}\text { Data Sourco } \\
\text { Identifier }\end{array}$ & $\begin{array}{c}(00) \\
\text { Decommissioning } \\
\text { Categorlos }\end{array}$ & $\begin{array}{l}\text { (01) Material } \\
\text { Types }\end{array}$ & $\begin{array}{l}\text { (02) Procoss } \\
\text { Types }\end{array}$ & $\begin{array}{c}\text { (03) Process } \\
\text { Sub-Typos }\end{array}$ & $\begin{array}{l}\text { (04) Condition } \\
\text { Calegories }\end{array}$ & $\begin{array}{l}\text { (05) Condllion } \\
\text { Sub. } \\
\text { Categories }\end{array}$ & $\begin{array}{l}\text { Basic Dala } \\
\text { Entered By }\end{array}$ & Comment \\
\hline 153 & Organic based encapsulation & PAM & 3143 & 02 & 05 & 08 & 37 & 99 & 99 & MAM & potontial \\
\hline 153 & Organic based encapsulation & PAM & 3143 & 02 & 05 & 08 & 38 & 99 & 99 & MAM & polential \\
\hline 153 & Organic based encapsulation & PAM & 3143 & 02 & 05 & o8 & 39 & 99 & 99 & MAM & potential \\
\hline 153 & Organic based encapsulation & PAM & 3143 & 02 & 05 & 08 & 40 & 99 & 99 & MAM & potental \\
\hline 153 & Organlc based encapsulation & PAM & 3143 & 02 & 05 & 08 & 41 & 99 & 99 & MAM & potentlal \\
\hline 153 & Organic based encapsulation & PAM & 3143 & 02 & DB & OB & 39 & 99 & 99 & MAM & potentlal \\
\hline 153 & Organic based encepsulation & PAM & 3143 & 02 & 07 & 08 & 39 & 99 & 99 & MAM & potential \\
\hline 154 & RetorvAmalgamation & PAM & 3144 & 02 & 05 & OQ & 38 & 99 & 99 & MAM & potentla! \\
\hline 154 & RotorvAmalgamation & PAM & 3144 & 02 & 05 & OB & 41 & 99 & 99 & MAM & potental \\
\hline 155 & Erickmaklng & PAM & 3151 & 02 & 05 & 08 & 38 & 99 & 99 & MAM & potonlial \\
\hline 155 & Brickmaking & PAM & 3151 & 02 & 05 & 08 & 39 & 99 & 99 & MAM & potential \\
\hline 155 & Brickmaking & PAM & 3151 & 02 & 05 & 08 & 41 & 89 & 99 & MAM & potentlal \\
\hline 155 & Brickmaking & PAM & 3151 & 02 & $\infty$ & $0 B$ & 39 & 99 & 99 & MAM & potential \\
\hline 158 & Calcination & PAM & 3152 & 02 & 05 & OB & 37 & 99 & 99 & MAM & potentlal \\
\hline 156 & Calcination & PAM & 3152 & 02 & 05 & 08 & 39 & 99 & 99 & MAM & potential \\
\hline 158 & Calcination & PAM & 3152 & 02 & 05 & 08 & 40 & 99 & 99 & MAM & polential \\
\hline 158 & Calcination & PAM & 3152 & 02 & 08 & 08 & 39 & 99 & 99 & MAM & potontial \\
\hline 158 & Calcination & PAM & 3152 & 02 & 06 & 08 & 39 & 99 & 99 & MAM & potential \\
\hline 157 & Open Buming'Open Delonation & PAM & 3153 & 02 & 05 & 08 & 38 & $\boldsymbol{9 9}$ & 99 & MAM & probablo \\
\hline 157 & Open Burning/Open Detonation & PAM & 3153 & 02 & 05 & 08 & 41 & 99 & 99 & MAM & probable \\
\hline 157 & Open Burning/Open Detonation & PAM & 3153 & 02 & 05 & OB & 42 & 99 & 99 & MAM & potential \\
\hline 158 & $\begin{array}{l}\text { Drying/Dewatenng } \\
\text { D }\end{array}$ & PAM & 3154 & 02 & 05 & 08 & 37 & 99 & 99 & MAM & probablo \\
\hline 158 & Dying/Dewatering & PAM & 3154 & 02 & 05 & 08 & 30 & 99 & 99 & MAM & probablo \\
\hline 158 & Dying/Dewatering & PAM & 3154 & 02 & 05 & 08 & 39 & 99 & 99 & MAM & probablo \\
\hline 158 & Dring/Dewatering & PAM & 3154 & 02 & 05 & 08 & 40 & 99 & 99 & MAM & probablo \\
\hline 158 & Dying/Dowatering & PAM & 3154 & 02 & 05 & 08 & 41 & 99 & 99 & MAM & probable \\
\hline 158 & Drying/Dewatening & PAM & 3154 & 02 & 06 & 08 & 39 & 89 & 99 & MAM & probable \\
\hline 159 & High Temperaluie Thermal Desorption & PAM & 3155 & 02 & 05 & 08 & 37 & 99 & 99 & MAM & polential \\
\hline 159 & High Temperalure Thermal Desorption & PAM & 3155 & 02 & 05 & 08 & 38 & 99 & 99 & MAM & potental \\
\hline 159 & High Temperature Thermal Desorption & PAM & 3155 & 02 & 05 & 08 & 40 & 99 & 99 & MAM & polents: \\
\hline 159 & High Temperature Thermal Desorption & PAM & 3155 & 02 & 05 & $0 B$ & 41 & 99 & 99 & MAM & potential \\
\hline 180 & Incineration & PAM & 3156 & 02 & 05 & 08 & 37 & 99 & 99 & MAM & polential \\
\hline 180 & Incineration & PAM & 3156 & 02 & 05 & 08 & 38 & 99 & 99 & MAM & potentiat \\
\hline 160 & Incineration & PAM & 3156 & 02 & 05 & 08 & 40 & 89 & 89 & MAM & potental \\
\hline 160 & Inaneration & PAM & 3156 & 02 & 05 & 08 & 41 & 99 & 99 & MAM & polentiat \\
\hline 181 & Low temperalure thermat desorption & PAM & 3157 & 02 & 05 & 08 & 37 & 99 & 89 & MAM & probablo \\
\hline 161 & Low temperature thermal desorption & PAM & 3157 & 02 & 05 & 08 & 38 & 99 & 99 & MAM & potential \\
\hline 161 & Low lemperature thermal desorption & PAM & 315.7 & 02 & 05 & 08 & 40 & 99 & 89 & MAM & probablo \\
\hline 161 & Low temperalure thermal desorption & PAM & 3157 & 02 & 05 & 08 & 41 & 89 & 99 & MAM & polential \\
\hline 162 & $\begin{array}{l}\text { Pyrolysis } \\
\text { Pas }\end{array}$ & PAM & 3159 & 02 & 05 & 08 & 40 & 99 & 99 & MAM & potentual \\
\hline 163 & Steam reforming & PAM & 315.10 & 02 & 05 & OB & 37 & 89 & 88 & MAM & polenvial \\
\hline 163 & Steam reloming & PAM & 315.10 & 02 & 05 & 08 & 40 & 99 & 99 & MAM & polential \\
\hline 164 & Vitrification & PAM & 31511 & 02 & 05 & 08 & 37 & 99 & 89 & MAM & potentisi \\
\hline 164 & Viturication & PAM & 31511 & 02 & 05 & OB & 38 & 99 & 99 & MAM & potontial \\
\hline 164 & Vilfification & PAM & 31511 & 02 & 05 & 08 & 39 & 99 & 99 & MAM & potential \\
\hline 164 & Vitnfication & PAM & 31511 & 02 & 05 & 08 & 40 & 99 & 99 & MAM & potental \\
\hline 164 & Vitrification & PAM & 31511 & 02 & 05 & OB & 41 & 99 & 99 & MAM & potential \\
\hline 164 & Vitrification & PAM & 315.11 & 02 & 06 & $0 B$ & 39 & 99 & 99 & MAM & polential \\
\hline 165 & Advanced adsorbents & PAM & 3162 & 02 & 07 & 08 & 39 & 99 & 99 & MAM & potential \\
\hline 166 & Chemical Reduction/Oxidation & PAM & 3.168 & 02 & 05 & 08 & 38 & 99 & 99 & MAM & probablo \\
\hline 186 & Chemical Reduction Oxidation & PAM & 3188 & 02 & 05 & 08 & 38 & 99 & 99 & MAM & potential \\
\hline 166 & Chemical Reduction/Oxidation & PAM & 3168 & 02 & 05 & 08 & 38 & 99 & 99 & MAM & polential \\
\hline 166 & Chemical Reduction Oxidation & PAM & 3168 & 02 & 05 & 08 & 38 & 99 & 99 & MAM & probablo \\
\hline 168 & Chemical Reduction Oxidation & PAM & 3168 & 02 & 05 & 08 & 38 & 99 & 99 & MAM & potential \\
\hline 166 & Chemical Reduetion Oxidation & PAM & 3168 & 02 & 05 & 08 & 38 & 99 & 99 & MAM & polential \\
\hline 166 & Chemical Reduction Oxidation & PAM & 3168 & 02 & 05 & 08 & 41 & 99 & 99 & MAM & probablo \\
\hline 168 & Chemieal Reduction Oxidation & PAM & 3168 & 02 & 05 & 08 & 41 & 99 & 99 & MAM & potential \\
\hline 166 & Chemical Reductionvoxidation & PAM & 3.168 & 02 & 05 & 08 & $\$ 1$ & 99 & 99 & MAM & potential \\
\hline 166 & Chemical Reduction Oxidation & PAM & 3188 & 02 & 05 & 08 & 21 & 99 & 99 & MAM & probable \\
\hline 166 & Chemicat Reduction Oxidation & PAM & 3.168 & 02 & 05 & 08 & 41 & 99 & 99 & MAM & potential \\
\hline
\end{tabular}




\begin{tabular}{|c|c|c|c|c|c|c|c|c|c|c|c|}
\hline Tech 10 & Technology Titlo & Dats Source & $\begin{array}{l}\text { Dattu Source } \\
\text { tdentiner }\end{array}$ & $\begin{array}{c}(00) \\
\text { Decommissioning } \\
\text { Calegories }\end{array}$ & $\begin{array}{l}\text { (01) Material } \\
\text { Types }\end{array}$ & $\begin{array}{l}\text { (02) Process } \\
\text { Types }\end{array}$ & $\begin{array}{l}\text { (03) Process } \\
\text { Sub-Types }\end{array}$ & $\begin{array}{l}\text { (o4) Condition } \\
\text { Categories }\end{array}$ & $\begin{array}{l}\text { (05) Condition } \\
\text { Sub- } \\
\text { Categories }\end{array}$ & $\begin{array}{l}\text { Basic Data } \\
\text { Entered By }\end{array}$ & Comment \\
\hline 166 & Chemical Reduction/Oxidation & PAM & 3.168 & 02 & 05 & 08 & 41 & 99 & 99 & MAM & potential \\
\hline 187 & CO2 Blasting & PAM & 3.169 & 02 & 05 & 08 & 43 & 99 & 99 & MAM & probable \\
\hline 187 & CO2 Blasting & PAM & 3.189 & 02 & 05 & 08 & 99 & 99 & 99 & MAM & probablo \\
\hline 168 & Dehalogenation & PAM & 3.18 .13 & 02 & 05 & 08 & 37 & 99 & 99 & MAM & potential \\
\hline 168 & Dehalogenation & PAM & 3.18 .13 & 02 & 05 & 08 & 40 & 99 & 99 & MAM & polential \\
\hline 169 & Electrochemical & PAM & 316.15 & 02 & 05 & 08 & 37 & 99 & 99 & MAM & potential \\
\hline 169 & Electrochemical & PAM & 3.16 .15 & 02 & 05 & 08 & 38 & 99 & 99 & MAM & polential \\
\hline 189 & Electrochemical & PAM & 3.16 .15 & 02 & 05 & 08 & 40 & 99 & 99 & MAM & polential \\
\hline 169 & - Electrochernical & PAM & 3.16 .15 & 02 & 05 & 08 & 41 & 99 & 99 & MAM & potential \\
\hline 169 & Electrochemical & PAM & 3.18 .15 & 02 & 05 & OB & 43 & 99 & 99 & MAM & $\begin{array}{l}\text { potential } \\
\text { pol }\end{array}$ \\
\hline 169 & Electrochemical & PAM & 3.16 .15 & 02 & 05 & 08 & 99 & 99 & 99 & MAM & potential \\
\hline 170 & Ion Exchango & PAM & 3.16 .21 & 02 & 07 & 08 & 39 & 99 & 99 & MAM & potential \\
\hline 171 & Mechanical separation & PAM & 31622 & 02 & 05 & 08 & 42 & 99 & 99 & MAM & probablo \\
\hline 171 & Mechanical separation & PAM & 3.16 .22 & 02 & 05 & 08 & 99 & 99 & 89 & MAM & potential \\
\hline 172 & Roverse Osmosis & PAM & 3.18 .23 & 02 & 07 & 08 & 39 & 99 & 99 & MAM & polential \\
\hline & Procipitation & PAM & 3.1624 & 02 & 07 & 08 & 39 & 99 & 99 & MAM & probable \\
\hline 174 & $\begin{array}{l}\text { Fittration } \\
\text { lat }\end{array}$ & PAM & 31625 & 02 & 07 & 08 & 39 & 99 & 99 & MAM & probablo \\
\hline 175 & Solar Evaporation & PAM & 31627 & 02 & 07 & 08 & 39 & 99 & 99 & MAM & $\begin{array}{l}\text { probablo } \\
\text { probalo }\end{array}$ \\
\hline 178 & Volumo Reduetion/Compaction & PAM & 31631 & 02 & 05 & $0 B$ & 42 & 99 & 99 & MAM & probablo \\
\hline 178 & Volume Reduction/Compaction & PAM & 3.16 .31 & 02 & 05 & 08 & 99 & 99 & 99 & MAM & probablo \\
\hline 177 & Landfrls (RCRA, Radioactivo, TSCA, Mixed & PAM & 3173 & 02 & 05 & 08 & 37 & 99 & 99 & MAM & potential \\
\hline 177 & Landfills (RCRA, Radioactivo, TSCA, Mixed & PAM & 3.173 & 02 & 05 & 08 & 38 & 99 & 99 & MAM & potential \\
\hline 177 & Landrils (RCRA. Radioactivo, TSCA. Mixed & PAM & 317.3 & 02 & 05 & 08 & 39 & 99 & 99 & MAM & potential \\
\hline 178 & 3-Trash Pump-Wacker PT 3A & Phoenix & & 02 & 07 & 08 & 99 & 99 & 99 & SJC & \\
\hline 179 & 40K Floor Machine & Phoenix & & 01 & 01 & 02 & 07 & 99 & 99 & suc & \\
\hline 179 & 40K Floor Machine & Phoenix & & 01 & 02 & 02 & 11 & 05 & 99 & sJc & \\
\hline 180 & Abrasive Blaster-MP 1 & Phoenix & & 01 & 01 & 02 & 07 & 01 & 03 & s.c & \\
\hline 180 & Abrasive Blaster- MP 1 & Phoenix & & 01 & 01 & 02 & 08 & 01 & 03 & SJC & \\
\hline 180 & Abrasive Blaster- MP 1 & Phoenix & & 01 & 01 & 02 & 08 & 02 & 03 & suc & \\
\hline 180 & Abrasive Blaster-MP 1 & Phoenix & & 01 & 02 & 02 & 09 & 99 & 99 & SJC & \\
\hline 160 & Abrasive Blaster-MP 1 & Phoenix & & 01 & 02 & 02 & 10 & 03 & 99 & SJC & \\
\hline 180 & Abrasive Blaster- MP 1 & Phoenix & & 01 & 02 & 02 & 10 & 04 & 99 & suc & \\
\hline 180 & Abrasive Blaster- MP 1 & Phoenix & & 01 & 02 & 02 & 11 & 05 & 02 & SJC & \\
\hline 180 & Abrasive Blaster-MP 1 & Phoenix & & 01 & 02 & 02 & 11 & 06 & 02 & SJC & \\
\hline 181 & Abrasive Blaster-MP 3 & Phoenix & & 01 & 01 & 02 & 07 & 01 & 03 & SJC & \\
\hline 181 & Abrasive Blaster-MP 3 & Phoenix & & 01 & 01 & 02 & 08 & 01 & 03 & SJC & \\
\hline 181 & Abrasive Blaster-MP 3 & Phoenix & & 01 & 01 & 02 & 08 & 02 & 03 & SJC & \\
\hline 181 & Abrasive Blaster-MP 3 & Phoonix & & 01 & 02 & 02 & 09 & 89 & 99 & SJC & \\
\hline 181 & Abrasive Blaster- MP 3 & Phoenix & & 01 & 02 & 02 & 10 & 03 & 99 & SJC & \\
\hline 181 & Abrasive Blaster. MP 3 & Phoenix & & 01 & 02 & 02 & 10 & 04 & 99 & SJC & \\
\hline 101 & Abrasive Blaster. MP 3 & Phoenix & & 01 & 02 & 02 & 11 & 05 & 02 & SJC & \\
\hline 181 & Abrasive Blaster. MP 3 & Phoenix & & 01 & 02 & 02 & 11 & $\infty$ & 02 & suc & \\
\hline 182 & Abrasive Blaster. MPC & Phoenix & & 01 & 01 & 02 & 07 & or & 03 & Suc & \\
\hline 182 & Abrasive Elaster-MPC & Phoenix & & 01 & 01 & 02 & 08 & 01 & 03 & SNC & \\
\hline 182 & Abrasive Elaster-MPC & Phoenix & & 01 & 01 & 02 & 00 & 02 & 03 & suc & \\
\hline 182 & Abrasive Blaster- MPC & Phoenix & & 01 & 02 & 02 & 09 & 99 & 99 & SJC & \\
\hline 182 & Abrasive Blaster-MPC & Phoenix & & 01 & 02 & 02 & 10 & 03 & 99 & sjc & \\
\hline 182 & Abrasive Blaster-MPC & Phoenix & & 01 & 02 & 02 & 10 & 04 & 99 & Suc & \\
\hline 182 & Abrasive Blaster-MPC & Phoenix & & 01 & 02 & 02 & 11 & 05 & 02 & SUC & \\
\hline 182 & Abrasive Blaster-MPC & Phoenlx & & 01 & 02 & 02 & 11 & 06 & 02 & SJC & \\
\hline 183 & Abrasive Blaster-MPC (1-3) & Phoenix & & 01 & 01 & 02 & 07 & 01 & 03 & ssc & \\
\hline 183 & Abrasive Blaster-MPC (1-3) & Phoenix & & 01 & 01 & 02 & ob & 01 & 03 & SIC & \\
\hline 183 & Abrasive Blaster-MPC (1.3) & Phoenix & & 01 & 01 & 02 & 08 & 02 & 03 & sJC & \\
\hline 183 & Abrasive Blaster- MPC (1-3) & Phoenix & & 01 & 02 & 02 & 09 & 99 & 89 & suc & \\
\hline 183 & Abrasive Blaster-MPC (1.3) & Phoenix & & 01 & 02 & 02 & 10 & 03 & 99 & suc & \\
\hline 183 & Abrasive Blaster-MPC (1.3) & Phoenix & & 01 & 02 & 02 & 10 & 04 & 99 & SJe & \\
\hline 183 & Abrasive Blaster- MPC (1-3) & Phoenix & & 01 & 02 & 02 & 11 & 05 & 02 & suc & \\
\hline 183 & Abrasive Blaster. MPC (1.3) & Phoenix & & 01 & 02 & 02 & 11 & $O B$ & 02 & sic & \\
\hline 103 & Abra sive Blaster. MPC (1-3) & Phoenix & & 01 & 02 & 02 & 12 & 07 & 99 & suc & \\
\hline 183 & Abrastve Blaster-MPC (1-3) & Phoenix & & 01 & 02 & 02 & 12 & 08 & 89 & SIC & \\
\hline
\end{tabular}




\begin{tabular}{|c|c|c|c|c|c|c|c|c|c|c|}
\hline Tech 10 & Technology Title & Data Sourco & $\begin{array}{l}\text { Data Source } \\
\text { Identlifer }\end{array}$ & $\begin{array}{c}\{00\rangle \\
\text { Cocommissionino } \\
\text { Calegorlos }\end{array}$ & $\begin{array}{c}\text { (01) Matorlal } \\
\text { Types }\end{array}$ & $\begin{array}{c}\text { (02) Process } \\
\text { Typos }\end{array}$ & $\begin{array}{l}\text { (03) Process } \\
\text { Sub.Types }\end{array}$ & $\begin{array}{l}\text { (04) Condition } \\
\text { Cattogorites }\end{array}$ & $\begin{array}{l}\text { (05) Condition } \\
\text { Sub. } \\
\text { Categories }\end{array}$ & $\begin{array}{l}\text { Basle Data } \\
\text { Entered By }\end{array}$ \\
\hline 183 & Abrasivo Blaster-MPC (1-3) & Phoenix & & 01 & 02 & 02 & 12 & 99 & 99 & ssc \\
\hline 184 & Aerosol Generator & Phoenix & & 00 & $\infty$ & $\infty$ & 36 & 99 & 99 & SNC \\
\hline 185 & Air Blast Cleaning System & Phoenix & & 01 & 01 & 02 & 07 & 01 & 03 & S.SC \\
\hline 185 & Air Blast Cloaning System & Phoenix & & 01 & 01 & 02 & 07 & 02 & 03 & s.c \\
\hline 185 & Air Blast Cleanino System & Phoenix & & 01 & 01 & 02 & OB & 01 & 03 & ssc \\
\hline 185 & Air Blast Cloaning System & Phoenix & & 01 & 01 & 02 & 08 & 02 & 03 & sJc \\
\hline 185 & Air Blast Cleaning System & Phoenix & & 01 & 02 & 02 & 09 & 99 & 99 & suc \\
\hline 185 & Air Blast Cloaning Systom & Phoenlx & & 01 & 02 & 02 & 10 & 03 & 89 & suc \\
\hline 185 & - Air Blast Cleaning System & Phoenix & & 01 & 02 & 02 & 11 & 05 & 02 & SJC \\
\hline 186 & Alr Pak AP. 2000 & Phoenix & & 00 & 00 & 00 & 38 & 99 & 99 & SJC \\
\hline 187 & Air Pak AP.2000.CH & Phoenix & & $\infty$ & $\infty$ & $\infty$ & 36 & 99 & 99 & s.se \\
\hline 980 & Air Pak AP. 4000 & Phoenix & & 00 & $\infty$ & $\infty$ & 30 & 99 & 99 & Suc \\
\hline 189 & Air Pak AP.4000.CH & Phoenix & & $\infty$ & $\infty$ & 08 & 36 & 99 & 89 & SIC \\
\hline 190 & Air Sampler- BS & Phoonlx & & 00 & $\infty$ & $\infty$ & 34 & 99 & 89 & Suc \\
\hline 191 & Air Sampler- LV.1 & Phoenix & & 00 & 00 & 06 & 34 & 99 & 89 & suc \\
\hline 192 & Air Sampler- LV.2 & Phoenix & & 00 & $\infty$ & 06 & 34 & 99 & 99 & SJE \\
\hline 193 & Air Sempler. RAS-1 & Phoonix & & 00 & 00 & $\infty$ & 34 & 99 & 99 & SJC \\
\hline 194 & Air Samplor-TFIA-2 & Phoenix & & $\infty$ & $\infty$ & 00 & 34 & 99 & 89 & SIC \\
\hline 195 & Air Samplor.TFiA-3 & Phoonix & & 00 & $\infty$ & $\infty$ & 34 & 99 & 99 & suc \\
\hline 198 & Air Sampler-JFIA-4 & Phoenix & & 00 & $\infty$ & $\infty$ & 34 & 99 & 99 & SJC \\
\hline 197 & All Weather Shelters $(12 \times 20 \times 6)$ & Phoenix & & $\infty$ & $\infty$ & 06 & 38 & 99 & 99 & suc \\
\hline 198 & All Woather Shelters $(24 \times 20 \times 8)$ & Phoonix & & 00 & $\infty$ & $\infty$ & 38 & 99 & 99 & SIC \\
\hline 199 & Alpha Air Monitor. Alpha.6 & Phoenix & & 00 & 00 & 06 & 34 & 99 & 99 & SIC \\
\hline 200 & Alpha Sentillation Probe- AC.3 & Phoenix & & 00 & $\infty$ & 06 & 34 & 99 & 99 & SJc \\
\hline 201 & Allemating Saw & Phoenix & & 01 & 02 & 03 & 17 & 10 & 99 & S.JC \\
\hline 201 & Allemating Saw & Phoenix & & 01 & 02 & 03 & 10 & 10 & 99 & SNC \\
\hline 202 & AMS Carbon Soll Auger. Sampling Equipment & Phoenix & & 00 & $\infty$ & 89 & 99 & 99 & 99 & MAM \\
\hline 203 & Analog Smant Portable- ASP.1 & Phoenix & & 01 & 00 & $\infty$ & 34 & 99 & 99 & MAM \\
\hline 203 & Analog Sman Ponlabio. ASP.1 & Phoenix & & 01 & 01 & 01 & 01 & 99 & 99 & MAM \\
\hline 203 & Analog Smant Portable. ASP.1 & Phoenix & & 01 & 02 & 01 & 01 & 99 & 99 & MAM \\
\hline 203 & Analog Smant Portable. ASP.1 & Phoenix & & 01 & 02 & 01 & 02 & 99 & 99 & MAM \\
\hline 203 & Analog Smant Portable-ASP.1 & Phoenix & & 01 & 03 & 01 & 01 & 99 & 99 & MAM \\
\hline 203 & Analog Smart Portable. ASP.1 & Phoenix & & 01 & 04 & 01 & 01 & 99 & 99 & MAM \\
\hline 203 & Analog Smart Portable-ASP. 1 & Phoenix & & 02 & $\infty$ & $\infty$ & 34 & 99 & 99 & MAM \\
\hline 203 & Analog Smart Portablo-ASP.1 & Phoenix & & 02 & 05 & 01 & of & 99 & 99 & MAM \\
\hline 204 & Asbestos Pipe-Insulation Syslem & Phoenix & & 01 & 04 & 02 & 99 & 99 & 99 & suc \\
\hline 205 & Asphalt, Concrele \& Metal Air Hammer Bits & Phoenix & & 01 & 00 & 04 & 99 & 99 & 99 & suc \\
\hline 205 & Asphalt, Concrele \& Metal Air Hammer Bils & Phoenix & & 01 & 01 & 04 & 99 & 99 & 99 & Suc \\
\hline 205 & Asphall, Concrele \& Melal Air Hammer Bits & Phoenix & & 01 & 02 & 04 & 99 & 89 & 99 & SJC \\
\hline 206 & Bandsaw-AC-7 & Phoenix & & 01 & 02 & 03 & 16 & 10 & 99 & sJc \\
\hline 206 & Bandsaw-AC-7 & Phoenix & & 01 & 02 & 03 & 18 & 10 & 89 & sJc \\
\hline 207 & Bandsaw-8-25-1 & Phoenix & & 01 & 02 & 03 & 17 & 10 & 99 & s.c \\
\hline 208 & Bandsaw- B-25-2 & Phoenix & & 01 & 02 & 03 & 17 & 10 & 99 & SJC \\
\hline 209 & Bandsaw- B.25.2C & Phoenix & & 01 & 02 & 03 & 17 & 10 & 99 & sJc \\
\hline 210 & Bandsaw- 8-25-3 & Phoenix & & 01 & 02 & 03 & 17 & to & 99 & suc \\
\hline 211 & Bandsaw- B-25-3C & Phoenix & & 01 & 02 & 03 & 17 & 10 & 99 & SJC \\
\hline 212 & Bandsaw- B-25-4 & Phoenix & & 01 & 02 & 03 & 17 & to & 99 & SJC \\
\hline 213 & Bandsaw-F-16-1 & Phoenix & & 01 & 02 & 03 & 17 & 10 & 99 & SJC \\
\hline 213 & Bandsaw. F-18-1 & Phoenix & & 01 & 02 & 03 & 18 & 10 & 99 & suc \\
\hline 214 & Bandsaw-F-16-2 & Phoenix & & 01 & 02 & 03 & 17 & 10 & 99 & Suc \\
\hline 214 & Bandsaw-F-16-2 & Phoenlx & & 01 & 02 & 03 & 18 & 10 & 99 & Suc \\
\hline 215 & Bandsaw. F. 16-2A & Phoenix & & 01 & 02 & 03 & 17 & 10 & 99 & SUC \\
\hline 215 & Bandsaw-F-10-2A & Phoenix & & 01 & 02 & 03 & 18 & 10 & 99 & SJC \\
\hline 216 & Bandsaw. F.16-2U & Phoenix & & 01 & 02 & 03 & 17 & 10 & 99 & SJC \\
\hline 217 & Bandsaw- $L=10$ & Phoenix & & 01 & 02 & 03 & 17 & 10 & 99 & sJc \\
\hline 217 & Bandsaw-L-10 & Phoenix & & 01 & 02 & 03 & 18 & 10 & 99 & S.JC \\
\hline 218 & Bandsow-P.50-3 & Phoenix & & 01 & 02 & 03 & 17 & 10 & 99 & suc \\
\hline 219 & Bandsaw R.2024-3 & Phoenix & & 01 & 02 & 03 & 17 & 10 & 89 & $\mathrm{suc}$ \\
\hline 220 & Bandsaw-vco-2530 & Phoenix & & 01 & 02 & 03 & 17 & 10 & 99 & SJC \\
\hline 221 & Bandsow- vco-2535 & Phoenix & & 01 & 02 & 03 & 17 & 10 & 99 & SJC \\
\hline
\end{tabular}




\begin{tabular}{|c|c|c|c|c|c|c|c|c|c|c|}
\hline Tech 10 & Technology Title & Data Souree & $\begin{array}{l}\text { Data Source } \\
\text { Identifier }\end{array}$ & $\begin{array}{c}(00) \\
\text { Decommissioning } \\
\text { Categories }\end{array}$ & $\begin{array}{l}\text { (01) Material } \\
\text { Types }\end{array}$ & $\begin{array}{l}\text { (02) Process } \\
\text { Types }\end{array}$ & $\begin{array}{l}\text { (03) Process } \\
\text { Sub-Types }\end{array}$ & $\begin{array}{l}\text { (04) Condition } \\
\text { Categories }\end{array}$ & $\begin{array}{l}\text { (05) Condition } \\
\text { Sub. } \\
\text { Cotegories }\end{array}$ & $\begin{array}{l}\text { Basic Data } \\
\text { Entered By }\end{array}$ \\
\hline 222 & Bandsaw-W-10-1 & Phoenix & & 01 & 02 & 03 & 17 & 10 & 99 & suc \\
\hline 222 & Bandsaw-W-10-i & Phoenix & & 01 & 02 & 03 & 18 & 10 & 99 & SJC \\
\hline 223 & Bandsaw-W-10-2 & Phoenix & & 01 & 02 & 03 & 17 & 10 & 99 & ssc \\
\hline 223 & Bandsaw-W: $\$ 0.2$ & Phoenix & & 01 & 02 & 03 & 18 & 10 & 99 & ssc \\
\hline 224 & Bandsaw. W.10-2A Aulomatic & Phoenix & & 01 & 02 & 03 & 17 & 10 & 99 & suc \\
\hline 224 & Bandsaw-W.10-2A Automatic & Phoenix & & 01 & 02 & 03 & 18 & 10 & 99 & SJC \\
\hline 225 & Bandsaw-w-g-1 & Phoenix & & 01 & 02 & 03 & 17 & 10 & 99 & SJC \\
\hline 225 & Bandsaw-W.g-1 & Phoenix & & 09 & 02 & 03 & 18 & 10 & 99 & SJC \\
\hline 226 & Bandsaw-W.9-1A1 & Phoenix & & 01 & 02 & 03 & 17 & 10 & 99 & SIC \\
\hline 226 & Bandsaw. W-g-1AI & Phoenix & & 01 & 02 & 03 & 18 & 10 & 99 & SJC \\
\hline 227 & Bandsaw-W.g-1A3 & Phoenix & & 01 & 02 & 03 & 17 & 10 & 99 & suc \\
\hline 227 & Bandsaw-W-9-1A3 & Phoenix & & 01 & 02 & 03 & 18 & 10 & 99 & ssc \\
\hline 228 & Bandsaw- $\times 6031.2$ & Phoonix & & 01 & 02 & 03 & 17 & 10 & 99 & suc \\
\hline 229 & Bandsaw-S-40-3 & Phoenix & & 01 & 02 & 03 & 17 & 10 & 99 & SJC \\
\hline 230 & Barrel Monitor. BRC Wasto Analyzer & Phoenix & & 02 & 00 & $\infty$ & 34 & 89 & 99 & MAM \\
\hline 230 & Barrel Monitor- BRC Wasto Analyzer & Phoenix & & 02 & $\infty$ & 01 & 01 & 89 & 89 & MAM \\
\hline 231 & Beta Air Monitor-AMS-4 & Phoenix & & 01 & 00 & 08 & 34 & 99 & 99 & MAM \\
\hline 231 & Beta Air Monilor- AMS-4 & Phoenix & & 0 of & 01 & 01 & 01 & 99 & 99 & MAM \\
\hline 232 & & Phoenlx & & 01 & 00 & 08 & 34 & 99 & 99 & MAM \\
\hline 232 & Bicron Micro Rem-Micro Retm & Phoenix & & 01 & 01 & 01 & 01 & 99 & 89 & MAM \\
\hline 232 & Bicron Micro Rem. Micro Rem & Phoenix & & 01 & 02 & 01 & 01 & 99 & 99 & MAM \\
\hline 232 & Bicron Micro Rem-Micro Rem & Phoonix & & 01 & 02 & 01 & 02 & 99 & 99 & MAM \\
\hline 232 & Bieron Micro Rem-Micro Rem & Phoenix & & 01 & 03 & 01 & 01 & 89 & 89 & MAM \\
\hline 232 & Bicron Miero Rem-Micro Rem & Phoenix & & 01 & 04 & 01 & 01 & 89 & 99 & MAM \\
\hline 232 & Bicron Miero Rem-Micro Rem & Phoenix & & 02 & $\infty$ & 08 & 34 & 89 & 99 & MAM \\
\hline 232 & Bicron Miero Rom-Micro Rom & Phoenix & & 02 & 05 & 01 & 01 & 99 & 99 & MAM \\
\hline 233 & Cadet Vaneaxial. Vontilation Unit & Phoenix & & 01 & 00 & $0 B$ & 34 & 99 & 99 & MAM \\
\hline 234 & Camberra Counting Systom- 2400 & Phoenix & & 01 & 00 & $\infty$ & 34 & 89 & 99 & MAM \\
\hline 236 & Canberra Counting System- 2400 & Phoenix & & 01 & 09 & 01 & 01 & 89 & 99 & MAM \\
\hline 234 & Canberra Counting Syslem-2400 & Phoenix & & 01 & 02 & 01 & 01 & 89 & 89 & MAM \\
\hline 234 & Canbera Counting System. 2400 & Phoonlx & & 01 & 02 & 01 & 02 & 99 & 99 & MAM \\
\hline 234 & Canberra Counting System. 2400 & Phoenix & & 01 & 03 & 01 & 01 & 99 & 89 & MAM \\
\hline 234 & Canberra Counting System- 2400 & Phoenix & & 01 & 04 & 01 & 01 & 89 & 99 & MAM \\
\hline 234 & Canberra Counting System: 2400 & Phoenix & & 02 & DO & $\infty$ & 34 & 89 & 9g & MAM \\
\hline 234 & Canberra Counting System- 2400 & Phoenix & & 02 & 05 & 01 & 01 & 99 & 89 & MAM \\
\hline 235 & Contrifugat Wheel Blast Cleaning System & Phoenix & & 01 & 01 & 02 & 07 & 01 & 03 & SJC \\
\hline 235 & Centrifugal Wheol Blast Cleaning System & Phoenix & & 01 & 01 & 02 & 07 & 02 & 03 & SJC \\
\hline 235 & Centrifugal Wheel Blast Cleaning System & Phoenix & & 01 & 02 & 02 & 09 & 89 & 99 & SJC \\
\hline 235 & Centrifugal Wheel Blast Cleaning System & Phoenix & & 01 & 02 & 02 & 10 & 03 & 99 & SJC \\
\hline 235 & Centrifugal Wheel Elast Cleaning System & Phoonix & & 01 & 02 & 02 & 10 & 04 & 99 & sJc \\
\hline 235 & Centrifugal Wheel Blast Cleaning System & Phoenix & & 01 & 02 & 02 & 11 & 05 & 02 & SJC \\
\hline 238 & $\begin{array}{l}\text { Chemlcal decontamination } \\
\text { nate }\end{array}$ & Phoenix & & 01 & 01 & 02 & 89 & 89 & 99 & SJc \\
\hline 236 & Chemical decontamination & Phoenix & & 01 & 02 & 02 & 99 & 89 & 99 & SIC \\
\hline 238 & Chemical decontamination & Phoenix & & 01 & 03 & 02 & 99 & 89 & $\theta \theta$ & SJC \\
\hline 237 & Chemical Decontamination using Chelating & Phoenix & & 01 & 01 & 02 & 07 & 01 & 03 & SJC \\
\hline 237 & Chemical Deconlamination using Chelating & Phoenix & & 01 & 02 & 02 & 10 & 03 & 99 & SJC \\
\hline 238 & CO2 Blasting Equipment. RDS-1000A & Phoenix & & 01 & 01 & 02 & 99 & จ9 & 99 & S.JC \\
\hline 238 & CO2 Blasting Equipment. RDS. $1000 \mathrm{~A}$ & Phoenix & & 01 & 02 & 02 & 99 & 99 & 99 & SJC \\
\hline 239 & CO2 Blasting Equipment-RDS-250 FP & Phoenix & & 01 & 01 & 02 & 99 & 99 & 99 & S.JC \\
\hline 239 & CO2 Blasting Equipment-RDS-250 FP & Phoenix & & 01 & 02 & 02 & 99 & 99 & 89 & SJC \\
\hline 240 & $\mathrm{CO} 2$ Cleaning. Gen III & Phoenix & & 01 & 01 & 02 & 99 & 99 & 89 & SJC \\
\hline 240 & CO2 Cleaning- Gen III & Phoenix & & 01 & 02 & 02 & 89 & 99 & 99 & SJC \\
\hline 241 & Compactor. C6R 6-90-200 & Phoenix & & 02 & 05 & 05 & 33 & 89 & 99 & MAM \\
\hline 242 & Concrete Cutter & Phoenix & & 01 & 01 & 03 & 99 & 89 & 99 & SJC \\
\hline 242 & Concrete Cutter & Phoenix & & $0 t$ & 02 & 03 & 89 & 10 & 99 & SJC \\
\hline 243 & Concrete Saw. MCC408 & Phoenix & & 01 & 01 & 03 & 14 & 99 & 99 & SJC \\
\hline 244 & Conerele Saw-Minicon 2 & Phoenix & & or & 01 & 03 & 14 & 89 & 89 & ssc \\
\hline 245 & Concrete Scabbler & Phoenix & & 01 & 01 & 02 & 07 & 01 & 03 & SJC \\
\hline 245 & Concrete Scabbler & Phoenix & & 01 & 01 & 02 & 07 & 01 & 04 & SJC \\
\hline 245 & Conereto Seabbler & Phoenix & & 01 & 01 & 02 & 07 & 02 & 03 & SJC \\
\hline
\end{tabular}




\begin{tabular}{|c|c|c|c|c|c|c|c|c|c|c|}
\hline Tech 10 & Technotogy Tille & Data Sourco & $\begin{array}{l}\text { Data Sourca } \\
\text { Identliner }\end{array}$ & $\begin{array}{c}(00) \\
\text { Decommlssioning } \\
\text { Categories }\end{array}$ & $\begin{array}{l}\text { (01) Material } \\
\text { Typos }\end{array}$ & $\begin{array}{l}\text { (02) Process } \\
\text { Types }\end{array}$ & $\begin{array}{l}\text { 10J) Procoss } \\
\text { Sub-Typos }\end{array}$ & $\begin{array}{l}\text { (04) Condillion } \\
\text { Calegorlos }\end{array}$ & $\begin{array}{l}\text { (05) Condition } \\
\text { Sub. } \\
\text { Categorios }\end{array}$ & $\begin{array}{l}\text { Basic Date } \\
\text { Entered By }\end{array}$ \\
\hline 245 & Concrete Scabbler & Phoenix & & 01 & 01 & 02 & 07 & 02 & 04 & suc \\
\hline 245 & Concroto Scabbler & Phoenix & & 01 & 02 & 02 & 99 & 99 & 99 & SJC \\
\hline 248 & Custom Abrasivo Watorjat System & Phoenlx & & 01 & 01 & 04 & 99 & 99 & 99 & SJC \\
\hline 248 & Custom Abrasivo Waloriot System & Phoenix & & 01 & 02 & 04 & 99 & 99 & 99 & SJC \\
\hline 248 & Custom Abrasive Wateriet System & Phoonix & & 01 & 03 & 04 & 99 & 99 & 99 & SJC \\
\hline 247 & Cutting Torch-9000 Seres & Phoenix & & 01 & 02 & 03 & 16 & 09 & 99 & sJc \\
\hline 247 & Culting Torch. 9000 Series & Phoenix & & 01 & 02 & 03 & 17 & 09 & 99 & SJC \\
\hline 247 & Cutting Torch. 9000 Series & Phoenix & & 01 & 02 & 03 & 18 & 09 & 99 & SJC \\
\hline 247 & Cutling Torch. 9000 Series & Phoenix & & 01 & 02 & 03 & 19 & 09 & 99 & SIC \\
\hline 248 & Docon High Pressure Unit. KS $10 \times 15^{\prime}$ & Phoenix & & 01 & 01 & 02 & 07 & 01 & 99 & SIC \\
\hline 248 & Decon High Pressure Unll. KS t0' $\times 15^{\prime}$ & Phoenix & & 01 & 01 & 02 & 07 & 02 & 99 & SJC \\
\hline 248 & Decon High Prossure Unil. KS $10^{\prime} \times 15^{\circ}$ & Phoonix & & 01 & 01 & 02 & 08 & 01 & 89 & SJC \\
\hline 248 & Decon High Prossuro Unit. KS $10^{\circ} \times 15^{\circ}$ & Phoenix & & 01 & 01 & 02 & 08 & 02 & 99 & SJC \\
\hline 248 & Decon High Pressure Unit. KS $10^{\circ} \times 15^{\prime}$ & Phoenix & & 01 & 02 & 02 & 09 & 89 & 99 & SJC \\
\hline $24 \theta$ & Decon High Pressure Unil. KS $10^{\prime} \times 15^{\circ}$ & Phoenix & & 01 & 02 & 02 & 10 & 03 & 99 & SJC \\
\hline 248 & Decon High Pressuro Unit-KS $10^{\circ} \times 15^{\circ}$ & Phoonix & & 01 & 02 & 02 & 11 & 89 & 99 & SIC \\
\hline 249 & Decon High Pressure Unit- KS 48 ( 2 rats ) & Phoonix & & 01 & 01 & 02 & 07 & 01 & 99 & SJC \\
\hline 249 & Decon High Pressure Unil- KS 48 ( 2 refs) & Phoenix & & 01 & 01 & 02 & 07 & 02 & 99 & sJc \\
\hline 249 & Docon High Pressuro Unit- KS 48 ( 2 rots ) & Phoenix & & 01 & 01 & 02 & 08 & 01 & 99 & sJC \\
\hline 249 & Decan High Pressure Unit-KS 48 (2 rols) & Phoenix & & 01 & 01 & 02 & 08 & 02 & 99 & SJC \\
\hline 249 & Decon High Pressure Unit-KS 48 ( 2 refs) & Phoenix & & 01 & 02 & 02 & 09 & 99 & 99 & ssc \\
\hline 249 & Docon High Prossure Unit- KS 48 ( 2 rels) & Phoenix & & of & 02 & 02 & 10 & 03 & 99 & SJC \\
\hline 249 & Decon High Pressure Unit- KS 48 ( 2 refs) & Phoenix & & 01 & 02 & 02 & 11 & 99 & 99 & SJC \\
\hline 250 & Decon High Pressure Unt- KS HP 42 & Phoenix & & 01 & 01 & 02 & 07 & 01 & 99 & SJC \\
\hline 250 & Decon High Pressure Unit- KS MP 42 & Phoenix & & 01 & 01 & 02 & 07 & 02 & 99 & sJc \\
\hline 250 & Decon High Pressure Unit- KS HP 42 & Phoonix & & 01 & 01 & 02 & 08 & 01 & 99 & sJc \\
\hline 250 & Decon High Pressuro Unit-KS HP 42 & Phoenix & & 01 & 01 & 02 & 08 & 02 & 99 & SJC \\
\hline 250 & Decon High Pressure Unit. KS HP 42 & Phoonix & & of & 02 & 02 & 09 & 99 & 99 & suc \\
\hline 250 & Decon Migh Pressure Unit- KS HP 42 & Phoonix & & 01 & 02 & 02 & 10 & 03 & 99 & s.jc \\
\hline 250 & Decon Htgh Pressure Unit. KS HP 42 & Phoenix & & 01 & 02 & 02 & 19 & 99 & 99 & sJc \\
\hline 251 & Decon High Pressura Unit. KS HP S' $\times 18^{\prime}$ & Phoenix & . & 01 & 01 & 02 & 07 & 01 & 99 & SJC \\
\hline 251 & Decon High Pressure Unit. KS HP $5 \times 18^{\prime}$ & Phoenix & & 01 & 01 & 02 & 07 & 02 & 99 & SJC \\
\hline 251 & Decon High Pressure Unit. KS HP $5^{\prime} \times 18^{\circ}$ & Phoenix & & 01 & 01 & 02 & 08 & 01 & 89 & S.JC \\
\hline 251 & Decon High Pressuro Unit- KS HP $5 \times 18^{\prime}$ & Phoenix & & 01 & 01 & 02 & 08 & 02 & 99 & sJc \\
\hline 251 & Decon High Pressuro Unit-KS HP $5^{\prime} \times 10^{\circ}$ & Phoenix & & 01 & 02 & 02 & 09 & 99 & 99 & SJC \\
\hline 251 & Decon High Pressuro Unit- KS HP $5 \times 18^{\circ}$ & Phoenix & & 01 & 02 & 02 & 10 & 03 & 99 & SJC \\
\hline 251 & Decon High Pressure Unit- KS HP $5 \times 18^{\prime}$ & Phoenix & & 01 & - 02 & 02 & 11 & 89 & 99 & SJc \\
\hline 252 & Decon High Pressuro Unit-KS48 × 96 & Phoenix & & 01 & 01 & 02 & 07 & 01 & 99 & s.JC \\
\hline 252 & Decon High Pressure Unit- KS $48 \times 98$ & Phoenix & & 01 & 01 & 02 & 07 & 02 & 99 & suc \\
\hline 252 & Decon High Pressure Unit- KS $48 \times 96$ & Phoenix & & 01 & 01 & 02 & ob & 01 & 99 & suc \\
\hline 252 & Decon High Pressure Unit- KS $48 \times 96$ & Phoenix & & 01 & 01 & 02 & 08 & 02 & 89 & SNC \\
\hline 252 & Decon High Pressure Unit-KS48 x 96 & Phoenix & & 01 & 02 & 02 & 09 & 99 & 89 & S.Jc \\
\hline 252 & Decon High Pressure Unit- KS 48 × 98 & Phoenix & & 01 & 02 & 02 & 10 & 03 & 89 & SIC \\
\hline 252 & Decon High Pressure Unit- KS4B $\times 98$ & Phoenix & & 01 & 02 & 02 & 11 & 99 & 99 & SJC \\
\hline 254 & Demolition Hammer- Wacker EH 23 & Phoenix & . & 01 & 01 & 03 & 14 & 99 & 99 & SIC \\
\hline 255 & Dernolition Hammer. Wacker EHB 10/1 10 & Phoenix & & 01 & 01 & 03 & 14 & 99 & 89 & sJC \\
\hline 256 & Demoltion Hammer-Wacker EHB 7/S & Phoenix & & 01 & 01 & 03 & 14 & 99 & 99 & SJC \\
\hline 257 & Dry lce Blast Unit- $400 \mathrm{~A}, 4008$ & Phoenix & & 01 & 01 & 02 & 99 & 99 & 89 & SJC \\
\hline 257 & Dry lco Blast Unit $400 \mathrm{~A}, 400 \mathrm{~B}$ & Phoenix & . & 01 & 02 & 02 & 99 & 99 & 99 & suc \\
\hline 258 & Dry Ico Elast Unit-Accelerrator 1350-3 & Phoenix & & 01 & 01 & 02 & 99 & 99 & 99 & SNC \\
\hline 258 & Dry lco Blast Unit-Accelerator 1350-3 & Phoenix & & 01 & 02 & 02 & 99 & 99 & 99 & SJC \\
\hline 259 & Dry Wasto Hydraulic Compactor - Slock & Phoenix & & 02 & 05 & 05 & 33 & 99 & 99 & MAM \\
\hline 260 & ELECTROSORB ${ }^{\circ} \mathrm{C}^{*}$ & Phoenix & & 01 & 02 & 02 & 99 & 99 & 89 & SAM \\
\hline 281 & Floor Contamination Montor (Floor Moniton) & Phoenix & & 03 & 00 & 99 & 89 & 99 & 99 & MAM \\
\hline 262 & Fork Lin & Phoenix & & 01 & 00 & 04 & 99 & 89 & 99 & suc \\
\hline 263 & Gas Flow Proportional Probe- HP.100A & Phoenix & & 01 & 00 & $\mathbf{\infty}$ & 34 & 99 & 99 & MAM \\
\hline 264 & Gas Flow Proportional Probo-MP-100B & Phoenix & & 01 & $\infty$ & $\infty$ & 34 & 89 & 99 & MAM \\
\hline 265 & $\begin{array}{l}\text { Gas Phase Decontamination Procoss } \\
\text { Demonstration }\end{array}$ & Phoenix & & 01 & 00 & 02 & 89 & 99 & 99 & SUC \\
\hline 268 & Gel Decontaminatoon & Phoenix & & 01 & 02 & 02 & 99 & 89 & 99 & sJc \\
\hline
\end{tabular}




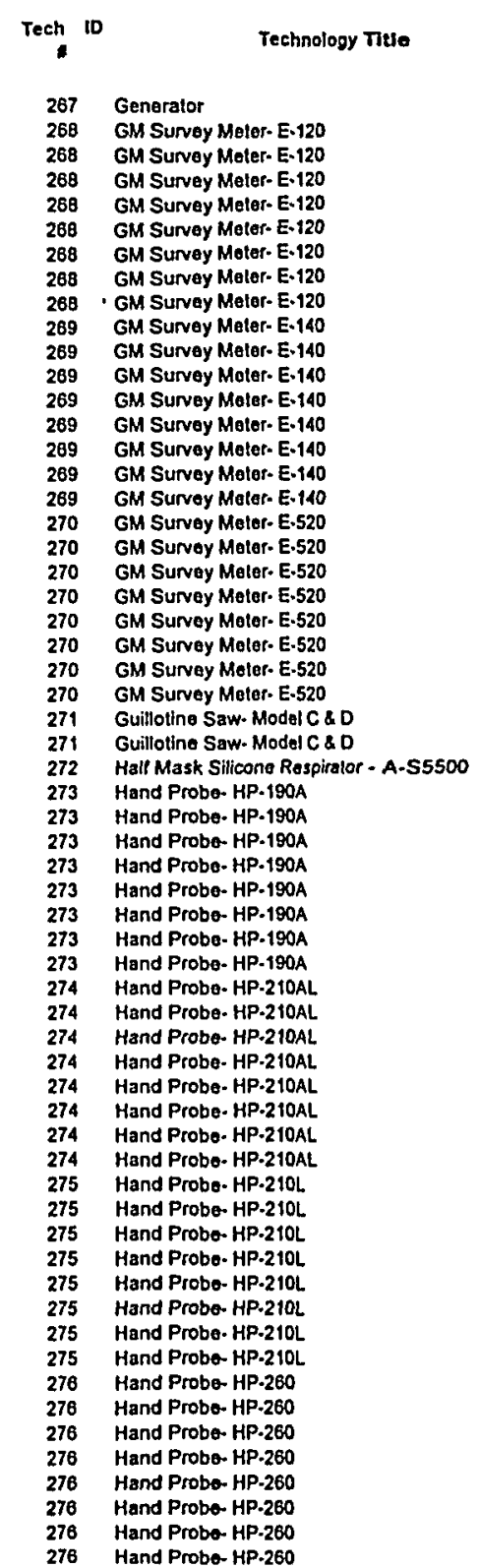

\begin{tabular}{|c|c|c|c|c|c|c|c|c|}
\hline Dats Saurce & $\begin{array}{l}\text { Data Souree } \\
\text { Identifiner }\end{array}$ & $\begin{array}{c}(00) \\
\text { Decommissioning } \\
\text { Categorles }\end{array}$ & $\begin{array}{l}\text { (01) Material } \\
\text { Types }\end{array}$ & $\begin{array}{l}\text { (02) Process } \\
\text { Types }\end{array}$ & $\begin{array}{l}\text { (03) Process } \\
\text { Sub-Types }\end{array}$ & $\begin{array}{l}\text { (O). Condition } \\
\text { Categories }\end{array}$ & $\begin{array}{l}\text { (05) Condition } \\
\text { Sub. } \\
\text { Categories }\end{array}$ & $\begin{array}{l}\text { 8asic Data } \\
\text { Entered By }\end{array}$ \\
\hline Phoenix & & 01 & 00 & 07 & 99 & 99 & 99 & MAM \\
\hline Phoenix & & 01 & $\infty$ & 06 & 34 & 99 & 99 & MAM \\
\hline Phoenix & & 01 & 01 & 01 & 01 & 99 & 99 & MAM \\
\hline Phoenix & & 01 & 02 & D! & 01 & 99 & 99 & MAM \\
\hline Phoenix & & 01 & 02 & 01 & 02 & 99 & 99 & MAM \\
\hline Phoenix & & 01 & 03 & 01 & 01 & 99 & 99 & MAM \\
\hline Phoenix & & 01 & 04 & 01 & 01 & 99 & 99 & MAM \\
\hline Phoenix & & 02 & 00 & 08 & 34 & 99 & 99 & MAM \\
\hline Phoenix & & 02 & 05 & 01 & 01 & 99 & 99 & MAM \\
\hline Phoonix & & 01 & 00 & 08 & 34 & 99 & 99 & MAM \\
\hline Phoenix & & 01 & 01 & 01 & 01 & 99 & 89 & MAM \\
\hline Phoenix & & 01 & 02 & 01 & 01 & 99 & 99 & MAM \\
\hline Phoenix & & 01 & 02 & 01 & 02 & 99 & 99 & MAM \\
\hline Phoenix & & 01 & 03 & 01 & 01 & 99 & 99 & MAM \\
\hline Phoenix & & 01 & 04 & 01 & 01 & 99 & 99 & MAM \\
\hline Phoenix & & 02 & 00 & 08 & 34 & 99 & 99 & MAM \\
\hline Phoenix & & 02 & 05 & 01 & 01 & 99 & 99 & MAM \\
\hline Phoenix & & 01 & 00 & 06 & 34 & 99 & 99 & MAM \\
\hline Phoenix & & 01 & 01 & 01 & 01 & 89 & 99 & MAM \\
\hline Phoenix & & 01 & 02 & 01 & 01 & 99 & 99 & MAM \\
\hline Phoenix & & 01 & 02 & 01 & 02 & 99 & 99 & MAM \\
\hline Phoenix & & 01 & 03 & 09 & 01 & 89 & 99 & MAM \\
\hline Phoenix & & 01 & 04 & 01 & 01 & 99 & 99 & MAM \\
\hline Phoenix & & 02 & 00 & $O B$ & 34 & 89 & 89 & MAM \\
\hline Phoenix & & 02 & 05 & 01 & 01 & 99 & 99 & MAM \\
\hline Phoenix & & 01 & 02 & 03 & 17 & 10 & 99 & SJC \\
\hline Phoenix & & 01 & 02 & $\mathbf{0 j}$ & 18 & 10 & 99 & SJC \\
\hline Phoenix & & 01 & $\infty$ & 00 & 38 & 89 & 99 & MAM \\
\hline Phoenix & & 01 & 00 & $\infty$ & 34 & 99 & 99 & MAM \\
\hline Phoenix & & 01 & 01 & 01 & 01 & 89 & 99 & MAM \\
\hline Phoenix & & 01 & 02 & 01 & 01 & 89 & 99 & MAM \\
\hline Phoenix & & 01 & 02 & 01 & 02 & 99 & 99 & MAM \\
\hline Phoenix & & 01 & 03 & 01 & 01 & 89 & 99 & MAM \\
\hline Phoenix & & 01 & 04 & 01 & 01 & 80 & 99 & MAM \\
\hline Phoenix & & 02 & 00 & $0 B$ & 34 & 99 & 98 & MAM \\
\hline Phoenlx & & 02 & 05 & 01 & 01 & 99 & 89 & MAM \\
\hline Phoenix & & 01 & 00 & 08 & 34 & 99 & 89 & MAM \\
\hline Phoenix & & 01 & 01 & 01 & 01 & 99 & 89 & MAM \\
\hline Phoonix & & 01 & 02 & 01 & 01 & 99 & 99 & MAM \\
\hline Phoenix & & 01 & 02 & 01 & 02 & 99 & 99 & MAM \\
\hline Phoenix & & 01 & 03 & 01 & 01 & 89 & 99 & MAM \\
\hline Phoenix & & 01 & 04 & 01 & 01 & 99 & 89 & MAM \\
\hline Phoenix & & 02 & 00 & $\infty$ & 34 & 89 & 99 & MAM \\
\hline Phoenix & & 02 & 05 & 01 & 01 & 99 & 89 & MAM \\
\hline Phoenix & & 01 & 00 & $\infty$ & 34 & 99 & 99 & MAM \\
\hline Phoenix & & 01 & 01 & 01 & 01 & 99 & 89 & MAM \\
\hline Phoenix & & 01 & 02 & 01 & 01 & 99 & 89 & MAM \\
\hline Phoenix & & 01 & 02 & 01 & 02 & 99 & 99 & MAM \\
\hline Phoenix & & 01 & 03 & 01 & 01 & 99 & 99 & MAM \\
\hline Phoenix & & 01 & 04 & 01 & 01 & 99 & 99 & MAM \\
\hline Phoenix & & 02 & 00 & De & 34 & 99 & 89 & MAM \\
\hline Phoenix & & 02 & 05 & 01 & 01 & 99 & 99 & MAM \\
\hline Phoenix & & 01 & 00 & 08 & 34 & 99 & 99 & MAM \\
\hline Phoenix & & 01 & 01 & 01 & 01 & 99 & 99 & MAM \\
\hline Phoenix & & 01 & 02 & 01 & 01 & 99 & 99 & MAM \\
\hline Phoenix & & 01 & 02 & 01 & 02 & 99 & 99 & MAM \\
\hline Phoenix & & 01 & 03 & 01 & 01 & 89 & 99 & MAM \\
\hline Phoenix & & 01 & or & 01 & 01 & 89 & 89 & MAM \\
\hline Phoenix & & 02 & $\infty$ & Do & 34 & 99 & 99 & MAM \\
\hline & & & & & & & & \\
\hline
\end{tabular}


(00)

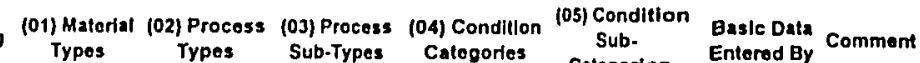

277 Hand Probe. HP.270

277 Hand Probe- HP-270

277 Hand Probe. HP. 270

Hand Probo- HP. 270

Hand Probe. HP.270

Hand Probe. HP.270

Hand Probe. HP. 270

Hand Probe. LEG.1

Hand Probo. LEG.1

Hand Probo Leg-1

Hand Probe- LEG-1

Hand Probo- LEG.

Hand Probo- LEG. 1

Hand Probo- LEG.1

Hazardous Duty Mobile Robol-Andros $4 \times 4$

Hazarsous Duty Mobile Robol- Andros BX

政

Phoonix

Identifier Calegorles

Phoenix

Phoonlx

Phoenix

Phoonix
Phoonix

Phoenlx

Phoonix

Phoenix

Phoenix

Phoenix

Phoenix

Phoenix

Phoonix

Phoenix

1 Hazardous Duty Mobile Robol. Andros Mark VI.A

Phoenix

01
01
01
01
01
01
02
02
01
01
01
01
01
01
02
02
01
02
01
02
01

$\begin{array}{ll}00 & 06 \\ 01 & 01 \\ 02 & 01 \\ 02 & 01 \\ 03 & 01 \\ 04 & 01 \\ 00 & 08 \\ 05 & 01 \\ 00 & 08 \\ 01 & 01 \\ 02 & 01 \\ 02 & 01 \\ 03 & 01 \\ 04 & 01 \\ 00 & 08 \\ 05 & 01 \\ 00 & 07 \\ 00 & 07 \\ 00 & 07 \\ 00 & 07 \\ 00 & 07\end{array}$

$\begin{array}{ll}34 & 99 \\ 01 & 99 \\ 01 & 99 \\ 02 & 99 \\ 01 & 99 \\ 01 & 99 \\ 34 & 99 \\ 01 & 99 \\ 34 & 99 \\ 01 & 99 \\ 01 & 99 \\ 02 & 99 \\ 01 & 99 \\ 01 & 99 \\ 34 & 99 \\ 01 & 99 \\ 99 & 99 \\ 99 & 99 \\ 99 & 99 \\ 99 & 99 \\ 89 & 99\end{array}$

MAM
MAM

2 Hazardous Duty Mobilo Robot-Mini Andros

Phoenix

Phoenix

Hezardous Duty Mobile Robot-MISR

Hazardous Duty Moble Robot. MISR
Hazardous Duty Mobile Robol.Andros Mark V.A

Phoenix

Phoenlx

Phoenix

Dobuty Mobile Robot-Andros Mark $V . A$

Hepa-Vacuum. Several Models

High Pressure Fivid Assisted Dall

High Range Survey System. RO-7

Hight Range Survey System. RO.7

High Range Survey System. RO.7

High Range Survey System. RO-7

High Rango Survey System. RO-7

High Range Survey System. RO-7

Highromp Vacuum Distilation of Pu Sall

HPGe Wasto Banel Analyzer- Barel Mon

HPGe Wasto Barrel Analyzer. Earrel Monitor

HydraCulter C150. Concrete Saw

HydraCutter C15a-Concrele Saw

HydraCulter C150-Concrete Saw

Hydrautle Backhoe / Craw

Hydraulic Torque Wrench

In Situ Secondary lon-Mass Spectromotry

In Situ Seconday lon-Mass Spectromety

lonization Chamber- RO-2

lonization Chamber- RO-2

Tonization Chamber- RO-2

Ionization Chamber-RO-2

lonization Chamber- RO-2

lonization Chamber. RO-2

Jelair Modet3- Ventlation Unit

Phoenix

Phoenix

Phoenix

Phoen $x$

Phoenix

Phoenix

Phoenix

Phoenix

Phoenlx
Phoenix

Phoenix

Phoenly

Phoenix

Phoenlx

Phoenix

Phoenix
Phoenix

Phoenix

Phoenix

Phoenix

Phoenix

Phonk

Phoenix

$\begin{array}{ll}07 & 99 \\ 07 & 99 \\ 07 & 99 \\ 07 & 99 \\ 07 & 99 \\ 07 & 99 \\ 06 & 34 \\ 04 & 99 \\ 06 & 34 \\ 01 & 01 \\ 01 & 01 \\ 01 & 02 \\ 01 & 01 \\ 01 & 01 \\ 06 & 34 \\ 01 & 01 \\ 99 & 99 \\ 08 & 34 \\ 01 & 01 \\ 03 & 13 \\ 03 & 14 \\ 03 & 18 \\ 04 & 99 \\ 04 & 99 \\ 04 & 99 \\ 06 & 34 \\ 06 & 34 \\ 06 & 34 \\ 01 & 01 \\ 01 & 01 \\ 01 & 02 \\ 01 & 01 \\ 01 & 01 \\ 08 & 34 \\ 01 & 09 \\ 08 & 34\end{array}$

ssc

SJC

SJC

SJC

SJC

SJC

MAM

MAM

MAM

MAM

MAM

MAM

MAM

SJC

SJC

SJC
SJC
SJC
MAM

MAM

MAM

MAM

MAM

MAM

MAM

MAM

MAM 


\begin{tabular}{|c|c|c|c|c|c|c|c|c|c|c|}
\hline Tech 10 & Technology Titlo & Data Source & $\begin{array}{l}\text { Data Source } \\
\text { Identifier }\end{array}$ & $\begin{array}{c}(00) \\
\text { Decommlssioning } \\
\text { Categories }\end{array}$ & $\begin{array}{l}\text { (01) Material } \\
\text { Types }\end{array}$ & $\begin{array}{l}\text { (02) Process } \\
\text { Types }\end{array}$ & $\begin{array}{l}\text { (03) Process } \\
\text { Sub-Types }\end{array}$ & $\begin{array}{l}\text { (01) Condition } \\
\text { Categories }\end{array}$ & $\begin{array}{l}\text { (05) Condition } \\
\text { Sub- } \\
\text { Calegories }\end{array}$ & $\begin{array}{l}\text { Basie Data } \\
\text { Entered By }\end{array}$ \\
\hline 297 & $\begin{array}{l}\text { Jetair Model-9. Ventiation Unit } \\
\text { Lersete }\end{array}$ & Phoenix & & 01 & 00 & OB & 34 & 99 & . 99 & MAM \\
\hline 298 & $\begin{array}{l}\text { Laser Ablation System for Metal } 8 \text { Concrete } \\
\text { Surface }\end{array}$ & & & 01 & 02 & 02 & 99 & 99 & 99 & suc \\
\hline 299 & Light Aided Technologies & Phoenix & & 00 & 00 & 99 & 99 & 99 & 99 & MAM \\
\hline 300 & Long Reach Scabblers- 150 5092-LR & Phoenix & & 01 & 01 & 02 & 07 & 01 & 99 & suc \\
\hline 300 & Long Reach Scabblers- 150 5092-LR & Phoenlx & & 01 & 01 & 02 & 07 & 02 & 99 & SJC \\
\hline 300 & Long Reach Scabblers- 150.5092-LR & Phoenix & & 01 & 02 & 02 & 99 & 99 & 99 & SJC \\
\hline 301 & Long Roach Scabblers- 150.5099-LR & Phoenix & & 01 & 01 & 02 & 07 & 01 & 99 & SJC \\
\hline 301 & Long Reach Scabblers- 150.5099-LR & Phoenix & & 01 & 01 & 02 & 07 & 02 & 89 & SJC \\
\hline 301 & Long Reach Scabblers-150.5099-LR & Phoenix & & 01 & 02 & 02 & 99 & 99 & 99 & SJC \\
\hline 302 & Long Reach Scalers- 136.3299-2 & Phoenix & & 01 & 01 & 02 & 07 & 99 & 99 & SJC \\
\hline 302 & Long Reach Scalors- 136.3299-2 & Phoenix & & 01 & 01 & 02 & 08 & 99 & 99 & SJC \\
\hline 302 & Long Reach Scalers- $136.3299-2$ & Phoenix & & 01 & 02 & 02 & 99 & 99 & 99 & SJC \\
\hline 303 & Long Reach Scalers- 136.3497-4 & Phoenix & & of & 01 & 02 & 07 & 99 & 99 & suc \\
\hline 303 & Long Reach Scalers - 138.3497-4 & Phoonix & & 01 & 01 & 02 & 08 & 99 & 99 & Suc \\
\hline 303 & Long Reach Sealors - 136.3497-4 & Phoenix & & 01 & 02 & 02 & 99 & 99 & 99 & Suc \\
\hline 304 & Long Reach Sealers. $1383899-6$ & Phoenix & & 01 & 01 & 02 & 07 & 99 & 99 & suc \\
\hline 304 & Long Reach Scalers. $1383899-8$ & Phoenix & & 01 & 01 & 02 & 08 & 99 & 99 & suc \\
\hline 304 & Long Reach Scalers - $1363699-8$ & Phoenix & & 01 & 02 & 02 & 99 & 99 & 99 & SJC \\
\hline 305 & Long Reach Scalers. 1373697.6 & Phoenix & & 01 & 01 & 02 & 07 & 99 & 99 & SJC \\
\hline 305 & Long Reach Scalers- 1373697.6 & Phoenix & & 01 & 01 & 02 & 08 & 99 & 99 & SJC \\
\hline 305 & Long Reach Scalers- 1373697.6 & Phoenix & & 01 & 02 & 02 & 99 & 99 & 99 & suc \\
\hline 306 & $\begin{array}{l}\text { Magnelic-Wheeled Robot for Carbon Sleel } \\
\text { Inspection- Fury }\end{array}$ & Phoonix & & 01 & 02 & 07 & 04 & 99 & 89 & SJC \\
\hline 307 & Manipulator & Phoenix & & 01 & 00 & 07 & ө9 & 99 & 99 & SJC \\
\hline 307 & Manipulalor & Phoenix & & 02 & 00 & 07 & 89 & 99 & 89 & SJC \\
\hline 300 & Mastr.PUMp NE 5 hp & Phoenix & & 02 & 07 & 08 & 99 & 99 & 99 & SJC \\
\hline 309 & Microblasting & Phoenix & & 01 & 00 & 02 & 99 & 99 & 99 & SJC \\
\hline 310 & Mini Sealer-MS.2 & Phoonix & & 00 & 00 & 99 & 99 & 99 & 99 & MAM \\
\hline 311 & Minlature.Slzed. Real-Time Radiation Detector & Phoenix & & 01 & 00 & 08 & 34 & $\mathbf{9 9}$ & 99 & MAM \\
\hline 311 & Minlature.Sized, Real-Time Radiation Detector & Phoenix & & 01 & 01 & 01 & 01 & 99 & 99 & MAM \\
\hline 311 & Miniature-Sized, Real-Time Radiation Dolector & Phoenix & & 01 & 02 & 01 & 01 & 99 & 99 & MAM \\
\hline 311 & Miniature-Sized, Real-Time Radiation Delector & Phoenix & & 01 & 02 & 01 & 02 & 99 & 99 & MAM \\
\hline 311 & Minature-Sized, Real-Time Radiation Detector & Phoenix & & 01 & 03 & 01 & 01 & 99 & 99 & MAM \\
\hline 311 & & Phoenix & & 01 & 04 & 01 & 01 & 99 & 99 & MAM \\
\hline 311 & Minialure.Sized. Real-Time Radiation Dotector & Phoenix & & 02 & 00 & $\infty$ & 34 & 99 & 99 & MAM \\
\hline 311 & & Phoenix & & 02 & 05 & 01 & 01 & 99 & 99 & MAM \\
\hline 312 & Mobile Cart Air Sampler- MRV. 0523CV & Phoenlx & & 01 & 00 & 01 & 01 & 99 & 99 & MAM \\
\hline 312 & Mobile Cart Air Sampler- MRV-0523CV & Phoenix & & 01 & 00 & 08 & 34 & 99 & 99 & MAM \\
\hline 313 & Mobile Facilhy-MDF=120 & Phoenix & & 01 & 00 & 02 & 99 & 99 & 99 & SJC \\
\hline 313 & Mobile Facility-MDF.120 & Phoenix & & 01 & 02 & 02 & 99 & 99 & 99 & sJc \\
\hline 314 & Mobile Otfico-MO208 & Phoenix & & $\infty 0$ & 00 & 99 & 99 & 99 & 89 & MAM \\
\hline 315 & Mobile Radiation Dotection \& Mapping System- & Phoenix & & 02 & 00 & $\infty$ & 34 & 99 & 99 & MAM \\
\hline 315 & $\begin{array}{l}\text { Insilu Soll Assay System } \\
\text { Mobile Radiation Detection \& Mapping System. } \\
\text { Insitu Soil Assay System }\end{array}$ & Phoenix & & 02 & 05 & 01 & 01 & 99 & 99 & MAM \\
\hline 315 & $\begin{array}{l}\text { Mobile Radiation Dotection \& Mapping System- } \\
\text { Insitu Soil Assay System }\end{array}$ & Phoenix & & 02 & 05 & 01 & 05 & 99 & 99 & MAM \\
\hline 316 & Mult Stripper- BMS-1000 & Phoenix & & 01 & 00 & 02 & 99 & 99 & 99 & suc \\
\hline 317 & Needle Scaler- 110.1099-18 & Phoenix & & 01 & 01 & 02 & 07 & 02 & 03 & ssc \\
\hline 317 & Needle Scaler- 110.1099-18 & Phoenix & & 01 & 01 & 02 & 08 & 01 & 03 & sJc \\
\hline 317 & Needie Scaler- $1101099-18$ & Phoenix & & 01 & 01 & 02 & 08 & 02 & 03 & SJC \\
\hline 317 & Needio Scaler. 110 1099-18 & Phoenix & & 01 & 02 & 02 & 99 & 99 & 99 & SJC \\
\hline 318 & Needle Scaler 141.4099-4B & Phoenix & & 01 & 01 & 02 & 07 & 02 & 03 & SJC \\
\hline 318 & Needle Scaler. 141 4099-4B & Phoenix & & 01 & 01 & 02 & 08 & 01 & 03 & SJC \\
\hline 318 & Needis Scaler 141 4099-4B & Phoenix & & 01 & 01 & 02 & 08 & 02 & 03 & SJC \\
\hline 318 & Needie Scaler 141.4099-4B & Phoenix & & 01 & 02 & 02 & 99 & 99 & 89 & SJC \\
\hline 319 & Needie Scaler-Comer-Cutter & Phoenix & & 01 & 01 & 02 & 07 & 02 & 03 & SJC \\
\hline 319 & Needie Scaler-Comer-Cutter & Phoenix & & 01 & 01 & 02 & 08 & 01 & 03 & suc \\
\hline 319 & Needio Scalar. Comer-Cutter & Phoenix & & 01 & 01 & 02 & 08 & 02 & 03 & SJC \\
\hline
\end{tabular}




\begin{tabular}{|c|c|c|c|c|c|c|c|c|c|c|}
\hline Toch ID & Technology nitlo & Data Source & $\begin{array}{l}\text { Data Source } \\
\text { Identller }\end{array}$ & $\begin{array}{c}(00) \\
\text { Decommissioning } \\
\text { Categorios }\end{array}$ & $\begin{array}{l}\text { (01) Matorial } \\
\text { Types }\end{array}$ & $\begin{array}{l}\text { (02) Process } \\
\text { Types }\end{array}$ & $\begin{array}{l}\text { (03) Procoss } \\
\text { Sub-Types }\end{array}$ & $\begin{array}{l}\text { (04) Condition } \\
\text { Catogorios }\end{array}$ & $\begin{array}{l}\text { (05) Condition } \\
\text { Sub. } \\
\text { Categaries }\end{array}$ & $\begin{array}{l}\text { Basic Dat } \\
\text { Enterod } 8\end{array}$ \\
\hline 319 & Neodlo Scaler- Comer.Culler & Phoenix & & 01 & 02 & 02 & 99 & 99 & 99 & s.JC \\
\hline 320 & Needio Scaler-Van Arx NP.34 & Phoenix & & 01 & 01 & 02 & 07 & 02 & 03 & SJC \\
\hline 320 & Needlo Scaler. Van Arx NP.34 & Phoonlx & & 01 & 01 & 02 & $0 B$ & 01 & 03 & SJC \\
\hline 320 & Needle Scaler. Van Arx NP.34 & Phoenix & & 01 & 01 & 02 & 08 & 02 & 03 & SJC \\
\hline 320 & Needle Scaler-Van Arx NP.34 & Phoenix & & 01 & 02 & 02 & 99 & 89 & 99 & SJC \\
\hline 321 & Personal Air Sampler - 08-430 & Phoenix & & 01 & 00 & 00 & 34 & 99 & 99 & MAM \\
\hline 322 & Pipe Culler & Phoenix & & 01 & 02 & 03 & 17 & 10 & 99 & Suc \\
\hline 323 & Plasma Cutting System, Thermal Arc 500 & Phoenix & & 01 & 02 & 03 & 17 & 09 & 99 & suc \\
\hline 323 & ' Plasma Cutting Syslem, Thermal Are 500 & Phoenix & & 01 & 02 & 03 & 19 & 09 & 99 & SUC \\
\hline 324 & $\begin{array}{l}\text { Plasma Cuttiing System, Thermal ArC PAK 10XR } \\
\text { Pak }\end{array}$ & Phoenlx & & 01 & 02 & 03 & 17 & 09 & 99 & SJC \\
\hline 324 & Plasma Cutthing System, Thermal Arc PAK 10XR & Phoenix & & 01 & 02 & 03 & 19 & 09 & 99 & SUC \\
\hline 325 & Plasma Cutting Systom, Thermal Arc PAK 14 & Phoenix & & 01 & 02 & 03 & 17 & 09 & 99 & S.JC \\
\hline 325 & Plasma Cutting System, Thermal Arc PAK 44 & Phoenix & & 01 & 02 & 03 & 19 & 09 & 89 & S.JC \\
\hline 326 & Plasma Cutting System. Thermal Arc PAK 15 & Phoonix & & 01 & 02 & 03 & 17 & 09 & 99 & SJC \\
\hline 326 & Plasma Cutting System, Thermal Arc PAK 15 & Phoenix & & 01 & 02 & 03 & 19 & 09 & 99 & SJC \\
\hline 327 & Plasma Torch & Phoenlx & & 01 & 02 & 03 & 18 & 09 & 99 & SJC \\
\hline 327 & Plasma Torch & Phoenix & & 01 & 02 & 03 & 17 & 09 & 99 & SJC \\
\hline 327 & Plasma Torch & Phoenix & & 01 & 02 & 03 & 18 & 09 & 99 & SJC \\
\hline 327 & Plasma Torch & Phoonix & & 01 & 02 & 03 & 19 & 09 & 89 & $\mathrm{SJC}$ \\
\hline 328 & Plasma-Mass Spectrometry - ICP-MS & Phoenix & & $\infty$ & 00 & 89 & 99 & 99 & 99 & MAM \\
\hline 329 & Pneumatic Nibblers- $N$ 1000-1 & Phoenix & & 01 & 02 & 03 & 18 & 10 & 99 & SJC \\
\hline 329 & Pneumalic Nibblors-N 1000-1 & Phoenix & & 01 & 02 & 03 & 17 & 10 & 99 & SJC \\
\hline 329 & Pneumatic Nibblers. N 1000-1 & Phoenix & & 01 & 02 & 03 & 18 & 10 & 99 & SJC \\
\hline 329 & Pneumalic Nibblers. $N$ 1000-1 & Phoenix & & 01 & 02 & 03 & 19 & 10 & 99 & Sנc \\
\hline 330 & Pneumalic Nibblers- N $500-5$ & Phoenix & & 01 & 02 & 03 & 18 & 10 & 99 & Suc \\
\hline 330 & Pneumatic Nibblers- N 500.5 & Phoenix & & 01 & 02 & 03 & 17 & 10 & 99 & SJC \\
\hline 330 & Pneumalic Nibblers- N $500-5$ & Phoenix & & 01 & 02 & 03 & 18 & 10 & 99 & s.JC \\
\hline 330 & Pneumalic Nibblers-N $500-5$ & Phoenix & & 01 & 02 & 03 & 19 & 10 & 99 & SJC \\
\hline 331 & Pneumatic Nibblers- N 700-1 & Phoenix & & 01 & 02 & 03 & 18 & to & 99 & suc \\
\hline 331 & Pneumatic Nibblers- $\mathrm{N} 700-1$ & Phoenix & & 01 & 02 & 03 & 17 & 10 & 99 & suc \\
\hline 331 & Pneumalic Nibblers- N 700-1 & Phoenlx & & 01 & 02 & 03 & 18 & 10 & 99 & SJC \\
\hline 331 & Pneumatic Nibblers- $\mathrm{N} 700-1$ & Phoenix & & 01 & 02 & 03 & 19 & 10 & 99 & SJC \\
\hline 332 & $\begin{array}{l}\text { Pneumalic Pipe CutteriBeveler. SF } 408 \text { (Split } \\
\text { Frame) }\end{array}$ & Phoenix & & 01 & 02 & 03 & 18 & 10 & 99 & sJc \\
\hline 333 & Pneumatic Shears. $\mathbf{S} 420.1$ & Phoenix & & 01 & 02 & 03 & 10 & 10 & 99 & suc \\
\hline 333 & Pnoumatic Shears- 5 420-1 & Phoenix & & 01 & 02 & 03 & 18 & 10 & 99 & Suc \\
\hline 334 & $\begin{array}{l}\text { Portable Blast Cleaning System ( } 1.100 \text { w/dust } \\
\text { collector) }\end{array}$ & Phoenix & & 01 & 01 & 02 & 07 & 01 & 03 & suc \\
\hline 334 & $\begin{array}{l}\text { Portable Btast Cleaning System ( } 1-100 \text { w/dust } \\
\text { collector) }\end{array}$ & Phoenix & & 01 & 01 & 02 & 08 & 01 & 03 & suc \\
\hline 334 & $\begin{array}{l}\text { Portable Blast Cleaning System (1-10D w/dust } \\
\text { collector) }\end{array}$ & Phoenix & & 01 & 01 & 02 & 08 & 02 & 03 & s.sc \\
\hline 334 & $\begin{array}{l}\text { Pontable Blast Cleaning System (1-100 w/dust } \\
\text { collector) }\end{array}$ & Phoenix & & 01 & 02 & 02 & 09 & 89 & 89 & suc \\
\hline 334 & $\begin{array}{l}\text { Portable Blast Cleaning System ( }(-10 \mathrm{D} \text { w/dust } \\
\text { collector) }\end{array}$ & Phoenix & & 01 & 02 & 02 & 10 & 03 & 99 & suc \\
\hline 334 & $\begin{array}{l}\text { Portable Blast Cleaning System (1-10D w/dust } \\
\text { collector) }\end{array}$ & Phoenix & & 01 & 02 & 02 & 10 & 04 & 99 & suc \\
\hline 334 & $\begin{array}{l}\text { Portable Blast Cleaning System (1-100 w/dust } \\
\text { collector) }\end{array}$ & Phoenix & & 01 & 02 & 02 & 11 & 05 & 02 & suc \\
\hline 334 & $\begin{array}{l}\text { Portable Blast Cleaning System (1-100 w/dust } \\
\text { collector) }\end{array}$ & Phoenix & & 01 & 02 & 02 & 11 & 06 & 02 & suc \\
\hline 334 & $\begin{array}{l}\text { Portable Blast Cleaning System (1-100 w/dust } \\
\text { collector) }\end{array}$ & Phoenix & & 01 & 02 & 02 & 12 & 07 & 99 & sJc \\
\hline 334 & $\begin{array}{l}\text { Portable Blast Cleaning System (1-100 w/dust } \\
\text { collector) }\end{array}$ & Phoenix & & 01 & 02 & 02 & 12 & 08 & 99 & suc \\
\hline 334 & $\begin{array}{l}\text { Portable Blast Cleaning System ( } 1-100 \text { w/dust } \\
\text { collector) }\end{array}$ & Phoenix & & 01 & 02 & 02 & 12 & 89 & 99 & suc \\
\hline 335 & $\begin{array}{l}\text { Portablo Blast Cleaning System (1.15D w/dust } \\
\text { collector) }\end{array}$ & Phoenix & & 01 & 09 & 02 & 07 & 01 & 03 & SJC \\
\hline
\end{tabular}




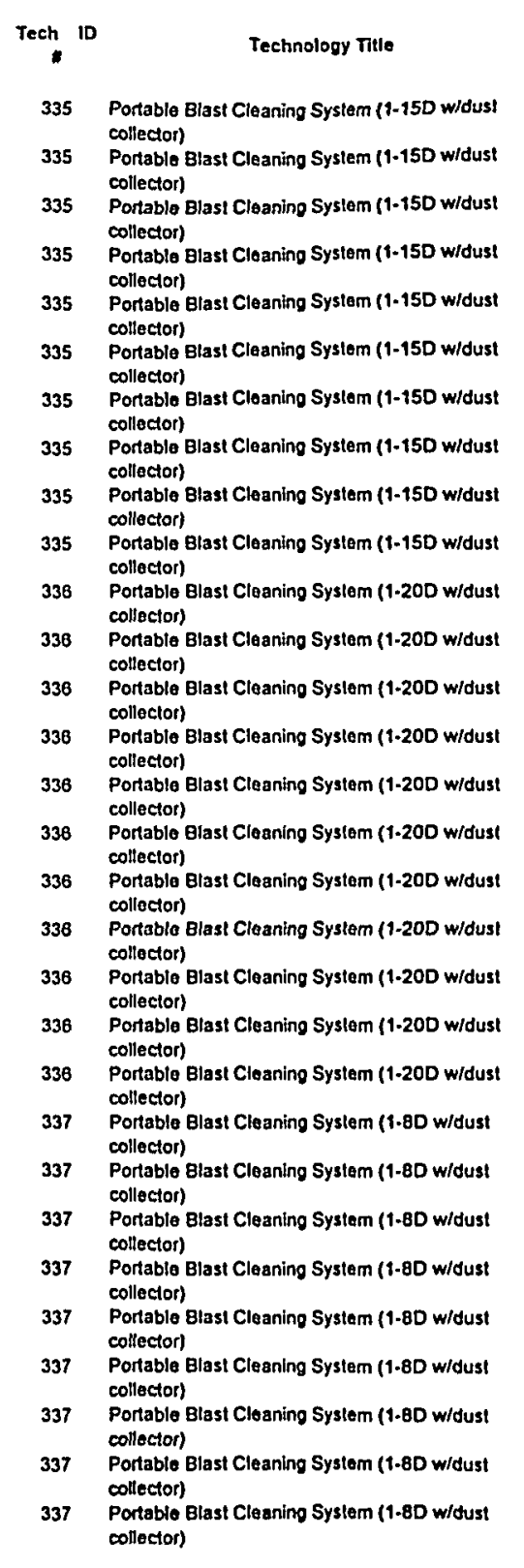

\begin{tabular}{|c|c|c|c|c|c|c|c|c|}
\hline Dala Sourco & $\begin{array}{l}\text { Data Source } \\
\text { Identifier }\end{array}$ & $\begin{array}{l}(00) \\
\text { Decommissioning } \\
\text { Categories }\end{array}$ & $\begin{array}{l}\text { (01) Material } \\
\text { Types }\end{array}$ & $\begin{array}{l}\text { (02) Process } \\
\text { Types }\end{array}$ & $\begin{array}{l}\text { (03) Process } \\
\text { Sub-Types }\end{array}$ & $\begin{array}{l}\text { (04) Condition } \\
\text { Categories }\end{array}$ & $\begin{array}{l}\text { (05) Condition } \\
\text { Sub. } \\
\text { Categories }\end{array}$ & $\begin{array}{l}\text { Basic Data } \\
\text { Entered By }\end{array}$ \\
\hline Phoenix & & 01 & 01 & 02 & 08 & 01 & 03 & SNC \\
\hline Phoenix & & 01 & 01 & 02 & 08 & 02 & 03 & SUC \\
\hline Phoenix & & 01 & 02 & 02 & 09 & 99 & 99 & suc \\
\hline Phoenix & & 01 & 02 & 02 & 10 & 03 & 99 & Suc \\
\hline Phoenix & & 01 & 02 & 02 & 10 & 04 & 99 & SIC \\
\hline Phoenix & & 01 & 02 & 02 & 11 & 05 & 02 & SJC \\
\hline Phoenix & & 01 & 02 & 02 & 11 & 06 & 02 & SJC \\
\hline Phoenix & & 01 & 02 & 02 & 12 & 07 & 99 & SJC \\
\hline Phoenix & & 01 & 02 & 02 & 12 & 08 & 99 & sJc \\
\hline Phoenix & & 01 & 02 & 02 & 12 & 99 & 99 & SJC \\
\hline Phoenix & & 01 & 01 & 02 & 07 & 01 & 03 & sJc \\
\hline Phoenix & & 01 & 01 & 02 & 08 & 01 & 03 & sJc \\
\hline Phoenix & & 01 & 01 & 02 & 08 & 02 & 03 & suc \\
\hline Phoonix & & 01 & 02 & 02 & 09 & 99 & 99 & SJC \\
\hline Phoenix & & 01 & 02 & 02 & 10 & 03 & 99 & SJC \\
\hline Phoenix & & 01 & 02 & 02 & 10 & 04 & 99 & suc \\
\hline Phoenix & & 01 & 02 & 02 & 11 & 05 & 02 & suc \\
\hline Phoonix & & 01 & 02 & 02 & 11 & 08 & 02 & SJC \\
\hline Phoenix & & 01 & 02 & 02 & 12 & 07 & 89 & SJC \\
\hline Phoenix & & 01 & 02 & 02 & 12 & 08 & 89 & suc \\
\hline Phoenix & & 01 & 02 & 02 & 12 & 99 & 89 & sjc \\
\hline Phoenix & & 01 & 01 & 02 & 07 & 01 & 03 & SJC \\
\hline Phoenix & & 01 & 01 & 02 & 08 & 01 & 03 & sJC \\
\hline Phoonix & & 01 & 01 & 02 & 08 & 02 & 03 & suc \\
\hline Phoenix & & 01 & 02 & 02 & 09 & 89 & 89 & suc \\
\hline Phoonix & & 01 & 02 & 02 & 10 & 03 & 99 & sJc \\
\hline Phoenix & & 01 & 02 & 02 & 10 & 04 & 99 & suc \\
\hline Phoenix & & 01 & 02 & 02 & 11 & 05 & 02 & sJc \\
\hline Phoenix & & 01 & 02 & 02 & 11 & $\infty$ & 02 & suc \\
\hline Phoenix & & 01 & 02 & 02 & 12 & 07 & 99 & SJC \\
\hline
\end{tabular}




\begin{tabular}{|c|c|}
\hline och 1 & Technology Ttle \\
\hline 337 & $\begin{array}{l}\text { Portablo Blast Cloaning Syslom ( } 1.80 \text { w/dust } \\
\text { collector) }\end{array}$ \\
\hline 337 & $\begin{array}{l}\text { Portablo Blast Cleaning System ( } 1.80 \text { w/dust } \\
\text { colloctor) }\end{array}$ \\
\hline 338 & $\begin{array}{l}\text { Portable Elast Cleaning System (1.8DEC w/dust } \\
\text { collector) }\end{array}$ \\
\hline 338 & $\begin{array}{l}\text { Portablo Elast Cleanino Syslem (1.8DEC w/dust } \\
\text { collector) }\end{array}$ \\
\hline 338 & $\begin{array}{l}\text { Portable Blast Cleaning Syslem (1-80EC w/dust } \\
\text { collector) }\end{array}$ \\
\hline 338 & $\begin{array}{l}\text { Portable Blast Cleaning Syslem (1.8DEC w/dusi } \\
\text { collector) }\end{array}$ \\
\hline 338 & $\begin{array}{l}\text { Portablo Blast Cleaning System (1-8DEC w/dust } \\
\text { collector) }\end{array}$ \\
\hline 338 & $\begin{array}{l}\text { Portable Blast Cleaning System (1-8DEC w/dust } \\
\text { collector) }\end{array}$ \\
\hline 338 & $\begin{array}{l}\text { Portable Blast Cleaning System (1.80EC w/dust } \\
\text { collactor) }\end{array}$ \\
\hline 338 & $\begin{array}{l}\text { Portable Blast Cleaning System (1.8DEC w/dust } \\
\text { colloctor) }\end{array}$ \\
\hline 338 & $\begin{array}{l}\text { Portable Blast Cleantng Syslom (1-8DEC w/dust } \\
\text { collector) }\end{array}$ \\
\hline 338 & $\begin{array}{l}\text { Portable Blast Cleaning System (1-8DEC w/dust } \\
\text { collector) }\end{array}$ \\
\hline 338 & $\begin{array}{l}\text { Portable Blast Cleaning System (1-8DEC w/dust } \\
\text { collector) }\end{array}$ \\
\hline 339 & $\begin{array}{l}\text { Porlable Elast Cleaning System (1-8S w/dust } \\
\text { collector) }\end{array}$ \\
\hline 339 & $\begin{array}{l}\text { Portable Blast Cleaning Syslom (1-8S w/dust } \\
\text { collector) }\end{array}$ \\
\hline 339 & $\begin{array}{l}\text { Portabla Blast Cleaning Systom (1-8S w/dust } \\
\text { collector) }\end{array}$ \\
\hline 339 & $\begin{array}{l}\text { Portable Blast Cleaning System (1-8S w/dust } \\
\text { colleclor) }\end{array}$ \\
\hline 339 & $\begin{array}{l}\text { Portable Blast Cleaning System (1-8S w/dust } \\
\text { collector) }\end{array}$ \\
\hline 339 & $\begin{array}{l}\text { Portable Blast Cleaning Syslom (1-8S w/dust } \\
\text { collector) }\end{array}$ \\
\hline 339 & $\begin{array}{l}\text { Portable Blast Cleaning Syslem (1-8S w/dust } \\
\text { collector) }\end{array}$ \\
\hline 339 & $\begin{array}{l}\text { Portable Blasi Cleaning System (1-8S w/dusi } \\
\text { collector) }\end{array}$ \\
\hline 339 & $\begin{array}{l}\text { Portable Blast Cleaning System (1-8S w/dust } \\
\text { collector) }\end{array}$ \\
\hline 33 & $\begin{array}{l}\text { Portable Blast Cleaning System (1-8S w/dust } \\
\text { colliector) }\end{array}$ \\
\hline 3 & $\begin{array}{l}\text { Portable Blast Cleaning Syslem (1-8S w/dust } \\
\text { colloctor) }\end{array}$ \\
\hline $\begin{array}{l}340 \\
340\end{array}$ & $\begin{array}{l}\text { Portable Blast Cleaning System (1-9DES), electric } \\
\text { Portable Elast Cleaning System (1-9DES), electric }\end{array}$ \\
\hline 340 & Portable Blast Cleaning System (1-9DES), electic \\
\hline 340 & Portable Blast Cleaning System (1-9DES), electric \\
\hline $\begin{array}{l}340 \\
340\end{array}$ & $\begin{array}{l}\text { Portablo Blast Cleaning System (1-9DES), electric } \\
\text { Portable Blast Cleaning System (1-9DES), electric }\end{array}$ \\
\hline 340 & Portable Blast Cleaning System (1-9DES), electic \\
\hline 340 & Portable Blast Cleaning System (1-9DES), electric \\
\hline 340 & Portable Blast Cleaning System (1-9DES), fectric \\
\hline 340 & $\begin{array}{l}\text { Portablo Elast Cleaning System (1-9DES), electric } \\
\text { Portable Blast Cleaning Systom (1-9DES), electric }\end{array}$ \\
\hline 341 & Portablo Blast Cleaning System (1-90ES). \\
\hline
\end{tabular}

\begin{tabular}{|c|c|c|c|c|c|c|c|c|}
\hline Data Sourco & $\begin{array}{l}\text { Data Source } \\
\text { Identifier }\end{array}$ & $\begin{array}{l}\text { (00) } \\
\text { Decommissioning } \\
\text { Categorles }\end{array}$ & $\begin{array}{l}\text { (01) Material } \\
\text { Typoss }\end{array}$ & $\begin{array}{c}\text { 102) Process } \\
\text { Types }\end{array}$ & $\begin{array}{l}\text { (03) Process } \\
\text { Sub. Types }\end{array}$ & $\begin{array}{l}\text { (04) Condilion } \\
\text { Categorios }\end{array}$ & $\begin{array}{l}\text { (05) Conditlon } \\
\text { Sub. } \\
\text { Calogorlos }\end{array}$ & $\begin{array}{l}\text { Basic De } \\
\text { Entered }\end{array}$ \\
\hline Phoenix & & 01 & 02 & 02 & 12 & 08 & 89 & SUc \\
\hline Phoenix & & 01 & 02 & 02 & 12 & 99 & 99 & SJC \\
\hline Phoenix & & 01 & 01 & 02 & 07 & 01 & 03 & SJC \\
\hline Phoenix & & 01 & 01 & 02 & 08 & 01 & 03 & SJC \\
\hline Phoenix & & 01 & 01 & 02 & 08 & 02 & 03 & sJc \\
\hline Phoenix & & 01 & 02 & 02 & 09 & 99 & 99 & SJC \\
\hline Phoenix & & 01 & 02 & 02 & 10 & 03 & 99 & suc \\
\hline Phoonix & & 01 & 02 & 02 & 10 & 04 & 99 & sJc \\
\hline Phoonix & & 01 & 02 & 02 & 11 & 05 & 02 & SJC \\
\hline Phoenix & & 01 & 02 & 02 & 11 & 08 & 02 & SJC \\
\hline Phoenix & & 01 & 02 & 02 & 12 & 07 & 99 & SJC \\
\hline Phoenix & & 01 & 02 & 02 & 12 & 08 & 99 & SJC \\
\hline Phoonix & & 01 & 02 & 02 & 12 & 99 & 99 & Suc \\
\hline Phoenix & & 01 & 01 & 02 & 07 & 01 & 03 & SJC \\
\hline Phoonix & & 01 & 01 & 02 & 08 & 01 & 03 & SJC \\
\hline Phoenix & . & 01 & 01 & 02 & 08 & 02 & 03 & SJC \\
\hline Phoenix & & 01 & 02 & 02 & 09 & 89 & 89 & SJC \\
\hline Phoenix & & 01 & 02 & 02 & 10 & 03 & 99 & SJC \\
\hline Phoenix & & 01 & 02 & 02 & 10 & 04 & 99 & SJC \\
\hline Phoen:x & & 01 & 02 & 02 & 11 & 05 & 02 & suc \\
\hline Phoenix & & 01 & 02 & 02 & 11 & 08 & 02 & suc \\
\hline Phoenix & & 01 & 02 & 02 & 12 & 07 & 99 & suc \\
\hline Phoenix & . & 01 & 02 & 02 & 12 & 08 & 89 & SJC \\
\hline Phoenix & & 01 & 02 & 02 & 12 & 99 & 89 & Suc \\
\hline Phoenix & - & 01 & 01 & 02 & 07 & 01 & 03 & IC \\
\hline Phoenix & & 01 & 01 & 02 & 08 & $\begin{array}{l}01 \\
02\end{array}$ & $\begin{array}{l}03 \\
03\end{array}$ & 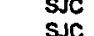 \\
\hline Phoenix & & 0 & 02 & 02 & 09 & 99 & 99 & SJC \\
\hline Phoenix & & 01 & 02 & 02 & 10 & 03 & 89 & S.JC \\
\hline Phoenix & & 01 & 02 & 02 & 10 & 04 & 89 & SJC \\
\hline Phoenix & & 01 & 02 & 02 & 11 & 05 & 02 & SJC \\
\hline Phoenix & & of & 02 & 02 & 11 & 08 & 02 & Ssc \\
\hline Phoenix & & 01 & 02 & 02 & 12 & 07 & 89 & SJC \\
\hline Pnowix & & 01 & 02 & 02 & 12 & 08 & 99 & SJC \\
\hline Phoenix & & 01 & 02 & 02 & 12 & 99 & 99 & SJC \\
\hline Phoenix & & 01 & 01 & 02 & 07 & 01 & 03 & SJC \\
\hline
\end{tabular}




\begin{tabular}{|c|c|c|c|c|c|c|c|c|c|c|}
\hline Teeh 10 & Technology nitlo & Data Source & $\begin{array}{l}\text { Data Source } \\
\text { identifier }\end{array}$ & $\begin{array}{c}(00) \\
\text { Decommissioning } \\
\text { Categories }\end{array}$ & $\begin{array}{l}\text { (01) Material } \\
\text { Types }\end{array}$ & $\begin{array}{l}\text { (02) Process } \\
\text { Types }\end{array}$ & $\begin{array}{l}\text { (03) Process } \\
\text { Sub-Types }\end{array}$ & $\begin{array}{l}\text { (04) Condition } \\
\text { Categories }\end{array}$ & $\begin{array}{l}\text { (05) Condition } \\
\text { Sub. } \\
\text { Catogories }\end{array}$ & $\begin{array}{l}\text { Basle Data } \mathrm{cc} \\
\text { Entered By }\end{array}$ \\
\hline 341 & Portable Blast Cleaning System (1-9DES). & Phoenix & & 01 & 01 & 02 & & 01 & 03 & suc \\
\hline 341 & Portablo Blast Cleaning System (1-9DES). & Phoenix & & 01 & 01 & 02 & 08 & 02 & 03 & suc \\
\hline 341 & Portable Blsst Cleaning System (1-9DES). & Phoenlx & & 01 & 02 & 02 & 09 & 99 & 99 & SJC \\
\hline 341 & Portable Blast Cleaning System (1-9DES). & Phoenix & & 01 & 02 & 02 & 10 & 03 & 99 & suc \\
\hline 341 & Portable Blast Cleaning System (1-9DES). & Phoenix & & 01 & 02 & 02 & 10 & 04 & 99 & SIC \\
\hline 341 & Portable Blast Cleaning System (1-9DES). & Phoeenlx & & 01 & 02 & 02 & 11 & 05 & 02 & SIC \\
\hline 341 & Portable Blast Cleaning System (1.9DES). & Phoenlx & & 01 & 02 & 02 & 11 & 08 & 02 & ssc \\
\hline 341 & Portablo Blast Cleaning System (1-9DES). & Phoenix & & 01 & 02 & 02 & 12 & 07 & 99 & suc \\
\hline 341 & Porlable Blast Cleaning System (1.9DES). & Phoenix & & 01 & 02 & 02 & 12 & 08 & 99 & SJC \\
\hline 341 & 'Portable 8last Cloaning System (1-9DES). & Phoenlx & & 01 & 02 & 02 & 12 & 99 & 99 & suc \\
\hline 342 & Portablo Cul-Orf Saw-Wackor BiS-11 & Phoenlx & $\cdot$ & 01 & 01 & 03 & 15 & 99 & 99 & SJC \\
\hline 342 & Portable Cut-OH Saw-Wacker BTS-11 & Phoenlx & & 01 & 02 & 03 & 17 & 10 & 99 & suc \\
\hline 342 & Portable Cul-Ort Saw. Wacker BTS-11 & Phoenix & & 01 & 02 & 03 & 18 & 10 & 89 & suc \\
\hline 342 & Portable Cut-Ont Saw-Wacker BTS-11 & Phoenix & & 01 & 02 & 03 & 19 & 10 & 99 & s.c \\
\hline 343 & & Phoenix & & 01 & 00 & 07 & 99 & 99 & 99 & MAM \\
\hline 344 & Portable Generator. Wacker G $3.7 \mathrm{~A}$ & Phoenix & & 01 & 00 & 07 & 99 & 99 & 99 & MAM \\
\hline 345 & Portablo Gonorator-Wacker G 5.6A & Phoonix & & 01 & $\infty 0$ & 07 & 99 & 89 & 99 & MAM \\
\hline 348 & & Phoenix & & 01 & $\infty$ & 07 & 99 & 99 & 99 & MAM \\
\hline 347 & Portable Lead Analyzer. Pb Analyzer & Phoenix & & 01 & 01 & 01 & 01 & 11 & 99 & MAM \\
\hline 347 & Portable Load Analyzer- Pb Analyzer & Phoenix & & 01 & 01 & 01 & 01 & 12 & 99 & MAM \\
\hline 347 & Portablo Lead Analyzer. Pb Analyzer & Phoenix & & 01 & 02 & 01 & 09 & 11 & 99 & MAM \\
\hline 347 & Portablo Lead Analyzer. Pb Analyzer & Phoenix & & 01 & 02 & 01 & 01 & 12 & 99 & MAM \\
\hline 347 & Portable Lead Analyzer. Po Analyzer & Phoenix & & 01 & 03 & 01 & 01 & 11 & 99 & MAM \\
\hline 347 & Portablo Lead Analyzer. Pb Analyzer & Phoenlx & & 01 & 03 & 01 & 01 & 12 & 99 & MAM \\
\hline 347 & Portable Lead Analyzer. Pb Analyzer & Phoenix & & 02 & 05 & 01 & 99 & 99 & 89 & MAM \\
\hline 348 & $\begin{array}{l}\text { Portable LIN-LOG Gas Proportional Alpha Counter } \\
\text { PAC-4G-3 }\end{array}$ & Phoenix & & 01 & 00 & 06 & 34 & 99 & 89 & MAM \\
\hline 348 & $\begin{array}{l}\text { Portable LIN-LOG Gas Proportional Alpha Counter } \\
\text { PAC-4G.3 }\end{array}$ & Phoenix & & 01 & 01 & 01 & 01 & 99 & 99 & MAM \\
\hline 348 & $\begin{array}{l}\text { Portable LIN-LOG Gas Proportional Alpha Counter } \\
\text { PAC-4G-3 }\end{array}$ & Phoenix & & 01 & 02 & 01 & 01 & 89 & 99 & MAM \\
\hline 348 & $\begin{array}{l}\text { Portable LIN-LOG Gas Proportional Alpha Counter } \\
\text { PAC-4G-3 }\end{array}$ & Phoenix & & 01 & 02 & 01 & 02 & 89 & 99 & MAM \\
\hline 348 & $\begin{array}{l}\text { PAC-4G.3 } \\
\text { PAC-4G.3 }\end{array}$ & Phoentx & & 01 & 03 & 01 & 01 & 99 & 99 & MAM \\
\hline 348 & $\begin{array}{l}\text { Porlable LIN.LOG Gas Proportional Alpha Counter } \\
\text { PAC-4G-3 }\end{array}$ & Phoenix & & 01 & 04 & 01 & 01 & 99 & 99 & MAM \\
\hline 348 & $\begin{array}{l}\text { Pontablo LIN.LOG Gas Proportional Alpha Counter } \\
\text { PAC-4G.3 }\end{array}$ & Phoenlx & & 02 & 00 & 00 & 34 & 99 & 99 & MAM \\
\hline 348 & $\begin{array}{l}\text { Portable LIN.LOG Gas Proportional Alpha Counter } \\
\text { PAC.4G-3 }\end{array}$ & Phoenix & & 02 & 05 & 01 & 01 & 89 & 99 & MAM \\
\hline 349 & Portable Ion Chamber. PIC-6B & Phoenix & & 01 & 00 & $\infty 8$ & 34 & 89 & $9 \theta$ & MAM \\
\hline 349 & Porlable Ion Chamber. PIC-68 & Phoenix & & 01 & 01 & 01 & 01 & 99 & 99 & MAM \\
\hline 349 & Portable Ion Chamber. PIC-6B & Phoenix & & 01 & 02 & 01 & 01 & 99 & 99 & MAM \\
\hline 349 & Portablo lon Chamber- PIC-6B & Phoenix & & 01 & 02 & 01 & 02 & 89 & 99 & MAM \\
\hline 349 & Portablo lon Chamber- PIC-6B & Phoenix & & 01 & 03 & 01 & 01 & 99 & 89 & MAM \\
\hline 349 & Portable lon Chamber- PIC-8B & Phoenlx & & 01 & 04 & 01 & 01 & 89 & 99 & MAM \\
\hline 349 & Portablo lon Chrmber. PIC. 8 B & Phoenlix & & 02 & $\infty$ & 08 & 34 & 99 & 89 & MAM \\
\hline 349 & Portable Ion Chamber. PIC-6B & Phoentx & & 02 & 05 & 01 & 01 & 99 & 89 & MAM \\
\hline 350 & Portablo Micro "R" Meter - ASP-1/SPA-8 & Phoenix & & 01 & $\infty$ & $\infty$ & 34 & 99 & 99 & MAM \\
\hline 350 & Portablo Micro " $R$ " Meter - ASP.1/SPA.B & Phoenlx & & 01 & 01 & 01 & 01 & 99 & 99 & MAM \\
\hline 350 & Porlablo Miero "R" Meter - ASP-1/SPA-B & Phoontx & & 01 & 02 & 01 & 01 & 99 & 99 & MAM \\
\hline 350 & Portable Micro "R" Meter - ASP.1/SPA-B & Phoonix & & 01 & 02 & 01 & 02 & 99 & 99 & MAM \\
\hline 350 & Portablo Micro " $\mathrm{R}$ " Meter - ASP-1/SPA.B & Phoentx & & 01 & 03 & 01 & 01 & 99 & 99 & MAM \\
\hline 350 & Portable Micro "R" Meter - ASP-1/SPA-Q & Phoenix & & 01 & 04 & 01 & 01 & 99 & 99 & MAM \\
\hline 350 & Portable Micro " $R$ " Meter - ASP- I/SPA-B & Phoentx & & 02 & $\infty$ & 08 & 34 & 99 & 99 & MAM \\
\hline 350 & Portabia Micro " $R$ " Meler - ASP-1/SPA-B & Phoenix & & 02 & 05 & 01 & 01 & 99 & 99 & MAM \\
\hline 351 & Portable Neutron rem Counter-ASP-1/NRD & Phoenix & & 01 & $\infty$ & 08 & 34 & 89 & 89 & MAM \\
\hline 351 & Portsblo Noutron rem Counter- ASP-1 1NRD & Phoenix & & 01 & 01 & 01 & 01 & 99 & 99 & MAM \\
\hline 351 & Portable Neutron sem Counter- ASP-1NNRD & Phoenix & & 01 & 02 & 01 & 09 & 99 & 99 & MAM \\
\hline
\end{tabular}




\begin{tabular}{|c|c|}
\hline Toch ' & Technology Tillo \\
\hline 351 & Portablo Neutron rem Counter-ASP.1/NRD \\
\hline 351 & Portablo Neutron rem Counler-ASP-1/NRD \\
\hline 351 & Portable Neutran rem Counter-ASP-1/NRD \\
\hline 351 & Partable Noutron rem Counter-ASP-1/NRD \\
\hline 351 & Portablo Noutron rom Counler-ASP.1/NRD \\
\hline 352 & Porable Photomoter - TDA.2G \\
\hline 352 & Portable Photometer - TDA-2G \\
\hline 352 & Portable Photometer - TDA-2G \\
\hline 352 & Portable Photomoler • TDA.2G \\
\hline 352 & Porabla Pholometor - TDA-2G \\
\hline 352 & Portablo Pholomeler - TDA-2G \\
\hline 352 & Portablo Photomeler - TDA-2G \\
\hline 352 & Portable Photometer - TDA-2G \\
\hline 353 & Porlabla Ventlation Syslem - NARED \\
\hline 354 & Power Shovol \\
\hline 355 & Radiation Monitor- RM-14S \\
\hline 355 & Radiation Monitor. RM-14S \\
\hline 355 & Radiation Monitor- RM-14S \\
\hline 355 & Radialion Monitor. RM-14S \\
\hline 355 & Radiation Monitor- RM-14S \\
\hline 355 & Radiation Monitor- $9 M-14 S$ \\
\hline 355 & Radiation Monitor- RM.14S \\
\hline 355 & Radiation Monitor- RM-14S \\
\hline 356 & Radralion Monitor- RM-20 \\
\hline 358 & Radiation Monitor. RM-20 \\
\hline 358 & Radiation Monitor- RM. 20 \\
\hline 358 & Radiation Monttor- RM-20 \\
\hline & Radiation Monitor- RM-20 \\
\hline 356 & Radration Monitor- RM-20 \\
\hline 358 & Radiation Monitor- RM-20 \\
\hline 356 & Radiation Monitor- RM.20 \\
\hline 357 & Radration Monitor- RM-21 \\
\hline 357 & Radiation Monitor- RM.21 \\
\hline 357 & Radiation Monitor- RM-21 \\
\hline 357 & Radiation Monitor- RM-21 \\
\hline 357 & Radiation Monitor- RM.21 \\
\hline 357 & Radiation Monitor- RM-21 \\
\hline 357 & Radiation Monitor- RM-21 \\
\hline 357 & Radiation Monitor- RM-21 \\
\hline 358 & Radon Gas Moler - TN-Rn2000 \\
\hline 358 & Radon Gas Meter - TN.Rn2000 \\
\hline 358 & Radon Gas Meter - IN.Rn2000 \\
\hline 358 & Radon Gas Meler - TN.Rn2000 \\
\hline 358 & Radon Gas Meter - TN-Rn2000 \\
\hline 358 & Radon Gas Meter - TN.Rn2000 \\
\hline 359 & Radon WL Mater - TN.WL-02 \\
\hline 359 & Radon W Meter - TN-M.02 \\
\hline 360 & Reconfigurable In-Tank Mobile Robot \\
\hline 361 & Remote Clean \& Coat System Ior Spent Fuel \\
\hline 381 & Remole Clean \& Coat System for Spent Fuel \\
\hline 362 & Remolo CO-2 Pellet Elasting 5ystem-ROVCO-2 \\
\hline 382 & Remote CO.2 Pellet Blasting System-ROVCO-2 \\
\hline 382 & Remote CO-2 Pellet Blasting System-ROVCo.2 \\
\hline 363 & Remote Decon \& Dismanting Vehicto \\
\hline 363 & Remote Decon \& Dismanting vehicte \\
\hline 384 & Remoto Excavator- Hax-Trak \\
\hline 364 & Remoto Excavalor- Haz-Trak \\
\hline 385 & Remolo Ftoor Scabbler- Moose \\
\hline 368 & Ramoto Internal Pipo Inspe \\
\hline 387 & Remoto Work Platiorm for Tenk Waste f \\
\hline
\end{tabular}

Dats Source Dala Source

(00) 101) Material (02) Procoss (03) Process (04) Condition (05) Condition Categorles
Identintor Types Types Sub-Types Catogorles calegories Entered By Comment

Phoenix

Phoenix

Phoonix

Phoenix

Phoenix

Phoonix

Phoenix

Phoenix

Phoenix
Phoenix

Phoenix

Phoenix

Phoenix

Phoenix

Phoenix

Phoenix

Phoenix

Phoenix

Phoenix

Phoenix

Phoenix

Phoenix

Phoenix

Phoenix

Phoenix

Phoenix

Phoenix

Phoenix
Phoenix

Phoenix

Phoenix

Phoentx

Phoenix

Phoenix

Phoenix
Phoenix

Phoenlx

Phoenix

Phoenix

Phoenlx

Phoenlx

Phoenix

Phoenix

Proenix

$\begin{array}{lll}01 & 02 & 01 \\ 01 & 03 & 01 \\ 01 & 04 & 01 \\ 02 & 00 & 06 \\ 02 & 05 & 01 \\ 01 & 00 & 06 \\ 01 & 01 & 01 \\ 01 & 02 & 01 \\ 01 & 02 & 01 \\ 01 & 03 & 01 \\ 01 & 04 & 01 \\ 02 & 00 & 06 \\ 02 & 05 & 01 \\ 01 & 00 & 06 \\ 02 & 00 & 04 \\ 01 & 00 & 06 \\ 01 & 01 & 01 \\ 01 & 02 & 01 \\ 01 & 02 & 01 \\ 01 & 03 & 01 \\ 01 & 04 & 01 \\ 02 & 00 & 08 \\ 02 & 05 & 01 \\ 01 & 00 & 06 \\ 01 & 01 & 01 \\ 01 & 02 & 01 \\ 01 & 02 & 01 \\ 01 & 03 & 01 \\ 01 & 04 & 01 \\ 02 & 00 & 06 \\ 02 & 05 & 01 \\ 01 & 00 & 06 \\ 01 & 01 & 01 \\ 01 & 02 & 01 \\ 01 & 02 & 01 \\ 01 & 03 & 01 \\ 01 & 04 & 01 \\ 02 & 00 & 08 \\ 02 & 05 & 01 \\ 01 & 00 & 06 \\ 01 & 00 & 01 \\ 02 & 00 & 06 \\ 02 & 05 & 01 \\ 02 & 08 & 01 \\ 02 & 07 & 01 \\ 01 & 00 & 06 \\ 01 & 00 & 01 \\ 01 & 00 & 07 \\ 01 & 01 & 07 \\ 01 & 02 & 07 \\ 01 & 09 & 02 \\ 01 & 01 & 02 \\ 01 & 02 & 02 \\ 01 & 00 & 02 \\ 01 & 00 & 04 \\ 01 & 00 & 07 \\ 02 & 00 & 07 \\ 01 & 01 & 02 \\ 01 & 00 & 07 \\ 02 & 08 & 07 \\ & & \end{array}$

\begin{tabular}{|c|c|c|c|c|}
\hline 01 & 02 & 99 & 99 & MAM \\
\hline 01 & 01 & 99 & 99 & MAM \\
\hline 01 & 01 & 99 & 99 & MAM \\
\hline 08 & 34 & 99 & 99 & MAM \\
\hline 01 & 01 & 99 & 99 & MAM \\
\hline 06 & 34 & 99 & 99 & MAM \\
\hline 01 & 01 & 99 & 89 & MAM \\
\hline 01 & 01 & 99 & 99 & MAM \\
\hline 01 & 02 & 99 & 99 & MAM \\
\hline 01 & 01 & 99 & 99 & MAM \\
\hline 01 & 04 & 89 & 89 & MAM \\
\hline 08 & 34 & 99 & 99 & MAM \\
\hline 01 & 01 & 99 & 99 & MAM \\
\hline 08 & 34 & 99 & 99 & MAM \\
\hline 04 & 99 & 99 & 99 & SJC \\
\hline 08 & 34 & 99 & 99 & MAM \\
\hline 01 & 01 & 99 & 99 & MAM \\
\hline 01 & 01 & 99 & 99 & MAM \\
\hline 01 & 02 & 99 & 99 & MAM \\
\hline 01 & 01 & 99 & 89 & MAM \\
\hline 01 & 01 & 99 & 99 & MAM \\
\hline 06 & 34 & 99 & 99 & MAM \\
\hline 01 & 01 & 99 & 89 & MAM \\
\hline 06 & 34 & 99 & 99 & MAM \\
\hline 01 & 01 & 99 & 99 & MAM \\
\hline 01 & 01 & 99 & 99 & MAM \\
\hline 01 & 02 & 89 & 99 & MAM \\
\hline 01 & 01 & 89 & 99 & MAM \\
\hline 01 & 01 & 99 & 99 & MAM \\
\hline 06 & 34 & 99 & 99 & MAM \\
\hline 01 & 01 & 89 & 99 & MAM \\
\hline$D \theta$ & 34 & 99 & 99 & MAM \\
\hline 01 & 01 & 99 & 99 & MAM \\
\hline 01 & 01 & 99 & 89 & MAM \\
\hline 01 & 02 & 99 & 99 & MAM \\
\hline 01 & 01 & 99 & 99 & MAM \\
\hline 01 & 01 & 99 & 99 & MAM \\
\hline$D B$ & 34 & 99 & 99 & MAM \\
\hline 01 & 01 & 99 & 99 & MAM \\
\hline 06 & 34 & 99 & 99 & MAM \\
\hline 01 & 01 & 99 & 99 & MAM \\
\hline 06 & 34 & 99 & 89 & MAM \\
\hline 01 & 01 & 99 & 99 & MAM \\
\hline 01 & 01 & 99 & 99 & MAM \\
\hline 01 & 01 & 99 & 99 & MAM \\
\hline 06 & 34 & 99 & 99 & MAM \\
\hline 01 & 01 & 99 & 99 & MAM \\
\hline 07 & 04 & 89 & 99 & SUC \\
\hline 07 & 99 & 99 & 99 & SJC \\
\hline 07 & 99 & 99 & 99 & SUC \\
\hline 02 & 07 & 01 & 03 & SJC \\
\hline 02 & 07 & 02 & 03 & SJC \\
\hline 02 & 11 & 05 & 02 & SJC \\
\hline 02 & 99 & 99 & 99 & SJC \\
\hline 04 & 99 & 99 & घ9 & $\mathrm{SJC}$ \\
\hline 07 & 99 & 99 & 99 & SJC \\
\hline 07 & 99 & 99 & 99 & SJC \\
\hline 02 & 07 & 99 & 99 & SUC \\
\hline 07 & 02 & 89 & 99 & SJC \\
\hline 07 & 99 & 99 & 99 & SJC \\
\hline
\end{tabular}




\begin{tabular}{|c|c|c|c|c|c|c|c|c|c|c|}
\hline Tech ID & Technology Titlo & Data Source & $\begin{array}{l}\text { Data Source } \\
\text { Identifier }\end{array}$ & $\begin{array}{l}(00) \\
\text { Decommissioning } \\
\text { Categories }\end{array}$ & $\begin{array}{l}\text { (01) Material } \\
\text { Types }\end{array}$ & $\begin{array}{l}\text { (02) Process } \\
\text { Types }\end{array}$ & $\begin{array}{l}\text { (03) Process } \\
\text { Sub-Types }\end{array}$ & $\begin{array}{l}\text { (04) Condtition } \\
\text { Categories }\end{array}$ & $\begin{array}{l}\text { (05) Condition } \\
\text { Sub- } \\
\text { Categories }\end{array}$ & $\begin{array}{l}\text { Basie Dat: } \\
\text { Entered By }\end{array}$ \\
\hline $\begin{array}{l}367 \\
368\end{array}$ & $\begin{array}{l}\text { Remote Work Plattorn for Tank Waste Retrieval } \\
\text { Remotely Operated Inspection Veticle- MS A } \\
\text { Scout }\end{array}$ & $\begin{array}{l}\text { Phoenix } \\
\text { Phoenix }\end{array}$ & & $\begin{array}{l}02 \\
00\end{array}$ & $\begin{array}{l}07 \\
00\end{array}$ & $\begin{array}{l}07 \\
07\end{array}$ & $\begin{array}{l}99 \\
04\end{array}$ & $\begin{array}{l}99 \\
99\end{array}$ & $\begin{array}{r}99 \\
99\end{array}$ & $\begin{array}{l}\text { SIC } \\
\text { SJC }\end{array}$ \\
\hline 369 & Removing Plutonium trom Wasto Streams & Phoonix & & 02 & 05 & 08 & 39 & 99 & 99 & MAM \\
\hline 369 & Removing Plutonium from Waste Streams & Phoenix & & 02 & 08 & 08 & 39 & 99 & & MAM \\
\hline 369 & Removing Plutonium from Waste Streams & Phoenix & & 02 & 07 & 08 & 39 & 99 & 99 & MAM \\
\hline 370 & $\begin{array}{l}\text { ROBOCON Operator Interface for Robotic } \\
\text { Applications }\end{array}$ & Phoenix & & 01 & 00 & 07 & 99 & 99 & 99 & suc \\
\hline 370 & $\begin{array}{l}\text { ROBOCON Operator Interface for Robotic } \\
\text { Applications }\end{array}$ & Phoonix & & 02 & $\infty$ & 07 & 99 & 99 & 99 & SIC \\
\hline 371 & $\begin{array}{l}\text { Robotic End Enector for Inspection of Storago } \\
\text { Tanks }\end{array}$ & Phoenix & & 01 & 07 & 07 & 99 & 99 & 99 & suc \\
\hline 371 & $\begin{array}{l}\text { Robotic End Elrector for Inspoction of Slorago } \\
\text { Tanks }\end{array}$ & Phoenlx & & 01 & 07 & 07 & 04 & 99 & 99 & suc \\
\hline 372 & $\begin{array}{l}\text { Robolic System to Retrievo Tubos (TRR) } \\
\text { Robotic Sysiom (o Retrieve Tubes (TRR) }\end{array}$ & $\begin{array}{l}\text { Phoenix } \\
\text { Phoonix }\end{array}$ & & $\begin{array}{l}01 \\
01\end{array}$ & $\begin{array}{l}02 \\
02\end{array}$ & $\begin{array}{l}07 \\
07\end{array}$ & $\begin{array}{l}16 \\
18\end{array}$ & $\begin{array}{l}10 \\
10\end{array}$ & $\begin{array}{l}99 \\
99\end{array}$ & $\begin{array}{l}\text { SJC } \\
\text { SJC }\end{array}$ \\
\hline $\begin{array}{l}372 \\
373\end{array}$ & $\begin{array}{l}\text { Robotic Sysiem to Retrieve Tubes (TRR) } \\
\text { Rolary Vane Low Volume Air Sampler- VS23- } \\
\text { o523CV }\end{array}$ & Phoenix & & 01 & 00 & 01 & 01 & 99 & 99 & MAM \\
\hline 373 & $\begin{array}{l}\text { Rotary Vane Low Volume Air Sampler. VS23. } \\
0523 \mathrm{CV}\end{array}$ & Phoenix & & 01 & 00 & DB & 34 & 99 & 99 & MAM \\
\hline 374 & Sampling Equipment-AMS 4130 & Phoenix & & $\infty$ & 00 & 99 & 99 & 99 & 99 & MAM \\
\hline 375 & Sampling Equipment- B.460 00 & Phoenix & & $\infty$ & $\infty$ & 99 & 99 & 99 & 99 & MAM \\
\hline 378 & Scabbler- t.UF & Phoenix & & 01 & 01 & 02 & 07 & 01 & 99 & SJC \\
\hline 376 & Scabbler. 1.UF & Phoenix & & 01 & 01 & 02 & 07 & 02 & 99 & Suc \\
\hline 377 & Scabbler-3.wCD & Phoenix & & 01 & 01 & 02 & 07 & 09 & 99 & SJC \\
\hline 377 & Scabbler. 3.WCD & Phoenix & & 01 & 01 & 02 & 07 & 02 & 99 & suc \\
\hline 378 & Scabbler. CD.5 & Phoenix & & 01 & 01 & 02 & 07 & 01 & 99 & SJC \\
\hline 378 & Scabbler-CD-5 & Phoenix & & 01 & 01 & 02 & 07 & 02 & 99 & SJC \\
\hline 379 & Scabbler- L-5 & Phoenix & & 01 & 01 & 02 & 07 & 01 & 99 & SuC \\
\hline 379 & Scabbler. L-S & Phoenix & & 01 & 01 & 02 & 07 & 02 & 99 & SJC \\
\hline 380 & Scabbler- L-7 & Phoenlx & & 01 & 01 & 02 & 07 & 01 & 99 & \\
\hline 380 & Scabbler- L.7 & Phoenix & & 01 & 01 & 02 & 07 & 02 & 89 & Suc \\
\hline 361 & Scabbler-Squirrel & Phoenix & & 01 & 01 & 02 & or & 09 & 89 & SJC \\
\hline 381 & Scabbler-Squirrel & Phoenix & & 01 & 01 & 02 & 07 & 02 & 99 & suc \\
\hline 381 & Scabbler-Squirrel & Phoenix & & 01 & 01 & 02 & 08 & 99 & 99 & SJC \\
\hline 382 & Scabbler- U.11 & Phoenlx & & 01 & 01 & 02 & 07 & 01 & 89 & ssc \\
\hline 382 & Scabbler. U.11 & Phoenix & & 01 & 01 & 02 & 07 & 02 & 99 & S.JC \\
\hline 383 & Scabbler. U.3 & Phoonix & & 01 & 01 & 02 & 07 & 01 & 89 & SJC \\
\hline 383 & Scabbler. U.3 & Phoenix & & 01 & 01 & 02 & 07 & 02 & 89 & s.sc \\
\hline 384 & Scabblar. U.5 & Phoenix & & 01 & 01 & 02 & 07 & 01 & 99 & Ssc \\
\hline 384 & Scabbler. U.5 & Phoenix & & 01 & 01 & 02 & 07 & 02 & 89 & SJC \\
\hline 385 & Scabbler. U.7 & Phoenix & & 01 & 01 & 02 & 07 & 01 & 89 & SJC \\
\hline 385 & Scabbler. U.7 & Phoenix & & 01 & 01 & 02 & 07 & 02 & 99 & ssc \\
\hline 386 & Scalng Hammers. 151 5199.SH-1 & Phoenlx & & 01 & 01 & 02 & 07 & 99 & 99 & SJC \\
\hline 386 & Scaling Hammers- $151,5199 \cdot$ SH-1 & Phoonix & & 01 & 02 & 02 & 99 & 99 & 99 & SJC \\
\hline 387 & Scaling Hammers- 1995190 -ND SSH-3 & Phoentx & & 01 & 01 & 02 & 07 & 99 & 99 & SJC \\
\hline 387 & Scaling Hammors- 199.5190-HD SSH.3 & Phoenix & & 01 & 02 & 02 & 99 & 99 & 99 & ssc \\
\hline 388 & Scarlying Machine- MPL-5WR & Phoenix & & 01 & 01 & 03 & 15 & 99 & 99 & SJC \\
\hline 389 & Scintillation Probe - SPA-8 & Phoonix & & 01 & 00 & 06 & 34 & 99 & 99 & MAM \\
\hline 389 & Scintilation Probe - SPA.B & Phoenlx & & 02 & 00 & 00 & 34 & 89 & 99 & MAM \\
\hline 390 & $\begin{array}{l}\text { Separation of HTO Using Membranes and Tritium } \\
\text { Membrane Test }\end{array}$ & Phoenix & & 02 & 07 & 08 & 39 & 99 & 99 & MAM \\
\hline 391 & Shot Blaster- Gorn 15013 & Phoenix & & 01 & 01 & 02 & 07 & 01 & 03 & ssc \\
\hline 391 & Shot Blaster- Golf 15013 & Phoenix & & 01 & 02 & 02 & 11 & 05 & 02 & sJc \\
\hline 392 & Shredder-Industrial Model & Phoenix & & 01 & 03 & 05 & 33 & 99 & 99 & MAM \\
\hline 393 & $\begin{array}{l}\text { Shredder-Mobile } \\
\text { Sol }\end{array}$ & Phoenix & & 01 & 01 & 05 & 33 & 99 & 99 & MAM \\
\hline 393 & Shredder. Mobilo & Phoenix & & 01 & 02 & 05 & 33 & 99 & 99 & MAM \\
\hline 393 & Shrodder. Mobilo & Phoonix & & 01 & $\infty$ & 05 & 33 & 99 & 89 & MAM \\
\hline & Smart Portablor. ESP-1 & Phoonix & & 01 & $\infty$ & $\infty$ & 34 & 89 & 99 & MAM \\
\hline $\begin{array}{l}394 \\
394\end{array}-12$ & Smart Portublo ESP-1 & Phoenix & & 01 & 01 & 01 & 01 & 89 & 99 & MAM \\
\hline
\end{tabular}




\begin{tabular}{|c|c|c|c|c|c|c|c|c|c|c|}
\hline Teen 10 & Technology TIllo & Data Soureo & $\begin{array}{l}\text { Oata Source } \\
\text { Identlier }\end{array}$ & $\begin{array}{c}(00) \\
\text { Oecommissioning } \\
\text { Calegortes }\end{array}$ & $\begin{array}{l}\text { (01) Matorial } \\
\text { Types }\end{array}$ & $\begin{array}{l}\text { (02) Process } \\
\text { Typas }\end{array}$ & $\begin{array}{l}\text { 103) Procoss } \\
\text { Sub-Typos }\end{array}$ & $\begin{array}{l}\text { (04) Conditlon } \\
\text { Calegorles }\end{array}$ & $\begin{array}{l}\text { (05) Condillon } \\
\text { Sub- } \\
\text { Calegorles }\end{array}$ & $\begin{array}{l}\text { Basic Dat } \\
\text { Entered B }\end{array}$ \\
\hline 394 & Smart Portable. ESP.1 & Phoenix & & 01 & 02 & 01 & 01 & 99 & 99 & MAM \\
\hline 394 & Smart Portable. ESP-1 & Phoenix & & 01 & 02 & 01 & 02 & 99 & 99 & MAM \\
\hline 394 & Smart Portable. ESP-1 & Phoenix & & 01 & 03 & 01 & 01 & 99 & 99 & MAM \\
\hline 394 & Smart Portable. ESP-1 & Phoenix & & 01 & 04 & 01 & 01 & 99 & 99 & MAM \\
\hline 394 & Smart Portable. ESP.1 & Phoenlx & & 02 & 00 & $\infty$ & 34 & 99 & 99 & MAM \\
\hline 394 & Smart Portablo. ESP.1 & Phoenix & & 02 & 05 & 01 & 01 & 99 & 99 & MAM \\
\hline 395 & Smart Portablo- ESP-2 & Phoenix & & 01 & 00 & 08 & 34 & 99 & 99 & MAM \\
\hline 395 & Smart Portablo- ESP.2 & Phoenix & & 01 & 01 & 01 & 01 & 99 & 99 & MAM \\
\hline 395 & ' Smart Portabla- ESP-2 & Phoenly & & 01 & 02 & 01 & 01 & 99 & 99 & MAM \\
\hline 395 & Smart Portablo- ESP.2 & Phoenix & & 01 & 02 & 01 & 02 & 99 & 99 & MAM \\
\hline 395 & Sman Portablo- ESP-2 & Phoenlx & & 01 & 03 & 01 & 01 & 99 & 99 & MAM \\
\hline 395 & Smart Ponablo. ESP-2 & Phoenix & & 01 & 04 & 01 & 01 & 99 & 99 & MAM \\
\hline 395 & Smart Portable. ESP.2 & Phoenlx & & 02 & $\infty$ & 08 & 34 & 99 & 99 & MAM \\
\hline 395 & Smart Portablo- ESP.2 & Phoenlx & & 02 & 05 & 01 & 01 & 99 & 99 & MAM \\
\hline 398 & Son Modia and Blast Equipment & Phoenix & & 01 & 01 & 02 & 07 & 99 & 03 & suc \\
\hline 390 & & Phoenix & & $0 t$ & 01 & 02 & 08 & 99 & 03 & SJC \\
\hline 396 & Son Medla and Blast Equipment & Phoonix & & 01 & 02 & 02 & 10 & 03 & 99 & S.JC \\
\hline 396 & Soft Media and Blasl Equipment & Phoenix & & 01 & 02 & 02 & 11 & 05 & 02 & Suc \\
\hline 396 & Son Media and Blast Equipment & Phoonix & & 01 & 02 & 02 & 11 & 08 & 02 & SJG \\
\hline 397 & Sponge-Jet Surface Prep \& Cleaning System & Phoenix & & 01 & 01 & 02 & 07 & 99 & 03 & S.JC \\
\hline 397 & Sponge-Jel Surface Prep \& Cleaning System & Phoonix & & 01 & 01 & 02 & 08 & 99 & 03 & SJC \\
\hline 397 & Spongo.Jel Surface Prep \& Cleaning System & Phoenix & & 01 & 02 & 02 & 10 & 03 & 99 & SIC \\
\hline 397 & Sponge-Jel Surlace Prep \& Cleaning System & Phoenix & & 01 & 02 & 02 & 11 & 05 & 02 & SJC \\
\hline 397 & Sponge.Jet Surface Prep \& Cleaning System & Phoenix & & 01 & 02 & 02 & 11 & 06 & 02 & SJC \\
\hline 398 & Sprung Instant Shelters & Phoenix & & 01 & 00 & $\infty$ & 38 & 99 & 99 & MAM \\
\hline 399 & Strippable Coating Removal & Phoenix & & 01 & 01 & 02 & 07 & 01 & 03 & SJC \\
\hline 399 & Strippable Coating Removal & Phoonix & & 01 & 01 & 02 & 07 & 02 & 03 & SIC \\
\hline 399 & Strippable Costing Removal & Phoenix & & 01 & 01 & 02 & 08 & 01 & 03 & SJC \\
\hline 399 & Strippable Coating Removal & Phoenix & & 01 & 01 & 02 & 08 & 02 & 03 & SIC \\
\hline 399 & Strippable Coating Removal & Phoonix & & 01 & 02 & 02 & 99 & 99 & 89 & SJc \\
\hline 400 & Tank Wasto Retriavalisurface Decon & Phoonix & & 01 & 02 & 02 & 12 & 07 & 99 & SJC \\
\hline 400 & Tank Waste RetrievauSurface Decon & Phoenix & & 01 & 02 & 02 & 12 & OQ & 99 & S.JC \\
\hline 400 & Tank Waste RetrievauSurface Decon & Phoenix & & 01 & 02 & 02 & 12 & 99 & 99 & Ssc \\
\hline 401 & Tractor w/Backioo aloader & Phoenix & & 02 & $\infty$ & 04 & 99 & 的 & 89 & SJC \\
\hline 402 & Trash Pump & Phoenix & & 02 & 07 & 02 & 99 & 99 & 99 & SJC \\
\hline 403 & Tritium Contamination Monitor $\cdot 05.667$ & Phoenix & & 01 & 00 & 06 & 34 & 99 & 99 & MAM \\
\hline 403 & Tritum Contamination Monitor - 05.667 & Phoenix & & 01 & 01 & 01 & 01 & 99 & 89 & MAM \\
\hline 403 & Trilium Contamination Monitor . 05-667 & Phoenix & & 01 & 02 & 01 & 01 & 89 & 99 & MAM \\
\hline 403 & Tritium Contamination Monitor - 05.667 & Phoenix & & 01 & 02 & 01 & 02 & 89 & 99 & MAM \\
\hline 403 & Tritium Contamination Monitor - 05.667 & Phoonix & & 01 & 03 & 01 & 01 & 99 & 99 & MAM \\
\hline 403 & Tntium Conlamination Monitor - 05-667 & Phoenix & & 01 & 04 & 01 & 01 & 89 & 99 & MAM \\
\hline 403 & Tntium Contamination Montor - 05-667 & Phoenix & & 02 & 00 & $\infty$ & 34 & 99 & 99 & MAM \\
\hline 403 & Tritium Contamination Monitor - 05-687 & Phoenix & & 02 & 05 & 01 & 01 & 99 & 99 & MAM \\
\hline 404 & TRUClean Soil Decon System - TRUClean & Phoenix & & 02 & 05 & 08 & 39 & 99 & 89 & MAM \\
\hline 404 & TRUdiean Soil Decon System - TRUdiean & Phoenix & & 02 & 08 & 08 & 39 & 89 & 99 & MAM \\
\hline 405 & Tru-Motion Manipulator-Model 6 TM-2442 & Phoenix & & 01 & $\infty$ & 07 & 89 & 99 & 99 & SJC \\
\hline 405 & Tru-Motion Manipulalor-Model 6 TM-2442 & Phoenix & & 02 & $\infty$ & 07 & 89 & 99 & 89 & Suc \\
\hline 408 & $\begin{array}{l}\text { Underwater Remole Video Inspection System- } E \text {. } \\
\text { ROV }\end{array}$ & Phoenix & & 01 & $\infty$ & 07 & 04 & 99 & 99 & SJC \\
\hline 407 & Vac-Pac HEPA Vacuum-Model-9 Air Powered & Phoenix & & 01 & 01 & 02 & 07 & 01 & 03 & ssc \\
\hline 408 & Vacuum Blast System-ABB U1-CP & Phoenix & & 01 & 01 & 02 & 07 & 01 & 03 & SJC \\
\hline 409 & Vacuum Blaster- dekleyn dks 71116 & Pthoenix & & 01 & 01 & 02 & 07 & 01 & 03 & suc \\
\hline 409 & Vacuum Blaster. dekleyn dks 7118 & Phoenix & & 01 & 02 & 02 & 11 & 05 & 02 & SJC \\
\hline 409 & Vacuum Blaster- dekleyn dks 7118 & Phoenix & & 01 & 02 & 02 & 11 & 06 & 02 & SJC \\
\hline 410 & Vacurum Elaster. P. $08-2$ & Phoenix & & 01 & 01 & 02 & 07 & 01 & 03 & suc \\
\hline 410 & Vacuum Blaster- P.06-2 & Phoenix & & 01 & 02 & 02 & 11 & 05 & 02 & Suc \\
\hline 110 & Vacuum Elaster. P.06-2 & Phoe & & 01 & 02 & 02 & 11 & 06 & 02 & Suc \\
\hline$\$ 11$ & Vacoum Blaster. P. $00-2$ & Phoenix & & 01 & 01 & 02 & 07 & 01 & 03 & Suc \\
\hline 111 & Vacurm Blaster. P. 08-2 & Phoenix & & 01 & 02 & 02 & 11 & 05 & 02 & Suc \\
\hline 411 & Vacuum Blaster- P.08-2 & Phoenix & & 01 & 02 & 02 & 11 & $\infty 6$ & 02 & SJC \\
\hline
\end{tabular}




\begin{tabular}{|c|c|c|c|c|c|c|c|c|c|c|}
\hline Tech ID & Technology Title & Data Soureo & $\begin{array}{l}\text { Data Source } \\
\text { Identifier }\end{array}$ & $\begin{array}{c}(00) \\
\text { Decommisstoning } \\
\text { Categories }\end{array}$ & $\begin{array}{l}\text { (01) Materlal } \\
\text { Types }\end{array}$ & $\begin{array}{l}\text { (02) Process } \\
\text { Types }\end{array}$ & $\begin{array}{l}\text { (03) Process } \\
\text { Sub-Types }\end{array}$ & $\begin{array}{l}\text { (04) Condition } \\
\text { Categorites }\end{array}$ & $\begin{array}{l}\text { (05) Condition } \\
\text { Sub- } \\
\text { Calegories }\end{array}$ & $\begin{array}{l}\text { Basic Data } \\
\text { Entered By }\end{array}$ \\
\hline 412 & Vacuum Blaster. PB.05U & Phoenix & & 01 & 01 & 02 & 07 & 01 & 03 & suc \\
\hline 412 & Vacuum Blaster-PB-05U & Phoenix & & 01 & 02 & 02 & 11 & 05 & 02 & suc \\
\hline 412 & Vacuum Blaster. PB-0sU & Phoenix & & 01 & 02 & 02 & 11 & 06 & 02 & SIC \\
\hline 413 & Vacuum Blaster-S.04 & Phoonix & & 01 & 01 & 02 & 07 & 01 & 03 & suc \\
\hline 413 & Vacurum Blaster- S.04 & Phoenix & & 01 & 02 & 02 & 11 & 05 & 02 & SIC \\
\hline 413 & Vacuum Elaster- S-04 & Phoenix & & 09 & 02 & 02 & 11 & 06 & 02 & SuC \\
\hline 414 & Vacrum Blaster. SB-03 & Phoenix & & 01 & 01 & 02 & 07 & 01 & 03 & SuC \\
\hline 414 & Vacuum Blaster-SB-03 & Phoenix & & 01 & 02 & 02 & 11 & 05 & 02 & SIC \\
\hline 414 & Vacuum Blaster. SB. 03 & Phoenix & & 01 & 02 & 02 & 11 & 06 & 02 & Suc \\
\hline 415 & Vacuum Blaster- $\mathrm{SHO3}$ & Phoenix & & or & 01 & 02 & 07 & 01 & 03 & SJC \\
\hline 415 & Vacuum Blaster. SHO3 & Phoonix & & 01 & 02 & 02 & 11 & 05 & 02 & suc \\
\hline 415 & Vecuum Blaster-SHO3 & Phoenix & & 01 & 02 & 02 & 11 & 08 & 02 & Suc \\
\hline 418 & $\begin{array}{l}\text { Vehiclo Monitor-Remolo w/2 Pylon Delectors. } \\
\text { 501A-5RP }\end{array}$ & Phoenix & & 00 & $\infty$ & 99 & 99 & 99 & 99 & MAM \\
\hline 417 & Ventilation Unit- MAC-21 PIN FM37 & Phoenix & & 01 & $\infty$ & $0 \theta$ & 34 & 99 & 99 & MAM \\
\hline 418 & Ventlation Unit- PFX-1400A & Phoenix & & 01 & 00 & 08 & 34 & 99 & 99 & MAM \\
\hline 419 & Ventitation Unit- Portaire Model- $1 / 8$ & Phoenix & & 01 & 00 & 08 & 34 & 99 & 99 & MAM \\
\hline 420 & Waste Compactors-MPC-60 & Phoenix & & 02 & 00 & 05 & 33 & 99 & 99 & MAM \\
\hline 420 & Waste Compactors-MPC-60 & Phoenix & & 02 & 05 & 05 & 33 & 99 & 99 & MAM \\
\hline 421 & Water Solublo Polymers for Actinide Removal & Phoenix & & 00 & 00 & 99 & 89 & 99 & 89 & MAM \\
\hline 422 & Wire Saw-BBC-40 & Phoenix & & 01 & 01 & 03 & 89 & 99 & 99 & SJC \\
\hline 422 & Wire Saw-BBC-40 & Phoenix & & 01 & 02 & 03 & 99 & 10 & 89 & SJC \\
\hline 423 & Passive Aerosol Generator & F-LSDP-A & & 01 & 01 & 02 & 07 & 01 & 99 & MAM \\
\hline 423 & Passive Aerosol Generalor & F-LSOP.A & & of & 01 & 02 & 07 & 02 & 99 & MAM \\
\hline 423 & Passive Aerosol Generalor & F.LSDP.A & & 01 & 01 & 02 & 08 & 01 & 99 & MAM \\
\hline 423 & Passive Aerosol Generalor & F.LSDP.A & & 01 & 01 & 02 & 08 & 02 & 99 & MAM \\
\hline 423 & Passivo Aerosol Generator & F.LSOP.A & & 01 & 02 & 02 & 10 & 03 & 99 & MAM \\
\hline 423 & Passive Aerosol Generator & F-LSDP.A & & 01 & 02 & 02 & 10 & 04 & 99 & MAM \\
\hline 423 & Passive Aerosol Generator & F.LSDP.A & & 01 & 00 & 00 & 34 & 99 & 99 & MAM \\
\hline 424 & Brokk BM250 & F-LSDP.A & & 01 & 02 & 03 & 10 & 10 & 99 & MAM \\
\hline 424 & Brokk BM250 & F-LSDP.A & & 01 & 02 & 03 & 18 & 10 & 99 & MAM \\
\hline 424 & Brokk BM250 & F.LSDP.A & & of & 02 & 07 & 89 & 99 & 99 & MAM \\
\hline 424 & Brokk BM250 & F.LSDP-A & & or & 00 & 07 & 99 & O9 & B9 & MAM \\
\hline 425 & Hydraulic Cutting Devico & F.LSDP.A & & 01 & 02 & 03 & 99 & 10 & 99 & MAM \\
\hline 425 & Hydraulic Cutting Device & F.LSDP.A & & 01 & 02 & 07 & 99 & 89 & 99 & MAM \\
\hline 425 & Hydraulic Cutting Device & F.LSDP.A & & 01 & 00 & 07 & 99 & 99 & 99 & MAM \\
\hline 426 & Transite "Boll" Removal and Capture Device & F-LSDP-A & & 01 & 02 & 03 & 99 & 10 & 99 & MAM \\
\hline 428 & Transito "Boll" Removal and Capture Device & F.LSDP.A & & 01 & 02 & 07 & 99 & 99 & 99 & MAM \\
\hline 426 & Transito "Boll" Removal and Cupture Device & F.LSDP.A & & of & 00 & 07 & 99 & 89 & 89 & MAM \\
\hline$\$ 27$ & Remotely Operated Mobilo Worksystem & F.LSDP.A & & 01 & $\infty$ & 07 & $9 \theta$ & 99 & 99 & MAM \\
\hline 428 & USRADS (soil characterization) & F.LSDP.A & & 01 & 00 & 01 & 01 & 13 & 89 & MAM \\
\hline 429 & Pneu-worm (REMOTEC Robols) & F.LSDP.R & & 01 & 02 & 01 & 02 & 11 & 99 & MAM \\
\hline 429 & Pneu-worm (REMOTEC Robots) & F-LSDP-R & & 01 & 02 & 01 & 02 & 12 & 99 & MAM \\
\hline 429 & Pnou-wom (REMOTEC Robots) & F.LSDP.R & & 01 & $\infty$ & 07 & 99 & 99 & 99 & MAM \\
\hline 430 & Infrared Spectroscopy & F.LSDP.R & & 01 & $\infty$ & 01 & 99 & 89 & 99 & MAM \\
\hline 431 & ANDROS Hazardous duty mobile robots & F.LSDP.R & & 01 & $\infty$ & 07 & 99 & 89 & 99 & MAM \\
\hline 432 & Wavelength Dispersive $X$.ray Spectroscopy & F-LSDP.R & & 01 & $\infty$ & 01 & 99 & 99 & 99 & MAM \\
\hline 433 & Telerobolic System & F.LSDP.R & & 01 & $\infty$ & 07 & 99 & 89 & 99 & MAM \\
\hline 434 & $\begin{array}{l}\text { Remolely Controlledmobire Cutting \& Supporting } \\
\text { Unit }\end{array}$ & F.LSDP.R & & 01 & $\infty$ & 07 & 99 & 89 & 89 & MAM \\
\hline 434 & $\begin{array}{l}\text { Remotely ControlledMobile Cutting \& Supportung } \\
\text { Unit }\end{array}$ & F.LSDP.R & & 01 & 02 & 01 & 02 & 89 & 99 & MAM \\
\hline 435 & Supplied Air Containment & F.LSDP.R & & 01 & $\infty$ & 06 & 38 & 99 & 99 & MAM \\
\hline 438 & $\begin{array}{l}\text { DECOHA Process Chemical Decontamination of } \\
\text { Metal }\end{array}$ & F.LSDP.R & & 01 & 02 & 02 & 10 & 99 & 99 & MAM \\
\hline 436 & $\begin{array}{l}\text { DECOHA Process Chemical Decontamination of } \\
\text { Metal }\end{array}$ & F.LSDP.R & & 01 & 02 & 02 & 12 & 99 & 99 & MAM \\
\hline 437 & Actosol & F-LSDP.R & & 01 & 02 & 02 & 99 & 99 & 89 & MAM \\
\hline 438 & KSI Tentado Manipulator & F-LSDP-R & & 01 & $\infty$ & 07 & 99 & 89 & 99 & MAM \\
\hline 439 & PO'WWER Aqueous Waste Treatment & F-LSDP.R & & 02 & 07 & OB & 37 & 99 & 99 & MAM \\
\hline
\end{tabular}




\begin{tabular}{|c|c|c|c|c|c|c|c|c|c|c|}
\hline Tech IT & Technology Tillo & Data Source & $\begin{array}{l}\text { Data Source } \\
\text { Idontifier }\end{array}$ & $\begin{array}{c}(00) \\
\text { Decommissioning } \\
\text { Categories }\end{array}$ & $\begin{array}{l}\text { (01) Material } \\
\text { Types }\end{array}$ & $\begin{array}{l}\text { (02) Process } \\
\text { Typos }\end{array}$ & $\begin{array}{l}\text { (03) Process } \\
\text { Sub-Types }\end{array}$ & $\begin{array}{l}\text { (04) Condition } \\
\text { Categorles }\end{array}$ & $\begin{array}{l}\text { (05) Condition } \\
\text { Sub- } \\
\text { Categories }\end{array}$ & $\begin{array}{l}\text { Baslc Duth } \\
\text { Entered By }\end{array}$ \\
\hline 439 & PO'WWER Aqueous Wasto Treatment & F.LSDP.R & & 02 & 07 & 08 & 38 & 99 & 99 & MAM \\
\hline 440 & Airtight Modular Workshop & F.LSDP.R & & 01 & 00 & 06 & 34 & 99 & 99 & MAM \\
\hline 440 & Airtight Modular Workshop & F-LSOP.R & & 01 & 00 & 08 & 36 & 99 & 99 & MAM \\
\hline 441 & Plasma Arc Cutting Undenwater & F.LSOP.R & & 01 & 02 & 03 & 99 & 99 & 99 & MAM \\
\hline 442 & Laser Photoacoustic Spoctroscopy & F.LSDP-R & & 01 & 00 & 01 & 99 & 89 & 99 & MAM \\
\hline 443 & Plasma Arc Fixed Hoanth Fumaco & TMS & 26 & 02 & 05 & 00 & 40 & 99 & 99 & MAM \\
\hline 443 & Plasma ArC Fixod. Hoarth Fumace & TMS & 28 & 02 & 05 & 08 & 41 & 99 & 99 & MAM \\
\hline 443 & Plasma Are Fixed-Hoarth Fumaco & TMS & 28 & 01 & 00 & 05 & 33 & 99 & 99 & MAM \\
\hline 444 & - Vortec Combustion Meller System & TMS & 68 & 02 & 05 & 00 & 40 & 99 & 99 & MAM \\
\hline 444 & Vorree Combustion Mether System & TMS & 68 & 02 & 05 & 08 & 41 & 99 & 99 & MAM \\
\hline 444 & Vortec Combuston Melter System & TMS & 68 & 01 & 00 & 05 & 33 & 99 & 99 & MAM \\
\hline 445 & $\begin{array}{l}\text { Gas Phase Docontamination Procoss for Gaseous } \\
\text { Diffusion Equipment }\end{array}$ & TMS & 88 & 01 & 02 & 02 & 12 & 99 & 89 & MAM \\
\hline 445 & $\begin{array}{l}\text { Gas Phase Decontamination Procoss for Gaseous } \\
\text { Diffusion Equipment }\end{array}$ & TMS & 88 & 01 & 02 & 02 & 10 & 99 & 99 & MAM \\
\hline 446 & Catalytic Chemical Oxidation (Delphi Delox) & TMS & 108 & 01 & $\mathbf{0 0}$ & 08 & 37 & 99 & 99 & MAM \\
\hline 446 & Catalyic Chemical Oxidation (Dolphi Detox) & TMS & 108 & 02 & 07 & 08 & 37 & 99 & 99 & MAM \\
\hline 447 & Low Temperature Thermal Desoption (Vac Trax) & TMS & 107 & 01 & 00 & 08 & 37 & 99 & 99 & MAM \\
\hline 447 & Low Temperature Thermal Desorption (Vac Trax) & TMS & 107 & 02 & 05 & 08 & 37 & 99 & 99 & MAM \\
\hline 448 & Wasto Inspection Tomography (min) & TMS & 259 & 01 & 00 & 01 & 03 & 13 & 99 & MAM \\
\hline 449 & Intelligent Inspection and Survoy Robot & TMS & 272 & 01 & 00 & 07 & 89 & 99 & 99 & MAM \\
\hline 449 & Intelligent Inspection and Survoy Robot & TMS & 272 & 01 & $\infty 0$ & 01 & 03 & 99 & 99 & MAM \\
\hline 450 & Mult-Analyte. Single Fiber Optical Sensor & TMS & 383 & 01 & $\infty$ & 07 & 99 & 99 & 99 & MAM \\
\hline 450 & Multr-Analyto, Singlo Fiber Optical Sensor & TMS & 383 & 01 & $\infty$ & 01 & 99 & 99 & 99 & MAM \\
\hline 451 & Associaled Particle Imaging Development & TMS & 413 & 01 & 00 & 01 & 03 & 13 & 99 & MAM \\
\hline 452 & $\begin{array}{l}\text { Tooling Systoms for Massive Equipment Size } \\
\text { Reduction and Removal }\end{array}$ & TMS & 1462 & 01 & 00 & 07 & 99 & 89 & 99 & MAM \\
\hline 452 & $\begin{array}{l}\text { Tooling Systems for Massive Equipment Size } \\
\text { Reduction and Removal }\end{array}$ & TMS & 1482 & 01 & 02 & 03 & 98 & 99 & 99 & MAM \\
\hline 453 & 3.0 Mapping System & 105.C ISSP & & 01 & 01 & 01 & 99 & 89 & 99 & suc \\
\hline 453 & 3.0 Mapping System & 105-C ISSP & · & 01 & 02 & 01 & 99 & 89 & 99 & SJC \\
\hline 453 & 3.0 Mapping System & 105-C ISSP & & 01 & 03 & 09 & 89 & 99 & 99 & ssc \\
\hline 454 & Automalic Conveyor Montor & 105.C ISSP & & 02 & 05 & 08 & 99 & 99 & 99 & SIC \\
\hline 455 & Box and Container Counter System & 105.C ISSP & & 02 & 05 & 08 & 99 & 89 & 99 & SJC \\
\hline 455 & Box and Container Counter System & 105-C ISSP & & 02 & 08 & 08 & 99 & 89 & 89 & suc \\
\hline 455 & Box and Container Counter System & 105-C ISSP & & 02 & 07 & 08 & 89 & 89 & 99 & SJC \\
\hline 456 & $\begin{array}{l}\text { Field.Ponable Energy Dispersive X.Ray } \\
\text { Fluorescence Analytical Instrument with Increased } \\
\text { Sensitivity }\end{array}$ & 105-C ISSP & & 01 & $\infty$ & 01 & 89 & 89 & 99 & suc \\
\hline 457 & Gamma Spectroscopy & 105.C ISSP & & 02 & 05 & 08 & 99 & 99 & 99 & \\
\hline 457 & Gamma Spectroscopy & 105.C ISSP & & 02 & 08 & 08 & 99 & 89 & 99 & ssc \\
\hline 457 & Gamma Spectroscopy & 105-C ISSP & & 02 & 07 & 08 & 99 & 89 & 99 & Suc \\
\hline 458 & Imaging Nuclear Survey Instrumentation & 105.C ISSP & & 01 & $\infty 0$ & 01 & 99 & 89 & 99 & SUC \\
\hline 459 & In-Situ Gamma Spectroscopy Counting System & 105-C ISSP & & 01 & 00 & 01 & 01 & 89 & 99 & suc \\
\hline 460 & JO3 Drum Counling System & 105-C ISSP & . & 02 & 00 & 08 & 99 & 89 & 99 & suc \\
\hline 461 & Chemical Decontamination with Recyclo & 105-C ISSP & & 01 & $\infty$ & 02 & 99 & 99 & 99 & suc \\
\hline 462 & Laser Ablation Decontamination & 105-C ISSP & & 01 & $\infty$ & 02 & 99 & 89 & 99 & SJC \\
\hline 463 & Laser Based Coaling Removal System & 105-C ISSP & & 01 & $\infty$ & 02 & 99 & 89 & 99 & SJC \\
\hline 464 & Laser Surface Decontamination & 105-C ISSP & & 01 & $\infty$ & 02 & 99 & 99 & 99 & suc \\
\hline 485 & Liquid Abrasive Blast Cleaning & 105-C ISSP & & 01 & 00 & 02 & 99 & 89 & 99 & suc \\
\hline 468 & Strippable Polymer & TOS-C ISSP & & 01 & $\infty$ & 02 & 99 & 99 & 89 & suc \\
\hline 487 & Air Cooled Respirator/Suit & 105-C ISSP & & 01 & 00 & $\infty$ & 36 & 99 & 99 & SJe \\
\hline 468 & Nu Fab Sack Suit & 105-C ISSP & & 01 & $\infty$ & $\infty$ & 36 & 99 & 99 & SJC \\
\hline 469 & Bulk Media Processing & 105.C ISSP & & 02 & 00 & 08 & 99 & 89 & 99 & Suc \\
\hline 470 & Processing ACM for Disposal & 105-C ISSP & & 02 & 04 & 08 & 89 & 89 & 99 & suc \\
\hline 471 & Characterization Data Management Systems & 105.C ISSP & & 01 & $\infty$ & 01 & 99 & 99 & 89 & ssc \\
\hline 472 & $\begin{array}{l}\text { In-Situ Gamma Spectroscopy Counting Systems } \\
\text { for Samplers or Otjects }\end{array}$ & 105-C ISSP & & 01 & $\infty$ & 01 & 99 & 99 & 89 & SJC \\
\hline 473 & $\begin{array}{l}\text { In-Situ Gamma Spectroscopy Counting Systems } \\
\text { for Soils and Surfaces }\end{array}$ & 105-C ISSP & & 01 & $\infty$ & 0 & 99 & 99 & 99 & SJC \\
\hline
\end{tabular}




\begin{tabular}{|c|c|c|c|c|c|c|c|c|c|c|}
\hline Tech ic & Technology THe & Data Source & $\begin{array}{l}\text { Data Source } \\
\text { Identiner }\end{array}$ & $\begin{array}{c}(00) \\
\text { Decommissioning } \\
\text { Categories }\end{array}$ & $\begin{array}{l}\text { (01) Materiat } \\
\text { Types }\end{array}$ & $\begin{array}{l}\text { (02) Process } \\
\text { Types }\end{array}$ & $\begin{array}{l}\text { 103) Process } \\
\text { Sub-Types }\end{array}$ & $\begin{array}{l}\text { 104) Condition } \\
\text { Categories }\end{array}$ & $\begin{array}{l}\text { (05) Condillon } \\
\text { Sub- } \\
\text { Categories }\end{array}$ & $\begin{array}{l}\text { Basle Data } \\
\text { Entored By }\end{array}$ \\
\hline 474 & Waste Sorting/Segregation & 105-C ISSP & & 02 & 05 & 05 & 30 & 99 & 99 & suc \\
\hline 475 & Decontamination Gel & 105-C ISSP & & 01 & 00 & 02 & 99 & 99 & 99 & SJC \\
\hline 476 & Ulirasonic & 105-C ISSP & & 01 & 00 & 02 & 99 & 99 & 99 & suc \\
\hline 477 & Steel Plates and Grout & 105.C ISSP & & 02 & 00 & 08 & 99 & 99 & 99 & SNC \\
\hline 478 & Light Weight Sheating & 105-C ISSP & & 02 & 00 & 08 & 99 & 99 & 99 & ssc \\
\hline 479 & Spray on Encapsulant & 105-C ISSP & & 02 & 00 & 08 & 99 & 99 & 99 & SJC \\
\hline 480 & Bio Surfaco Degradation & Demo Summary & & 01 & $\infty$ & 02 & 99 & 99 & 99 & SJC \\
\hline 481 & LN2 Carrior w/Solid CO2 Partides & Demo Summary & & 01 & 00 & 02 & 99 & $\mathbf{9 9}$ & $\mathbf{9 9}$ & SJC \\
\hline 482 & - Long Rango Alpha Detoctor & Demo Summary & & 01 & 00 & 01 & 99 & 99 & 99 & suc \\
\hline 483 & Mobile Aqueous Bome Ozone Laundry Service & Demo Summary & & 01 & 00 & 06 & 38 & 99 & 99 & SJC \\
\hline 484 & Nomad Facilly Characterization & Demo Summany & & 01 & 00 & 01 & 99 & 99 & 89 & SJC \\
\hline 485 & Nomad Wasto Characterization & Demo Summary & & 02 & $\mathbf{0 0}$ & 08 & 99 & 99 & 99 & SIC \\
\hline 486 & Ofl-site Laundry Servico for Reussble Clothing & Demo Summary & & 01 & 00 & 08 & 38 & 99 & 99 & suc \\
\hline 487 & Photogrammotry & Demo Summary & & 01 & $\infty$ & 01 & 99 & 99 & 89 & SJC \\
\hline 488 & Pipo Walker & Demo Summary & & 01 & 02 & 01 & 02 & 99 & 89 & SJC \\
\hline 489 & Plastic Pelle! Btasting & Doma Summary & & 01 & 00 & 02 & 99 & 99 & 99 & suc \\
\hline 490 & Quk-Solid Superabsorbent Polymer & Domo Summary & & 02 & 07 & 08 & 99 & 99 & 99 & suc \\
\hline 491 & Radscan & Demo Summary & & 01 & 00 & 01 & 99 & 99 & 99 & Suc \\
\hline 492 & Thermat Wear RiteChargo & Demo Summary & & 01 & $\infty$ & $\infty$ & 36 & 99 & 89 & SJC \\
\hline 494 & Water Soluble Polymers for RCRA Wasto Removal & TMS & 1439 & 02 & 00 & 08 & 99 & 89 & 99 & SJC \\
\hline 495 & $\begin{array}{l}\text { Sell-assembled Monolayers on Mesoporous } \\
\text { Supports }\end{array}$ & TMS & 1447 & 02 & 00 & 08 & 99 & 89 & 99 & suc \\
\hline 496 & Mercury Amalgamation and Stablization & TMS & 1630 & 02 & $\infty$ & 08 & 99 & 99 & 99 & suc \\
\hline 497 & Mercury Removal from Solid Mixed Waste & TMS & 1708 & 02 & 05 & 08 & 99 & 99 & 99 & SJC \\
\hline 498 & Rapid Surtace Sampling and Archive Record Sys & TMS & 98 & 01 & 01 & 01 & 01 & 99 & 99 & suc \\
\hline 498 & Rapid Surface Sampling and Archive Record Sys & TMS & 90 & 01 & 02 & 01 & 01 & 99 & 99 & suc \\
\hline 499 & Small Pipo Charactenization Syslem & TMS & 43 & 01 & 02 & 01 & 02 & 99 & 99 & Suc \\
\hline 500 & In Situ Chemical Treatment of Asbestos & TMS & 73 & 02 & 04 & $0 \theta$ & 42 & 99 & 99 & SJC \\
\hline so1 & Intemal Duct Characterization System & TMS & 42 & 01 & 02 & 01 & 02 & 99 & 99 & Suc \\
\hline 502 & $\begin{array}{l}\text { Anion Exchange Resin Development lor } \\
\text { Technitium Removal }\end{array}$ & TMS & 400 & 02 & 07 & 08 & 39 & 99 & 99 & sJc \\
\hline 503 & $\begin{array}{l}\text { Inductively Coupled Plasma-Mass Spectrometry } \\
\text { for Analysis of Microliter Samples and Solids }\end{array}$ & TMS & 133 & 01 & 00 & 01 & 99 & 99 & 89 & sJc \\
\hline 504 & DISPIM (In Situ Pu Invenioy Monitor) & ODS Table 09.1 & & 02 & 05 & 08 & 99 & 99 & 99 & SJC \\
\hline 505 & TRU Piece/Package Monitor & ODS Tablo 09.1 & & 02 & 05 & 08 & 99 & 99 & 99 & S.JC \\
\hline 508 & TRUCHEM decontamination & ODS Table 0.91 & & $0 t$ & 00 & 02 & 98 & 99 & 99 & SIC \\
\hline 507 & Electrolytic Decontamination & ODS Table 09.1 & & 01 & 00 & 02 & 99 & 99 & 89 & SIC \\
\hline 508 & Robotics Sizo Reduetion Facillty & ODS Table 0.8.1 & & 01 & 00 & 03 & 99 & 89 & 99 & s.te \\
\hline 509 & Plasma Are Torch w/Enhaneed Fumo Control & ODS Table $0.8,1$ & & 01 & 02 & 04 & 99 & 99 & 99 & S.JC \\
\hline 510 & Beryllium Swipe Monitor & ODS Table 0.9.1 & & 01 & 01 & 08 & 34 & 99 & 99 & s.JC \\
\hline 510 & Beryllium Swipe Monitor & ODS Table 09.1 & & 01 & 02 & 06 & 34 & 99 & 99 & SJC \\
\hline 511 & ssac Cementation & ODS Table 09.1 & & 02 & 00 & 08 & 99 & 99 & 99 & $S J C$ \\
\hline 512 & Ash Cementation & ODS Tablo 0.81 & . & 02 & 00 & 08 & 99 & 99 & 89 & SJC \\
\hline 513 & Vertical Calciner & ODS Table 0.99 & & 02 & 07 & OB & 33 & 99 & 99 & suc \\
\hline 514 & Roducing grout & ODS Table 0.9.1 & & 02 & $\infty$ & 08 & 99 & $\mathbf{9 9}$ & 99 & SJC \\
\hline 515 & Diamond wire cutting & ODS Table 081 & & 01 & 01 & 03 & 08 & 99 & 89 & SJC \\
\hline 516 & Berytlium Air Monitor & ODS Table 0.9.1 & & 01 & 00 & $\infty 8$ & 34 & 99 & 99 & SJC \\
\hline 517 & Automatic Demolition Dust Suppression System & TMS. ITSR.2154 & 2154 & 01 & 01 & 08 & 34 & 89 & 99 & MAM \\
\hline 518 & Compact Subsurfaco Inve stigation System & TMS & 2153 & 02 & 05 & 01 & 99 & 89 & 99 & MAM \\
\hline 519 & Concrete Diamond Grinder & TMS. ITSR-2102 & 2102 & 01 & 01 & 02 & 07 & 89 & 89 & MAM \\
\hline 519 & Concrelo Diamond Grinder & TMS. ITSR-2102 & 2102 & 01 & 01 & 02 & 08 & 99 & 99 & MAM \\
\hline 520 & Concreto Spaller & TMS. ITSR-2152 & 2152 & 01 & 01 & 02 & 08 & 99 & 99 & MAM \\
\hline 521 & $\begin{array}{l}\text { Liquid-Nitrogen Cooled Diamona-Wire Concrate } \\
\text { Culting }\end{array}$ & TMS & 2107 & 09 & 01 & 03 & 99 & 99 & 89 & MAM \\
\hline 522 & Reactor Stabilizer & TMS, ITSR-1839 & 4839 & 01 & 99 & 06 & 34 & 99 & 99 & MAM \\
\hline 523 & High Pressure Water Cleaning & ITSR.1780 & & 01 & 02 & 02 & 10 & 04 & 89 & MAM \\
\hline 524 & Manual Alphia-Bota (FM-AG) & ITSR.1788 & & 01 & 01 & 01 & 01 & 99 & 99 & MAM \\
\hline 525 & Manual Alpha-Bota (Eloctra NE) & ITSR-1798 & & 01 & 01 & 04 & 01 & 99 & 99 & MAM \\
\hline
\end{tabular}




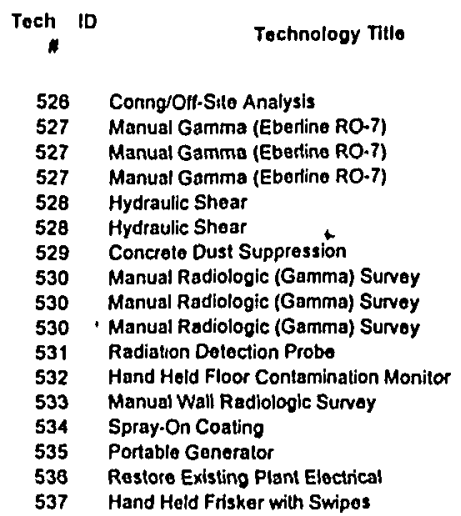

Dala Source ITSR-2098 ITSR-1840
ITSR-1840 ITSR-1840 ITSR-1840 ITSR-1948 ITSR-1948 ITSR.2154
ITSR-1793 ITSR.1793 ITSR-1793 ITSR-1946 ITSR-1942 ITSR-1470 ITSR-1839 ITSR-1795 ITSR-1999

Oata Source (00)

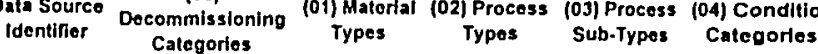

Matcrial (02) Process
Types
Typos Process (04) Condition

(05) Condition

01
01
01
01
01
01
01
01
01
01
01
01
01
01
01
01
01

01
01
02
03
02
02
01
01
02
03
00
01
01
99
00
00
01

a

01
01
01
01
03
03
06
01
01
01
01
01
02
06
08
06
01

$\begin{array}{ll}01 & 99 \\ 01 & 12 \\ 01 & 12 \\ 01 & 12 \\ 17 & 10 \\ 18 & 10 \\ 34 & 99 \\ 01 & 12 \\ 01 & 12 \\ 01 & 12 \\ 01 & 99 \\ 01 & 01 \\ 08 & 01 \\ 34 & 99 \\ 99 & 99 \\ 99 & 99 \\ 01 & 01\end{array}$

99

99 MAM

MAM

MAM

MAM

MAM

MAM

MAM

MAM

MAM

MAM

MAM

MAM

MAM

Hand Held Frisker with Swipos 
APPENDIX

\section{FACILITIES DATABASE STRUCTURI}




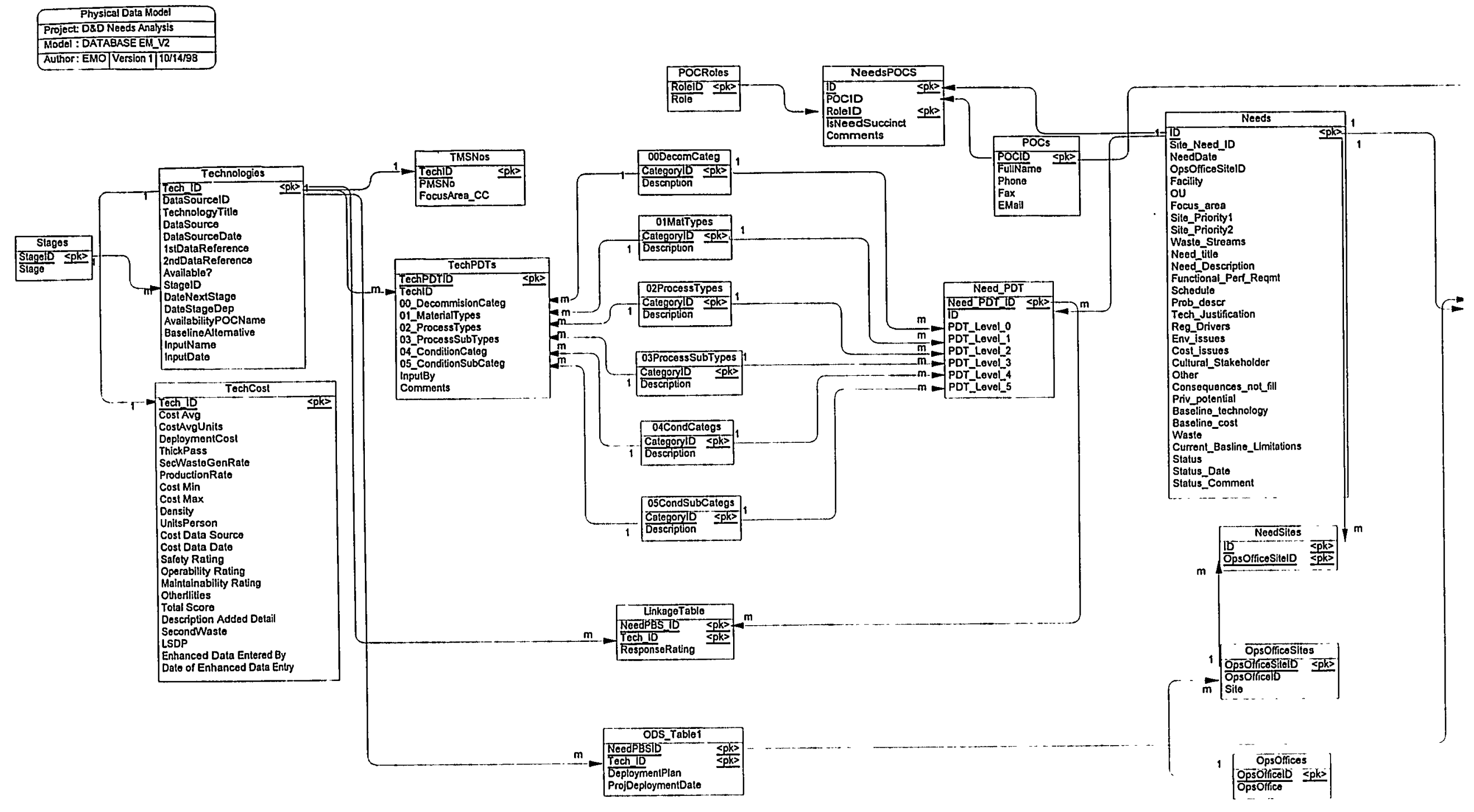



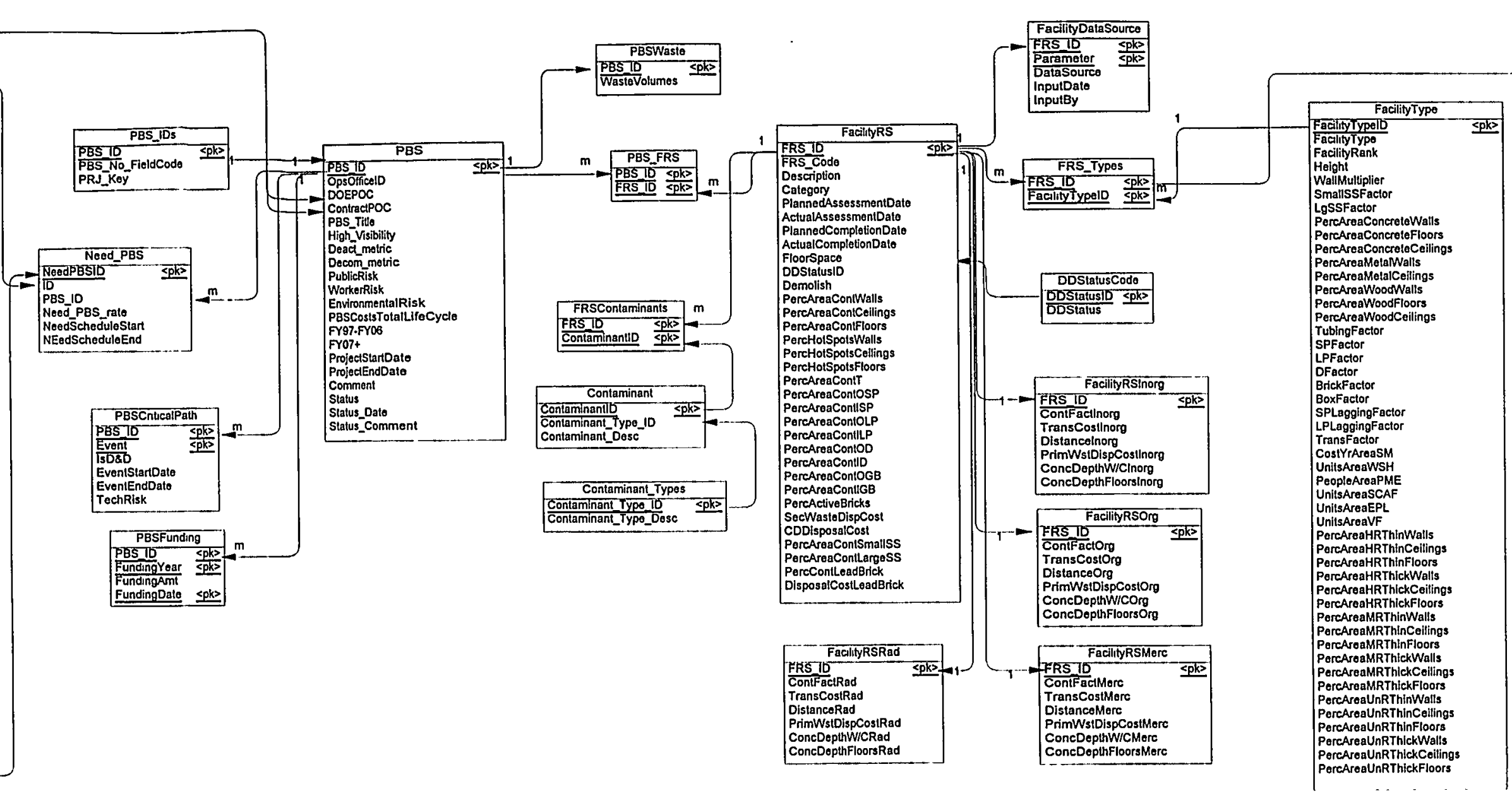


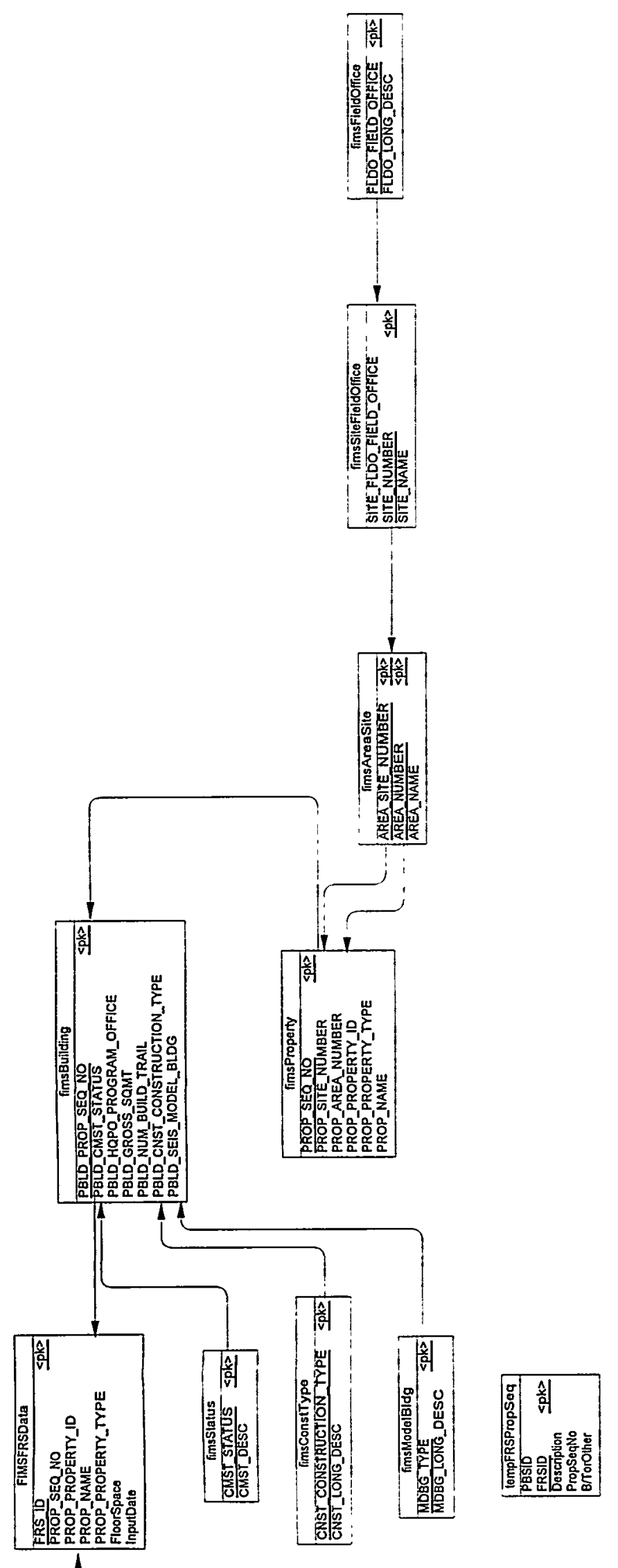



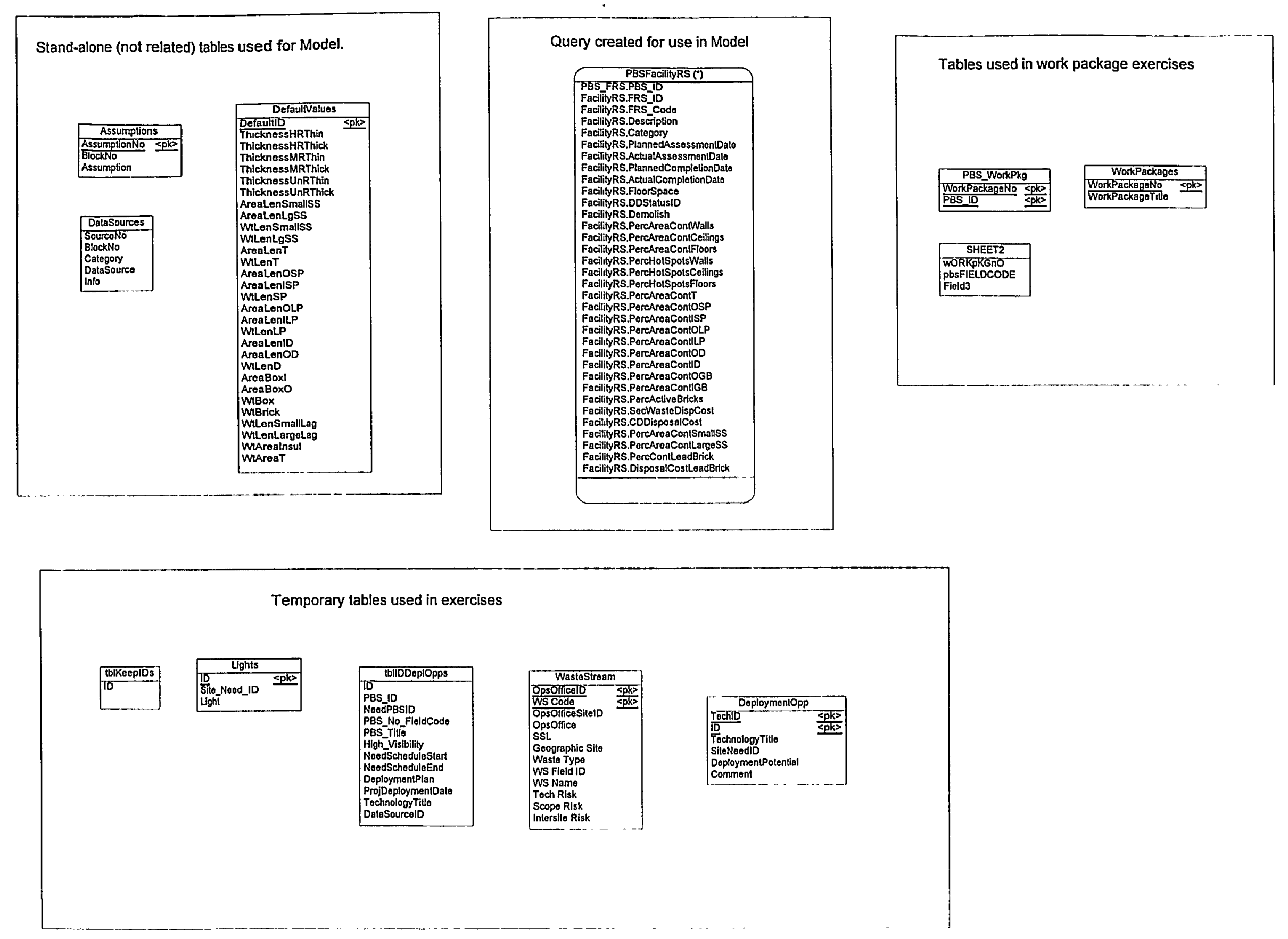
APPENDIX D

\section{COMPARISON OF MODEL EQUATIONS AND DATABASE VARIABLES}




\begin{tabular}{|c|c|c|c|}
\hline (m) & 1) ( & (1) & X \\
\hline \multicolumn{4}{|l|}{ DefaultValues Table } \\
\hline thickness HR Thin & ThicknessHRThin & m & $\begin{array}{l}\text { Average thickness of heavily reinforced concrete less than or } \\
\text { equal to } 6 " \text { thick. The default value is } 0.152 \mathrm{~m}\left(6^{\prime \prime}\right) \text {. }\end{array}$ \\
\hline thickness HR Thick & ThicknessHRThick & m & $\begin{array}{l}\text { Average thickness of heavily reinforced concrete greater than 6" } \\
\text { thick. The default value is } 0.305 \mathrm{~m}(12 ") \text {. }\end{array}$ \\
\hline thickness MR Thin & ThicknessMRThin & m & $\begin{array}{l}\text { Average thickness of moderately reinforced concrete less than or } \\
\text { equal to } 6^{\prime \prime} \text { thick. The default value is } 0.152 \mathrm{~m}\left(6^{\prime \prime}\right) \text {. }\end{array}$ \\
\hline thickness MR Thick & ThicknessMRThick & m & $\begin{array}{l}\text { Average thickness of moderately reinforced concrete greater than } \\
6^{\prime \prime} \text { thick. The default value is } 0.305 \mathrm{~m}\left(12^{\prime \prime}\right) \text {. }\end{array}$ \\
\hline thickness UnR Thin & ThicknessUnRThin & $m$ & $\begin{array}{l}\text { Average thickness of unreinforced concrete less than or equal to } \\
6 " \text { thick. The default value is } 0.152 \mathrm{~m}\left(6^{\prime \prime}\right) \text {. }\end{array}$ \\
\hline thickness UnR Thick & ThicknessUnRThick & m & $\begin{array}{l}\text { Average thickness of unreinforced concrete greater than } 6 \text { " thick. } \\
\text { The default value is } 0.305 \mathrm{~m}(12 ") \text {. }\end{array}$ \\
\hline area/length small ss & AreaLenSmallss & $\mathrm{sq}-\mathrm{m} / \mathrm{m}$ & $\begin{array}{l}\text { Average unit perimeter area for structural steel members less than } \\
\text { or equal to } 8 \text { " depth. The default value }(0.689) \text { is based on a } W \\
\text { shape } 1 \text {-beam, } 6 \text { " depth, } 4^{\prime \prime} \text { flange, designation } 6 \times 12 \text {. }\end{array}$ \\
\hline area/length large SS & AreaLenLgSS & $\mathrm{sq}-\mathrm{m} / \mathrm{m}$ & $\begin{array}{l}\text { Average unit perimeter area for structural steel members greater } \\
\text { than } 8^{\prime \prime} \text { depth. The default value }(1.39) \text { is based on a W shape I- } \\
\text { beam, } 12^{\prime \prime} \text { depth, } 8 \text { flange, designation } 12 \times 45 \text {. }\end{array}$ \\
\hline weight/length small SS & WtLenSmallss & $\mathrm{kg} / \mathrm{m}$ & $\begin{array}{l}\text { Average unit weight for structural steel members less than or } \\
\text { equal to } 8^{\prime \prime} \text { depth. The default value }(17.9) \text { is based on a } W \text { shape } \\
\text { I-beam, } 6 \text { " depth, } 4 \text { "flange, designation } 6 \times 12 \text {. }\end{array}$ \\
\hline weight/length large SS & WtLenLgSS & $\mathrm{kg} / \mathrm{m}$ & $\begin{array}{l}\text { Average unit weight for structural steel members greater than } 8 \text { " } \\
\text { depth. The default value }(67.0) \text { is based on a W shape l-beam, } \\
12^{\prime \prime} \text { depth, } 8 \text { " flange, designation } 12 \times 45 \text {. }\end{array}$ \\
\hline area/length $T$ & AreaLenT & $\mathrm{sq}-\mathrm{m} / \mathrm{m}$ & $\begin{array}{l}\text { Average outside unit area for instrument tubing. The default value } \\
(0.0199) \text { is based on } 1 / 4^{\prime \prime} \mathrm{OD}, 0.036^{\prime \prime} \text { wall thickness, stainless } \\
\text { steel tubing. }\end{array}$ \\
\hline weight/length $T$ & WtLenT & $\mathrm{kg} / \mathrm{m}$ & $\begin{array}{l}\text { Average unit weight for instrument tubing. The default value } \\
(0.147) \text { is based on } 1 / 4^{\prime \prime} O D, 0.036 \text { " wall thickness, stainless steel } \\
\text { tubing. }\end{array}$ \\
\hline area/length ISP & AreaLenISP & $s q-m / m$ & $\begin{array}{l}\text { Average outside unit area for small piping. The default value } \\
(0.321) \text { is based on } 4 \text { " schedule } 40 \text { steel pipe. }\end{array}$ \\
\hline area/length OSP & AreaLenOSP & $s q-m / m$ & $\begin{array}{l}\text { Average outside unit area for small piping. The default value } \\
(0.359) \text { is based on } 4 " \text { schedule } 40 \text { steel pipe. }\end{array}$ \\
\hline weight/length SP & WtLenSP & $\mathrm{kg} / \mathrm{m}$ & $\begin{array}{l}\text { Average unit weight for small piping. The default value (16.1) is } \\
\text { based on } 4 " \text { schedule } 40 \text { steel pipe. }\end{array}$ \\
\hline area/length ILP & AreaLenILP & $s q-m / m$ & $\begin{array}{l}\text { Average inside unit area for large piping. The default value (0. ) } \\
\text { is based on } 10^{\prime \prime} \text { schedule } 40 \text { steel pipe. }\end{array}$ \\
\hline
\end{tabular}




\begin{tabular}{|c|c|c|c|}
\hline WLL L & Dix & (1) & 1 \\
\hline area/length OLP & AreaLenOLP & $\mathrm{sq}-\mathrm{m} / \mathrm{m}$ & $\begin{array}{l}\text { Average outside unit area for large piping. The default value } \\
(0.858) \text { is based on } 10^{\prime \prime} \text { schedule } 40 \text { steel pipe. }\end{array}$ \\
\hline weight/length LP & WtLenLP & $\mathrm{kg} / \mathrm{m}$ & $\begin{array}{l}\text { Average unit weight for large piping. The default value }(60.3) \text { is } \\
\text { based on } 4 \text { " schedule } 40 \text { steel pipe. }\end{array}$ \\
\hline area/length ID & AreaLenID & $\mathrm{sq}-\mathrm{m} / \mathrm{m}$ & $\begin{array}{l}\text { Average inside unit area for ducts. The default value }(1.83) \text { is } \\
\text { based on ducts measuring } 18^{\prime \prime} \times 18^{\prime \prime} \text {. }\end{array}$ \\
\hline area/length $O D$ & AreaLenOD & $s q-m / m$ & $\begin{array}{l}\text { Average outside unit area for ducts. The default value }(1.83) \text { is } \\
\text { based on ducts measuring } 18^{\prime \prime} \times 18^{\prime \prime} \text {. }\end{array}$ \\
\hline weight/length $D$ & WtLenD & $\mathrm{kg} / \mathrm{m}$ & $\begin{array}{l}\text { Average unit weight for ducts. The default value }(23.8) \text { is based } \\
\text { on ducts measuring } 18^{\prime \prime} \times 18^{\prime \prime} \text { and constructed of } 16 \text { gage } \\
\text { galvanized sheet steel. }\end{array}$ \\
\hline area/box I & AreaBoxl & sq-m/box & $\begin{array}{l}\text { Average inside unit area for glove boxes. The default value (4.88) } \\
\text { is based on glove boxes measuring } 48^{\prime \prime} \text { wide } \times 30^{\prime \prime} \text { deep } \times 30^{\prime \prime} \\
\text { high. }\end{array}$ \\
\hline area/box 0 & AreaBoxO & $\mathrm{sq}-\mathrm{m} / \mathrm{box}$ & $\begin{array}{l}\text { Average outside unit area for glove boxes. The default value } \\
(4.88) \text { is based on glove boxes measuring } 48^{\prime \prime} \text { wide } \times 30^{\prime \prime} \text { deep } \times \\
30^{\prime \prime} \text { high. }\end{array}$ \\
\hline weight/box & WtBox & $\mathrm{kg} / \mathrm{box}$ & $\begin{array}{l}\text { Average unit weight for glove boxes. The default value }(91.3) \text { is } \\
\text { based on glove boxes measuring } 48^{\prime \prime} \text { wide } \times 30^{\prime \prime} \text { deep } \times 30^{\prime \prime} \text { high } \\
\text { and constructed of } 13 \text { gage flat rolled steel. }\end{array}$ \\
\hline weight/brick & WtBrick & $\mathrm{kg} / \mathrm{brick}$ & $\begin{array}{l}\text { Average weight of lead brick. The default value is based on brick } \\
\text { with dimensions of } 2^{\prime \prime} \times 4.5^{\prime \prime} \times 9^{\prime \prime} \text {. }\end{array}$ \\
\hline weight/length lagging SP & WtLenSmallLag & $\mathrm{kg} / \mathrm{m}$ & $\begin{array}{l}\text { Average unit weight for asbestos lagging for small pipes. The } \\
\text { default value is based on } 4 \text { " steel pipe with } 2^{\prime \prime} \text { thick insulation. }\end{array}$ \\
\hline weight/length lagging LP & WtLenLargeLag & $\mathrm{kg} / \mathrm{m}$ & $\begin{array}{l}\text { Average unit weight for asbestos lagging for large pipes. The } \\
\text { default value is based on } 10^{\prime \prime} \text { steel pipe with } 3^{\prime \prime} \text { thick insulation. }\end{array}$ \\
\hline weight/area insulation & WtArealnsul & $\mathrm{kg} / \mathrm{sq}-\mathrm{m}$ & $\begin{array}{l}\text { Average weight of asbestos insulation per square meter of } \\
\text { insulation. The default value is based on an insulation thickness } \\
\text { of } 3 " \text {. }\end{array}$ \\
\hline weight/area T & WtAreaT & $\mathrm{kg} / \mathrm{sq}-\mathrm{m}$ & $\begin{array}{l}\text { Unit weight of transite insulation. The default value is based on } \\
\text { transite panels with a thickness of } 1 / 2 " \text {. }\end{array}$ \\
\hline \multicolumn{4}{|l|}{ FacilityRS Table } \\
\hline Size & FloorSpace & sq-m & The total floor area for the specific facility. \\
\hline$\%$ area contaminated walls & PercAreaContWalls & $\%$ & The percent of the facility walls that are contaminated. \\
\hline$\%$ area contaminated ceilings & PercAreaContCeilings & $\%$ & The percent of the facility ceilings that are contaminated. \\
\hline \% area contaminated floors & PercAreaContFloors & $\%$ & The percent of the facility floors that are contaminated. \\
\hline sec. waste disposal cost & SecWasteDispCost & $\$ / \mathrm{kg}$ & Cost for on-site disposal of contanct handled (secondary) waste. \\
\hline
\end{tabular}




\begin{tabular}{|c|c|c|c|}
\hline 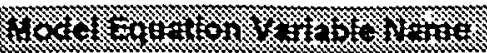 & (1) & 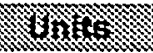 & How \\
\hline CD disposal cost & CDDisposalCost & $\$ / k g$ & Cost for on-site disposal of construction debris. \\
\hline$\%$ hot spots walls & PercHotSpotsWalls & $\%$ & The percent of hot spots in concrete walls. \\
\hline$\%$ hot spots ceilings & PerchotSpotsCeilings & $\%$ & The percent of hot spots in concrete ceilings. \\
\hline$\%$ hot spots floors & PercHotSpotsFloors & $\%$ & The percent of hot spots in concrete floors. \\
\hline$\%$ area contaminated small SS & PercAreaContSmallss & $\%$ & $\begin{array}{l}\text { The percent of the total small structural steel surface area that is } \\
\text { contaminated. }\end{array}$ \\
\hline$\%$ area contaminated large SS & PercAreaContLargess & $\%$ & $\begin{array}{l}\text { The percent of the total large structural steel surface area that is } \\
\text { contaminated. }\end{array}$ \\
\hline$\%$ area contaminated $T$ & PercAreaContT & $\%$ & $\begin{array}{l}\text { The percent of the total outside surface of all instrument tubing } \\
\text { that is contaminated. }\end{array}$ \\
\hline$\%$ area contaminated ISP & PercAreaContlSP & $\%$ & $\begin{array}{l}\text { The percent of the total inside surface of all small piping that is } \\
\text { contaminated. }\end{array}$ \\
\hline$\%$ area contaminated OSP & PercAreaContosP & $\%$ & $\begin{array}{l}\text { The percent of the total outside surface of all small piping that is } \\
\text { contaminated. }\end{array}$ \\
\hline$\%$ area contaminated ILP & PercAreaContILP & $\%$ & $\begin{array}{l}\text { The percent of the total inside surface of all large piping that is } \\
\text { contaminated. }\end{array}$ \\
\hline$\%$ area contaminated OLP & PercAreaContOLP & $\%$ & $\begin{array}{l}\text { The percent of the total outside surface of all large piping that is } \\
\text { contaminated. }\end{array}$ \\
\hline$\%$ area contaminated OD & PercAreaContOD & $\%$ & $\begin{array}{l}\text { The percent of the total outside surface of all ducting that is } \\
\text { contaminated. }\end{array}$ \\
\hline$\%$ area contaminated ID & PercAreaContiD & $\%$ & $\begin{array}{l}\text { The percent of the total inside surface of all ducting that is } \\
\text { contaminated. }\end{array}$ \\
\hline$\%$ area contaminated OGB & PercAreaContOGB & $\%$ & $\begin{array}{l}\text { The percent of the total outside surface of all glove boxes that are } \\
\text { contaminated. }\end{array}$ \\
\hline$\%$ area contaminated IGB & PercAreaContIGB & $\%$ & $\begin{array}{l}\text { The percent of the total inside surface of all glove boxes that are } \\
\text { contaminated. }\end{array}$ \\
\hline$\%$ lead bricks contaminated & PercContLeadBrick & $\%$ & The percent of all lead bricks that are rad contaminated \\
\hline$\%$ active bricks & PercActiveBricks & $\%$ & $\begin{array}{l}\text { The percent of all lead bricks that have become activated and can } \\
\text { not be decontaminated. }\end{array}$ \\
\hline disposal cost lead brick & DisposalCostLeadBrick & $\$ / k g$ & The cost for on-site disposal of decontaminated lead brick. \\
\hline $\begin{array}{l}\text { FacilityRSInorg Table } \\
\text { contaminant factor inorganic }\end{array}$ & ContFactlnorg & $\%$ & The percent of contaminated area inorganic contaminated \\
\hline transport cost inorganic & TransCostInorg & $\$ / k m-k g$ & $\begin{array}{l}\text { Unit cost for transportation of inorganic contaminated primary } \\
\text { waste to off-site disposal. }\end{array}$ \\
\hline distance inorganic & Distancelnorg & km & $\begin{array}{l}\text { Distance to transport inorganic contaminated primary waste for off } \\
\text { site disposal. }\end{array}$ \\
\hline
\end{tabular}




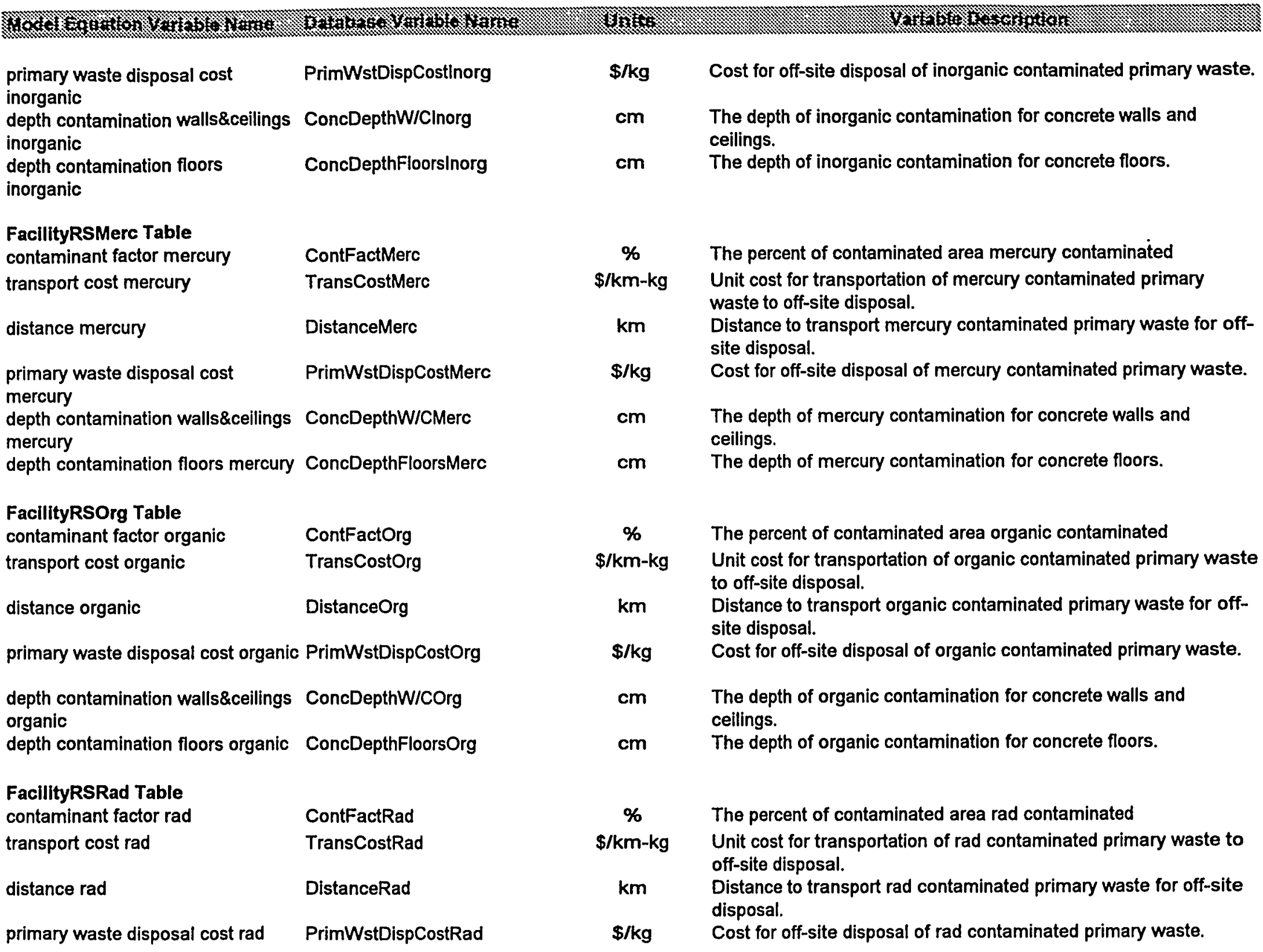




\begin{tabular}{|c|c|c|c|}
\hline 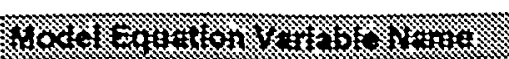 & (1) & Q & W \\
\hline $\begin{array}{l}\text { depth contamination walls\&ceilings } \\
\text { rad } \\
\text { depth contamination floors rad }\end{array}$ & ConcDepthW/CRad & $\mathrm{cm}$ & The depth of rad contamination for concrete walls and ceilings. \\
\hline \multicolumn{4}{|l|}{ FacillityType Table } \\
\hline Height & Height & m & Height for facility type. \\
\hline Wall Multiplier & WallMultiplier & & Number of corridors for facility type. \\
\hline Small Structural Steel Factor & SmallsSFactor & m & $\begin{array}{l}\text { Spacing between small strutural steel members. Small structural } \\
\text { steel are horizontal members that support ceiling. }\end{array}$ \\
\hline Large Structural Steel Factor & LgSSFactor & m & $\begin{array}{l}\text { Spacing between large structural steel members on two sides of } \\
\text { building. Large structural steel members are vertical beams. }\end{array}$ \\
\hline Tubing Factor & TubingFactor & $\mathrm{m} / \mathrm{sq}-\mathrm{m}$ & $\begin{array}{l}\text { Length of instrument tubing per square meter of floor area for } \\
\text { facility type. }\end{array}$ \\
\hline Small Pipe Factor & SPFactor & $\mathrm{m} / \mathrm{sq}-\mathrm{m}$ & $\begin{array}{l}\text { Length of piping less than or equal to nominal } 4 \text { " diameter, per } \\
\text { square meter of floor area for facility type. }\end{array}$ \\
\hline Large Pipe Factor & LPFactor & $\mathrm{m} / \mathrm{sq}-\mathrm{m}$ & $\begin{array}{l}\text { Length of piping greater than nominal } 4^{\prime \prime} \text { diameter, per square } \\
\text { meter of floor area for facility type. }\end{array}$ \\
\hline Ducting Factor & DFactor & $\mathrm{m} / \mathrm{sq}-\mathrm{m}$ & Length of ducting per square meter of floor area for facility type. \\
\hline Lead Brick Factor & BrickFactor & No. Bricks/sq-m & Number of bricks per square meter of floor area for facility type. \\
\hline Box Factor & BoxFactor & No. Boxes/sq-m & $\begin{array}{l}\text { Number of glove boxes per square meter of floor area for facility } \\
\text { type. }\end{array}$ \\
\hline Small Pipe Lagging Factor & SPLaggingFactor & $\mathrm{m} / \mathrm{m}$ & $\begin{array}{l}\text { Meters of small pipe asbestos lagging per meter of small pipe for } \\
\text { facility type. }\end{array}$ \\
\hline Large Pipe Lagging Factor & LPLaggingFactor & $\mathrm{m} / \mathrm{m}$ & $\begin{array}{l}\text { Meters of large pipe asbestos lagging per meter of large pipe for } \\
\text { facility type. }\end{array}$ \\
\hline Transite Factor & TransFactor & $s q-m / s q-m$ & $\begin{array}{l}\text { Area of transite insulation per square meter of floor area for facility } \\
\text { type. }\end{array}$ \\
\hline$\%$ area concrete wall & PercAreaConcreteWalls & $\%$ & percent of total wall area made of concrete. \\
\hline$\%$ area concrete floor & PercAreaConcreteFloors & $\%$ & percent of total floor area made of concrete. \\
\hline$\%$ area concrete ceiling & PercAreaConcreteCeilings & $\%$ & percent of ceiling area made of concrete. \\
\hline$\%$ area HR Thin wall & PercAreaHRThinWalls & $\%$ & $\begin{array}{l}\text { percent of concrete wall that is heavily reinforced and less than or } \\
\text { equal to 6" thick. }\end{array}$ \\
\hline$\%$ area HR Thick wall & PercAreaHRThickWalls & $\%$ & $\begin{array}{l}\text { percent of concrete wall that is heavily reinforced and greater than } \\
6 " \text { thick. }\end{array}$ \\
\hline$\%$ area MR Thin wall & PercAreaMRThinWalls & $\%$ & $\begin{array}{l}\text { percent of concrete wall that is moderately reinforced and less } \\
\text { than or equal to } 6 " \text { thick. }\end{array}$ \\
\hline
\end{tabular}




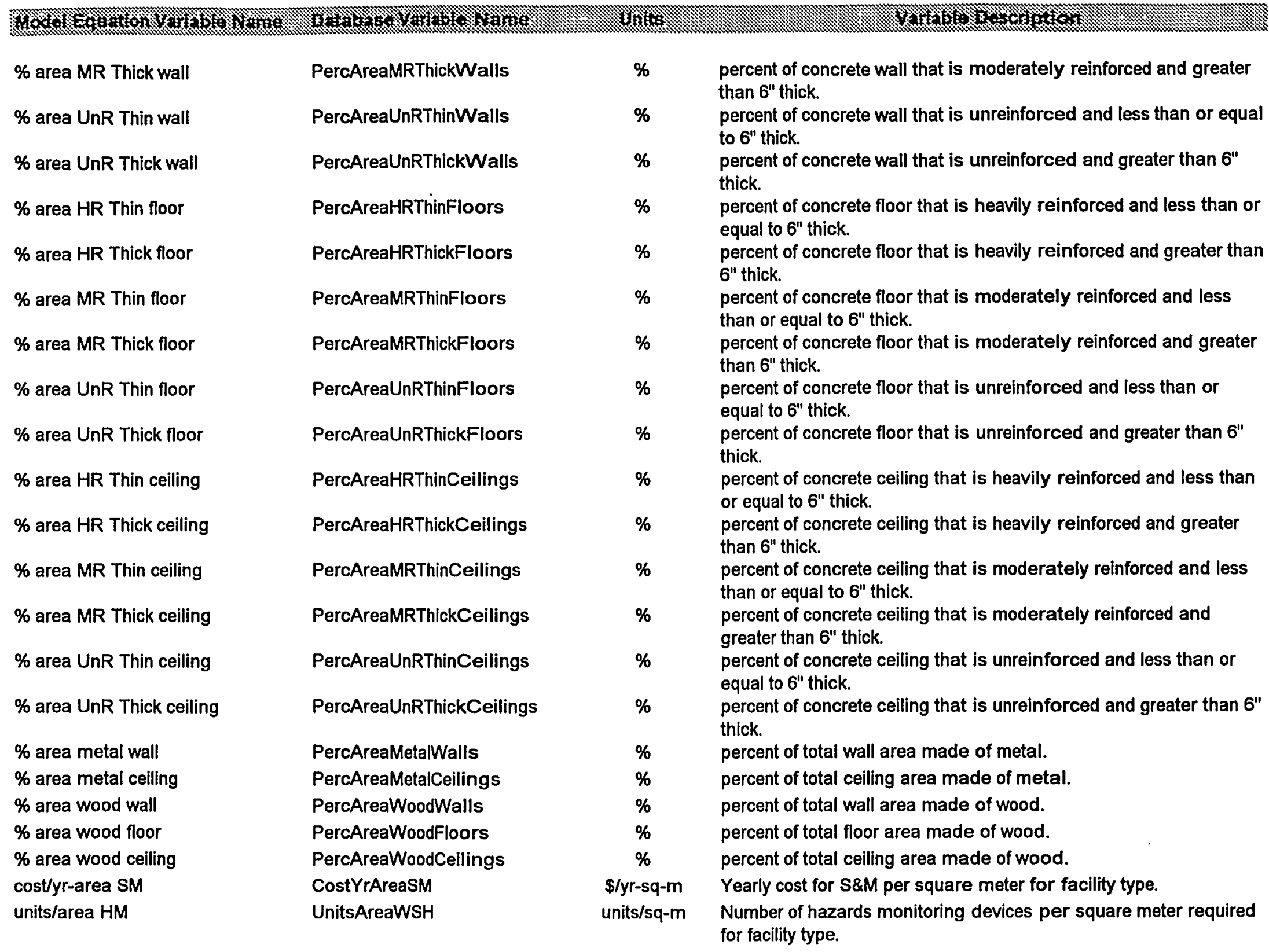




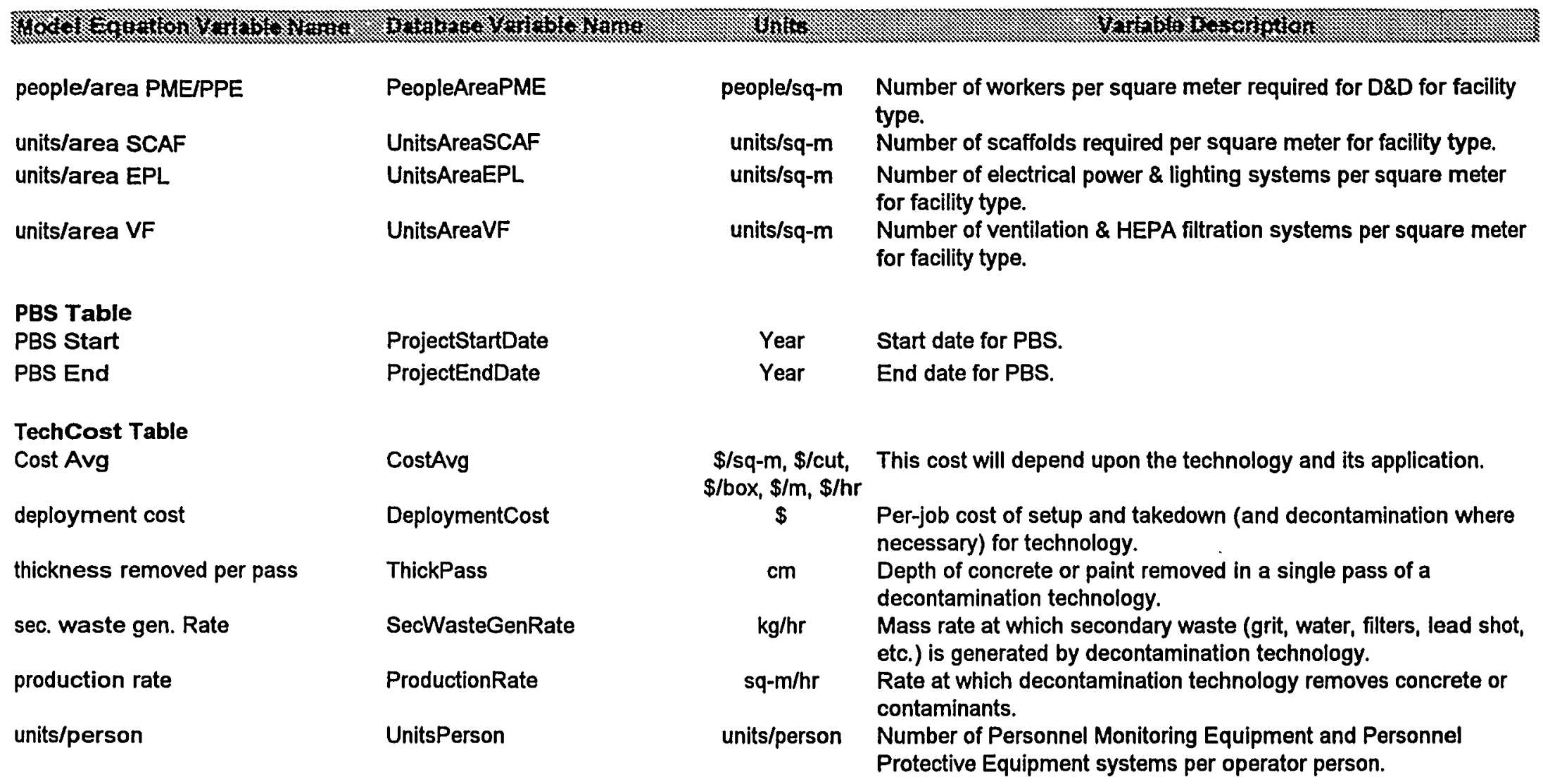

Variables in the DefaultValues DB Table are a function of the facility type. These variables are underlined in the D\&D Model Guidance. Variables in the FacilityType DB Table are a function of the facility type. These variables are underlined in the D\&D Model Guidance. Variables in the FacilityRS DB Table are a function of the specific facility. These variables are bolded in the D\&D Model Guidance. Variables in the FacilityRSInorg DB Table are a function of the specific facility. These variables are bolded in the D\&D Model Guidance. Variables in the FacilityRSMerc DB Table are a function of the specific facility. These variables are bolded in the D\&D Model Guidance. Variables in the FacilityRSOrg DB Table are a function of the specific facility. These variables are bolded in the D\&D Model Guidance. Variables in the FacilityRSRad DB Table are a function of the specific facility. These variables are bolded in the D\&D Model Guidance. Variables in the PBS DB Table are a function of the specific facility. These variables are bolded in the D\&D Model Guidance.

Variables in the TechCost DB Table are a function of the specific technology. These variables are italicized in the D\&D Model Guidance. 



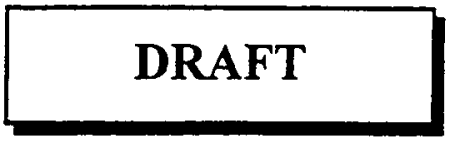

APPENDIX D

\section{A4. ASSUMPTIONS}


The following assumptions were made during the generation of the technology list

Description of Deployment (PDT) Codes used in Technology Evaluations

Level

CATEGORIES

Blank (Insufficient information/no applicable sub categories)

Code

o0 Decomissioning Categories

Other

Facility Construction

Decomissioning Residue

$\infty$

Material Types

Other

Concrete/Masonry/Brick

Metal

Wood

Asbestos/Transite

Solids/Debris

Sludge

Liquid

Process Types

Characterzzation

Decontamination

Cutting \& Sizing

Demolition

Material Disposition

Worker Safety \& Health

Remote Tooling/Automation

Treatment

03 Process Sub-Types

Characterization

Large/Complex Areas

Internal Charactenzation (pipes, ducts, process equip)

inaccessible Areas (confined space, behind walls, containers)

Structural integrity inspection

Buried Objects

??????

Concrete Decon Sub-Types

Floors

Walls \& Ceilings

01

02

Metal Decon Sub-Types

Lead Bricks

Equip/Glove Boxes/Dismantled Piping

Sheet Metal/Structural Steel/ Steel Liners

System Piping/Tank internals

Concrete Cutting \& Sizing Sub-Types

Heavily reinforced

Unreinforced

Walls \& Floors

Metal Cutting \& Sizing Sub-Types

Instrument Tubing

Large Diameter Piping

Small Diameter Piping

Flat Stock \& Pressure Vessels

Struetural Steel

Lead Bricks

Demolition Sub-Types

Reinforced

Lightly Reinforced

Non-Reinforced

Stack

Structure

Sheathing Intact

Sheathing Removed

Disposition Sub-Types

Handling

Sorting

Packaging

Recycle

Waste Minimization/Disposal

$\infty$

01

02

03

04

05

06

07

01

02

03

04

05

06

07

08

01

02

03

04 
Worker Safety \& Health Sub-Types

Hazards Monitoring/Control (Including Air Monitoring)

Porsonnel Monitoring Equipment $\quad 35$

$\begin{array}{ll}\text { Porsonnol Protective Equipment } & 36\end{array}$

Treatment Sub-Types

$\begin{array}{ll}\text { Organic Contaminants } & 37\end{array}$

Inorganic Contaminants $\quad 38$

$\begin{array}{lr}\text { Radioactivo Contaminants } & 39\end{array}$

$\begin{array}{lr}\text { Mixed LLW/Organic } & 40\end{array}$

$\begin{array}{ll}\text { Mixed LLW/Inorganic } & 41\end{array}$

$\begin{array}{lr}\text { Asbestos/Transite } & 42\end{array}$

Lead $\quad 43$

04 Condition Categories

$\begin{array}{ll}\text { Concrete Decon Categories } & 01 \\ \text { Largo Areas } & 02\end{array}$

Small Areas $\quad 02$

$\begin{array}{ll}\text { Metal Decon Categories (equip/glove boxes/dismantled piping) } & 02 \\ \text { Large Components } & 03\end{array}$

$\begin{array}{ll}\text { Small Components } & 04\end{array}$

Metal Decon Categories (sheet metal/structural steel. Stainless steel liners)
Floors

Walls \& Ceilings $\quad 06$

$\begin{array}{ll}\text { Metal Decon Categories (system piping/Tank Internals) } & 07 \\ \text { Stainiess \& High Alloy Steels (Reactor Systems) }\end{array}$

$\begin{array}{ll}\text { Carbon/Low Alloy Steels } & 08\end{array}$

$\begin{array}{ll}\text { Metal Cutting Categories } & 09 \\ \text { Thermal } & 9\end{array}$

$\begin{array}{ll}\text { Non-thermal } & 10\end{array}$

Characterization

$\begin{array}{ll}\text { Loose Contamination } & 11\end{array}$

12
13

o5 Condition Sub-Categories $\quad 13$

Decon Sub-Categories
Painted Surfaces

$\begin{array}{ll}\text { Depth }<1 / 32^{*} \quad \text { - } & 02 \\ \end{array}$

Depth 1/32" to $1 / 8^{*} \quad 03$

Depth $1 / 8^{\prime \prime}$ to $1 / 4^{*} \quad 04$

$\begin{array}{ll}\text { Depth }>=1 / 4^{*} & 05\end{array}$

$\begin{array}{ll}\text { Cracks/Crevices } & 06\end{array}$

\section{TMS LIST}

General Assumptions

1 Once a technology was identified from the Industry Partners program, only the data within TMS was entered

2 If a commercial point of contact was available it was used, if not, the Project Manager or Principal Investigator was used

3 If a technology was terminated and it is not commercially available it was removed from consideration. Note: There was at least one technology terminated that still became commercial.

4 All technologies within the TMS were assumed atternative

5 For TMS technologies, only those commercially available were considered available

6 If date of availability not available, entered the planned date for Gate 6

7 Some technologies list Gate 6 dates that have passed but the TMS data has not been updated

B The TMS listing includes all D\&D TMS technologies, Industry partners technologies, and any other LSDP

selected technologies

PDT Assumptions

9 Laser devices can only clean coatings on concrete or metal

10 Electrokinetic techniques will penetrate to depths greater than $1 / 4$ inch

11 If spaces are left blank (not including after area is complete) it is believed that the technology is too general to be put into one category or sufficient information is not present in the TMS

12 The POT codes are applied in a fairly broad manner to be more inclusive 
Where applicable, those entering this data have erred on putting in too many PDTs (stratching the knowledge) rather than the opposite

14 The PDT codes used do not fit all technologies, technologies were not forcad into an PDT, but rather the information was loft biank.

15 Some TMS "s contain multiple technologies, for this study they were considered a single technology.

16 Visually detectabie buildup inside a pipe was considered loose contamination

17 Fixed contamination consisted of contamination within the original coatings and surfaces.

18 Robot Task Space Handier: There is no description of this technology in the TMS

PAM LIST

1 Chemical leaching (Section 3.16.7 of Non-Thermal Treatment altematives) is not a single technology in the PAM but is a classification of technologies.

2 Chemical leaching technologies suitable for ex-situ treatment of solids/debris and sludge were taken from Section 3.1 Chemical Extraction of the Decontamination Alternatives. Best engineering judgement was used during the selection.

3 Chemical decontamination (Section 3.16.6 of Non-Themal Treatment alternatives) is not a single technology in the PAM but is a classification of technologies.

4 Chemical decontamination technologies suitable for ex-situ treatment of solids/debris were taken from Section 3.1 Chemical Extraction of the Decontamination Altematives. Best engineering judgement was used during the selection.

5 Grit/water blasting/steam technologies suitable for ex-situ treatment of solids/debris with asbestos or lead contaminants, or surface contamination, were taken from Section's 3.6 (Vacuuming/Blasting) and 3.7 (Washing) of the Decontamination Altematives. Best engineering judgement was used during the selection.

6 The singular Landfilis (Section 3.17.3 of Disposal altematives) was divided into four Landfill types (RCRA, TSCA, Radioactive, and Mixed) for this database.

7 The same chemical leaching technologies selected for ex-situ treatment of solids/debris with organic contaminants were selected for ex-situ treatment of solids/debris with mixed LLW (containing organic contaminants). It was presumed that the intent was to remove the hazardous component (organic) leaving a solids/debris LLW.

8 The same chemical leaching technologies selected for ex-situ treatment of solids/debris with inorganic contaminants were selected for ex-situ treatment of solids/debris with mixed LLW (containing inorganic contaminants). It was presumed that the intent was to remove the hazardous component (inorganic) leaving a solids/debris LLW.

9 The same chemical ieaching technologies selected for ex-situ treatment of solids/debris with radioactive contaminants were selected for ex-situ treatment of sludge with radioactive contaminants. However, the PAM descriptions of the chemical leaching technologies do not indicate applicability to anything but solid surfaces (concrete, metal, etc.)

10 Chemical leaching technologies not considered for ex-situ treatment of solids/debris were those in which the PAM indicated that main use of the technology was removal of crud or metal (mainly iron) oxides. There was no description of crud. It was presumed that removal of "nust" was not of interest for a D\&D activity. These technologies could be included if more detail is provided.

11 Regardless of the color of the box in the table, if the symbol in the box did not match that given in the legend above each table, it was not included within the acceptance criteria.

"Expansive Grout/Demolition Compounds" equivalent to "Expansive Grout"

"Backhoe Mounted Shears" equivalent to "Mobile Shears"

"Shot Blasting" equivalent to "Shot Blast Scabbling"

"Ultra-High Pressure Water" equivalent to "Ultra-High Pressure (UHP) Water Jet"

"Explosive Charge/Explosive Cutting" equivalent to "Explosive Cutting"

Table 4-1 lists only Chemical Foam. Treated as though Chemical Foam/Gel.

Table 4-5 lists Chemical Foam/Gel as two separate items. They had the same ratings and were therefore combined.

19 For Table 4-1, $\geq 1 / 8^{*}$ reported in category 05 as $04-1 / 8^{n}$ to $1 / 4^{\prime \prime}$; < 1/8" reported in category 05 as $03-1 / 32^{n}$ to $1 / 8^{*}$

20 For Table 4-6, '1/32" reported in category 05 as $03-1 / 32^{n}$ to $1 / 8^{n} ;<1 / 32^{n}$ reported in category 05 as $02-<1 / 32^{n}$

21 Category designations do not allow differentiation between 'Concrete Stack' and 'Brick/Cinder Block Stack' in Table 4-3.

22 Large area and Small area ratings can be different and are lost in category designations in Table 4-6.

23 No category 04 designation is assigned for 'Organic Deposits Containing U/TRU/FP' or 'Uranium Contamination in Table 4-7.

PHOENIX LIST

The Phoenix Database is totally deficient with regards to technology description and use. 
Altemative technologies, which typically listed a National Laboratory as the vendor in the Phoenix, were considered not available pending better information.

3 Classifications for tubing and pipe for development of PDT codes were assumed to be:
instrument tubing
small diameter piping
large diameter piping
$<1^{\prime \prime}$
$>8^{*}$

Where possibie, the tables in the PAMs data set were used as guidance for development of PDT codes.

5 The PDT codes for the safety and waste handling technologies ware constructed based on the technology titie, technology category, and material inclusions owing to the lack of any technology description.

Assumptions for technology applicability are provided below for the safety and waste handling technologies.

6 AMS Carbon Soil Auger- Sampling Equipment: not enough information

7 Analog Smart Portable: used for alpha and beta radiation. Assumed used for air monitoring (worker safoty and health) near and characterization of concrete/masonry/brick, metal, wood, asbestos/transite surfaces before and during facility $D \& / D$ and air monitoring near and characterization of solids/debris after D\&D. The Material TYpe designation of 00 rofers to air.

8 Barrel Monitor-BRC Waste Analyzer : used for gamma radiation. Because of large size, assumed used for surface characterization of barrels which may contain gamma emitting decommission residue such as solids/debris, sludge, or liquid.

9 Beta Air Monitor- AMS-4: used for beta radiation. Assumed not easily portable based on $110 \mathrm{~V}$ electrical requirement and size. Assumed used for monitoring air near and characterizing surface of large surface made of concrete/masonry/brick (wall, foor, or ceiling), metal (process equipment or piping), wood, asbestos/transite.

10 Bicron Micro Rem-Micro Rem: used for gamma radiation. Assumed used for air monitoring (worker safety and health) near and characterization of concrete/masonry/brick, metal, wood, asbestos/transite surfaces before and during facility D\&/D and air monitoring near and characterization of solids/debris anter D\&D. The Material Type designation of 00 refers to air.

11 Cadet Vaneaxial- Ventitation Unit: assumed unit used to remove contaminated air from work space during facility $D \& D$

12 Canberra Counting System- 2400: used for beta radiation. Assumed used for monitoring (worker safety and health) and characterization of sutfaces (concrete/masonry/brick, motal, wood, asbestos/transite) by analysis of smears taken before and during facility $D \& / D$ and characterization of smears from solids/debris after $D \& D$. The Material Type designation of 00 refers to air.

Compactor- C6R 6-90-200

Dry Waste Hydraulic Compactor - Stock

Floor Monitor: Not enough information

Gas Flow Proportional Probe- HP-100A: not enough information

Gas Flow Proportional Probe-HP-100B : not enough information

Generator: Assumed used to provide power for Facility Construction activities such as characterization, decontamination, cutting and sizing. demotition, material disposition, worker safety and health.

19 GM Survey Meter- E-120: emitted radiation unknown. Assumed used for air monitoring (worker safoty and health) near and characterization of concrete/masonry/brick, metal, wood, asbestos/transite surfaces before and during facility $D \& / D$ and air monitoring near and characterization of solids/debris after D\&D. The Material Type designation of 00 refers to air.

20 GM Survey Meter- E-140: emitted radiation unknown. Assumed used for air monitoring (worker satety and health) near and characterization of concrete/masonry/brick, metal, wood, asbestos/transite surfaces before and during facility D\&/D and air monitoring near and characterization of solids/debris after D\&D. The Material Type designation of 00 refers to air.

21 GM Survey Meter- E.520: emitted radiation unknown. Assumed used for air monitoring (worker safety and health) near and characterization of conerete/masonry/brick, metal, wood, asbestos/transite surfaces before and during facility $D \& / D$ and air monitoring near and characterization of solids/debris after D\&D. The Material Type designation of 00 refers to air.

22 Half Mask Silicone Respirator - A-S5500: Assumed used for personal protection during Facility Construction activities including Decontamination. Cutting and Sizing. Demolition, Material Disposition.

23 Hand Probe- HP-190A : used for low energy beta radiation. Assumed used for air monitoring (worker safety and health) near and characterization of concrete/masonry/brick, metal, wood, asbestos/transite surfaces before and dunng facility D\&/D and air monitoring near and characterzation of solids/debris after D\&D. The Material Type designation of 00 refers to air.

24 Hand Probe- HP-210AL : used for low energy beta radiation in low gamma background. Assumed used for air monitoring (worker safety and health) near and characterization of concrete/masonry/brick, matal, wood. asbestos/transite surfaces before and duting facility $D \& / D$ and ait monitoring near and characterization of solids/debris atter D\&D. The Material Type designation of 00 refers to air. 
Hand Probe- HP-210L : used for low energy beta radiation in gamma background. Assumed used for air monitoring (worker safety and health) near and characterization of concrete/masonry/brick, metal, wood, asbestos/transite surfaces before and during facility D\&/D and air monitoring near and characterization of solids/debris atter D\&D. The Material Type designation of 00 refers to air.

Hand Probo- HP-260 : beta sensitive for personnel, table tops, foors, equipment. Assumed used for air monitoring (worker safery and health) near and characterization of concrete/masonry/brick. motal. wood. asbestos/transite surfaces bufore and during facility $D \& / D$ and air monitoring near and characterization of solids/debris ater D\&D. The Material Type dosignation of 00 refers to air.

Hand Probe- HP-270 : used for gamma radiation. Assumed used for air monitoring (worker safety and health) near and characterization of concrete/masonry/brick, metal, wood, asbestos/transite surfaces before and during facility D\&/D and air monitoring near and characterization of solids/debris after D\&D. The Material Type designation of $D O$ refers to air.

Hand Probo- LEG-1: low onergy gamma probe for 1-125. Assumod used for air monitoring (worker safoty and health) near and characterization of concrete/masonry/brick. metal, wood, asbestos/transite surfaces before and during facility $D \& / D$ and air monitoring near and characterization of solids/debris after D\&D. The Material Type designation of 00 refers to air.

29 Hepa-Vacuum- Several Models: Assumed used for removing contaminants (fine powders and entrained liquids) from air during ventilation of Facility Construction area undergoing Decontamination, Cutting Sizing. Demolition activities.

30 High Range Survey System- R0-7: emitted radiation unknown. Assumed used for air monitoring (worker safety and health) near and characterization of conerete/masonry/brick, metal, wood, asbestos/transite surfaces before and dunng facility D\&/D and air monitoring near and characterization of solids/debris atter D\&D. The Material Type designation of 00 refers to air.

31 HighTemp Vacuum Distillation of Pu Salt: Not enough information. Unsure whether to consider this Treatment (unknown contaminant) of a Decommissioning Residue or Material Disposition for Waste Minimization/Disposal of a Decommissioning Residue. The material type 00 refers to Pu salt. HPGe Waste Barrel Analyzer- Barrel Monitor: used for gamma radiation. Because of large size, assumed used for surface characterization of bartels which may contain gamma emitting decommissiong residue such as solids/debris, sludge, or liquid.

33 In Situ Secondary lon-Mass Spectrometry: Not enough information. Assumod applicablo to Facility Construction and Decommissioning Residue material types alike. Phoenix has technology in safety category. Thus technology assumed for Worker Satety and Health (process type) with Hazards Monitoring/Control as subtype.

lonization Chamber- RO-2: used for beta and gamma radiation. Assumed used for air monitoring (worker safety and health) near and characterization of concrete/masonary/brick, metal, wood, asbestos/transite surtaces before and during facility $D \& / D$ and air monitoring near and characterization of solids/debris ater D\&D. The Material Type designation of 00 refers to air. Jetair Model-3- Ventilation Unit: assumed unit used to remove contaminated air from work space during facility D\&D. Jetair Model-9-Ventilation Unit: assumed unit used to remove contaminated air from work space during facility D\&D. Light Aided Technologies: Not enough information. Mini Scaler- MS-2: Not enough information.

39 Miniature-Sized, Real-Time Radiation Detector: Not enough information. Assumed used for air monitoring (worker safety and health) near and characterization of concrete/masonary/brick, metal, wood, asbestos/transite surfaces before and during facility $D \& / D$ and air monitoring near and characterization of solids/debris anter D\&D. The Material Type designation of 00 refers to air. Mobile Cart Air Sampler- MRV-0523CV: 850

Mobile Office-MO208: This does not seem to be a D\&D specific technology.

Mobile Radiation Detection \& Mapping System- Insitu Soil Assay System: Assumed system used for Hazards Monitoring/Control relative to Worker Safety \& Health, and used for characterization of soils (and possibly buried objects) in-situ.

43 Personal Air Sampler - 08-430: Assumed system is used to check air (I.e.Hazards Monitoring/Control relative to Worker Safety \& Health) inside structure or large equipment prior to entrance by worker engaged in Facility Construction D\&D activity.

44 Plasma-Mass Spectrometry - ICP-MS: Not enough information.

45 Portable Generator- Wacker $G$ 2.5A: Assumed that the generator is considered a remote tooling/automation technology than can be used for any Facility Construction D\&D activity where power is required to operate Charactenzation, Decontamination, Cutting \& Sizing. Demolition, Materials Disposition, Worker Safety \& Health equipment.

46 Portable Generator-Wacker G 3.7A: Assumed that the generator is considered a remote tooling/automation technology than can be used for any Facility Construction D\&D activity where power is required to operate Characterization, Decontamınation, Cutting \& Sizing. Demolition, Materials Disposition. Worker Safety \& Health equipment.

47 Portable Generator- Wacker G 5.6A: Assumed that the generator is considered a remote tooling/automation technology than can be used for any Facility Construction D\&D activity where power is required to operate Charactenzation. Decontaminatıon. Cuttıng \& Sizing. Demolition. Materials Disposition, Worker Safety \& Health equipment. 
Portable Generator- Wacker GS 5.6A: Assumed that the generator is considered a remoto tooling/automation tochnology than can be used for any Facility Construction D\&D activity where power is required to operate Characterization, Decontamination, Cutting \& Sizing. Demolition, Materials Disposition, Worker Safety \& Health equipment.

49 Portable Lead Anahyzer- Pb Anahyzer: used for paint, wood, surface dust, soil, air fitters, smears. Assumed used to analyze for lead (as loose or fixed contaminant) on any painted surface (concrete, metal, wood) or on any solid/debris (soil, air filters, smears).generated by D\&D activities.

50 Portablo LIN-LOG Gas Proportional Alpha Counter- PAC-4G-3: used for alpha radiation. Assumed used for air monitoring (worker safety and health) near and characterization of conerete/masonary/brick, metal, wood. asbestos/transite surfaces before and during facility $D \& / D$ and air monitoring near and characterization of solids/debris after D\&D. The Material Type designation of 00 refers to air.

51 Portable lon Chamber- PIC-68: used for gamma radiation. Assumed used for air monitoring (worker safety and health) near and characterization of conerete/masonary/brick. metal, wood, asbestos/transite surfaces before and during facility D\&/D and air monitoring near and characterization of solids/debris after D\&D. The Materia! Type designation of 00 refers to air.

52 Portable Micro "R" Moter - ASP-1/SPA-8: used for gamma radiation. Assumed used for air monitoring (worker safety and health) near and characterization of concrete/masonary/brick, metal, wood, asbestos/transite surfaces before and during facility D\&/D and air monitoring neat and characterization of solids/debris after D\&D. The Material Type designation of 00 refers to air.

53 Portable Neutron rem Counter- ASP-1/NRD: used for neutron detection. Assumed used for air monitoring (worker safety and health) near and characterization of conerete/masonary/brick, metal, wood, asbestos/transite surfaces before and during faeility $D \& / D$ and air monitoring near and characterization of solids/debris after D\&D. The Material Type designation of 00 refers to air.

54 Portable Photometer - TDA-2G: unknown emitted radiation. Assumed used for air monitoring (worker safety and health) near and characterization of concrete/masonary/brick, metal, wood, asbestos/transite surfaces before and during facility D\&/D and air monitoring near and characterization of solids/debris after D\&D. The Material Type designation of 00 refers to air.

55 Portable Ventilation System - NARED: assumed unit used to remove contaminated air from work space during facility D\&D.

56 Radiation Monitor- RM-14S: unknown emitted radiation. Assumed used for air monitoring (worker safety and health) near and characterization of concrete/masonary/brick. metal, wood, asbestos/transite surfaces before and during facility D\&/D and air monitoring near and characterization of solids/debris atter D\&D. The Material Type designation of 00 refers to air.

57 Radiation Monitor- RM-20: unknown emitted radiation. Assumed used for air monitoring (worker safety and health) near and characterization of concrete/masonary/brick, metal, wood, asbestos/transite surfaces before and during facility $D \& / D$ and air monitoring neat and characterization of solids/debris atter D\&D. The Material Type designation of 00 refers to air.

58 Radiation Monitor- RM-21: unknown emitted radiation. Assumed used for air monitoring (worker safety and health) near and characterization of concrete/masonary/brick, metal, wood, asbestos/transite surfaces before and during facility $D \& / D$ and air monitoring neat and characterization of solids/debris atter D\&D. The Material Type designation of 00 relers to air.

59 Radon Gas Meter - TN-Rn2000: used for radon; limited to air, soil, and watet applications. Assumed used for alr monitoring (worker safety and health) and characterization (air inside large areas) relative to Facility Construction activities and Decommissioning residues, and used for characterization of Decommissioning residues (solids/debris, sludge, liquid).

60 Radon WL Meter - TN-WL-02: used for radon; limited to inside buildings. Assumed used for air monitoring (worker safety and health) and characterization (air inside large areas) relative to Facility Construction activities.

61 Removing Plutonium from Waste Streams: no information in Phoenix. Assumed waste stream is a Decommissiong Residue and can be solids/debris, sludge, liquid. Treatment is required to remove radioactive contaminant (plutonium).

62 Rotary Vane Low Volume Air Sampler- VS23-0523CV: unknown contaminants of interest. Assumed can be used for Characterization of air in Large/complex area or for Worker Safety \& Health Hazards Monitoring/Control during Facility Construction D\&D.

63 Sampling Equipment- AMS 4130: not enough information.

64 Sampling Equipment- B-460.00: not enough information.

65 Scintillation Probe - SPA-8: not enough information: Assumed used for hazards monitoring in areas in which personnel will be working

66 Separation of HTO Using Membranes and Tritium Membrane Test

67 Shredder. Industrial Model : used for wood and serap wood

68 Shredder- Mobile : used for steel, glass, concrete

69 Smart Portable- ESP.1: unknown emitted radiation. Assumed used for arr monitoring (worker safety and health) near and characterization of conerete/masonary/bnck, metal, wood, asbestos/transite surfaces before and during facility D\&ID and air monitoring near and characterzation of solids/debris after D\&D. The Materia! Type designation of 00 refers to air.

70 Smart Portable- ESP-2: unknown emitted radiation. Assumed used for air monitonng (worker safety and health) near and characterization of conerete/masonary/brick, metal, wood, asbestos/transite surfaces before and durng facility $D \& / D$ and air monitoring near and characterization of solids/debris after D\&D. The Material Type designation of 00 refers to air. 
72 Tritium Contamination Monitor - 05-667: Assumed used for air monitoring (worker safety and health) near and characterization of concrete/masonary/brick, metal, wood, asbestos/transite surfaces before and during facility D\&/D and air monitoring neat and characterization of solids/debris after D\&D. The Material Type designation of 00 refers to air.

73 TRUelean Soil Decon System - TRUelean: Assumed technology used for treatment of soil (solids/debris, sludge) to removed TRU contaminants.

74 Vehicle Monitor-Remote w/ 2 Pyion Detectors-501A-5RP : not enough information.

75 Ventilation Unit- MAC-21 P/N FM37: assumed unit used to remove contaminated air from work space during facility $D \& D$.

76 Ventilation Unit- PFX-1400A : assumed unit used to remove contaminated air trom work space during facility D\&D.

77 Ventilation Unit- Portaive Model- 4/6: assumed unit used to remove contaminated air from work space during facility D\&D.

78 Waste Compactors- MPC-60 : Unit assumed used for disposal of decommissioning residue

79 Water Soluble Polymers for Actinide Removal: not enough information. 


\section{COST AND SECONDARY WASTE INFORMATION}




\begin{tabular}{|c|c|c|c|c|c|c|}
\hline 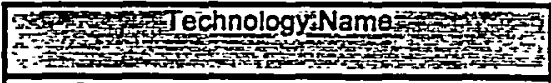 & TechlD & $\begin{array}{l}\text { Altemativel? } \\
\text { A Baselinie } \\
\cdots\end{array}$ & Tiotalpeployment & gVanables & Units & 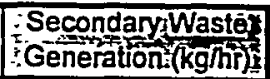 \\
\hline Pipe Explorer & 4 & $\bar{A}$ & 15592.00 & 188.87 & $\$ / s q-m$ & \\
\hline Steam Vacuum Cleaning & 27 & $\mathrm{~A}$ & 6895.00 & 16.50 & $\$ / s q \cdot m$ & 200 \\
\hline $\begin{array}{l}\text { Gamma-Ray Imaging System (PSC/BNFL } \\
\text { RadScan 600) }\end{array}$ & 31 & $\bar{A}$ & 14926.00 & 11.16 & \$/sq-m & \\
\hline MITUS & 32 & $\mathrm{~A}$ & 61656.00 & 108.00 & $S / h r$ & \\
\hline $\begin{array}{l}\text { Mobile Automated Characterization } \\
\text { System (Alpha-Beta) }\end{array}$ & 34 & $\bar{A}$ & 3037.00 & 9.55 & $\$ / s q-m$ & \\
\hline High-Speed Clamshell Pipe Cutter & 36 & $\bar{A}$ & 15881.00 & 1113.00 & S/cut & \\
\hline Pipe Crawler & 37 & A & 14764.00 & 321.73 & s/sq-m & \\
\hline Rotary Peening with Captive Shot & 39 & $\bar{A}$ & $1,672.00$ & 53.20 & \$/sq-m & 4.85 \\
\hline Gamma Cam & 42 & $A$ & $18,804.00$ & 52.00 & $s / s q-m$ & \\
\hline Centrifugal Shot Blast System & 45 & A & 17.840 .00 & 30.90 & s/sq-m & 16.9 \\
\hline $\begin{array}{l}\text { Position-Sensitive Radiation Monitoring } \\
\text { (Surface Contamination Monitor) }\end{array}$ & 52 & A & $12,282.00$ & 7.73 & $\$ / s q-m$ & \\
\hline $\begin{array}{l}\text { ROTO PEEN Scaler and VAC-PAC } \\
\text { System }\end{array}$ & $\overline{53}$ & $\bar{A}$ & $2,393.00$ & 55.50 & $\$ / s q-m$ & 3.83 \\
\hline Self-Contained Pipe Cutting Shear & 57 & A & 834.01 & 10.56 & S/cut & \\
\hline Concrete Shaver & 58 & A & $3,135.00$ & 24.30 & $\$ / s q-m$ & \\
\hline Advanced Recyclable Media & 61 & $\bar{A}$ & $1,768.00$ & 143.00 & $\$ / s q-m$ & 1.42 \\
\hline Laser Induced Fluoresence & 62 & A & 304.80 & 1.65 & $\$ / s q-m$ & \\
\hline In-Situ Object Counting System & 63 & $\bar{A}$ & 571.00 & 10.20 & $\$ / s q-m$ & \\
\hline Remotely Operated Scabbling Technology & 64 & $A$ & $10,948.00$ & 46.80 & \$sq-m & 2.89 \\
\hline $\begin{array}{l}\text { Remote Controlled Concrete Demolition } \\
\text { System }\end{array}$ & 65 & $\bar{A}$ & $11,587.00$ & 105.00 & $s / s q-m$ & \\
\hline Pavement Breaker & 102 & $B$ & 565.00 & $1,640.00$ & $\$ / s q-m$ & \\
\hline Piston Scabbler & 103 & $B$ & $3,209.00$ & 84.10 & S/sq-m & \\
\hline Circular Cutting Saw & 128 & B & 401.93 & 9.95 & s/sq-m & \\
\hline Diamond Wire & 129 & $B$ & $2,039.00$ & 88.60 & s/sq-m & \\
\hline Oxyacetylene Torch & 143 & $B$ & $3,962.00$ & 896.00 & \$/cut & \\
\hline Porta Band Bandsaw & 206 & $B$ & 246.00 & 16.60 & \$/cut & \\
\hline German Hacksaw & 207 & $B$ & 246.00 & 31.39 & \$/cut & \\
\hline Mechanical Scabbling & 245 & $B$ & $2,597.00$ & 116.00 & $\$ / s q-m$ & 5.45 \\
\hline Scaler & 302 & $B$ & $2,034.00$ & 310.00 & s/sq-m & \\
\hline Scabbler & 381 & $B$ & 2.093 .00 & 311.00 & $\$ / s q-m$ & \\
\hline Concrete Grinder & 519 & $\bar{A}$ & $2,014.00$ & 118.00 & $\$ / s q-m$ & \\
\hline Concrete Spaller & 520 & $\mathrm{~A}$ & 867.00 & 326.00 & $\$ / s q-m$ & \\
\hline $\begin{array}{l}\text { Liquid Nitrogen Cooled Diamond-Wire } \\
\text { Concrete Cutting }\end{array}$ & 521 & $\bar{A}$ & $7,107.00$ & 126.66 & $\$ / s q-m$ & \\
\hline High Pressure Water Cleaning & 523 & $\mathrm{~B}$ & $2,417.00$ & 20.50 & $\$ / s q-m$ & 490 \\
\hline Manual Alpha-Beta (FM-4G) & 524 & $B$ & 208.00 & 6.40 & $\$ / s q-m$ & \\
\hline Manual Alpha-Beta (Electra NE) & 525 & B & 208.00 & 6.84 & $s / s q-m$ & \\
\hline Coring/Off-site Analysis & 526 & B & 238.00 & 18.10 & $\$ / s q-m$ & \\
\hline Manual Gamma (Eberline RO-7) & 527 & $\mathrm{~B}$ & $3,297.00$ & 153.00 & $\$ / s q-m$ & \\
\hline Hydraulic Shear & 528 & $B$ & 605.00 & 18.44 & S/cut & \\
\hline Manual Radiologic Survey & 530 & $\mathrm{~B}$ & 918.00 & 2.14 & s/sq-m & \\
\hline Hand Held Floor Contamination Monitor & 532 & $\mathrm{~B}$ & $1,356.00$ & 16.97 & $\$ / s q-m$ & \\
\hline Portable Generater & 535 & $B$ & $82,179.00$ & 149.48 & $\$ / \mathrm{hr}$ & \\
\hline Restore Existing Plant Electrical System & 536 & $\mathrm{~B}$ & $329,399.00$ & 65.25 & $\$ / \mathrm{hr}$ & \\
\hline Hand-Held Frisker /w Swipes & 537 & $B$ & 0.00 & 17.90 & $\$ / s q-m$ & \\
\hline
\end{tabular}

